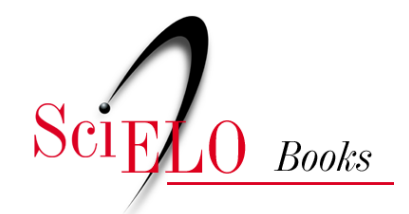

\title{
Literatura, leitura e educação
}

\author{
Márcia Cabral da Silva \\ Estela Natalina Mantovani Bertoletti \\ (orgs.)
}

SILVA, M.C., and BERTOLETTI, E.N.M., orgs. Literatura, leitura e educação (online). Rio de Janeiro: EDUERJ, 2017, 284 p. Pesquisa em educação/ Práticas de leitura e escrita series. ISBN 97885-7511-497-1. Available from: doi: 10.7476/9788575114971. Also available in ePUB from: http://books.scielo.org/id/5gg44/epub/silva-9788575114971.epub

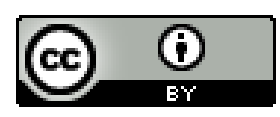

All the contents of this work, except where otherwise noted, is licensed under a Creative Commons Attribution 4.0 International license.

Todo o conteúdo deste trabalho, exceto quando houver ressalva, é publicado sob a licença Creative Commons Atribição $\underline{4.0}$.

Todo el contenido de esta obra, excepto donde se indique lo contrario, está bajo licencia de la licencia $\underline{\text { Creative Commons }}$ $\underline{\text { Reconocimento } 4.0 .}$. 


\section{Literatura, leitura e educação}


UNIVERSIDADE DO ESTADO DO RIO DE JANEIRO

Reitor

Ruy Garcia Marques

Vice-reitora

Maria Georgina Muniz Washington

\title{
ed 商 Conselho Editorial \\ uer)
}

Glaucio José Marafon (presidente)

Henriqueta do Coutto Prado Valladares

Hilda Maria Montes Ribeiro de Souza

Italo Moriconi Junior

José Ricardo Ferreira Cunha

Lucia Maria Bastos Pereira das Neves

Luciano Rodrigues Ornelas de Lima

Maria Cristina Cardoso Ribas

Tania Maria Tavares Bessone da Cruz Ferreira

Anibal Francisco Alves Bragança (EDUFF)

Katia Regina Cervantes Dias (UFRJ)

\section{Conselho Editorial da Série}

\author{
Alice Casimiro Lopes (UERJ) \\ Dario Fiorentini (Unicamp) \\ José Gonçalves Gondra (UERJ) \\ Maria Isabel da Cunha (Unisinos) \\ Zaia Brandão (PUC-Rio)
}




\author{
ORGANiZAÇÃo \\ Márcia Cabral da Silva \\ Estela Natalina Mantovani Bertoletti
}

\title{
Literatura, leitura \\ e educação
}

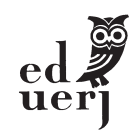

Rio de Janeiro, 2017 
Copyright $@$ C 2017, dos autores.

Todos os direitos desta edição reservados à Editora da Universidade do Estado do Rio de Janeiro. É proibida a duplicação ou reproduçấo deste volume, ou de parte do mesmo, em quaisquer meios, sem autorização expressa da editora.

Editor Executivo

Coordenadora Administrativa

Coordenadora Editorial

Assistente Editorial

Coordenador de Produção

Supervisor de Revisão

Revisão

Capa

Projeto gráfico e Diagramação
Glaucio Marafon

Elisete Cantuária

Silvia Nóbrega

Thiago Braz

Mauro Siqueira

Elmar Aquino

Shirley Lima

Júlio Nogueira

Editora Autografia

\section{CATALOGAÇÃO NA FONTE}

UERJ/REDE SIRIUS/NPROTEC

L776 Literatura, leitura e educação / organização Márcia Cabral da Silva, Estela Natalina Mantovani Bertoletti. - Rio de Janeiro : EdUERJ, 2017. $288 \mathrm{p}$.

ISBN 978-85-7511-458-2

1. Livros e leitura para crianças. 2. Educação. 3. Literatura. I. Silva, Márcia Cabral da. II. Bertoletti, Estela Natalina Mantovani.

CDU $028.5+37$

Bibliotecária: Regina Andrade CRB7/4051 


\section{Sumário}

Apresentaçáo

Márcia Cabral da Silva e Estela Natalina Mantovani Bertoletti

I. Produçáo acadêmica brasileira sobre literatura infantil (I970-2016): desafios de um campo em constituiçáo

Maria do Rosário Longo Mortatti e Fernando Rodrigues de Oliveira

2. Literatura infantil brasileira: conceitos e problemas

à luz dos estudos de Leonardo Arroyo e Cecília Meireles

MÁRCIA CABRAL DA SILVA

3. Literatura manuscrita nas leituras para a infância brasileira (I901-1955) ...73

ESTELA NATALINA MANTOVANI BERTOLETTI

4. O Tico-Tico: espaço de entretenimento e representaçáo da prática escolar republicana

Aline Santos Costa e Cíntia Borges de Almeida

5. Estória do galo e do Candimba, de Leonardo Arroyo (1961):

contradiçóes e renovaçáo na literatura infantil brasileira

VIVIANNY BESSÃO DE ASSIS

6. "Literatura em minha casa”: a seleçáo de livros para crianças

CÉlIA Regina Delácio Fernandes e FLÁVIA FERREIRA de PAULA

7. Literatura juvenil brasileira: espaço e representaçáo social em acervo do PNBE

MIRIAN HISAE YAEGASHI ZAPPONE

8. Infância e literatura: entre conceitos, palavras e imagens 
9. Leituras literárias em grupo: experiências, desafios e objetivos

NEIDE LuZIA DE REZENDE E GABRIELA RodeLla DE OLIVEIRA

Io. Por uma poesia para a infância

NINFA PARREIRAS

Sobre os autores.

$28 \mathrm{I}$ 
Tecendo a manhã

Um galo sozinho não tece uma manhã:

ele precisará sempre de outros galos.

De um que apanhe esse grito que ele

e o lance a outro; de um outro galo que apanhe o grito de um galo antes

e o lance a outro; e de outros galos

que com muitos outros galos se cruzem os fios de sol de seus gritos de galo [...]

João Cabral de Melo Neto 


\title{
Apresentação
}

\author{
Márcia Cabral da Silva \\ Estela Natalina Mantovani Bertoletti
}

Os textos aqui reunidos têm origem em um dossiê organizado para a revista Teias em 20I5, ${ }^{\mathrm{I}}$ com o eixo central em torno de três temáticas básicas: literatura, infância e educação. Em virtude do profícuo debate desenvolvido naquele momento, as organizadoras optaram por manter o mesmo eixo nesta publicação, associando-o, contudo, às discussóes contemporâneas acerca da leitura literária na escola, assim como à formação de professores, mediadores fundamentais na relação entre literatura, leitura e leitor.

Trata-se, portanto, de um investimento de pesquisadores cujo objeto de estudo tem sido a literatura destinada à infância e ao jovem, assim como as práticas de leitura no âmbito da escola e da vida social. Como é possível o leitor constatar, reuniu-se uma mostra representativa de pesquisas nas interfaces dos estudos de literatura e leitura, fruto da interlocução entre grupos de pesquisa consolidados em diferentes instituiçôes brasileiras de ensino público, como, por exemplo, o Grupo de Pesquisa História do Ensino de Língua e Literatura no Brasil (GPHELLB) - Unesp, o Grupo de Pesquisa Infância Juventude, Leitura, Escrita e Educação (GRUPEEL) - UERJ, o grupo de pesquisa Centro de Estudos em Ensino, Leitura, Literatura e Escrita (CEELLE) - UFGD,

I Revista Teias, v. I6, n. 40, 20I5, Proped - UERJ. Disponível em http://www.periodicos. proped.pro. 
o Grupo de Estudos e Pesquisas em História e Historiografia da Educação Brasileira (GEPHEB) - UEMS, o grupo de pesquisa Linguagens na Educação, da Faculdade de Educação da USP e grupo de pesquisa Infância, Linguagem e Escola - UFRJ. Tal interlocução pôde ser ampliada em múltiplas perspectivas que resultaram na consecução desta obra: o debate frequente em fóruns acadêmicos, a formação de professores, a orientação acadêmica e os resultados do estágio de pós-doutoramento.

Ao longo dos anos, as reflexóes reconfiguradas para este livro dizem respeito à produção de docentes e pesquisadores das seguintes universidades: Universidade Estadual Paulista (Unesp), Universidade Federal de São Paulo (Unifesp), Universidade do Estado do Rio de Janeiro (UERJ), Universidade Estadual de Mato Grosso do Sul (UEMS), Universidade Federal de Mato Grosso do Sul (UFMS), Universidade Federal da Grande Dourados (UFGD), Universidade Federal de Minas Gerais (UFMG), Universidade Estadual de Maringá (UEM), Universidade Federal do Rio de Janeiro (UFRJ), Universidade de São Paulo (USP) e Universidade Federal do Sul da Bahia (UFSB).

A relação da criança com o livro de ficção tem conhecido um percurso híbrido na historiografia da literatura infantil brasileira. Nas primeiras décadas do período republicano, por exemplo, houve um incremento considerável na produção, como resultado das políticas de alfabetização nos meios urbanos. No entanto, com frequência, os livros de poesia e de contos eram pensados para leitura na escola, em complemento aos programas curriculares.

Nos capítulos que se seguem, embora sem a pretensão de cobrir a totalidade dessa produção, o foco está voltado a diferentes abordagens e recortes temporais, de modo a dar maior visibilidade à relação entre literatura, leitura e educação. De um modo ou de outro, buscam-se compreender as rupturas e as permanências relativas a um objeto cultural - o livro de ficção - que, tendo sido frequen- 
temente apropriado pela escola, guarda proximidade com a arte e a vida social.

Nesse contexto, a fim de problematizar um primeiro conjunto de questôes que dizem respeito à condição literária do livro infantil, convém estabelecer algumas aproximaçóes com a literatura de caráter geral.

Em Formação da literatura brasileira: momentos decisivos (I98I), publicado pela primeira vez em I959, o professor e crítico literário Antonio Candido discorre acerca da historiografia literária brasileira, com ênfase para os períodos do arcadismo e do romantismo. Segundo a visão de Candido, importa chamar a atenção para esses momentos decisivos, uma vez que, nos séculos XVI, com os autos e cantos de José de Anchieta, e com as primeiras academias do século XVIII, conheceríamos apenas manifestaçóes literárias, e não um sistema literário propriamente dito, o que seria facultado posteriormente, com os homens de letras, a partir da metade do século XVIII e, de um modo mais nítido, na primeira metade do século XIX. Ainda de acordo com a visão de Candido, "trata-se [...] de averiguar quando e como se definiu uma continuidade ininterrupta de obras e autores, cientes quase sempre de integrarem um processo de formação literária” (idem, p. 25). Assim, para o delineamento de uma tese tão original aos estudos literários, ele opera com a tríade autor-obra-público. Desse modo, sublinha a possibilidade de se configurar um sistema literário em solo brasileiro, o qual se estruturou notadamente no período romântico, favorecido pelas circunstâncias do meio social, da história, da produção e da formação. Em fragmento expressivo extraído desse estudo, lê-se:

Para compreender em que sentido é tomada a palavra formação, e por que se qualificam de decisivos os momentos estudados, convém principiar distinguindo manifestaçóes literárias de literatura propria- 
mente dita, considerada aqui um sistema de obras ligadas por denominadores comuns que permitem reconhecer as notas dominantes duma fase. Esses denominadores são, além das características internas (língua, temas, imagens), certos elementos de natureza social e psíquica, embora literariamente organizados, que se manifestam historicamente e fazem da literatura aspecto orgânico da civilizaçáo. Entre eles se distinguem: a existência de um conjunto de produtores literários mais ou menos conscientes do seu papel; um conjunto de receptores, formando os diferentes tipos de público, sem os quais a obra não vive; um mecanismo transmissor (de modo geral, uma linguagem, traduzida em estilos) que liga uns a outros. O conjunto dos três elementos dá lugar a um tipo de comunicação inter-humana, a literatura, que aparece, sob esse ângulo, como sistema simbólico, por meio do qual as veleidades mais profundas do indivíduo se transformam em elementos de contacto entre os homens, e de interpretação das diferentes esferas da realidade (Candido, I98I, pp. 23-4).

Desse fragmento, importa, sobretudo, reter a noção de sistema literário passível de identificação a partir da sistematização de três elementos principais elencados pelo autor: a) um conjunto de produtores literários mais ou menos conscientes de seu papel; b) um conjunto de receptores, formando os diferentes públicos, sem os quais a obra não vive; c) um mecanismo transmissor (de modo geral, uma linguagem, traduzida em estilos) que liga uns a outros.

Assim, para se conhecer a literatura infantil brasileira à luz dessa tese, poderíamos, igualmente, indagar: a) Houve ou tem havido um conjunto de produtores mais ou menos conscientes de seu papel? b) É possível identificar um conjunto bem delimitado de receptores nas diferentes épocas relacionadas à conformação da literatura infantil no Brasil? c) Quais são, afinal, os mecanismos transmissores? 
Embora não configuradas da mesma maneira, essas questôes têm sido recorrentes nas pesquisas que abordam o tema. À guisa de ilustraçáo, salienta-se o estudo "Como aperfeiçoar a literatura infantil”, de Manuel Bergström Lourenço Filho (1943). Nele, o autor acentua o material literário já identificado no Brasil, assim como alguns aspectos de sua evolução. Assim, anota uma primeira fase relacionada a alguns títulos publicados em Portugal e demarca o campo da literatura infantil genuinamente nacional a partir de 1894, com o investimento da Livraria Quaresma Editora, ao publicar Contos da carochinha, de Figueiredo Pimentel. Essa primeira fase, se aferida pela circulação dos livros, conforme o autor, já era positivamente avaliada, visto que, no prefácio da I $8^{a}$ edição, datada de I93I, esclarece-se que a primeira impressão, de I4 abril de I894, esgotou-se em menos de um mês, acrescentando o fato de que cerca de cem mil volumes haviam sido impressos naquele período de 47 anos.

$\mathrm{Na}$ perspectiva de seu balanço, os livros eram poucos - ainda que levemos em conta a produção didática, ou seja, aquela destinada expressamente às escolas primárias da época - e pecavam em qualidade. Menciona o investimento nas traduçóes em ampla escala, além de uma coleção destinada ao público infantil, mais planejada, como foi o caso da Biblioteca infantil, organizada por Arnaldo de Oliveira Barreto e composta por mais de cinquenta volumes, pela Weiszflog \& Irmãos, de São Paulo (que, mais tarde, viria a se chamar Melhoramentos). Deve-se notar, ao lado desse mapeamento, a produçáo de álbuns de gravura, com pouco texto, destinado ao público infantil com menos idade.

Uma segunda fase pôde ser identificada pelo autor a partir de I92I, com a publicação do livro Narizinho arrebitado, de Monteiro Lobato, que deu continuidade a esse projeto, além de se investir na tradução e na adaptação de autores nacionais e estrangeiros, inclusive nos clássicos. O balanço feito por Lourenço Filho 
também levava em conta uma terceira fase, compreendida entre os anos I920 e I940, quando, a seu ver, já haveria uma produção marcada por livros originais em maior volume e autores mais qualificados. Em outras palavras, já seria possível mencionar "[...] uma literatura infantil perfeitamente caracterizada em nosso país" (Lourenço Filho, I943, p. I53). Nesse sentido, em face desse estudo e de tantos outros com que os artigos reunidos neste livro buscam dialogar, é possível considerar a tese proposta por Antonio Candido, quanto à noção de um sistema literário, aplicada à literatura infantil e à literatura juvenil brasileiras.

Outro conjunto de questóes diz respeito à ampla produção de livros na sociedade brasileira contemporânea e, por conseguinte, à problemática da lógica de mercado. Nesse contexto, Fernando de Azevedo, em A formação e a conquista do público infantil (1952), traz algumas contribuiçôes originais e adverte para a necessidade de se analisarem os livros de literatura infantil com ênfase na produção. Nessa linha, enfatiza os inquéritos realizados pelos estudiosos que privilegiavam o gosto infantil. No entanto, a ampla produção identificada por ele nos anos I950 aponta alguns paradoxos: a diversificação da produção para um público que se avoluma e que é "flutuante", e a competição para a conquista de um público-leitor, regida amplamente pelas leis de mercado. Segundo avalia Azevedo:

Todo mundo se acha com direito de escrever para crianças e de tentar o novo gênero. Pois, se não tem público quando se dirigem a adultos, por que não se aventurarem ao público infantil? Essa tendência que pode ser e é, de fato, inicialmente refreada pelas grandes empresas editoras, já seriamente preocupadas em "selecionar", pressupóe a noção de todo ponto falsa de que crianças aceitam tudo, em matéria de literatura. Produção, portanto, intensa, numerosa, desigual (Azevedo, I952, pp. 55-6). 
Diante de tantos e tamanhos problemas e impasses constitutivos da literatura infantil e juvenil brasileiras, a perspectiva dos estudos aqui reunidos póe em cena as relaçóes entre literatura, leitura e educação. Com maior ou menor ênfase, os textos que compóem esta obra podem ser reunidos em três conjuntos: a) um conjunto que se ocupa de delimitar, definir, determinar e avaliar o campo; b) um conjunto que busca discutir o objeto de leitura para crianças e jovens, e que circula em livros, revistas, acervos ou coleçôes; c) e um terceiro que problematiza a leitura literária em suas relações com a educação e o ensino.

No primeiro conjunto, em "Produção acadêmica brasileira sobre literatura infantil (1970-20I6): desafios de um campo em constituição", Maria do Rosário Longo Mortatti e Fernando Rodrigues de Oliveira analisam dissertaçôes e teses que abordam a literatura infantil, defendidas entre 1970 e 20I6, com o objetivo de compreender a produçáo acadêmica sobre o tema nesse período, focalizando três aspectos: crescimento quantitativo, distribuiçáo por áreas de conhecimento e distribuição por regiôes geográficas/ estados brasileiros. Com isso, apontam avanços e contradiçóes na produção examinada em consonância com o conjunto de questôes postas pelo movimento de constituição do campo da literatura infantil em relação à criação e à expansão da pós-graduação no Brasil.

Nesse conjunto ainda, Márcia Cabral da Silva tece consideraçôes a respeito de inflexôes no campo historiográfico, no artigo "Literatura infantil brasileira: conceitos e problemas à luz dos estudos de Leonardo Arroyo e Cecília Meireles". Segundo Silva, trata-se de dois estudiosos com trabalhos originais para a configuração desse campo de investigação. Por um lado, o estudo de base sociológica desenvolvido por Leonardo Arroyo nos anos 1950 recorre a uma metodologia ancorada em diversas fontes documentais, como, por exemplo, catálogos antigos, narrativas memorialísticas e 
livros infantis de outras épocas, o que possibilita encontrar vestígios da produção e de práticas de leitura dos livros de ficção voltados à infância de outras épocas. Além disso, observa as conferências proferidas por Cecília Meireles para os professores nos anos 1940, com destaque principalmente para dois aspectos: a) o lugar de autoridade reservado ao leitor infantil; b) a contribuição das ideias das crianças para a produção de material literário.

No conjunto que se ocupa dos objetos de leitura, um material pouco conhecido entre os leitores de hoje - designado como paleógrafo ou livro de leitura manuscrita -, mas de grande importância para a formação de leitores, é recuperado por Estela Natalina Mantovani Bertoletti: "Literatura manuscrita nas leituras para a infância brasileira (I9OI-I955)". A partir da análise dos textos e autores que compóem o livro Leitura manuscripta - liçóes colligidas, a autora busca compreender o que se destinava à leitura na escola brasileira, na primeira metade do século XX, e, desse modo, o que se projetava na formação de leitores no contexto escolar.

No artigo "O Tico-Tico: espaço de entretenimento e representação da prática escolar republicana”, Cíntia Borges de Almeida e Aline Santos Costa lançam luz às representações de infância e literatura em poemas e contos veiculados na revista O Tico-Tico. Segundo elas, a imprensa das primeiras décadas republicanas representava um veículo importante para a conformação de práticas sociais de leitura que visavam civilizar e moldar as crianças, atuando, ao lado de outras formas escolares, no processo educacional da sociedade da época.

Vivianny Bessão de Asis contribui com o artigo "Estória do galo e do Candimba, de Leonardo Arroyo (196I): contradiçóes e renovação na literatura infantil brasileira”. De acordo com Bessão, é possível compreender, no livro analisado, vários aspectos da transiçâoo de um modelo de literatura infantil associado à tradiçáo de uma época e o início de uma nova tendência na produção literária para 
a infância, desencadeada por mudanças culturais na década de I960, as quais se perpetuam ainda hoje.

$\mathrm{Na}$ sequência, três estudos enfatizam obras selecionadas no âmbito das políticas públicas relacionadas aos livros de literatura destinados às escolas públicas brasileiras. No primeiro deles, "Literatura em minha casa: a seleção de livros para crianças", de Célia Regina Delácio Fernandes e Flávia Ferreira de Paula, analisam-se os acervos do Programa Nacional Biblioteca da Escola (PNBE), nas ediçóes de 200I, 2002 e 2003 - anos que correspondem ao projeto "Literatura em Minha Casa". Nesse estudo, as autoras buscam compreender como a qualidade dos livros subsidia os critérios de seleção para as compras governamentais, com especial relevo para as obras que se repetem, a localização geográfica das editoras envolvidas, os autores e ilustradores recorrentes, as temáticas mais frequentes, o espaço físico no qual as histórias se passam, a pluralidade étnica, os elementos culturais e as imagens do regionalismo brasileiro presentes nos livros escolhidos para os acervos.

A seguir, Mirian Hisae Yaegashi Zappone, em "Literatura juvenil brasileira: espaço e representação social em acervo do PNBE”, traz, em acréscimo, dados atuais e originais. Zappone seleciona as narrativas representativas que compuseram o Programa Nacional Biblioteca na Escola (PNBE) de 2013 para os anos finais do ensino fundamental, com vistas à análise em tela. Segundo a autora, o exame ancorou-se na metodologia qualiquantitativa, desenvolvida por Dalcastagnè (2007), e baseou-se em um levantamento da representação dos grupos sociais identificados.

No terceiro artigo desse conjunto, "Infância e literatura: entre conceitos, palavras e imagens", de Patrícia Corsino, destaca-se o diálogo entre infância e literatura, na perspectiva de se compreenderem a literatura infantil como arte e o livro infantil contemporâneo como espaço de articulaçáo entre a arte da palavra e a literatura, e as artes visuais e a arte de design gráfico 
editorial, analisando essas relaçóes em um livro que também compóe o acervo do PNBE de 2006, intitulado Raposa, de Margaret Wild e Ron Brooks. Nessa linha, apresenta os conceitos de infância e literatura segundo uma abordagem histórica, com vistas a dialogar com as seis propostas de Ítalo Calvino e com o direito à literatura, defendido por Antonio Candido.

No último conjunto, o artigo "Leituras literárias em grupo: experiências, desafios e objetivos", de Neide Luzia de Rezende e Gabriela Rodella de Oliveira, traz importantes contribuiçóes para os estudos contemporâneos sobre a leitura de literatura, ao se voltar para a didática da literatura, para a leitura literária e para a formação do leitor na escola. No texto, as autoras colhem três situações de leitura em grupo para discutir as possibilidades de se traçar um percurso que leve à emergência e à manifestaçáo do sujeito-leitor.

Aos estudos relacionados à leitura literária, especialmente de poemas, soma-se a pesquisa realizada por Ninfa Parreiras, que, além de nos apresentar os primeiros poemas e poetas que se ocuparam de escrever para crianças a partir do conceito de poesia, focaliza o livro organizado por Leo Cunha, Poesia para crianças, conceitos, tendências e práticas, obra que reúne seis artigos de cinco autores sobre poesia para a infância. O livro está organizado em capítulos autônomos que, segundo Parreiras, podem ser lidos separadamente, embora abordem conteúdos relacionados à poesia na vida da criança.

Assim, convidamos os leitores interessados na estreita e complexa relação entre literatura, leitura e educação a enveredar por esta obra tecida a várias mãos, compartilhando conosco reflexões, indagaçóes e (bons) problemas que venham a compor e contribuir para o alargamento e a verticalizaçáo do campo pelo qual circulam e dialogam esses vetores, bem como para a qualificação da produção de livros que a eles correspondam. 
Este livro contou com o financiamento da Fundação Carlos Chagas Filho de Amparo à Pesquisa no Estado do Rio de Janeiro (Faperj), por meio de recursos oriundos da bolsa "Jovem Cientista do Nosso Estado".

Boa leitura! 


\title{
1 \\ Produção acadêmica brasileira sobre literatura infantil (1970-2016): desafios de um campo em constituição ${ }^{1}$
}

\author{
Maria do Rosário Longo Mortatti \\ Fernando Rodrigues de Oliveira
}

\section{Introdução}

Este artigo dialoga diretamente com outras publicaçóes resultantes de pesquisas pioneiras vinculadas ao Grupo de Pesquisa História do Ensino de Língua e Literatura no Brasil (GPHELLB). ${ }^{2}$ No momento em que o grupo foi criado (I994),

I Este texto foi publicado na revista Teias, v. I6, n. 4I (20I5), e adaptado para este livro.

2 O objetivo geral do grupo é contribuir para a produção de uma história do ensino de língua e literatura no Brasil que auxilie na busca de soluçóes para os problemas desse ensino, no presente, e também para a formação de pesquisadores capazes de desenvolver pesquisas históricas que propiciem avanços em relação aos campos de conhecimento envolvidos. O método de investigação está centrado na abordagem histórica, com a análise da configuração textual de fontes documentais, conforme conceito proposto por Magnani (1993)/Mortatti (2000). O estudo se subdivide em seis núcleos temáticos/linhas de pesquisa: história da alfabetização; história do ensino de língua portuguesa; história do ensino de literatura; história do ensino de literatura infantil e juvenil; história da formação de professores; memória e história da educação. Deve-se ressaltar, porém, que nem sempre é possível delimitar a vinculaçẫo dos trabalhos a uma única linha, já que, conforme a temática interdisciplinar do grupo, abordam-se temas inter-relacionados, ainda que cada um deles tenha seu foco e objetivo específicos. O GPHELLB está cadastrado no Diretório dos Grupos de Pesquisa do Brasil - CNPq, e sua sede se encontra no campus de Marília da Unesp. Desde a sua criação, é coordenado/liderado por Mortatti. Atualmente, tem como vice-líder a Profa. Dra. Rosa Fátima de Souza. Informaçôes disponíveis em: <http://www.marilia.unesp.br/gphellb>. 
[...] as pesquisas históricas em educação já conquistavam o devido prestígio acadêmico-científico, [e] o GPHELLB assumiu, como principal desafio, a necessidade de definição de objetos de estudo, de fontes documentais, de vertentes teóricas e de abordagens metodológicas, em consonância com: as necessidades históricas apontadas por estudos de pesquisadores brasileiros e estrangeiros; a característica interdisciplinar da temática do grupo; e a busca de diálogo com áreas/campos de conhecimentos correlatos [à temática do grupo], especialmente Educação, Letras, Linguística, História (Mortatti, 20II, p. 69).

Assim, em consonância com esse desafio, durante os 23 anos de funcionamento do grupo (até o momento em que este texto foi construído), as atividades vêm produzindo resultados articulados entre si, com importante contribuição para a compreensão da temática e para a configuração e/ou consolidação de campos de conhecimento correlatos. Entre essas atividades, destacam-se, pela abrangência de seus objetivos e pela função de síntese articuladora e propositiva, dois projetos desenvolvidos por todos os integrantes e coordenados por Mortatti:

- "História do ensino de língua e literatura: repertório documental republicano" (1999-2003; CNPq e Fapesp) (Mortatti, 2003), cujo objetivo foi organizar, sistematizar e divulgar um instrumento de pesquisa com caráter de repertório de fontes documentais relativas a cada uma das linhas de pesquisa do grupo;

3 Nesse documento, estão relacionadas 2.025 referências de diferentes tipos de textos (livros, capítulos, artigos, números de periódicos, teses e dissertaçóes, publicações institucionais, livros didáticos, obras de referência, prefácios/apresentaçôes) produzidos por brasileiros entre 1874 e 2002. As referências a teses e dissertações estão assim distribuídas entre as linhas de pesquisa do GPHELLB: alfabetização, I38; literatura infantil e juvenil, I03; ensino de língua portuguesa, 95; formaçăo de professores de língua e literatura, 86; ensino de literatura, 44. O total de referências a textos 
- "Bibliografia brasileira sobre história do ensino de língua e literatura no Brasil” (2009-20II; CNPq - Edital Universal) (Mortatti, 20I2), que, em continuidade ao anterior, teve o objetivo de atualizar, sistematizar e produzir uma obra de referência, contendo especificamente bibliografia sobre história do ensino de língua e literatura no Brasil, referente a cada uma das linhas de pesquisa do GPHELLB. ${ }^{4}$

Ao mesmo tempo que a formulação desses projetos veio sintetizar o conjunto de pesquisas concomitantes ou anteriores do GPHELLB, seus resultados têm subsidiado muitas outras pesquisas e publicaçóes acerca de temas vinculados às linhas do grupo. Entre os mais recentes, destacamos o artigo "50 anos de produção acadêmica brasileira sobre alfabetização: avanços, contradiçōes e desafios" (Mortatti et al., 20I4).

Como ocorreu em relação à alfabetização, também a produção acadêmica brasileira sobre literatura infantil's teve início no contexto político da ditadura (civil-)militar imposta no Brasil com o golpe de 1964, quando,

sobre literatura infantil e juvenil é 542 (incluindo teses e dissertaçôes), com datas de publicação entre 1885 e 2002.

4 Nesse segundo documento, estão reunidas 2.044 referências a diferentes tipos de textos (delimitados a livros, capítulos, artigos e teses e dissertaçôes), produzidos por brasileiros entre 2003 e 2012. As referências a teses e dissertações estão assim distribuídas entre as linhas de pesquisa (reconfiguradas e renomeadas a partir de 20I4) do GPHELLB: história da alfabetização, ıı; história da literatura infantil e juvenil, 204; ensino de língua portuguesa, 203; história da formação de professores, 59; história do ensino de literatura, 82. O total de referências a textos sobre literatura infantil e juvenil é 477 (incluindo teses e dissertações), com datas de publicação entre 2003 e 2012.

5 Considerando a complexidade do tema e o fato de que também este artigo se insere na história da produçáo de discursos sobre literatura infantil, optamos por utilizar "[...] a expressão 'literatura infantil' para designar os textos literários destinados a um público não adulto e o correspondente campo de conhecimento, independentemente da superespecializaçáo classificatória, hoje em voga, que faz distinçóes entre 'literatura infantil', 'literatura infantojuvenil' e 'literatura juvenil'” (Mortatti, 200I, p. I79). 
[...] em consonância com os planos de desenvolvimento estratégico do país, também foram implementadas políticas governamentais para educação, ciência e tecnologia, como a criação da pós-graduação, em 1965, e as reformas universitária, em 1968, e do ensino fundamental, em i97I.

A despeito desse contexto de origem, muitas dessas iniciativas se consolidaram, sem sofrer mudanças substanciais, mesmo depois da abertura política e da redemocratização do país (Mortatti et al., 20I4, p. 7).

É também nesse contexto que se verificam o chamado boom da produção brasileira de livros de literatura infantil e muitas iniciativas referentes à discussão de problemas e propostas que dizem respeito à leitura e à literatura infantil.

Desde então, constata-se franca expansão da produção acadêmica sobre literatura infantil, o que torna possível e necessária sua avaliação. Mas, embora essa situação se assemelhe, por exemplo, à que apontamos no artigo referente à produção acadêmica sobre alfabetização, deve-se destacar uma diferença crucial. No que tange à produçáo brasileira sobre literatura infantil, ainda não foram desenvolvidas pesquisas do tipo "estado da arte"/“estado do conhecimento", ${ }^{6}$ cuja importância consiste em trazer a lume o "conhecimento em construção", propiciando

[... a indicação das possibilidades de integração de diferentes perspectivas, aparentemente autônomas, a identificação de duplicações ou contradiçôes e a determinação de lacunas e vieses (Soares, I989, p. 3).

6 No que diz respeito à alfabetização, destaca-se pesquisa pioneira desse tipo realizada por Soares (1989) e complementada por Soares e Maciel (2000). Existem também balanços parciais de aspectos dessa produção, como os de Espósito (1992), Mortatti (2003; 2012; 20I4a), Mortatti et al. (20I4) e Maciel (20I4). 
Podem, assim, resultar, principalmente, na abertura de espaço para problematização a respeito do que se sabe, visando à proposição de novos temas, objetos e vertentes teórico-metodológicas para o desenvolvimento de novas pesquisas que fazem falta (Mortatti et al., 20I4, p. 8).

Há, porém, balanços parciais dessa produção sobre literatura infantil, como os de Mello Neto (1988), Magnani (1998), Mortatti (200I; 2008; 20I4b) e Oliveira (20I2), cuja importância deve ser destacada, na medida em que disponibilizam informaçóes e podem ser retomados como ponto de partida para pesquisas mais aprofundadas.

Com base nos dados reunidos nos dois projetos integrados e nos balanços parciais mencionados, enfocamos, neste artigo, a produção acadêmica sobre literatura infantil vinculada a programas de pós-graduação stricto sensu: teses e dissertaçóes ${ }^{7}$ defendidas entre 1970 e 20I6, resultantes de pesquisas desenvolvidas com ou sem o financiamento de agências públicas, avaliadas e aprovadas por banca examinadora, tendo como objetivo a obtençáo dos respectivos títulos acadêmicos, e integrando o processo de formação de pesquisadores e de professores universitários.

Como marco inicial da pesquisa, estabelecemos o ano de 1970, no qual foi defendido o primeiro trabalho acadêmico sobre literatura infantil, em curso/programa de pós-graduação do país. Quanto ao marco final, estabelecemos o ano de 2016, com base nos dados que se encontram disponíveis no banco de teses da Capes. Os dados relativos à linha "Literatura infantil" reunidos nos dois documentos (2003 e 2012) mencionados foram reconferidos e, quando necessário, complementados mediante nova consulta

7 Teses de concurso de livre-docência ou de cátedra não foram aqui consideradas. 
ao Banco de Teses da Coordenadoria de Aperfeiçoamento de Pessoal de Nivel Superior (Capes). ${ }^{8}$

E, considerando os limites e os objetivos deste artigo, optamos por analisar e problematizar principalmente três aspectos dessa produção: crescimento quantitativo, distribuição por áreas de conhecimento e distribuição por regióes geográficas/estados brasileiros. O objetivo é contribuir para a compreensão da produção acadêmica brasileira sobre literatura infantil, relacionando-a com o movimento histórico de constituição de um campo de conhecimento, ao longo do século XX, e com o movimento de criação e expansão da pós-graduação no Brasil.

\section{I.I Literatura infantil: um gênero literário e um campo de conhecimento}

Estudos brasileiros clássicos sobre literatura infantil registram a "origem" ou a "formação" desse gênero literário no Brasil a partir do final do século XIX, com a publicação de livros escolares voltados ao ensino da leitura, a maior parte composta por traduçóes e/ ou adaptaçóes de livros europeus (Arroyo, 1968; Lajolo e Zilberman, 1984).

Com a proclamação da República, a preocupação com a formação de professores, a expansão do ensino primário, as contribuiçóes da pedagogia e da psicologia para a definição da infância, entre muitas outras inovaçóes, trouxeram a necessidade de novos

8 Devido à dispersão geográfica dos programas de pós-graduação com trabalhos acadêmicos sobre o tema em questáo, consultar as bases de dados on-line de bibliotecas universitárias, uma a uma, tornou-se algo pouco produtivo e inviável, uma vez que não é possível saber previamente quais instituiçóes contam com trabalhos desse tipo e sobre esse tema. Apesar disso, consultamos as principais bases de dados on-line de bibliotecas universitárias do país, mas privilegiamos a consulta direta ao Banco de Teses da Capes. 
métodos e materiais de ensino, particularmente aqueles relacionados ao ensino de leitura e escrita.

De acordo com Arroyo (1968), a "literatura escolar" desempenhou importante papel nesse processo de constituição de modelos de educaçáo escolar, de ensino de leitura e escrita e da literatura infantil brasileira. Representa, assim, um "corpus precursor", como um dos "estágios do processo evolutivo" da literatura infantil brasileira propriamente dita, que, segundo esse pesquisador, tem início com a publicação de Narizinho arrebitado (I92I), de Monteiro Lobato. Essa "literatura escolar" ainda contribuiu para disseminar e consolidar um conceito de literatura infantil brasileira como um gênero didático (nele subsumida sua condição de gênero literário) e como um ramo da Pedagogia (nele subsumido seu pertencimento ao ramo das Letras).

Desse ponto de vista, a constituição da literatura infantil brasileira está diretamente relacionada com e mesmo condicionada pela educaçáo escolar como um espaço de formaçáo de leitores e de circulação de textos, com base nas necessidades impostas por um projeto republicano de nação, baseado na modernização e enfocando a urbanização e a escolarização das "massas" (Mortatti, 20I5, s.p.).9

Também o correspondente tema de pesquisa/campo de conhecimento tem sua "origem" mais remota nas tímidas tematizaçóes sobre literatura infantil produzidas no final do século XIX e início do século XX. E, embora na primeira metade do século XX se registrem um considerável crescimento da produçáo de livros de literatura infantil e a profissionalização do mercado editorial voltado a esse segmento (Lajolo e Zilberman, 1984), tardou para a produção escrita sobre o tema acompanhar esse

9 Nessa citação, tem-se uma tradução livre do original em inglês. 
ritmo. Nesse período, educadores e intelectuais passaram gradualmente a tematizar - por meio de problematizaçóes, tentativas de conceitualização e delimitação, contidas em livros de caráter ensaísta, manuais de ensino e artigos - a literatura infantil como um gênero subsumido na produção de livros para crianças (Magnani, I998, p. 248). ${ }^{\text {io }}$

A produção escrita sobre o tema ganhou impulso na segunda metade do século XX. Nesse período, Lenyra Fraccaroli ${ }^{\text {II }}$ organizou a primeira bibliografia brasileira sobre literatura infantil, e foram publicadas obras que se tornaram clássicas, como as de Meireles (I95I), Arroyo (I968), ${ }^{\text {I2 }}$ Coelho (I98I), Lajolo e Zilberman (I984) e Perrotti (I986). Constituiu-se também outro tipo de produção sobre o tema, em decorrência da criação, na década de I950, da disciplina "Literatura infantil" no currículo dos cursos de formação de professores primários no estado de São Paulo. Acompanhando esse processo, ocorreu o que podemos considerar o primeiro "surto" de produção nacional sobre literatura infantil (Mello Neto, 1988). Muitas das publicaçôes desse período e as que se seguiram até a década de I970, em livros, capítulos ou artigos, foram motivadas pelo - ou estavam relacionadas ao - ensino da literatura infantil nos cursos de formação de professores (Oliveira, 2015).

\footnotetext{
Io Entre as primeiras tematizaçóes, destacam-se os artigos de Azevedo (I952) e Lourenço Filho (1943). Sobre o último, ver especialmente Bertoletti (20I2), resultante de pesquisa vinculada ao GPHELLB e orientada por Mortatti.

II Essa professora e bibliotecária contribuiu para as tematizaçóes sobre literatura infantil, especialmente por meio da elaboração do pioneiro e emblemático catálogo (Fraccaroli, I953) com bibliografia de literatura infantil em língua portuguesa. A esse respeito, ver Pasquim (2016), também resultante de pesquisa em andamento vinculada ao GPHELLB, sob a orientação de Mortatti.

I2 Arroyo é autor igualmente pioneiro e emblemático de livro sobre história da literatura infantil. A esse respeito, ver especialmente Assis (20I6), também resultante de pesquisa vinculada ao GPHELLB, sob a orientação de Mortatti.
} 
A partir da década de 1970, somando-se a esses "lugares" de produção sobre literatura infantil, foram conquistando espaço outras iniciativas, responsáveis pela

[...] emergência, na cena acadêmica, de um campo de conhecimento específico, processo para o qual [concorreram], dentre outros: a gradativa inserção e institucionalização da literatura infantil como matéria de ensino e/ou disciplina em currículos de licenciaturas em Pedagogia e Letras - a exemplo do que já vinha ocorrendo no Curso Normal; a organização de entidades e projetos - governamentais ou não - grupos acadêmicos e de pesquisa, seminários e congressos relativos à discussão de problemas e propostas concernentes à leitura e à literatura infantil; e, sobretudo, a expansão dos cursos de pós-graduação, acompanhada de uma crescente produção acadêmica divulgada sob o formato de teses/dissertaçóes, artigos especializados e livros (Mortatti, 200I, p. 179).

Inicialmente em pequena quantidade, por serem, à época, também poucos os cursos/programas de pós-graduaçáo no Brasil, desde entáo a produção acadêmica sobre o tema expandiu-se consideravelmente, tornando-se objeto de interesse em diferentes áreas do conhecimento.

Somando-se às primeiras tematizaçóes esparsas, a produção acadêmica em análise integra a história da produçáo do discurso sobre literatura infantil, assim como a história do correspondente campo de conhecimento, em cuja constituiçáo se destacam textos e autores que se foram constituindo como referência obrigatória para os que tomam a literatura infantil como tema de estudo e pesquisa.

Embora recentes, em comparação a outros campos correlatos, entre os inúmeros aspectos observáveis ao longo do movimento de constituiçẫo desse campo, as teses e dissertaçôes acadêmi- 
cas podem auxiliar na compreensão dos avanços, das contradições e dos desafios decorrentes da "condição de origem" da literatura infantil (como gênero literário e tema de pesquisa), que caracteriza sua

[...] unidade múltipla determinantemente constitutiva [...], o que implica, por um lado, considerar os textos assim denominados como pertencentes a um gênero textual simultaneamente literário $e$ didático, e, por outro lado, reconhecer que os termos literatura $\mathrm{e}$ infantil elou juvenil não se encontram em relaçáo de oposição, mas de complementaridade, embora indiquem hierarquização semântica constitutiva de sua natureza: substantivamente literatura, cujo atributo qualificativo é infantil e/ou juvenil (Mortatti, 2008, p. 49, grifos no original).

Com base na constatação dessa complexidade, a designação "literatura infantil" sintetiza,

[...] de modo relativamente arbitrário (mas não inconsequente) um ponto de partida [...] um fenômeno literário-cultural-social-campo de ação, prática, observável em discursos delprodução de LIJ - e a um correspondente tema de pesquisalcampo de conhecimento - sistematização teórica (e, por vezes, crítico-normativa) do fenômeno, observável em discursos sobre/produção sobre LIJ (Mortatti, 2008, p. 45, grifos no original).

\section{I.2 A constituição dos estudos em nível de pós-graduação sobre literatura infantil}

No Brasil, a implantação oficial do sistema de pós-graduação teve início em 1965 , com o Parecer $n^{\circ}$. 977, emitido pelo Conselho Federal de Educação (Parecer Sucupira). No entanto, antes 
dessa data, já estavam em funcionamento no país alguns cursos de mestrado e doutorado, resultantes de parcerias entre instituiçóes brasileiras e norte-americanas (Santos, 2003).

Com a criação e a expansão da pós-graduação, especialmente ligada às áreas das Ciências Humanas, o cenário da produção de conhecimento no país passou a apresentar algumas mudanças. Segundo Gatti (1983), essas mudanças se relacionam com a "[...] composição temática da produção científica e tecnológica [...], como a relativa às metodologias utilizadas para encaminhar estes temas" (p. 4). Nesse contexto, as questôes sobre literatura infantil também se tornaram tema de pesquisas desenvolvidas em nível de pós-graduação stricto sensu, configurando importante mudança nos estudos e abordagens desse gênero literário.

Até a década de 1970 , a produção sobre literatura infantil apresentava características mais de conceituação, definição e problematização em relação ao seu ensino e à formação do leitor, com acentuada associaçáo ao contexto escolar. Com o crescente aumento da produção acadêmica sobre literatura infantil em nível de pós-graduação, àquelas características, acrescentaram-se novas abordagens, novas metodologias e novos objetivos, especialmente os advindos da área de Letras, que começaram a subsidiar as pesquisas sobre esse gênero literário.

Como é possível observar no quadro a seguir, entre 1970 e 2016 foram defendidos, no Brasil, I.246 trabalhos acadêmicos -223 teses e I.023 dissertaçóes - com crescimento exponencial de quantidade por década.

Quadro I.I. Teses e dissertações sobre literatura infantil, por década de publicação

\begin{tabular}{lccc}
\hline \multicolumn{1}{c}{ Tipo de texto } & Teses & Dissertaçóes & Total por década \\
Década & & & 6 \\
\hline I970-1979 & 2 & 04 & 33 \\
\hline I980-1989 & 7 & 26 & \\
\hline
\end{tabular}




\begin{tabular}{lccc}
\hline I990-1999 & 26 & $\mathrm{I} 32$ & $\mathrm{I} 58$ \\
\hline 2000-2009 & 97 & 404 & 501 \\
\hline 2010-[2016] & 91 & 457 & 548 \\
\hline Total por tipo de texto & 223 & 1.023 & - \\
\hline Total geral: 1.246 & & & \\
\hline
\end{tabular}

Fonte: Mortatti (2003; 20I2) e Banco de teses e dissertaçôes da Capes.

O primeiro trabalho acadêmico sobre literatura infantil produzido no Brasil foi desenvolvido no Instituto de Psicologia da Universidade de São Paulo (USP). Trata-se de uma dissertação em Psicologia Escolar, defendida em 1970 por Zilda Augusta Anselmo, intitulada Alguns fatores condicionantes da literatura infantil didática. Em 1972, foi defendida a primeira tese sobre literatura infantil: A lingua portuguesa nas obras infantis de Monteiro Lobato, de Nilce Sant'Anna Martins, no curso de pós-graduação em Letras da Faculdade de Filosofia, Letras e Ciências Humanas (FFL$\mathrm{CH})$ da USP. Ainda na década de I970, foram defendidas outras três dissertaçóes e uma tese em cursos de pós-graduação de uma das seguintes áreas: Educação, Letras e Linguística - Criança, jovens e literatura, de Nise Pires (1976), na área de Educação, pela Fundação Getulio Vargas (RJ); O universo narrativo de Monteiro Lobato, um mundo de mentira e de verdade, de Ana Mariza Ribeiro Filipouski (1977), na área de Letras, pela Universidade Federal do Rio Grande do Sul; e História infantil em sala de aula: semiótica de personagens, de José Fernando Miranda (1978), na área de Linguística, pela Pontifícia Universidade Católica do Rio Grande do Sul. A tese também foi desenvolvida na área de Letras, vinculada à FFLCH-USP: Usos e abusos da literatura na escola: Bilac e a literatura escolar na República Velha, de Marisa Philbert Lajolo (1979).

Com a expansão da pós-graduação no Brasil, também aumentou a quantidade de trabalhos acadêmicos sobre o tema em questão. Entre 1980 e I989, foram defendidas 26 dissertaçóes e sete teses. Na década de I990, foram defendidos 158 trabalhos: 
I32 dissertaçóes e 26 teses. Entre 2000 e 2009 , foram defendidas 404 dissertaçóes e 97 teses. Na década de 2000, o total desses trabalhos - 50I - corresponde a 40,21\% do total de teses e dissertaçôes sobre literatura infantil localizadas até o momento. E, em relação ao início da década de 2010 (considerando o ano de 2016 o marco final da pesquisa que resultou neste artigo), foi possível localizar 548 trabalhos - 457 dissertaçóes e 9I teses.

Esses dados são indicativos de que, além de as pesquisas sobre literatura infantil haverem acompanhado o processo de expansão da pós-graduação no Brasil, esse gênero literário também vem-se tornando, cada vez mais, objeto de interesse de um número maior de pesquisadores. É o que se pode constatar pela quantidade de trabalhos defendidos nos últimos seis anos - 20IO2016 -, equivalente a $43,98 \%$ do total da produção de teses e dissertaçóes brasileiras sobre o tema.

\section{I.3 Literatura infantil como tema de pesquisa em diferentes áreas}

Como mencionamos, os primeiros trabalhos acadêmicos sobre literatura infantil produzidos na década de 1970 foram desenvolvidos nas áreas de Letras, Educação, Linguística e Psicologia, que subsidiaram as primeiras pesquisas sobre esse gênero literário. No entanto, a partir dos anos 1990, esse cenário começou a se modificar, sobretudo com a inserção gradual do tema em outras áreas de pesquisa. No Quadro I.2, é possível observar a distribuição, por área de conhecimento, de teses e dissertaçóes sobre o tema. 
Quadro I.2. Teses sobre literatura infantil, por área de conhecimento

\begin{tabular}{llc}
\hline $\begin{array}{l}\text { Grande área } \\
\text { Capes }\end{array}$ & Área de conhecimento & $\begin{array}{c}\text { Total de teses } \\
\text { por área }\end{array}$ \\
\hline Linguística, Letras e Artes & Letras & I05 \\
\cline { 2 - 3 } & Linguística & 49 \\
\cline { 2 - 3 } & Artes & OI \\
\hline Ciências Humanas & Educação & 45 \\
\cline { 2 - 3 } & Psicologia & O9 \\
\cline { 2 - 3 } & História & O4 \\
\cline { 2 - 3 } & Sociologia & OI \\
\hline Ciências Sociais Aplicadas & Comunicação & O5 \\
\cline { 2 - 3 } & Fundamentos do Serviço Social & OI \\
\hline Multidisciplinar & Interdisciplinar & OI \\
\cline { 2 - 3 } & Ensino & OI \\
\hline Ciências da Saúde & Medicina & \\
\hline
\end{tabular}

Total: 223

Fonte: Mortatti (2003; 20I2) e Banco de Teses e Dissertaçóes da Capes.

Em relação às teses produzidas até I990, todas foram defendidas em cursos/programas de pós-graduação da área de Letras e Linguística. Entre as nove teses defendidas entre 1972 e 1989, seis se inserem na área de Letras e três, na área de Linguística.

A primeira tese vinculada à grande área de Ciências Humanas foi defendida em 1992, na área de Psicologia. Trata-se da tese de Lígia Assumpção Amaral, intitulada Espelho convexo: o corpo desviante no imaginário coletivo pela voz da literatura infantojuvenil, defendida no Instituto de Psicologia da USP.

Em I994, foi defendida a primeira tese sobre literatura infantil na área de Educação e, em I997, na área de História. A primeira tese na área de Educação é de autoria de Aurea Maria de Oliveira, intitulada Literatura infantil e desenvolvimento moral: a construção da noção de justiça em crianças pré-escolares, defendida na Faculdade de Educação da Universidade Estadual de Campinas; e a primeira tese na área de História é de Maria do Rosá- 
rio da Cunha Peixoto, intitulada Palavras têm segredos: imagens de criança na literatura infantil brasileira de resistência, defendida na FFLCH-USP.

Durante a década de 2000, a área de Letras continuou a ser a grande responsável pela produçáo de teses sobre literatura infantil, enquanto a área de Educação tornou-se a segunda em quantidade de trabalhos sobre o tema. Nessa década, também foram defendidas teses nas áreas de Comunicação, História, Sociologia e Ensino (Ciências e Matemática).

$\mathrm{Na}$ década em curso, observa-se um grande número de trabalhos nas áreas de Letras e Educação. Existem, porém, trabalhos defendidos também em outras áreas até então sem produção sobre o tema: Interdisciplinar (História da Ciência), Medicina, Artes e Fundamentos do Serviço Social.

Entre os aspectos característicos da distribuição das teses por área de conhecimento dos programas de pós-graduação em que foram defendidas, observa-se que, embora Letras continue a ser a principal área em que se produzem as teses sobre literatura infantil, o tema vem, gradativamente, sendo estudado em outras áreas, especialmente a de Educação, responsável por 20,17\% do total das teses que localizamos.

No caso das dissertaçôes, é grande a variação das áreas de conhecimento com produção de trabalhos sobre literatura infantil, como se observa no quadro a seguir. E, diferentemente das teses, essa variaçáo teve início na década de 1970, quando se produziram as primeiras dissertaçóes sobre o tema.

Quadro 1.3. Dissertaçóes sobre literatura infantil, por área de conhecimento

\begin{tabular}{llc}
\hline $\begin{array}{l}\text { Grande área } \\
\text { Capes }\end{array}$ & Área de conhecimento & \multicolumn{2}{c}{$\begin{array}{c}\text { Total de dissertaçóes } \\
\text { por área }\end{array}$} \\
\hline Linguística, Letras e Artes & Letras & 479 \\
\cline { 2 - 3 } & Linguística & $\mathrm{II} 3$ \\
\cline { 2 - 3 } & Artes & $\mathrm{O} 2$ \\
\hline
\end{tabular}




\begin{tabular}{|c|c|c|}
\hline \multirow[t]{9}{*}{ Ciências Humanas } & Educação & $3 \mathrm{I} 3$ \\
\hline & Psicologia & I8 \\
\hline & História & 07 \\
\hline & Sociologia & $\mathrm{O} 2$ \\
\hline & Geografia & OI \\
\hline & Teologia & $\mathrm{O} 4$ \\
\hline & Ética & OI \\
\hline & Antropologia & 2 \\
\hline & Ensino Profissional & OI \\
\hline \multirow[t]{5}{*}{ Ciências Sociais Aplicadas } & Ciência da Informaçẫo & II \\
\hline & Comunicação & 15 \\
\hline & Desenho industrial & 05 \\
\hline & Serviço Social & OI \\
\hline & Biblioteconomia & OI \\
\hline \multirow[t]{3}{*}{ Multidisciplinar } & Interdisciplinar & I5 \\
\hline & Sociais e Humanidades & 16 \\
\hline & Ensino & 13 \\
\hline Engenharias & Engenharia de Produção & oI \\
\hline Ciências da Saúde & Clínica Médica & OI \\
\hline Ciências Exatas e da Terra & Geociências & OI \\
\hline
\end{tabular}

Total: $\mathbf{1 . 0 2 3}$

Fonte: Mortatti (2003; 20I2) e Banco de Teses e Dissertaçôes da Capes.

Como mencionado, o primeiro trabalho acadêmico sobre literatura infantil foi uma dissertação defendida em I970, no curso de mestrado em Psicologia da USP. Ainda na década de I970, outra dissertação foi defendida em curso de pós-graduação de área diversa da de Letras-Linguística. Trata-se de uma dissertação defendida no curso de mestrado em Educação da Fundação Getulio Vargas, na cidade do Rio de Janeiro. Como já mencionado, essa dissertação é de autoria de Nise Pires, sendo intitulada Crianças, jovens e literatura (1976).

$\mathrm{Na}$ década de I980, foi defendida uma dissertação no curso de mestrado em Ciência da Comunicação, que integra a área de Ciência da Informação, da Escola de Comunicações e Artes da 
USP: Crise do discurso utilitário: contribuição para o estudo da literatura brasileira para crianças e jovens (1984), por Edmir Perrotti.

Nos anos 1990, alguns trabalhos sobre literatura infantil começaram a ser desenvolvidos nas áreas de Ciência da Informação e Comunicação e Semiótica, hoje reunidas, conforme classificação da Capes, na área de Comunicação, vinculada à grande área de Ciências Sociais Aplicadas.

A partir da década de 2000, ampliaram-se a diversificação e a variação das áreas com dissertaçôes sobre literatura infantil. Observam-se trabalhos nas áreas de Desenho Industrial (Design), Engenharia de Produçáo, Sociologia, Serviço Social, Ciências da Religiáo, Artes e Interdisciplinar. Esses aspectos possibilitam que se observe o movimento de interdisciplinarizaçáo da literatura infantil como tema de pesquisa, dada a sua característica "multifacetada" (Mortatti, 2008). Tal movimento vem-se acentuando nos últimos anos, tendo em vista que, apenas nos últimos seis anos (20I0-20I6), foi possível identificar outras nove áreas de conhecimento com produção de dissertaçóes sobre literatura infantil: Geografia, Teologia, Ética, Antropologia, Ensino Profissional, Sociais e Humanidades (multidisciplinar), Ensino (multidisciplinar), Clínica Médica e Geociências.

Nesse sentido, ainda que a área de Letras - como no caso das teses - se destaque, com a maior quantidade de dissertaçóes sobre o tema (479 dissertaçóes, correspondendo a $46,82 \%$ do total daquelas localizadas), um conjunto significativo de dissertaçôes (544) foi defendido em cursos/programas de pós-graduação de 23 diferentes áreas, com destaque para a área de Educação (correspondendo a 30,59\% do total das dissertaçóes localizadas). 
Ainda em relação às dissertaçóes, cabe destacar que localizamos 43 trabalhos sobre literatura infantil em cursos de mestrado profissional, ${ }^{13}$ criados em 2009.

\section{I.4 A produçáo acadêmica brasileira sobre literatura infantil nas regióes geográficas/estados brasileiros}

Assim como gradativamente a produção de teses e dissertações sobre literatura infantil foi distribuída pelas diferentes áreas do conhecimento, também esses trabalhos foram produzidos em programas de pós-graduação de diferentes regióes geográficas do país.

Quadro I.4. Teses sobre literatura infantil, por década de publicação e por regiấo geográfica/estado.

\begin{tabular}{|c|c|c|c|c|c|c|c|c|c|c|c|c|c|c|}
\hline \multirow{2}{*}{$\begin{array}{l}\text { Regiáo/ } \\
\text { Estado } \\
\text { Década de } \\
\text { publicaçáo }\end{array}$} & \multicolumn{4}{|c|}{ Sudeste } & \multicolumn{3}{|c|}{ Sul } & \multicolumn{5}{|c|}{ Nordeste } & \multicolumn{2}{|c|}{$\begin{array}{l}\text { Centro- } \\
\text {-Oeste }\end{array}$} \\
\hline & SP & RJ & MG & ES & RS & SC & PR & BA & PB & PE & CE & RN & GO & TO \\
\hline I970-1979 & $\mathrm{O} 2$ & - & - & - & - & - & - & - & - & - & - & - & - & - \\
\hline 1980-1989 & $\mathrm{O} 3$ & $\mathrm{O} 2$ & - & - & $\mathrm{O} 2$ & - & - & - & - & - & - & - & - & - \\
\hline 1990-1999 & 16 & $\mathrm{O} 4$ & $\mathrm{O} 3$ & - & $\mathrm{O} 2$ & - & - & - & OI & - & - & - & - & - \\
\hline 2000-2009 & 42 & o8 & $\mathrm{O} 2$ & - & $3 \mathrm{I}$ & $\mathrm{O} 2$ & $\mathrm{O} 2$ & - & OI & $\mathrm{O} 2$ & OI & $\mathrm{O} 2$ & $\mathrm{O} 4$ & - \\
\hline $2010-[2016]$ & $3 \mathrm{I}$ & IO & 07 & OI & $\mathrm{I} 3$ & $\mathrm{I} 2$ & $\mathrm{O} 4$ & $\mathrm{O} 2$ & $\mathrm{O} 4$ & - & $\mathrm{O} 2$ & - & $\mathrm{O} 4$ & OI \\
\hline Total por estado & 94 & 24 & I2 & OI & 48 & I4 & 06 & $\mathrm{O} 2$ & 06 & $\mathrm{O} 2$ & $\mathrm{O} 3$ & $\mathrm{O} 2$ & O8 & OI \\
\hline Total por regiāo & I3I & & & & 68 & & & 15 & & & & & 9 & \\
\hline Total geral & 223 & & & & & & & & & & & & & \\
\hline
\end{tabular}

Fonte: Mortatti (2003; 20I2) e Banco de Teses e Dissertaçôes da Capes.

I3 Conforme consta no site da Capes, o “[...] Mestrado Profissional (MP) é uma modalidade de Pós-Graduação stricto sensu voltada para a capacitação de profissionais, nas diversas áreas do conhecimento, mediante o estudo de técnicas, processos, ou temáticas que atendam a alguma demanda do mercado de trabalho. Seu objetivo é contribuir com o setor produtivo nacional, no sentido de agregar um nível maior de competitividade e produtividade a empresas e organizaçóes, sejam elas públicas ou privadas." (Brasil, s.d., s.p.). Os mestrados profissionais são regulamentados, no Brasil, pela Portaria Normativa no ${ }^{\circ}$ 17, de 28 de dezembro de 2009. Disponível em <http://www. capes.gov.br/avaliacao/sobre-a-avaliacao/mestrado-profissional-o-que-e>. Acesso em 29 abr. 2015. 
Entre as décadas de 1970 e 1990, as teses sobre literatura infantil foram produzidas em cursos/programas de pós-graduação de universidades localizadas nos estados de São Paulo, Rio de Janeiro, Rio Grande do Sul, Minas Gerais e Paraíba, nessa ordem de ocorrência. Na década de 2000 , com a expansão dos programas de pós-graduação no país, observa-se produção de teses sobre o tema em outros seis estados: Santa Catarina, Paraná, Pernambuco, Ceará, Rio Grande do Norte e Goiás. No entanto, apesar dessa expansão, verifica-se que, por quase trinta anos, a produçáo de teses sobre literatura infantil esteve concentrada em instituiçóes universitárias situadas nas regiôes Sudeste e Sul do país. Das 97 teses defendidas nesse período, 53,61\% foram em programas de pós-graduação da regiáo Sudeste e 36,08\%, em programas de pós-graduação da região Sul. Cabe destacar ainda que, desse total de teses na década de 2000, 43,3\% foram produzidos no estado de São Paulo.

Esse lento movimento de expansão na produçáo de teses de doutorado sobre literatura infantil nas diferentes regióes brasileiras acompanha movimento similar de expansão da pós-graduação no Brasil. Menciona-se, por exemplo, a não localização, até o momento, de tese sobre o tema produzida na região Norte, a qual também conta com o menor número de cursos de doutorado em áreas com potencial interesse nos estudos sobre literatura infantil.

Em relação às dissertaçôes sobre literatura infantil, nota-se uma distribuição por todas as regiōesgeográficas/estados brasileiros, desde a década de 1980, conforme quadro na página a seguir.

Os trabalhos produzidos na década de 1970 concentram-se em programas de pós-graduação das regiôes Sul e Sudeste. Em relação à década de 1980, encontramos trabalhos defendidos também nos programas de pós-graduação do estado da Paraíba, na Região Nordeste, e no Distrito Federal. 
$\mathrm{Na}$ década de 1990, essa diversificação é ainda maior. Localizamos trabalhos produzidos em outros II estados brasileiros: Paraná, Espírito Santo, Goiás, Mato Grosso, Bahia, Pernambuco, Rio Grande do Norte, Ceará, Piauí, Alagoas e Amazonas. Cumpre destacar que, na década de 1990, foi defendido o primeiro trabalho sobre literatura infantil produzido na regiáo Norte do país. Trata-se da dissertação de Maria das Graças Freitas Castro, defendida no programa de pós-graduação em Educação da Universidade Federal do Amazonas, em 1993, e intitulada $A$ poesia como fator de desenvolvimento da sensibilidade no ensino das séries iniciais do primeiro grau.

Em relação às décadas de 2000 e 2010 , verificam-se dissertaçóes na quase totalidade dos estados brasileiros e no Distrito Federal, à exceção apenas dos programas de pós-graduação nos estados de Amapá e Roraima. Apesar dessa expansão, tal como ocorre com as teses, a maior concentração dos trabalhos de mestrado se encontra na regiáo Sudeste. Das I.023 dissertaçóes, 478 foram defendidas em programas de pós-graduação dos estados de Sáo Paulo, Rio de Janeiro, Minas Gerais e Espírito Santo, totalizando $46,72 \%$ dos trabalhos nesse nível de titulaçáo acadêmica. Em seguida, os estados da Regiáo Sul concentram o maior número, 298, o que totaliza 29,13\% das dissertaçôes localizadas. 
Produção acadêmica brasileira sobre literatura infantil...

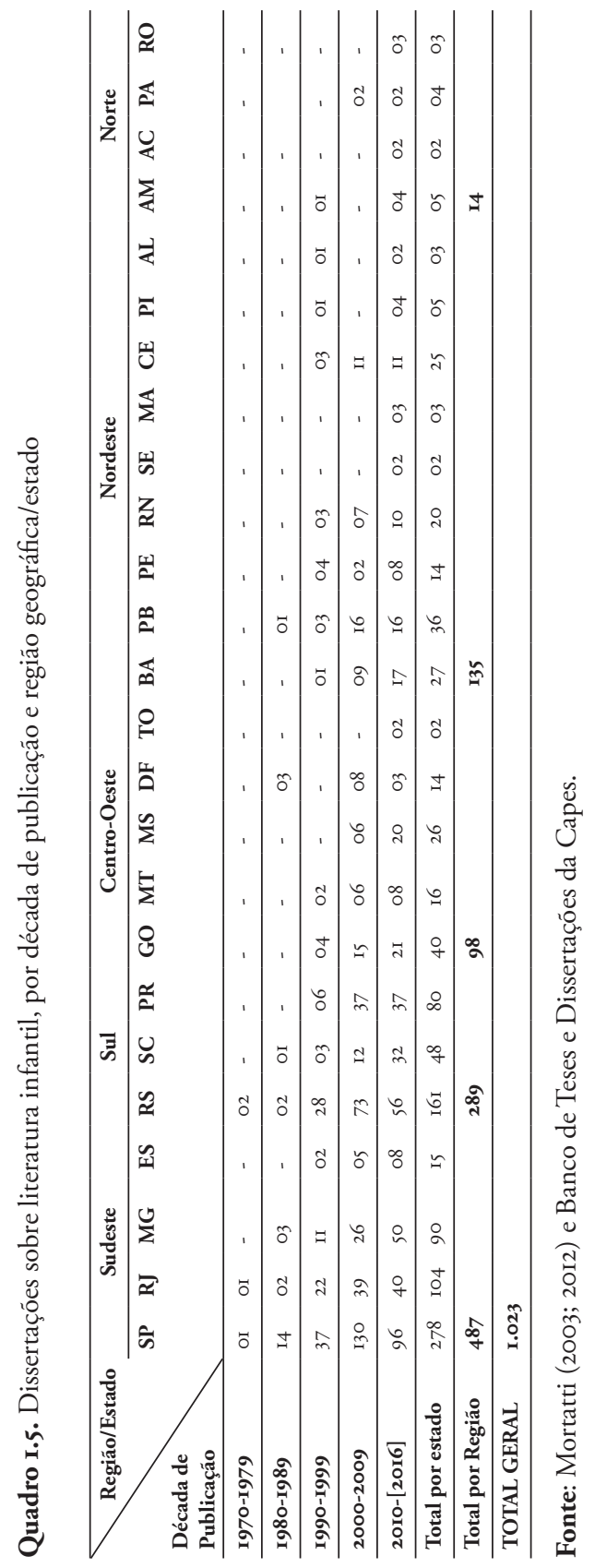


No caso dos quatro estados (São Paulo, Rio de Janeiro, Rio Grande do Sul e Minas Gerais) com maior número de teses e dissertaçôes sobre literatura infantil, cabe destacar que, neles, se encontram instituições universitárias e programas de pós-graduação mais antigos e com maior tradição no desenvolvimento de pesquisas acadêmicas sobre o tema: Universidade de São Paulo (USP), Pontifícia Universidade Católica de São Paulo (PUC-SP), Universidade Estadual Paulista (Unesp) ${ }^{\mathrm{I4}}$ e Universidade Estadual de Campinas (Unicamp), todas situadas no estado de Sáo Paulo; Universidade Federal Fluminense (UFF), Universidade do Estado do Rio de Janeiro (UERJ), PUC-RJ e Universidade Federal do Rio de Janeiro (UFRJ), no estado do Rio de Janeiro; PUC-RS e Universidade Federal do Rio Grande do Sul, no estado do Rio Grande do Sul; e Universidade Federal de Minas Gerais (UFMG), Universidade Federal de Juiz de Fora (UFJF) e Centro Superior de Educação de Juiz de Fora (CES/JF), as três no estado de Minas Gerais.

\section{I.5. Avanços e contradiçóes da produçáo acadêmica brasileira sobre literatura infantil}

As consideraçóes e os dados apresentados possibilitam problematizar aspectos significativos dessa produção acadêmica. $\mathrm{O}$ crescimento quantitativo das teses e dissertaçóes sobre o tema,

\footnotetext{
I4 Entre as teses e dissertaçôes defendidas nos programas de pós-graduação da Unesp, destacamos as dez vinculadas ao GPHELLB, sob a orientação de Mortatti. Desde 1996 até a data de conclusão deste artigo, foram defendidas: entre 1996 e I999, uma tese e duas dissertaçóes no programa de pós-graduação em Letras, Unesp, Assis; e, entre 2000 e 20I6, seis teses (mais uma a ser defendida em 20I8) e quatro dissertações no programa de pós-graduação em Educação da Unesp, Marília. Vinculados a esse grupo, existem ainda textos de Mortatti e trabalhos em nível de graduaçáo, elaborados por integrantes do grupo, com a mesma orientadora: cinco relatórios de Iniciaçấo Científica e três trabalhos de conclusão de curso de Pedagogia. Dados sobre essa produção do GPHELLB encontram-se em Santos (2015).
} 
sua distribuição gradual por programas de pós-graduação de diferentes áreas do conhecimento, assim como por diferentes regióes geográficas do país, são indicativos de avanços importantes. No entanto, ao relacionar essas características aos movimentos de expansão da produção de livros de literatura infantil, de discussão de problemas e propostas relativas à leitura e à literatura infantil, de criação e expansão da pós-graduação no Brasil, é possível constatar também contradições no movimento de constituição desse campo de conhecimento.

Por um lado, os avanços podem ser considerados representativos do movimento (desejável e necessário) de interdisciplinarização da literatura infantil como objeto de investigação, em face de sua característica "multifacetada", decorrente da "condição de origem" dos textos desse gênero, de sua "unidade múltipla determinantemente constitutiva" (Mortatti, 2008). Por outro lado, também (e principalmente) revelam contradições dignas de investigação. Entre essas, talvez caibam as resultantes de um ponto de vista que abrange maior duração histórica, como as conjecturas formuladas a seguir.

O predomínio dos trabalhos na área de Letras, sobretudo nas décadas iniciais (1970, 1980) dessa produção acadêmica, indica um movimento inverso ao dos estudos sobre o tema, nas décadas anteriores, quando estavam vinculados à área de Educação e à criação da disciplina correspondente nos cursos de formação de professores primários. ${ }^{15}$ Nesse sentido, a preponderância da área de Letras e a discussão sobre a necessária esteticidade da literatura infantil podem ser entendidas como uma espécie de reação contra o momento anterior, em que o "belo estético" devia atender à finalidade instrucional, como uma busca do equilíbrio para a dupla função (útil e agradável) atribuída à literatura. E, nesse caso, o

\footnotetext{
I5 A esse respeito, ver Oliveira (20I5). Trata-se de uma publicação resultante de pesquisa vinculada ao GPHELLB.
} 
predomínio da área de Letras pode ser entendido como influência do processo de hegemonização da discussão nessa área, iniciada na década de 1980, mas que se estende até os dias atuais. Observe-se, por exemplo, que ainda é muito escassa a bibliografia brasileira sobre literatura infantil e que os mais recentes (publicados nas décadas de 1960-1980) dos textos clássicos já mencionados tornaram-se referência para os iniciantes ou veteranos no estudo do tema.

O fato de a área de Educação estar em segundo lugar na quantidade de trabalhos acadêmicos sobre o tema pode auxiliar na compreensão da aludida conjectura. Mas, ao mesmo tempo, pode ser indicativo de uma tendência à revitalização das finalidades instrucionais características da "literatura escolar" (a qual deu origem à literatura infantil brasileira), vinculada, atualmente, às urgências impostas pela implementação de políticas públicas para a Educação Básica, especialmente. Não há, porém, mera repetição. De forma inequívoca, as discussóes travadas pelos estudiosos da área de Letras fincaram raízes e, neste século XXI, ao lado dos debates empreendidos por estudiosos de outras áreas, amplificaram-se com a expansáo do mercado editorial e outros avanços tecnológicos, propiciando a edição primorosa de livros com textos verbais e não verbais, em vários suportes e mídias. Essas mudanças também vêm reconfigurando a "cadeia produtiva" da literatura infantil: autores, editores, educadores, pesquisadores, leitores previstos (crianças ou jovens) (Mortatti, 2008, p. 44).

$\mathrm{O}$ interesse no desenvolvimento de pesquisas em programas de pós-graduação de outras novas áreas de conhecimento, por sua vez, ao mesmo tempo que pode ser saudado como uma tendência ao reconhecimento da característica interdisciplinar do tema, talvez - e provavelmente - indique a crescente dispersão dos conhecimentos acumulados sobre a temática naquelas duas áreas predominantes. Essa conjectura também deriva do que se sabe sobre as 
atividades de muitos pesquisadores iniciantes, como, por exemplo, a pouca importância atribuída à revisão bibliográfica em teses e dissertaçóes, possivelmente justificada ou pelo mero desconhecimento de sua importância ou pelos estreitos prazos impostos à conclusão da pesquisa. Nesse caso, a dispersão por áreas de conhecimento pode apontar para uma tendência à fragmentaçáo do campo, que, sem o devido acúmulo de conhecimentos (em comparação a outros, como, por exemplo, alfabetização), tenderá a não ser considerado como tal.

Deve-se observar ainda que, hoje, as motivaçóes e finalidades da literatura infantil (assim como as da literatura em geral) são muito diferentes. Por exemplo, mencionamos o caso de recentes pesquisas sobre literatura infantil desenvolvidas por pesquisadores do campo da História da Educação, os quais têm questionado a interpretação da obra de Monteiro Lobato como "ato fundador" da literatura infantil brasileira. Esses pesquisadores defendem a precedência, como fundadora do gênero no Brasil, da obra Saudade (I919), de Thales de Andrade. Esse questionamento, porém, não parece ser exatamente uma

[...] disputa de interpretação, de acordo com os mesmos critérios, mas a proposiçáo de novo ponto de vista, com base nas características do movimento histórico da literatura infantil ao longo do século $\mathrm{XX}$, quando sua inserção na escola e sua relaçáo direta com esse contexto foram se tornando desejáveis (não mais questionáveis). Talvez, no atual contexto político e econômico do Brasil, não faça mais tanto sentido discutir características estéticas como determinantes da qualidade da literatura infantil, ou, talvez [de outros pontos de vista], não se considerem importantes a interdisciplinaridade desses textos nem a correspondente necessidade de abordagens interdisciplinares para seu estudo (Mortatti, 2015). ${ }^{16}$

I6 Nessa citação, tem-se também uma tradução livre do original em inglês. 
Em que pesem as características específicas das pesquisas nesse campo e sem incorrer no equívoco de generalizaçóes indevidas, é preciso, porém, alertar para o fato de que problemas e contradiçôes como os mencionados são, em grande parte, semelhantes aos verificáveis na produção acadêmica brasileira em outras áreas e campos de conhecimento.

À produção de teses e dissertações sobre literatura infantil, é possível aplicar, por exemplo, reflexóes como as que formulamos relativamente à produção acadêmica sobre alfabetização:

[d] ispersão e disputas de enfoques; repetições de temas e abordagens "da moda"; ausência de problema de investigação, de consistente justificativa de relevância e pertinência científicas e sociais; ausência da devida revisão bibliográfica e de consistente e coerente referencial teórico-conceitual, dentre outros problemas, precisam ser acolhidos para reflexão, se almejamos avanços substanciais [...]. Para isso, impóe-se a necessidade de questionar se essa produção acadêmica [...] responde a perguntas cujas respostas ainda não se conhecem, se dialoga, de fato e de forma consequente, com o conhecimento acumulado sobre o tema (Mortatti et al., 20I4, p. 27).

E, também em relação à produção de teses e dissertações sobre literatura infantil, questiona-se se esses trabalhos acadêmicos

[...] indicam avanços em termos de produção de conhecimento sobre o tema, ou se indicam consolidação de tendência à reprodução de "verdades inquestionáveis", como forma de, submetendo-se a normas e prazos impostos por organismos reguladores, garantir obtenção de financiamento público e, sobretudo, de títulos acadêmicos. E, se concordássemos com os princípios da lógica produtivista, herdada do contexto de origem da pós-graduação e ainda vigente em versão aprimorada, também poderíamos questionar se as teses e disserta- 
çôes sobre [literatura infantil] têm contribuído para que a universidade brasileira se transforme em "centro criador de ciência e cultura" e se têm "impacto científico e social" que justifique os recursos públicos investidos na formação de pesquisadores e no desenvolvimento de suas pesquisas acadêmicas. Quantas teses e dissertações sobre [literatura infantil] resultam em "publicaçôes qualificadas"; quantas conseguem o "impacto social" pretendido por muitos doutorandos e mestrandos que almejam, com suas "pesquisas de intervenção" nas práticas pedagógicas ou nas políticas públicas, "resolver" os problemas da [educação] no Brasil?

De fato, produção de teses e dissertações sobre [literatura infantil] não é, em todos os casos, sinônimo de produção de conhecimento sobre o tema. Por esse problema, porém, não são responsáveis somente as novas geraçôes de pesquisadores em formação e seus orientadores. Deve-se buscar a compreensão das contradições [...] na herança de problemas seculares e, do ponto de vista do passado recente, dos $2 \mathrm{I}$ anos de silêncio impostos pelo regime político ditatorial, durante o qual se engendrou uma "ditadura da idiotia" (Mortatti, 2008), com base na qual se forma(ra)m geraçóes de brasileiros e seus formadores, da educação básica à pós-graduação (Mortatti et al., 20I4, p. 28).

\section{Consideraçóes finais}

Os avanços e as contradiçóes apontados também são indicativos dos desafios que se apresentam aos pesquisadores (de fato) interessados em compreender a produção de e sobre literatura infantil brasileira.

Se a expansão quantitativa torna possíveis a análise e a problematização dos aspectos destacados neste artigo, a diversidade/ dispersáo de temas de pesquisa e de áreas de conhecimento envolvidas, assim como a proximidade histórica do processo de produção das pesquisas, impóem outras necessidades urgentes. Den- 
tre essas necessidades, destacam-se: a atenção à definição de temas e objetos de pesquisa e, especialmente, para a construção de métodos e instrumentos adequados à especificidade desses relativamente novos temas de pesquisa e campo de conhecimento; a busca de compreensão do conhecimento em construção e suas implicaçóes para a pesquisa acadêmica, para a produção de livros de literatura infantil e para a formulação e a implementação de políticas públicas voltadas à leitura e à formação de leitores especialmente desse gênero literário.

Levando-se em conta os avanços, contradições e desafios apontados, esperamos que este artigo possa servir como incentivo para pesquisas mais amplas, do tipo "estado da arte"/"estado do conhecimento", características do estágio de "maturidade" do campo, de inegável importância para a avaliação do conhecimento acumulado, com vistas à identificação e à problematização de contradições e lacunas, assim como à proposição fundamentada de novos temas, objetos e abordagens teórico-metodológicas que propiciem avanços ainda necessários nesse campo.

\section{Referências}

ARROYO, Leonardo. Literatura infantil brasileira: ensaio de preliminares para sua história e suas fontes. São Paulo: Melhoramentos, 1968.

ASSIS, Vivianny Bessão. A contribuição de Leonardo Arroyo (1918-1985) para a história da literatura infantil brasileira (tese). Universidade Estadual Paulista, Marília, 2016.

AZEVEDO, Fernando. “A literatura infantil numa perspectiva sociológica”. Sociologia (Escola de Sociologia e Política), v. XIV, n. I, pp. 43-63, 1952.

BERTOLETTI, Estela Natalina Mantovani. Lourenço Filho e literatura infantil e juvenil. São Paulo: Unesp, 2012.

ESPÓSITO, Yara L. "Alfabetização em revista: uma leitura”. Cadernos de pesquisa, n. 80, pp. 2I-7, 1992. 
FRACCAROLI, Lenyra. Bibliografia de literatura infantil em língua portuguêsa. 2 ed. São Paulo: Editora Jornal, I955.

GATTI, Bernadete A. "Pós-graduação e pesquisa em educação no Brasil, I978198I". Cadernos de Pesquisa, n. 44, pp. 3-17, fev. 1983.

LAJOLO, Marisa e ZILBERMAN, Regina. Literatura infantil brasileira: história \& histórias. São Paulo: Global, 1984.

LOURENÇO FILHO, Manoel Bergstrôm. "Como aperfeiçoar a literatura infantil”. Revista Brasileira, Rio de Janeiro, v. 3, n. 7, pp. I46-69, 1943.

MACIEL, Francisca Izabel Pereira. "Alfabetização: pesquisas, dados, análise". In e FRADE, Isabel C. A. da Silva (orgs.). Alfabetização e seus sentidos: o que sabemos, fazemos e queremos? São Paulo: Unesp/Marília: Oficina Universitária, 20I4.

MAGNANI, Maria do Rosário Mortatti. "Entre a literatura e o ensino: um balanço das tematizaçôes brasileiras (e assisenses) sobre literatura infantil e juvenil". Miscelânea: Revista de Pós-Graduação em Letras: Teoria Literária, Literatura Comparada e Literaturas de Lingua Portuguesa, Assis, v. I, n. 3, pp. 247-57, 1998. MELLO NETO, Gustavo Adolfo R. O discurso especializado em literatura infantojuvenil no Brasil na década de so: da criança mitificada à atitude política (dissertação). PUC-SP, 1988.

MORTATTI, Maria do Rosário Longo. "Leitura crítica da literatura infantil”. Itinerários, Araraquara/SP, vv. I7-I8, pp. I79-87, $200 \mathrm{I}$.

. Ensino de língua e literatura no Brasil: repertório documental republicano. Marília, 2003 (digitado).

. "Literatura infantil e/ou juvenil: a 'prima pobre' da pesquisa em Letras?". Guavira Letras, UFMS, v. 6, pp. 43-52, 2008.

- "Contribuiçôes do GPHELLB para o campo da história da alfabetização no Brasil”. In __ (org.). Alfabetização no Brasil: uma história de sua história. São Paulo/Marília: Cultura Acadêmica/Oficina Universitária, 20II, pp. 69-94. - Bibliografia brasileira sobre história do ensino de língua e literatura no Brasil (2003-20II). Marília, 2012 (digitado).

- "Produção acadêmica brasileira sobre alfabetização: avaliação da qualidade e impacto científico e social”. In __e FRADE, Isabel C. A. da Silva (orgs.). 
Alfabetização e seus sentidos: o que sabemos, fazemos e queremos? São Paulo: Unesp/Marília: Oficina Universitária, 20I4a, pp. I3I-58.

. "Na história do ensino da literatura no Brasil: problemas e possibilidades para o século XXI". Educar em Revista, pp. 23-43, 20I4b.

. "Literature for primary school and education of republican citizens, in the 'Revista de Ensino' (São Paulo, Brazil), 1902-1918. History of Education \& Children's Literature (on-line), v. X, pp. 47-66, 2015.

e OLIVEIRA, Fernando Rodrigues. "Quatro décadas de produção acadêmica brasileira sobre literatura infantil: avanços, contradiçóes e desafios”. Revista Teias (UERJ, on-line), v. I6, pp. IO-32, 2015.

et al. "50 anos de produção acadêmica brasileira sobre alfabetização: avanços, contradiçôes e desafios". Interfaces da Educação, v. 5, pp. 6-3I, 2014. OLIVEIRA, Fernando Rodrigues. "A produção acadêmico-científica brasileira sobre literatura infantil e juvenil e a constituição de um campo de investigação". In DÍAZ, José María Hernández (org.). Formación de Élites y Educación Superior em Iberoamérica (Ss. XVI-XXI). Salamanca: Hergar, 2012.

. História do ensino da literatura infantil na formação de professores no estado de São Paulo (1947-2003). São Paulo: Cultura Acadêmica, 2015.

PASQUIM, Franciele Ruiz. "Lenyra Fraccaroli e bibliotecas infantis na história da educação brasileira”. Encontro Estadual de História, 23, Assis, 2016. Anais... ANPUH, 2016, pp. I-II.

PERROTI, Edmir. O texto sedutor na literatura infantil. São Paulo: Ícone, I986. SANTOS, Cassio Miranda dos. "Tradiçôes e contradiçôes da pós-graduação no Brasil”. Educação \& Sociedade, v. 24, n. 83, pp. 37-4I, ago. 2003.

SANTOS, Laís Silva Cassimiro. A produção sobre literatura infantil do GPHELLB - Grupo de pesquisa "História do ensino de lingua e literatura no Brasil" (I994-2014): estudo introdutório (trabalho de conclusão de curso). Universidade Estadual Paulista, Marília, 2015.

SOARES, Magda. Alfabetização no Brasil: o estado do conhecimento. Brasília: Inep Reduc, 1989.

e MACIEL, Francisca I. Pereira. Alfabetização. Brasília: Mec/Inep/ Comped, 2000. 
2

\title{
Literatura infantil brasileira: conceitos e problemas à luz dos estudos de Leonardo Arroyo e Cecília Meireles ${ }^{1}$
}

\author{
Márcia Cabral da Silva
}

\begin{abstract}
A Literatura não é, como tantos supõem, um passatempo. É uma nutrição. A Crítica, se existisse, e em relação aos livros infantis, deveria discriminar as qualidades de formação humana que apresentam os livros em condiçóes de serem manuseados pelas crianças. Deixando sempre uma determinada margem para o mistério, para o que a infância descobre pela genialidade da sua intuição.
\end{abstract}

O livro de ficção para crianças é de difícil conceituação. Livro para se ler, segundo o gosto da criança, ou livro para se ensinar a ler, circunscrito pela visão dominante de adultos e pedagogos? Trata-se de uma ambivalência nuclear que demarca o campo em seus primórdios e permanece, notadamente, atual.

Na historiografia da literatura infantil no Brasil, por um lado, o livro de ficção tem sido identificado como livro para instruir; por outro, visto como potencial objeto de entretenimento. De modo a se refletir sobre essa ambivalência em perspectiva histórica, adotou-se uma revisão conceitual em diálogo com estudiosos que se debruçaram sobre o assunto e apontaram inflexóes relevantes para o campo de estudo. A pesquisa, desenvolvida por Leonardo Arroyo (I918-1986), publicada em I968 e baseada em

I Este texto foi publicado na revista Teias, v. I6, n. 4I (20I5), e atualizado para este livro. 
diversas fontes documentais, é um marco importante. Em acréscimo, as conferências proferidas por Cecília Meireles (I9OII964) e reunidas em um livro nos anos I950, intitulado Problemas da literatura infantil, concorrem para noçóes originais, com vistas a se ampliar tal exame.

\section{I Literatura infantil brasileira: contribuiçóes de Leonardo Arroyo}

Nessa linha de consideração, deve-se ter em conta a pesquisa desenvolvida por Leonardo Arroyo, publicada em primeira edição em $1968^{2}$ e baseada em fontes documentais, como catálogos de livrarias e de bibliotecas, livros de memórias e relatos, entre outras.

Leonardo Arroyo era um homem do campo das letras. Conforme indica Coelho (I995), trabalhou como editor da Folha de São Paulo e como diretor do Departamento de Cultura da Prefeitura de Sáo Paulo, dedicando-se a diferentes pesquisas que, posteriormente, foram publicadas em forma de livros. Em acréscimo, na década de I940, dedicou-se a adaptaçôes de contos clássicos para a Coleção Encantada (Editora Melhoramentos). Nota-se, portanto, que sua pesquisa, relacionada a preliminares para a história e às fontes da literatura infantil no Brasil, ancorava-se, sobretudo, em vertentes sólidas extraídas do campo de atuação intelectual no qual se inseria.

Em que pese a dificuldade de se localizarem catálogos de editoras e de bibliotecas, cuja preservação, com frequência, tem sido negligenciada nos acervos do país, o estudioso pôde suprir essa lacuna apoiando-se em depoimentos memorialísticos, ensaios sociológicos e, nos limites de seu inventário, no exame dos livros infantis que pôde localizar. A metodologia, embora apre-

2 Arroyo (I968); Arroyo (20II). Este estudo baseia-se na primeira e na última edições. 
sente alguns hiatos, como, por exemplo, a ausência de uma antologia de textos ficcionais infantis - prevista no plano inicial da obra - e a avaliaçáo de obras contemporâneas à época da escrita do autor, teve o mérito de indicar fontes preliminares, para que outros estudos nesse campo pudessem ocorrer no futuro. ${ }^{3}$

As reminiscências das leituras da infância de Manuel Bandeira, ${ }^{4}$ registradas em Itinerário de Pasárgada (Bandeira, 1954), são um exemplo interessante de como a metodologia selecionada por Leonardo Arroyo pode contribuir para a recuperação de fontes documentais de outros tempos:

O meu primeiro contato com a poesia sob a forma de versos terá sido provavelmente em contos de fadas, em histórias da carochinha, no Recife, depois dos seis anos. Pelo menos me lembro nitidamente do sobrosso que me causava a cantiga da menina enterrada viva no conto "A madrasta" [...]. Procuro me lembrar de outras impressóes poéticas da primeira infância e eis que me acodem os primeiros livros de imagens: João Felpudo, Simplício olha pro ar, Viagem à roda do mundo numa casquinha de noz. Sobretudo este último teve influência muito forte em mim; por ele adquiri a noção de haver uma realidade mais bela, diferente da realidade quotidiana, e a página do macaco tirando cocos para os meninos despertou o meu desejo de evasão. No fundo, já era Pasárgada que se anunciava (pp. 9-II).

No relato do poeta, verificam-se elementos relevantes para a compreensão da mencionada metodologia: de um lado,

3 O estado da arte dos conceitos a respeito da historiografia da literatura infantil brasileira é vasto. Nos limites deste estudo, remeto a alguns outros que guardam filiação estreita com a matriz inaugurada por Leonardo Arroyo: Lajolo e Zilberman (1986); Lajolo e Zilberman (I994); Coelho (199I), por trazerem referências explícitas ancoradas na pesquisa do autor.

4 Manuel Carneiro Sousa Bandeira Filho (Recife, I9/04/1886-Rio de Janeiro, I3/10/1968). 
acentua-se o resgate das influências extraídas da tradição oral e dos tipos de livro infantil que circulavam na sociedade da época: João Felpudo, Simplício olha pro ar, Viagem à roda do mundo numa casquinha de noz. Em acréscimo, observam-se as impressôes rememoradas sobre a experiência com a literatura na visão de uma criança: "[...] adquiri a noção de haver uma realidade mais bela, diferente da realidade quotidiana, e a página do macaco tirando cocos para os meninos despertou o meu desejo de evasão". Não bastasse o desenho das impressões delineado, o depoimento do poeta faculta, de outra parte, a possibilidade de se refletir sobre os modos de apropriação do material literário por parte do pequeno leitor em formação: a leitura causava-lhe medo, desejo de evasão, impressóes poéticas. Acentua-se, pois, uma perspectiva cara aos estudos tanto no âmbito da sociologia da leitura como da história cultural no que diz respeito às possibilidades de apropriação dos impressos. ${ }^{5}$

Nessa direção interpretativa, convém lembrar que a leitura é uma atividade cultural radicada na história. São, portanto, inúmeras e variadas as comunidades interpretativas possíveis de mapeamento no que diz respeito à apropriação dos livros de ficção no período da infância. É nesse sentido que os relatos de leitores-autores ou de leitores comuns auxiliam na mencionada metodologia de compilação e de interpretação de fontes, como observa Leonardo Arroyo, em seu rigoroso ensaio.

De Os três mosqueteiros e de contos folclóricos extraídos da densa literatura oral em contexto brasileiro, por exemplo, dá-nos notícia a poetisa Cecília Meireles (I994), nascida em I90I:

Sempre gostei de livros e, além dos livros escolares, li os de história infantil e os de adultos: mas estes não me pareciam tão interessantes,

5 Entre os trabalhos que abordam o conceito de apropriação relativo ao impresso, observam-se, em particular, os estudos de Chartier (1990, 1996 e 1999); Certeau (1991); Silva (2009). 
a não ser, talvez, Os três mosqueteiros, numa edição monumental, muito ilustrada, que fora de meu avô. Aquilo era uma história que não acabava nunca; e acho que esse era o seu principal encanto para mim $[\ldots]$.

Mas, se antes de saber ler já gostava de brincar com livros, antes de brincar com livros, gostava de ouvir histórias. Minha pajem, uma escura e obscura Pedrina, que sobrevivera (embora náo por muitos anos) à onda de sucessivas mortes que arrebatou toda a minha família, foi a companheira mágica da minha infância. Ela sabia muito do folclore açoriano, e sabia adivinhaçóes, cantigas, fábulas etc. (p. 83).

Estabelecida a metodologia para a coleta dos dados, Leonardo Arroyo detém-se, em seguida, nas reflexóes sobre a gênese do livro infantil no mundo ocidental. Anotaria, a esse respeito, uma premissa curiosa. A seu ver, questóes relativas à filiação das histórias ou mesmo aos temas já estariam bem equacionadas do ponto de vista de uma tentativa de sistematização. Entretanto, à época, a complexidade ainda permanecia, em grande medida, circunscrita ao delineamento técnico-pedagógico relativo à literatura infantil, por sua condição afeita a mudanças no espaço e na cultura humana.

Note-se que, ainda segundo o estudioso, se observadas as ediçôes modernas de As mil e uma noites, dos contos clássicos, parece que os temas náo passam por grandes variaçóes. No entanto, o tratamento, o estilo e o modo de contar as histórias guardariam estreita associação com a concepção de infância em voga e até mesmo com os valores postos a serviço de sua educação. Em sua exposição, o estudioso reflete sobre a concepção corrente de criança como um ser em miniatura, adulto em tamanho pequeno, sendo, portanto, conformada por aquele ângulo no que diz respeito a gosto, 
escolhas e, sobretudo, fisionomia dos livros infantis. Essa, sim, pode ser pensada como a dimensão mais complexa relacionada à definição de literatura infantil. Portanto, em que medida é possível conciliar fruição da arte literária com ordenamento e moralização por parte dos adultos? Como a escola - instituição cujos pressupostos baseiam-se, em grande medi$\mathrm{da}$, em educar a criança para responder aos valores vigentes - lograria emancipá-la, consoante a perspectiva estética, conforme percebia Manuel Bandeira, apoiado em uma sensibilidade própria da criança, ao se confrontar com as primeiras leituras de sua infância?

Os laços estreitos entre material literário e destinação instrutiva não é uma questão menor, quando observadas as primeiras décadas do período republicano - momento em que se acompanha uma circulação em ascendência dos livros ficcionais e escolares destinados às crianças no Brasil, a par de um ideário civilizador apoiado, em grande medida, na instrução. Para ficar em um estudo de caso que póe em relevo a literatura infantil e o mercado editorial sob a égide do binômio entreter e instruir, note-se a Biblioteca Infantil (Livraria Quaresma Editora). ${ }^{6}$

6 A respeito da relevância dos livros que circularam pela editora destinados tanto a crianças como ao público em geral, conferir, em especial, o estudo de El Far (2004). Sobre a importância do projeto mais amplo da Livraria Quaresma Editora, verificar, em acréscimo, Hallewell (1985). 
Bibliotheca da Livraria Quaresma

Histórias da Avósinha. Livro para crianças. Contendo maravilhosa collecção de contos populares, moraes e proveitosos de vários paizes, traduzidos uns, e outros apanhados da tradicção oral. (1936)

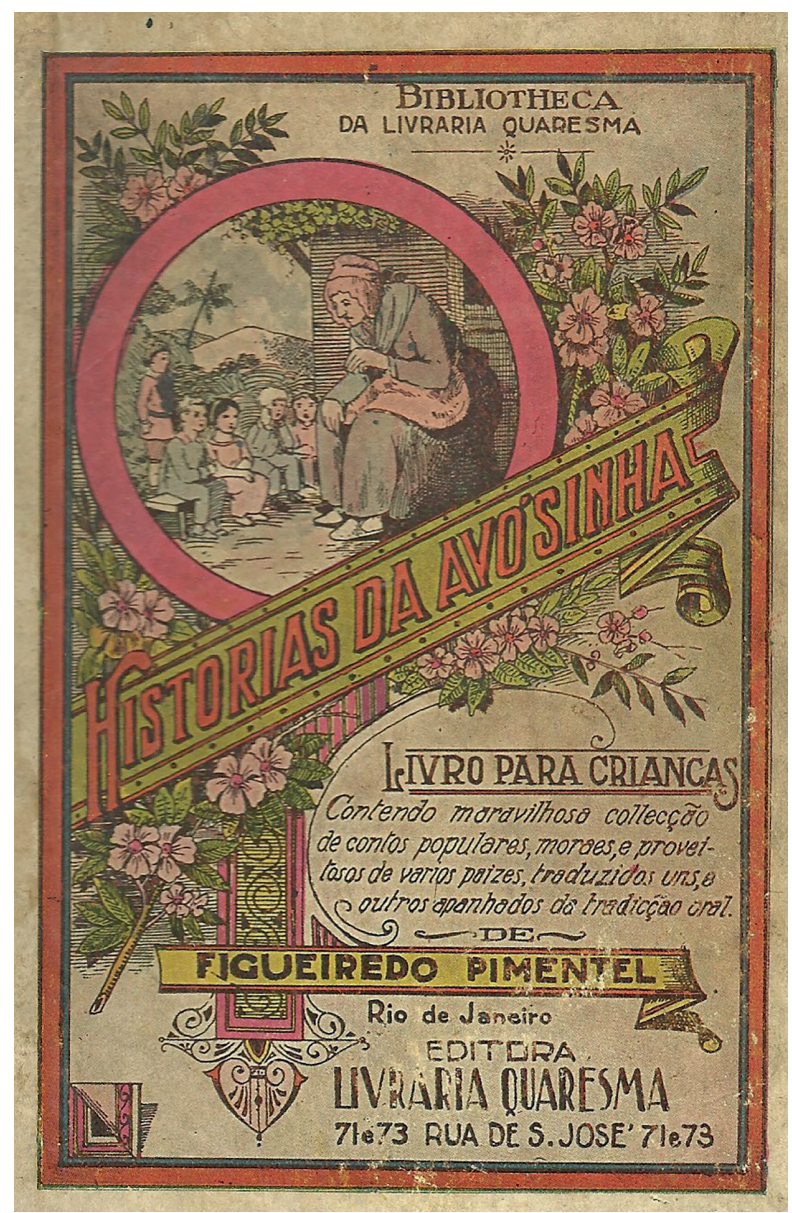

Figura 1: Histórias da Avósinha, Rio de Janeiro, Editora Livraria Quaresma, 1936. Bibliotheca da Livraria Quaresma 
A Livraria Quaresma Editora ou Livraria do Povo (rua São José, 65-67) destacava-se, no último quartel do século XIX, pela produção de livros baratos voltados para o povo, assim como de livros destinados a crianças, contos adaptados para a realidade brasileira, de conteúdo moral, histórias proveitosas e piedosas de vários países, algumas traduzidas e outras colhidas da tradição oral.

A primeira ocorrência desses livros localizada no periódico O Paiz, em I894, consiste no título Contos da carochinha. No curto intervalo de dois anos, contudo, registram-se, no mesmo periódico, reediçôes de Contos da carochinha, notas críticas sobre o projeto editorial e o lançamento de outros títulos: Contos da avózinha, Histórias do Arco da Velha, Os meus brinquedos, Histórias da Baratinha. Desse modo, em novembro de 1896 , já não se registram mais apenas anúncios contendo títulos avulsos. Nesse momento, a Livraria Quaresma \& C. - Livreiros Editores anuncia uma biblioteca completa: "Bibliotheca Infantil, dedicada especialmente às crianças".

Para dirigi-la, Pedro da Silva Quaresma convidou o jornalista e escritor fluminense Alberto Figueiredo Pimentel (I869-I9I4). ${ }^{7}$ Pimentel não era um mero desconhecido, visto que, em I893, lançara um livro com viés sensacionalista, $O$ aborto, considerado leitura para homens, e, mais tarde, em 1907, passara a ser o responsável pela seção "Binóculo" do periódico Gazeta de Notícias, atividade que parece consagrá-lo como cronista social de seu tempo.

7 Conferir verbete em Menezes (1969). 


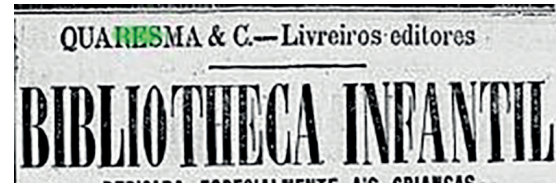

DEOICADA ESPECIALHENTE N'S CRIANCYAS

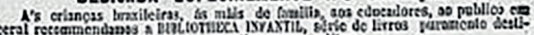

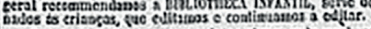

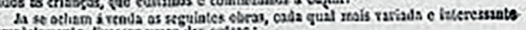
CONTOS DA CAROCIIIIIA

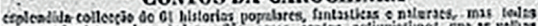

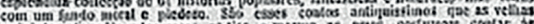

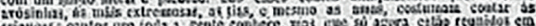

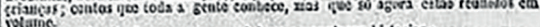

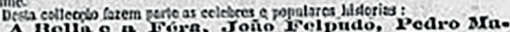

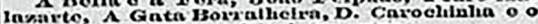

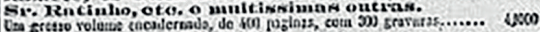
IIISTORIAS DA AVÓSINIL

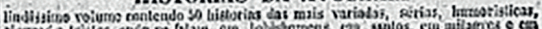

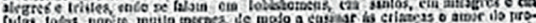
hias, 10as, ponts,

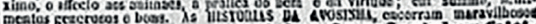

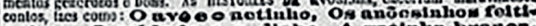
colros. O nolanao o o alabo, A catinha branon.

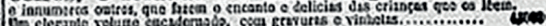

IIISTORIAS DO ARCO DA VEL î

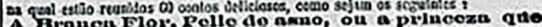
ponmula tres yestlos, Nondo um da cor do tompo outro dn oor do mol, o o toroesro da cor da lun. buxro o o bol. A inítorlas do Paqueno Polosnx. de Pequonn Polorux. O alralnto quo matarn wote

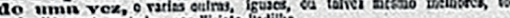

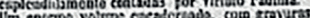

4000 OS MEUS BRINQUEDOS

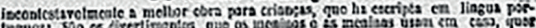

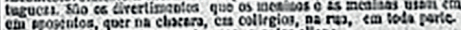

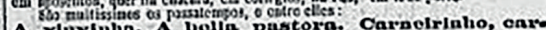
nolrío. Amirolia. O piquo. O chlooto quolmndo. netc., ct:. Ammitoila.

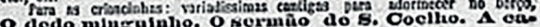
dofrin a oto oto.

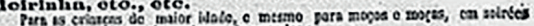

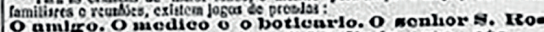
que. On wamento ocoulto. A boxlinila, ote. oto.

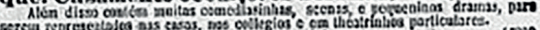

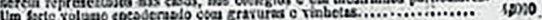
IIISTORIAS DA BANATINIA

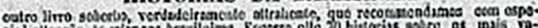

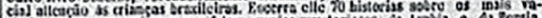

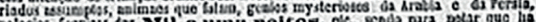

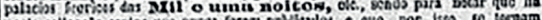

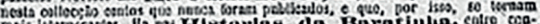
mais itsrersidas. Ha nas do Pedro Mraluzarto. 0

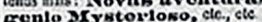

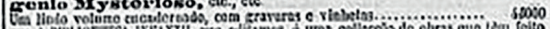

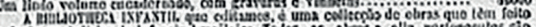

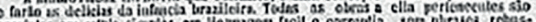

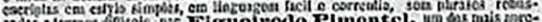

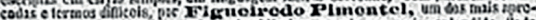

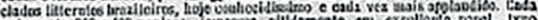

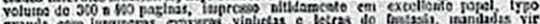
grande, cona capesialneas

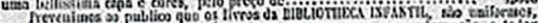

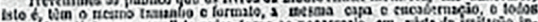

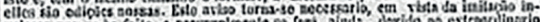

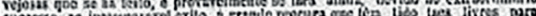
LLYBARII OO POV, RUA OE S. JOSE' HS. 65 E 67

Figura 2: O Paiz (12/11/1896 - ed. 04424, página 8) - Hemeroteca Fundação Biblioteca Nacional 
Do ponto de vista das ilustraçóes, a biblioteca contou com a colaboração do desenhista e caricaturista Julião Machado, ${ }^{8}$ como se lê na folha de rosto de Histórias da Avósinha (1936): "Obra illustrada com I3I gravuras desenhadas por Julião Machado". Em seu estudo, Herman Lima (1963) sublinha as seguintes referências, entre outras:

Juliáo foi, na verdade, quem trouxe ao humorismo nacional o gosto pelo desenho decorativo e pela legenda de espírito, de cunho eminentemente francês, pois a sua tendência sempre foi mais para a crítica psicológica, de fundo intelectual, do que para a pura deformação física da humanidade. Foi, também, o primeiro a adotar, nas suas publicaçôes, os processos gráficos do zinco e da fotografia, abrindo, assim, novos e mais amplos horizontes ao periodismo humorístico e elegante do Brasil (p. 16).

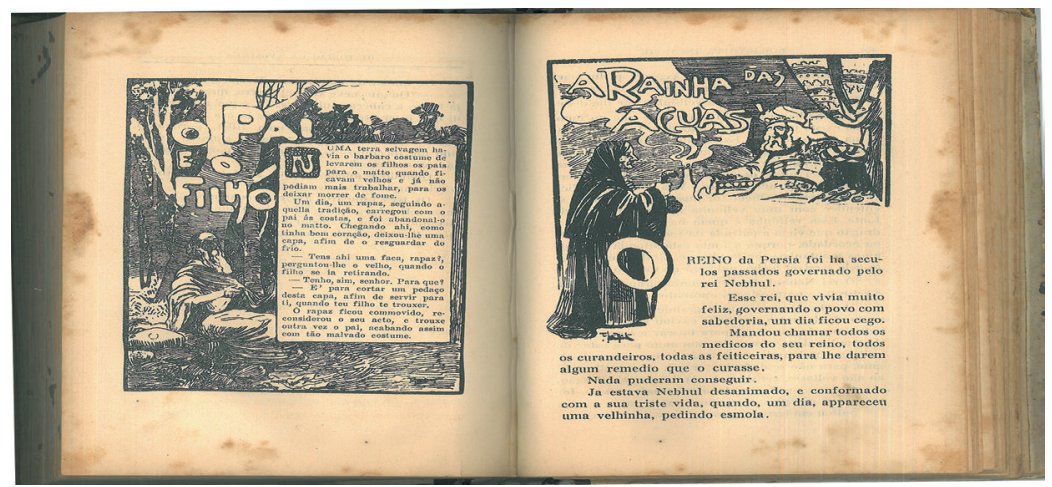

Figura 3: História da Avósinha (1936). Ilustrações de Juliāo Machado.

8 Juliāo Machado (São Paulo de Luanda, Angola, I863/Lisboa, Portugal, I930), desenhista e caricaturista ativo no Rio de Janeiro entre I894 e I920. Verificar informaçôes adicionais em Lima (1963) e Ayala (1973). 
O ilustrador também distinguia o projeto editorial da coleção de livros infantis, por ser considerado um caricaturista de destaque da imprensa da época, tendo colaborado, inicialmente, com Gazeta de Notícias, mais tarde em A Cigarra (que fundou em I895, com Olavo Bilac), A Bruxa (da qual foi um dos fundadores, com João Laje e Olavo Bilac, em I896), Jornal do Brasil, O País, Jornal do Commercio, A Noite e D. Quixote. Alberto Figueiredo Pimentel lançava-se, pois, na adaptação e na organização de uma biblioteca destinada a crianças contendo livros ilustrados com requinte e que foram reeditados pela Livraria Quaresma Editora até os anos 1960 .

A destinaçáo dos livros a pequenos leitores aparece reiterada pelo subtítulo inserido na capa e na folha de rosto de Histórias da Avósinha (1936): "livro para crianças". A partir do estudo desenvolvido por Arroyo (1968, 20II), sabe-se que eram enredos extraídos da tradição oral e dos contos populares. De que forma a destinação, entáo, facultaria um modo especial de tratamento à matéria literária? Vamos encontrar importantes indícios, desde o prefácio da primeira edição de Histórias da Avósinha, datada de I896 - ou seja, considerando-se a edição de 1936, examinada nos limites deste estudo, já se passam mais de três décadas de laços ainda bem firmes entre fruir e moralizar via arte literária destinada à infância:

Prefácio da I ${ }^{\mathrm{a}}$ edição

Pela terceira vez editamos um livro de contos para crianças. Animou-nos tal comettimento o extraordinário successo dos anteriores Contos da carochinha e Histórias do arco da velha - que obtiveram exito extraordinário, raro, nos annaes da livraria brasileira. Em verdade, ambos esses livros - dizemol-o com orgulho - vieram preencher sensivel lacuna: nelles estão reunidos muitissimos contos populares, que andavam espalhados exclusivamente na tradição oral, passando de geração em geração, sem no emtanto nunca haverem sido collecionados 
e escriptos. Continuamos hoje a série tão auspiciosa e brilhantemente encetada, publicando este terceiro volume - Histórias da Avósinha [...]. As crianças brasileiras, ás quaes destinamos e dedicamos esta série de livros populares, encontrarão nas Histórias da Avósinha agradável passatempo, alliado a liçóes de moralidade, porque taes contos, apparentemente frivolos, encerram sempre um fundo moral e piedoso (Pimentel, 1936, pp. 9-10, grifos nossos).

Para além das liçóes de moralidade explícitas no endereçamento às crianças brasileiras, há de se interrogar, por outro lado, como os contos populares acentuados na perspectiva da tradição delineada no estudo de Leonardo Arroyo (I968; 20II), passados de geração em geração, com feição e marcas de oralidade, configuraram-se em matéria escrita e em um suporte tão diferenciado quanto aqueles circunscritos pela fisionomia dos contos orais. Os temas clássicos são, de início, adaptados nos títulos com referência aos bons juízes ou aos meninos exemplares, à magia e ao encanto como esteio da boas açóes; das fábulas, como da onça e da raposa ou do cágado e do urubu, como uma lição de vida a ser considerada. ${ }^{9}$ A título de exemplificação desse tipo de ideário em Histórias da avósinha, observe-se o curto conto a seguir:

9 O livro examinado contém o seguinte conteúdo, identificado no índice organizado e inserido ao final dos contos: "Prefácio da nova edição", p. 5; "Prefácio da I ediçâo", p. 9; "O companheiro de viagem", p. II; "O avô e o netinho", p. 29; "O soldado e o diabo", p. 33; "O violino mágico", p. 39; "O miudinho", p. 43; "O sargento verde”, p. 49; "O patinho aleijado", p. 55; "O besouro de ouro", p. 63; "O moço pellado", p. 73; "Os três cavalos encantados”, p. 83; "História de um pintinho", p. 93; "O papagaio dourado", p. IOI; "O moleque de carapuça dourada", p. III; "A onça e o cabrito", p. I23; "O afilhado do diabo", p. I3I; "O príncipe enforcado”, p. I4I; "A princesa dos cabelos de ouro", p. I5I; "O peixe encantado”, p. I75; “O pássaro mavioso”, p. I83; "Joaquim, o enforcado", p. I89; "O príncipe querido", p. 199; "O anjo da guarda”, p. 215; "A casa de maribondos", p. 223; "O macaco e o moleque", p. 227; "O bom juiz", p. 23I; "A moça encontrada no mar", p. 233; "As três princesas encantadas", p. 24I; "Os anôes mágicos”, p. 247; "Aventuras de um jabuty", p. 255; "A gatinha branca", p. 259; "O dr. Grillo", p. 277; "O grande advogado", p. 28I; "Os anōesinhos feiticeiros", p. 285; "A casa mal-assombrada”, p. 29I; "Aventuras do Zé Gallinha”, p. 295; "O 


\section{O PAI e O FILHO}

Numa terra selvagem havia o bárbaro costume de levarem os filhos os pais para o matto quando ficavam velhos e já não podiam mais trabalhar, para os deixar morrer de fome. Um dia, um rapaz, seguindo aquella tradição, carregou com o pai ás costas, e foi abandonál-o no matto. Chegando ahi, como tinha bom coração, deixou-lhe uma capa, a fim de o resguardar do frio. - Tens ahi uma faca, rapaz? perguntou-lhe o velho, quando o filho se ia retirando. - Tenho, sim, senhor. Para que? - É para cortar um pedaço desta capa, afim de servir para ti, quando teu filho te trouxer. O rapaz ficou commovido, reconsiderou o seu acto, e trouxe outra vez o pai, acabando assim com tão malvado costume (Pimentel, I936, p. 318). ${ }^{\text {Io }}$

Em realidade, os textos ficcionais adaptados, à época, para a infância pela Livraria Quaresma Editora, examinados no livro Histórias da avósinha (1936), são traduções bem-sucedidas de contos populares ou histórias curtas inventadas, que visavam estimular a imaginação. São eloquentes os relatos memorialísticos que falam de evasão, como as memórias de Manuel Bandeira, registradas em Itinerários de Pasárgada, indicam.

No entanto, as adaptaçôes dos contos não perdiam de vista, do mesmo modo, a associação do divertimento com os preceitos morais, como podemos identificar na conclusão do pequeno conto examinado: "O rapaz ficou comovido, reconsiderou o seu acto, e trouxe outra vez o pai, acabando assim com tão malva-

kagado e o urubu", p. 307; "A princesa adivinha", p. 31I; "Os três ministros", p. 315; "O pai e o filho", p. 318; "A rainha das águas", p. 319; "A moça do lixo", p. 331; "A velha feiticeira”, p. 335; "A sapa casada", p. 34I; "A onça e a raposa", p. 347; "O annel magico", p. 349; "Um raio de sol”, p. 355; "A faquinha e a bilha quebrada”, p. 36r; "A burra e o seu burrinho", p. 369; "O vestido rasgado", p. 38I; "A alma do outro mundo", p. 387.

Io Agradeço a colaboração da bolsista de IC, Mariane Sousa, assim como da mestranda Mariana Elena Pinheiro dos Santos de Souza, pelo levantamento e o tratamento das fontes localizadas na Fundação Biblioteca Nacional, Rio de Janeiro. 
do costume". Segundo essa perspectiva, os temas, o enredo e os personagens também eram delineados à luz de uma estética de cunho moral. Em um momento de formaçáo da identidade nacional, como identificado na passagem do século XIX para o XX (Hansen, 20II), tratava-se de erigir a noção de pátria à luz das civilizaçóes ilustradas e letradas, a ser construída pelos futuros adultos, ou seja, pelas crianças brasileiras leitoras e em formação. Em razão desse projeto, Figueiredo Pimentel advertia os adultos, pais e professores:

As crianças brasileiras, ás quais destinamos e dedicamos esta série de livros populares, encontrarão nas Histórias da avósinha agradável passatempo, aliado a liçóes de moralidade, porque taes contos, aparentemente frívolos, encerram sempre um fundo moral e piedoso (Pimentel, 1936, p. 318).

Ou o que podia ser lido em um anúncio do jornal O Paiz, em dezembro de 1896 , acerca do conjunto de livros para crianças denominado Bibliotheca Infantil, assim como do lançamento de novo título da coleção: Histórias da baratinha.

As crianças que tanto apreciam a excelente Bibliotheca Infantil, editada pelos operosos livreiros Quaresma \& C., encontraráo hoje o $5^{\circ}$ volume dessa série, intitulada Histórias da Baratinha, que hoje mesmo será posto à venda. Como os antecedentes, é um livro de contos populares, morais e proveitosos de vários países, porém maior, pois contém 70 histórias e, bem impresso e com gravuras, até do notável artista Julião Machado. Já se sabe que hoje à rua de S. José será invadida por uma romaria de crianças, como sucede todas as vezes que os srs. Quaresma \& C. anunciam uma nova obra para a Infância (I896, p. 2). 
O tratamento dispensado aos livros destinados às crianças pela Livraria Quaresma Editora - populares, morais e proveitosos ilustra parte das dificuldades de conceituaçáo associadas ao livro de ficção infantil na primeira metade do século XX e aos problemas epistemológicos relativos ao campo de estudo com os quais deparou Leonardo Arroyo, a exemplo da crítica de seu tempo.

\subsection{Literatura infantil brasileira: a visão de Cecília Meireles ${ }^{\mathrm{II}}$}

Por outro lado, as três conferências proferidas por Cecília Meireles para os professores em Belo Horizonte e reunidas em livro nos anos 1950 sob o título Problemas da literatura infantil concorrem para noçóes originais, com vistas a ampliar o exame. Importa destacar a participação de Cecília Meireles em diversas esferas culturais e educativas: em 1932, assinou o Manifesto dos Pioneiros da Educação Nova; de 1930 a I933, redigiu crônicas e dirigiu a página da Educação do Diário de Notícias; em 1934, criou a primeira biblioteca infantil, no Pavilhão Mourisco. Também integrou a Comissão Nacional do Livro Infantil, criada em 1936, junto com professores e intelectuais, durante a gestáo do ministro de Educação e Saúde Gustavo Capanema. Essa trajetória concede à escritora lugar de destaque nos debates relativos à cultura e à educação por mais de três décadas.

Merece observação o preâmbulo do livro Problemas da literatura infantil, iniciando suas reflexôes inspirada por emblemáticos ideais humanistas:

Não se pretendeu aqui dar solução aos inúmeros problemas da literatura infantil. Pretendeu-se apenas insistir sobre a sua importância

\footnotetext{
II Entre outros levantamentos biográficos, conferir Lôbo (2002, pp. 237-47). Sobre a CNLIJ, conferir Santos (20II). Sobre as contribuiçóes de Cecília Meireles para a historiografia da literatura infantil, ver, em especial, Silva e Santos (2014) e, para verificar a participação de Cecília Meireles no campo da cultura, conferir, em particular, Almeida (20I4).
} 
e alguns dos seus variados aspectos. Se em tal assunto pudesse a autora exprimir alguma aspiração, talvez fosse a da organização mundial de uma biblioteca infantil que aparelhasse a infância de todos os países para uma unificação da cultura, nas bases do que poderia chamar um "humanismo infantil". $\mathrm{Na}$ esperança de que, se todas as crianças se entendessem, talvez os homens não se hostilizassem (Meireles, 1984, pp. 15-6).

Por meio desse estudo, a autora indicava fontes semelhantes às apontadas por Leonardo Arroyo, de um lado acentuando a literatura oral, os contos clássicos, e, de outro, lembrando a possibilidade de se postular a universalização da arte literária destinada à criança.

Tudo quanto se aprendia por ouvir contar hoje se aprende pela leitura. E, examinando-se boa parte dos livros - ainda os melhores que as crianças utilizam, aí encontramos as histórias da carochinha, que pertencem ao tesouro geral da humanidade: as mil e uma noites, as grandes narrativas que embalaram a antiguidade, como essa do Marinheiro Simbad - os contos que Perrault, Mme. D’Aulnoy, os irmãos Grimm recolheram, histórias vindas de outras coleçôes, fragmentos de epopeias -, tudo se comprime nesses livros, aproximando tempos e países, permitindo o convivio unânime dos povos, em poucos volumes (Meireles, 1984, p. 50, grifos da autora).

No que diz respeito à conceituação da matéria, sublinha uma vertente bastante original para a época no que diz respeito à posição da criança.

[...] em lugar de se classificar e julgar o livro infantil como habitualmente se faz, pelo critério comum da opiniáo dos adultos, mais acertado parece submetê-lo ao uso - náo estou dizendo à crítica - da criança, que, afinal, sendo a pessoa diretamente interessada 
por essa leitura, manifestará sua preferência, se ela satisfaz ou não (Idem, p. 30).

A originalidade residia, portanto, em certa inversão de domínio sobre o gosto. Afinal, por mais de meio século no Brasil, o material literário destinado às crianças passara pela avaliação dos adultos, que adaptavam conteúdos, temas e suportes, valendo-se de um status de subordinação do gosto dos pequenos leitores. No entanto, Cecília Meireles, em suas conferências para os professores, advogava uma mudança importante, ou seja, a necessidade de fazer avançar o debate por meio do exame da recepção das obras pelo leitor infantil.

É necessário lembrar que a ideia de inquéritos e entrevistas no que diz respeito às primeiras experiências de leitura literária já fora pensada por outros estudiosos. ${ }^{\mathrm{I}}$ No prefácio à primeira edição, Leonardo Arroyo (1968) cita um importante trabalho de atualização realizado por Lenyra C. Fraccaroli, Bibliografia de literatura infantil em lingua portuguesa, que abrange até o ano de I95I. Nesse trabalho, registram-se obras, autores e sínteses temáticas, com a respectiva idade da criança a que se destina o livro. Segundo Leonardo Arroyo, essa idade foi aferida pela média obtida das idades das crianças que leram cada um dos exemplares citados na bibliografia. Entretanto, a sistematização dos resultados e até mesmo a incorporação desses dados à historiografia do livro infantil não parecem haver sido disseminadas de modo suficiente, com vistas a promover inflexóes expressivas na área.

Naquela ocasião, o debate original proposto por Cecília elevava ainda mais a condição da criança como leitora proficiente. Note-se que, ao recuperar a qualidade dos textos tradicionais adapta-

I2 Conferir em Senna (1968). Em acréscimo, registre-se um inquérito sobre leituras infantis que contribuiu para a fundação da primeira biblioteca pública infantil (Biblioteca do Pavilhão Mourisco). A esse respeito, conferir estudo de Pimenta (20II). 
dos para as crianças, Cecília destacaria, no quadro do século XIX, Alice no pais das maravilhas e Alice no país do espelho, de Lewis Carroll, como os textos mais interessantes. A seu ver, o autor do clássico inseriu elementos do maravilhoso, visto que Charles Perrault, Hans Christian Andersen e os irmãos Grimm já haviam recuperado elementos mágicos de um modo original. Não obstante a tradição crítica, o que mais lhe chamava a atenção nas histórias de Alice eram as passagens filosóficas e o uso frequente do nonsen$s e$, com possibilidades de inquietar adultos e crianças. Assim, para valorizar o lugar reservado à criança em relação àquele material, a escritora sublinhava que a qualidade da obra de Lewis Carroll havia passado pela avaliação da criança no momento de sua produção. E acentuava:

Antes de ser escrito, o livro de Lewis Carroll foi uma história falada, contada diretamente a três meninas. Pode-se presumir que elas colaborassem na narrativa, como costuma acontecer em tais casos, e ajudassem, com suas perguntas e observaçóes, a estabelecer o enredo e a desenvolvê-lo (Idem, p. IIo).

À metodologia proposta por Leonardo Arroyo, com vistas a recuperar material literário que divertiu e educou geraçôes de crianças, na passagem do século XIX ao XX e ao longo do XX, acrescentam-se as conferências da escritora Cecília Meireles.

Nesse contexto, com Leonardo Arroyo, revisitam-se os livros clássicos ao lado dos contos extraídos da literatura oral, os quais conformaram o campo da literatura infantil no Brasil. Além disso, a metodologia selecionada por ele, com base nos estudos culturais, auxilia, sobretudo, a se compreenderem as formas de apropriação do material ficcional de outros tempos, gestos tão difíceis de ser recuperados, como apontam os estudos na área de História da Leitura (Chartier, 1990; 1996; 1999). Manuel Bandeira, em Iti- 
nerário de Pasárgada, contribui, em especial, para a compreensão de como os textos memorialísticos facultam a recuperação de leituras da infância afastadas de nosso presente, como os livros João Felpudo, Simplício olha pro ar e Viagem à roda do mundo em uma casquinha de noz nos permitem avaliar.

Cecília Meireles, por sua vez, dirige-se aos professores para se manifestar sobre a importância dos livros ficcionais infantis na formação cultural e estética da criança. Os contos extraídos da tradição oral consistem no ponto de convergência entre os dois estudiosos, visto que, no delineamento do que podemos designar como fundamentos históricos da literatura infantil, há de se considerarem, com especial relevo, as adaptaçóes dos elementos próprios da tradição oral para os livros ficcionais destinados às crianças em contexto brasileiro. Verifica-se ainda, em diálogo com a autora, a necessidade de se levar em consideração o ponto de vista da criança, seja na produçáo dos livros, seja no momento da apropriação da leitura. Note-se que, na visão de Cecília Meireles, é preciso avaliar a qualidade da produçáo literária infantil segundo a apreciação dos destinatários - no caso em exame, o leitor infantil.

Se, por um lado, os estudos desenvolvidos por Leonardo Arroyo e Cecília Meireles já forneceram rica matéria para a escrita da historiografia da literatura infantil no Brasil, por outro, não nos parecem fontes esgotadas. É importante assinalar, inclusive, sua condição de estudos clássicos no campo da crítica de literatura infantil no Brasil. Nas palavras de Ítalo Calvino (1993), "um clássico é uma obra que provoca incessantemente uma nuvem de discursos sobre si, mas continuamente as repele para longe". E "os clássicos são livros que exercem uma influência particular quando se impóem como inesquecíveis e também quando se ocultam nas dobras da memória, mimetizando-se como inconsciente coletivo ou individual" (Idem, pp. II-2). 
Desse modo, a releitura de Literatura infantil brasileira: ensaio de preliminares para a sua história e suas fontes e Problemas da literatura infantil permitiu o exame de conceitos e problemas relativos ao livro de ficção destinado à infância brasileira que não cessam de nos provocar no tocante à produçáo de conhecimento na área. São, portanto, livros clássicos, conforme a acepção do termo.

Por último, espera-se instigar, com este estudo, contribuiçôes adicionais para a historiografia da literatura infantil no Brasil, assim como para o debate antigo e, ao mesmo tempo, táo contemporâneo que coloca em cena a criança, o livro de ficçáo infantil e sua educação.

\section{Referências}

ALMEIDA, Patrícia Vianna Lacerda de. Crônicas de Cecília Meireles: leitura e literatura em prol da renovação educacional (I930-1933) (dissertação). UERJ, 20I4.

AYALA, Walmir (org.). Dicionário brasileiro de artistas plásticos. Brasília: INL Ministério da Educação e Cultura, 1973, v. 3, p. I6. (Coleção Dicionários Especializados 5.)

ARROYO, Leonardo. Literatura infantil brasileira: ensaio de preliminares para a sua história e suas fontes. São Paulo: Editora Melhoramentos, 1968. . Literatura infantil brasileira. 3 ed. São Paulo: Unesp, 201 I.

BANDEIRA, Manuel. Itinerário de Pasárgada. Rio de Janeiro: Jornal de Letras, 1954.

CALVINO, Ítalo. Por que ler os clássicos. São Paulo: Companhia das Letras, 1993.

CERTEAU, Michel. de. A invenção do cotidiano: artes do fazer. Petrópolis: Vozes, I99I, v. I. 
CHARTIER, Roger. A história cultural: entre práticas e representações. Trad. Maria Manuela Galhardo. Lisboa: Difel/Rio de Janeiro: Bertrand Brasil, I990. . Práticas da leitura. Trad. Cristiane Nascimento. São Paulo: Estação Liberdade, 1996. . A ordem dos livros: leitores, autores e bibliotecas na Europa entre os séculos XIV e XVIII. Trad. Mary Del Priori. Brasília: EDUSP, I999.

COELHO, Nelly Novaes. Panorama histórico da literatura infantilljuvenil: das origens indo-europeias ao Brasil contemporâneo. São Paulo: Ática, I99I.

. Dicionário crítico de literatura infantil e juvenil brasileira: séculos XIX e XX. 4 ed. São Paulo: EDUSP, I995.

EL FAR, Alessandra. Páginas de sensação: literatura popular e pornográfica no Rio de Janeiro (I870-I924). São Paulo: Companhia das Letras, s.d.

HALLEWELL, Laurence. O livro no Brasil: sua história. São Paulo: T. A. Queirós; EDUSP, 1985.

LAJOLO, Marisa e ZILBERMAN, Regina. Um Brasil para crianças: para conhecer a literatura infantil brasileira: história, histórias, autores e textos. São Paulo: Global, 1986.

. Literatura infantil brasileira: história e histórias. São Paulo: Ática, I994.

LIMA, Herman. História da caricatura no Brasil. Rio de Janeiro: José Olympio, 1963 , v. I.

LÔBO, Yolanda Lima. "Verbete Cecília Benevides de Carvalho Meireles". In FÁVERO, Maria de Lourdes de Albuquerque e BRITTO, Jader de Medeiros (orgs.). Dicionário de educadores no Brasil. 2 ed. Rio de Janeiro: Ed. UFRJ/MEC-Inep-Comped, 2002, pp. 237-47.

MEIRELES, Cecília. Problemas da literatura infantil. 4 ed. Rio de Janeiro: Nova Fronteira, 1984. . Poesia completa. Notícia biográfica. Rio de Janeiro: Nova Aguilar, 1994.

MENEZES, Raimundo de. Dicionário literário brasileiro ilustrado. Sob o patrocínio do INL. Prefácio do Prof. Antonio Candido. São Paulo: Saraiva Livreiro Editores, I969, v. IV.

PIMENTA, Jussara Santos (org.). Leitura, arte e educação: a biblioteca do paviIhão Mourisco (1934-I937). Curitiba: CRV, 201 I. 
72 Literatura, Leitura e Educação

PIMENTEL, Figueiredo. Histórias da avósinha. Rio de Janeiro: Livraria Quaresma Editora, 1936.

SANTOS, Aline Costa. A Comissão Nacional de Literatura Infantil e a formação do público leitor infantojuvenil no Governo Vargas (1936-1938) (dissertação). UFRJ, 201 I.

SENNA, Homero. República das letras, 20 entrevistas com escritores. 2 ed. Rio de Janeiro: Olímpica, 1968.

SILVA, Márcia Cabral da. Uma história da formação do leitor no Brasil. Rio de Janeiro: EdUERJ, 2009. e SANTOS, Aline Costa. "Por que ler literatura infantil? Conceitos e abordagens à luz das contribuições de Cecília Meireles (I930-I95I)". Linha Mestra, ALB, v. I, pp. 3II-I7, 2014. 


\title{
3
}

\section{Literatura manuscrita nas leituras para a infância brasileira (1901-1955)}

\author{
Estela Natalina Mantovani Bertoletti
}

\section{Introduçáo}

O que se oferecia às crianças para leitura na escola brasileira quando esse se tornou um dos principais espaços sociais de educaçáo, na primeira metade do século XX?

Para responder a essa questão, é possível enumerar os textos e autores que circularam na escola a partir da análise dos livros de leitura que foram produzidos e aprovados para uso nesse espaço. Essa enumeração é considerada uma forma de acesso a um instrumento preliminar de pesquisa, que pode subsidiar e fornecer pistas que contribuam para a produção de uma história da leitura e do leitor, levando em conta os sujeitos e os objetos nela envolvidos.

Nesse sentido, buscando contribuir para a produção de pesquisas sobre livros escolares como fonte para a história da leitura e do leitor, o objetivo, aqui, é examinar o que se oferecia às crianças para leitura na escola brasileira, em um livro que circulou formando geraçôes de leitores: o livro de leitura manuscrita ou paleógrafo, Leitura manuscripta: liçôes colligidas, portador de uma literatura manuscrita para leitura na infância, nos limites da escola.

\footnotetext{
I. Este texto foi publicado na revista Teias, v. I6, n. 4I (20I5), e adequado para este livro.
} 
A escolha desse objeto de estudo deveu-se à sua singularidade: um livro impresso, porém em letra manuscrita, para o ensino da leitura de diversas grafias. Essa obra circulou na escola brasileira dentro do movimento de um incipiente mercado editorial, na primeira metade do século XX, concorrendo com outros paleógrafos e com outros livros de leitura impressos em letra bastáo. Além desse, outros foram os motivos:

I. Sua longevidade, tendo em vista que circulou por, pelo menos, 54 anos no mercado editorial brasileiro, com a primeira edição provavelmente em I90I, pela Tipografia Siqueira, ${ }^{2}$ passando, a partir da $9^{a}$ edição, em 1909, para a Livraria Francisco Alves e chegando à última edição em I955 (Razzini, 20I4);

2. O fato de seu circuito de produção e comunicação ter sido, entre os outros paleógrafos em circulação à época, o único totalmente brasileiro, com edição e impressão no país (Batista, 2009), pelas "Officinas Graphicas da Livraria Francisco Alves";

3. Sua inovação em relação aos outros paleógrafos que circulavam na escola brasileira, uma vez que, segundo Batista (2009, pp. $164-5)$,

[... a obra rompe com o modelo de organizaçáo bipartida dos paleógrafos anteriores, por conter apenas a antologia de textos, sem fazer a apresentaçáo prévia das letras do alfabeto em diferentes tipos de escrita. [...] apresenta a coletânea de textos, de diferentes autores, composta tanto de narrativas de fatos históricos ou de biografias (Bartolomeu Bueno da Silva, Bartolomeu Gusmão, os Andradas, a invenção da imprensa, entre outros) quanto de textos - e se trata de uma segunda ruptura promovida pela obra em relação às demais de uma literatura dirigida à leitura da criança na escola (adaptaçôes

2 Segundo Razzini (20I4), a Tipografia Siqueira teve várias denominações, sendo Typographia a vapor Espindola, Siqueira \& Comp. à época da publicação da primeira edição de Leitura $M a$ nuscripta. 
de fábulas, poemas, pequenas narrativas). A ocorrência, ainda, de autores de livros de instrução do final do século XIX entre as personagens biografadas é também um diferencial entre o livro e os demais paleógrafos [...].

Por tais motivos, realizei um exame dos textos e dos autores do livro Leitura manuscripta: liçóes colligidas, de modo a entender o que se dava para ler na escola brasileira na primeira metade do século XX, mediante os protocolos de leitura (Chartier, I990) autorizados que formaram geraçóes de leitores na escola, por mais de meio século.

\section{I Os livros de leitura na história da leitura e do leitor no Brasil}

Sabe-se que, no Brasil, pelo menos até meados do século XIX, raros eram os livros escolares para a infância. À época, circulavam uns poucos livros produzidos e publicados sobretudo na Europa, além de manuscritos, como documentos de cartório, cartas, textos religiosos, ofícios, entre outros, para o ensino da leitura (Pfromm Neto et al., I974). O depoimento de Sílvio Romero³ é elucidativo dessa afirmação:

Ainda alcancei o tempo em que nas aulas de primeiras letras apren-
dia-se a ler em velhos autos, velhas sentenças fornecidas pelos cartó-
rios dos escrivães forenses.
Histórias detestáveis e enfadonhas, em sua impertinente banalida-
de, eram-nos ministradas nesses poeirentos cartapácios. Eram como

3 Sílvio Vasconcelos da Silveira Ramos Romero nasceu em 2I de abril de I85I, em Lagarto/SE, e faleceu em I8 de julho de I9I4, no Rio de Janeiro/RJ. Foi crítico, ensaísta, folclorista, polemista, professor e historiador da literatura brasileira. Em 1897, fundou a cadeira no 17 da Academia Brasileira de Letras (ABL), escolhendo como patrono Hipólito da Costa (Academia, 20I7a, s.p.). 
clavas a nos esmagar o senso estético, embrutecer o raciocínio e estragar o caráter.

Era então precisa uma abundante seiva nativa para resistir a semelhante devastação (Romero apud Zilberman e Lajolo, I988, p. 265).

Do mesmo modo, a narração de João Lourenço Rodrigues, ${ }^{4}$ recuperada por Pfromm Neto et al. (I974), ilustra a questáo:

[...] o professor preparava um $\mathrm{ABC}$ manuscrito, em folha de papel, que se pegava "com pega-mão, para não sujar". Em seguida à carta manuscrita do $\mathrm{ABC}$, "veio o b-a-bá, que servia de início à série bastante longa das cartas das sílabas. Depois destas vieram as cartas de nomes e por último as cartas de fora, que serviam de remate à aprendizagem da leitura. O método adotado era o da soletração. As cartas de fora, cedidas ao professor por empréstimo, serviam para exercitar os alunos nas dificuldades da letra manuscrita (...). Os meninos tinham direito de escolha e davam preferência a certas dessas cartas, de formato maior e conteúdo menor. Eram ofícios dirigidos ao professor e alguns deles traziam a assinatura do Inspetor Geral” (Pfromm Neto et al., 1974, p. 159, grifos dos autores).

Nesse sentido, muitos eram os reclamos de intelectuais e educadores não somente quanto à falta de material especialmente produzido para esse fim, como também à falta de produto brasileiro, seja pelos temas, seja pela feitura de material, seja ainda pelos autores. Emblemático é o posicionamento de José Veríssimos

4 Joāo Lourenço Rodrigues era aluno da escola primária, em I875, segundo Pfromm Neto et. al. (1974).

5 José Veríssimo Dias de Matos nasceu em 8 de abril de 1857, em Óbidos/PA, e faleceu em 2 de fevereiro de 1916, no Rio de Janeiro/ RJ. Foi jornalista, professor, educador, crítico e historiador literário. Fundou a cadeira $\mathrm{n}^{\circ} \mathrm{I} 8 \mathrm{da} \mathrm{ABL}$, tendo sido eleito como patrono João Francisco Lisboa (Academia, 20I7b, s.p.). 
(I896) sobre essa situação, clamando por um livro de leitura para brasileiros.

Cumpre que ele seja brasileiro, não só feito por brasileiros, que não é o mais importante, mas brasileiro pelos assuntos, pelo espírito, pelos autores trasladados, pelos poetas reproduzidos e pelo sentimento nacional que o anime (Veríssimo apud Zilberman e Lajolo, I988, p. 272).

Como é possível observar por esses depoimentos, a natureza dos livros escolares é complexa, não somente por seu conteúdo, mas também por seu próprio formato e finalidade:

[...] os livros didáticos nem sempre são livros, mas apresentam-se em diferentes suportes materiais; o texto didático nem sempre se restringe ao texto explicitamente elaborado e reproduzido tendo em vista um destino escolar; tampouco o texto didático é uniforme na maneira como se articula com o trabalho de ensino e com a formação que pretende auxiliar [...] (Galvão e Batista, 2009, p. 28).

Já no século $\mathrm{XX}$, os materiais didáticos especialmente voltados para a infância brasileira passaram a ser não somente reivindicados, como também produzidos, incentivando o nascimento de um mercado especializado no que se convencionou chamar de livros escolares.

Bastante híbridos, complexos e fluidos em sua gênese, os livros escolares brasileiros oscilavam entre aqueles de caráter mais pedagógico e os outros de caráter mais ficcional e de fantasia, sempre voltados, contudo, à preocupação de levar ensinamento útil de forma agradável, de modo a substituir, paulatinamente, os "detestáveis e enfadonhos" materiais produzidos em outros países ou em 
outras esferas da sociedade, como os manuscritos mencionados, e utilizados na escola para o ensino da tríade: ler, escrever e contar.

Sobre os livros escolares de ficção, concebidos como "literatura infantil”, uma vez que eram produzidos intencionalmente para a criança leitora, Hansen (20II, p. 54), analisando-os em seus aspectos cívico-pedagógicos e nacionais, sobretudo aqueles que apresentam caráter de fantasia, afirma textualmente que, neles, estabelecia-se um campo "[...] de disputa entre diferentes projetos para o futuro da nação brasileira [...]”, uma vez que a criança era idealizada como futuro cidadão "[...] que, ao se tornar objeto de uma ação pedagógica eficaz, transformar-se-ia no principal agente do progresso do país" (Idem, p. 78).

Em relação à importância dos livros escolares no ensino, Soares (I996) assevera:

[...] o livro didático instituiu-se, historicamente, bem antes [do] estabelecimento de programas e currículos mínimos como instrumento para assegurar a aquisição de saberes escolares, isto é, daqueles saberes e competências julgados indispensáveis à inserção das novas geraçôes na sociedade, aqueles saberes que a ninguém é permitido ignorar (p. 55).

Nesse aspecto, entre os livros escolares produzidos, encontram-se cartilhas, livros de leitura, manuais de ensino, livros de literatura infantil, antologias, entre outros. Inicialmente produzidos por um tímido mercado editorial brasileiro, levando-se em conta o escasso público a que se dirigia, ${ }^{6}$ esses livros foram se espe-

6 De acordo com Pfromm Neto et al. (1974, p. I70), “em I836, não ia além de 640 o número de alunos das escolas primárias no município da Corte. De meados do século a I870, o total de alunos matriculados elevou-se de pouco mais de setenta mil para quase cento e noventa mil. Em I886, o país contava com 213.670 alunos matriculados em 6.605 escolas primárias públicas. Em algumas províncias - que, após o Ato Adicional de I834, passaram a legislar sobre 
cializando e sofisticando seus métodos, técnicas e alcance. Desse modo, os livros escolares tornaram-se um material indispensável no processo de escolarização das crianças até os dias atuais.

Nesse contexto, sob diferentes configuraçôes e projetos editoriais, os livros escolares brasileiros representaram diversos modos de se conceber a formação do leitor (Lajolo e Zilberman, I99I), em consonância com as exigências específicas da escola e de formação de e para a infância (Corrêa, 2000). Isso justifica a escolha de textos e autores que os compunham, bem como a estrutura e a forma que apresentavam, obedecendo a um projeto editorial em diálogo com as necessidades e os objetivos educacionais de sua época.

Os livros de leitura manuscrita, ou paleógrafos, destinavam-se ao ensino da leitura, e náo da escrita, e cumpriram uma espécie de transição entre os escassos materiais para ensino da leitura, elaborados pelos próprios professores, e os livros de leitura mais sofisticados e com um padrão estabelecido nas séries de leitura graduada. Nesse sentido, pode-se dizer que conviveram com essas séries, concorrendo e cumprindo objetivo diverso e de grande relevância social à época, no que diz respeito ao ensino da leitura de diferentes caligrafias que circulavam socialmente.

Batista (2005) organizou dados sobre sete paleógrafos que tiveram circulação, pelo menos de meados do século XIX a meados do século XX.

ensino público - cresceu significativamente o movimento em favor da escola elementar, na segunda metade do século passado". 
Quadro 3.I. Paleógrafos ou livros de leitura manuscrita

\begin{tabular}{|c|c|c|c|}
\hline Título & Autor & $\begin{array}{l}\text { I }^{\text {a }} \text { ediçáo } \\
\text { localizada }\end{array}$ & Circulaçáo \\
\hline $\begin{array}{l}\text { Arte de aprender a ler a letra ma- } \\
\text { nuscrita para uso das Escholas em } \\
\text { Io liçóes progressivas do mais fácil a } \\
\text { o mais difícil }\end{array}$ & $\begin{array}{l}\text { Duar- } \\
\text { te Ventura }\end{array}$ & $\begin{array}{l}\text { Provavelmen- } \\
\text { te em I } 840\end{array}$ & até I9OI \\
\hline $\begin{array}{l}\text { O paleographo em escala calligra- } \\
\text { phica para apprender a leitura ma- } \\
\text { nuscripta, approvado pelo Conselho } \\
\text { Superior d'Instrucçâo }\end{array}$ & Carlos Silva & I864 & até I9I2 \\
\hline $\begin{array}{l}\text { O segundo e novo paleographo, em } \\
\text { escala calligraphica: leitura manus- } \\
\text { cripta etc. }\end{array}$ & Carlos Silva & 1869 & $\begin{array}{l}\text { Não } \\
\text { informado }\end{array}$ \\
\hline $\begin{array}{l}\text { Paleographo, ou Arte de aprender } \\
\text { a ler a letra manuscripta, para uso } \\
\text { das escolas da Provincia do Pará }\end{array}$ & $\begin{array}{l}\text { Joaquim Pe- } \\
\text { dro Corrêa } \\
\text { de Freitas }\end{array}$ & I87I & $\mathrm{I} 3^{\mathrm{a}} \mathrm{em} \mathrm{I} 886$ \\
\hline $\begin{array}{l}\text { Curso graduado de letra manuscri- } \\
\text { ta em } 2 \text { I liçóes composto para o uso } \\
\text { da mocidade brasileira }\end{array}$ & $\begin{array}{l}\text { sem indicação } \\
\text { de autoria }\end{array}$ & $\begin{array}{l}\text { segunda } \\
\text { edição em I872 }\end{array}$ & nona em I890 \\
\hline Leitura Manuscripta & $\mathrm{BPR}$ & I9OI & 1955 \\
\hline Exercicio de leitura manuscrita & $\begin{array}{l}\text { Lin- } \\
\text { dolfo Gomes }\end{array}$ & 1926 & 1963 \\
\hline
\end{tabular}

Fonte: Batista, 2005.

Conforme se observa, no Brasil os livros de leitura manuscrita circularam por mais de cem anos e, entre eles, estava Leitura manuscripta. A primeira edição desse livro circulou ao lado de, pelo menos, dois outros paleógrafos: Arte de aprender a ler a letra manuscrita para uso das Escholas em Io liçöes progressivas do mais fácil a o mais dificil, de Duarte Ventura, e $O$ paleographo em escala calligraphica para apprender a leitura manuscripta, approvado pelo Conselho Superior d'Instrucção, de Carlos Silva. Além disso, manteve-se no mercado editorial, concorrendo náo somente com outro, Exercício de leitura manuscrita, de Lindolfo Gomes, como também com uma cultura que foi, aos poucos, colocando em segun- 
do plano a exigência social que provavelmente gerou a necessidade de publicar livros para o ensino da leitura de textos escritos em letra manuscrita: a de leitura de diferentes caligrafias.

Se, durante o século XIX, a leitura de manuscritos era uma urgência devido à grande circulação desse tipo de material em todas as esferas da sociedade, inclusive na escola, os paleógrafos supriam a necessidade de ensino da letra manuscrita, substituindo, de uma forma mais sofisticada, aquele tipo de documento. Em vista disso, a legislaçáo escolar previa o ensino de leitura manuscrita, e o mercado editorial de livros escolares buscou preencher e aproveitar essa fatia no mundo das ediçóes, como já se ressaltou. No século XX, entretanto, a exigência social de leitura manuscrita foi reduzida, de modo crescente, pela circulaçáo cada vez maior de impressos reproduzidos em diferentes técnicas e tipos de letra bastão. A longevidade de Leitura manuscripta é, portanto, um fenômeno digno de análise. ${ }^{7}$

\subsection{O livro Leitura manuscripta: liçóes colligidas}

\subsection{Aspectos editoriais}

O livro Leitura manuscripta: liçóes colligidas ${ }^{8}$ é composto de textos reproduzidos por processo litográfico em diferentes letras, todas verticais, e encadernado em brochura no formato in-I2. ${ }^{9}$ A capa dura contém a única ilustraçâo do livro: um galho sobre

\footnotetext{
7 É curioso notar que poucos são os estudos sobre eles, à exceção de mençôes à sua existência e, mais pontualmente, alguns esboços de sua trajetória e circuito de produção e comunicação (Darnton, 20I0). Em alguns casos, inclusive, há análises descritivas de sua materialidade, como em Batista (2005; 2009), o que aponta para lacunas e necessidades de pesquisa.

8 Năo conseguimos precisar a data de publicação do exemplar analisado, uma vez que não era comum essa informação em seus exemplares. Provavelmente, trata-se de uma ediçáa da década de I930, já que há uma inscrição de uso no verso da capa com a data de 1935 .

9 O formato in-I2 corresponde ao formato francês de I7,5cm x IIcm (Hallewell, 2005).
} 
o qual repousa um pássaro, ocupando toda a margem direita e o alto da folha. Traz também título, subtítulo e autoria indicada apenas pelas iniciais (BPR), todas em letras manuscritas e carimbo com indicação da editora e dos locais (Rio de Janeiro, São Paulo e Belo Horizonte). A quarta capa traz um extrato do catálogo da Livraria Francisco Alves, contendo título e preço de livros escolares, separados por autores. Uma lista dos livros de autoria de Arnaldo de Oliveira Barreto, Romão Puiggari, Thomaz Antonio Galhardo e Ramon Rocca Dordal ${ }^{10}$ antecede a folha de rosto, que reproduz as informaçôes da capa, sem ilustração.

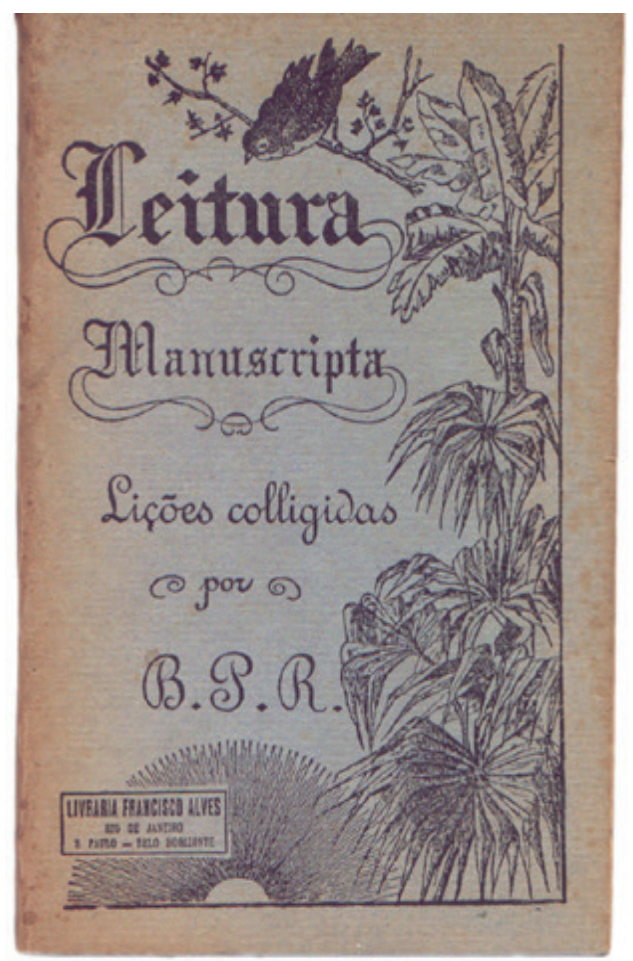

Figura I: Capa do livro Leitura Manuscripta - Liçóes colligidas

Fonte: Acervo particular de L.S.M.

Io Estudos sobre Arnaldo Barreto, Ramon Rocca e Thomaz Galhardo como sujeitos da história do ensino de leitura e escrita no Brasil podem ser vislumbrados, respectivamente, em: Bernardes (2015); Pasquim (2015); e Santos (2015). 
Antes dos textos que se iniciam na página 5 e seguem numerados até a p. I28, tem-se a informação "Approvado e adoptado pelo Governo para as Escolas publicas do Estado", o que significa que o livro não somente foi autorizado, como também foi comprado para ser distribuído às escolas, e que a longevidade de publicação de Leitura Manuscripta representou sua utilizaçáo efetiva para o ensino da leitura, se levarmos em conta que a compra leva à adoção do material.

Ao final de alguns textos, existem quadros pautados contendo ora letras do alfabeto, ora numerais, ora frases curtas, indicando uma possível utilização do livro também para o ensino da escrita, embora não fosse essa a funçâo primeira dos paleógrafos, conforme já assinalado.

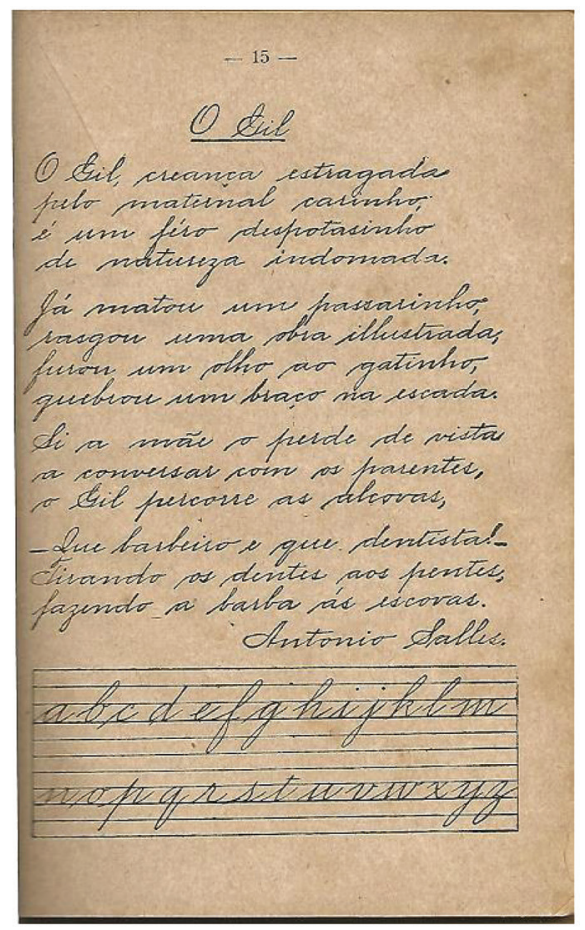

Figura 2: Quadro pautado ao final do texto "O Gil"

Fonte: Acervo particular de L.S.M. 
É curioso notar a autoria do livro indicada apenas pelas iniciais BPR. De acordo com Batista (2009), trata-se de Arnaldo de Oliveira Barreto, Romão Puiggari e Ramon Rocca. Razzini (20I4), contudo, afirma que o B corresponde a Alfredo Bresser. Seja Barreto ou Bresser, importa salientar e questionar por que professores e autores de livros didáticos como os apontados como autores de Leitura manuscripta omitiriam essa informaçáo. Teriam vendido os direitos autorais para a Livraria Francisco Alves? A estratégia de venda de livros a partir do renome do autor não teria sido considerada necessária pelo editor?

Pfromm Neto et al. (1974) ressaltam o desejo de elaborar livros de leitura e outros textos didáticos despertado em autores como os citados, quando surgiram condiçóes favoráveis para o estabelecimento e a ampliaçáo do mercado de livros escolares, a partir do crescimento do número de matrículas de alunos e de escolas primárias no Brasil.

Hallewell (2005), igualmente, destaca o interesse de editores nacionais propiciado pela melhoria da qualidade da educação, a ponto de criar um mercado viável para os livros escolares. Nesse sentido, é possível notar, no livro em questão, características do progresso nas técnicas de edição que sedimentaram paulatinamente os livros escolares no Brasil.

\subsubsection{Os textos}

O livro Leitura manuscripta: liçôes colligidas é organizado em 65 textos, organizados em forma de índice, conforme se vê a seguir.

Quadro 3.2 Textos e autores do livro Leitura manuscripta: liçōes colligidas

\begin{tabular}{ll} 
Título & Autor \\
\hline A Calligraphia & BPR \\
\hline A lingua portuguesa & José Bonifácio \\
\hline
\end{tabular}


Título

\begin{tabular}{|c|c|}
\hline Vozes de animaes & Pedro Diniz \\
\hline Lucas & Castro Alves \\
\hline O Gil & Antonio Salles \\
\hline Natal & Antonio Salles \\
\hline Anniversario & Alvares de Azevedo \\
\hline Arrependimento infantil & Mendes Leal \\
\hline Bosquejo & Raymundo Corrêa \\
\hline A superstição & Felisberto de Carvalho \\
\hline Felisberto de Carvalho & Sem indicação de autoria \\
\hline As duas mães & Bulhão Pato \\
\hline Amor de familia & Camilo Castello Branco \\
\hline A lagarta e o bicho da seda & Feliciano de Castilho \\
\hline Um castello... em papas! (autographo) & Arnaldo de Oliveira Barreto \\
\hline A Palavra & Latino Coelho \\
\hline Antonio Joäo & Escragnolle Taunay \\
\hline Amigos & Guilherme Braga \\
\hline O relógio (autographo) & Arnaldo de Oliveira Barreto \\
\hline Glorias futuras & Hilario Ribeiro \\
\hline Hilario Ribeiro & Sem indicação de autoria \\
\hline O leão e a raposa & Marqueza de Alorna \\
\hline Piratininga & Americo Brasiliense \\
\hline D. Maria de Souza & Manuel de Azevedo \\
\hline Chromo & B. Lopes \\
\hline O mestre de reza & M. A. d'Almeida \\
\hline Bartholomeu Bueno da Silva & Pinheiro Chaga \\
\hline O orgulho da águia & Vicente de Carvalho \\
\hline Astucia do tigre & Fr. Luis de Granado \\
\hline Patria (autographo) & Carlos Gomes Cardim \\
\hline O Sabiá & Fagundes Varella \\
\hline O lobo e o cordeiro & Pe. M. Bernardes \\
\hline A raposa e as uvas & Bocage \\
\hline Salto de Itú & Salvador de Mendonça \\
\hline Eia avante! & Rozendo Monis \\
\hline Opresbyterio & Alexandre Herculano \\
\hline O lobo e o cáo magro & Eduardo Garrido \\
\hline Caçada de bugio & A. Vieira \\
\hline Frei Fulgencio & D. M. Azevedo \\
\hline
\end{tabular}


Título

\begin{tabular}{ll}
\hline Oratinho (autographo) & Ramon Puiggari \\
\hline Rumo do Oriente (autographo) & Amadeu Amaral \\
\hline Um Raio de Sol & Suzanina Cornaz \\
\hline Mäe e Filho (autographo) & J. Pinto e Silva \\
\hline Um estratagema & Joáo Francisco Lisbôa \\
\hline O Padre voador & Sem indicaçáo de autoria \\
\hline Marinha (autographo) & Alberto Souza \\
\hline General Osorio & E. Osorio \\
\hline A primeira escola de S. Paulo & Compilaçóes históricas de R. \\
& Puiggari \\
\hline Um apólogo & Machado de Assis \\
\hline Um quináo & Joáo Borges \\
\hline Meus companheiros & Ramon Puiggari \\
\hline A volta (autographo) & J. Pinto e Silva \\
\hline Jaguarari & Gonçalves Dias \\
\hline Guttenberg e a imprensa & Barão de Macahubas \\
\hline Baräo de Macahubas & Sem indicaçáo de autoria \\
\hline Inteireza dos Andradas & Antonio Menezes Vasconcellos \\
& de Drummond \\
\hline O poeta Silva Alvarenga & Sem indicaçáo de autoria \\
\hline Um anjinho enfermeiro & Menezes Vieira \\
\hline Dr. Menezes Vieira & Sem indicaçáo de autoria \\
\hline A Flôr & A. Feliciano de Castilho \\
\hline O desembargador Petra & Joaquim Manoel de Macedo \\
\hline Joaquim Manoel de Macedo & Sem indicaçáo de autoria \\
\hline Maxima & Marquês de Maricá \\
\hline A cigarra e a formiga & Bocage \\
\hline O Brasil & Sebastião da Rocha Pitta \\
\hline
\end{tabular}

Fonte: Leitura manuscripta: liçōes colligidas.

Como se observa no Quadro 3.2, todos os textos são intitulados e foram produzidos por 52 diferentes autores, sendo que 58 desses textos vêm assinados. ${ }^{\text {II }}$ A grande quantidade de autores em relação ao número de textos justifica-se por se tratar de uma co-

II Apenas em sete textos não há indicação de autoria. 
letânea, como já ressaltado em relação ao subtítulo do livro, uma vez que foi esse o modelo de livro de leitura que prevaleceu no final do século XIX, no Brasil (Soares, 200I), sendo 34 autores brasileiros, I7 portugueses e um espanhol. A presença maciça de autores de nosso país representa uma resposta aos reclamos dos intelectuais daquele tempo, assinalada no início deste artigo.

O primeiro texto, assinado por BPR, trata, em forma de diálogo, da importância da caligrafia, embora nenhum desses autores (Arnaldo Barreto ou Alfredo Bresser, Romão Puiggari e Ramon Rocca) fosse calígrafo. Desse modo, o tema é abordado do ponto de vista da educaçáo, haja vista a atuaçáo desses autores como professores que propunham modos de fazer e de pensar a educaçáo brasileira, atuando, sobretudo, no ensino de leitura e de escrita.

[..] A calligraphia deve ser cuidada com carinho. Uma bonita lettra é um excelente dote no homem. Digo-te mais, é uma prova de boa educação.

- De boa educação, papae?

- Sim. A boa educação, a civilidade, eu a resumo em poucas palavras. Para mim não consiste em certas e determinadas etiquetas, mas num principio que as resume todas e que a todas deve servir de base. Este principio é o seguinte:

Em nossas relaçóes, tanto familiares como sociaes, devemos procurar sempre aquillo que fôr agradável ás pessoas com quem tratamos e evitar tudo aquillo que possa ser desagradável (BPR, s.d., pp. 6-7).

Ainda assim, são de próprio punho os textos de autoria de Arnaldo de Oliveira Barreto e Romáo Puiggari, bem como outros cinco deles, que foram reproduzidos no livro pelos próprios autores, na qualidade de autógrafos, como se verifica também no Qua- 
dro 3.I: Carlos Gomes Cardim, Amadeu Amaral, Alberto Sousa e J. Pinto e Silva. É importante ressaltar que os dois últimos são autores de textos que foram produzidos antes de 1900.

Além desses, a maioria dos autores é contemporânea à publicação do livro, sendo considerados clássicos, à época, somente sete deles, como Antonio Ferreira de Castilho, Bocage, Fr. Luís de Granada, Marquês de Maricá, Pe. Antonio Vieira, Pe. Manuel Bernardes e Rocha Pitta. Sobre a presença de autores antigos nos livros de leitura e a necessidade de haver autores brasileiros e "modernos", a crítica de José Veríssimo (I896) é, mais uma vez, significativa:

Os nossos livros de excertos é aos autores portugueses que os vão buscar, e a autores cuja clássica e hoje quase obsoleta linguagem o nosso mal amanhado preparatoriano de português mal percebe. São os Fr. Luís de Sousas, os Lucenas, os Bernardes, os Fernão Mendes e todo o classicismo português que lemos nas nossas classes da língua, que aliás começa a tomar nos programas o nome de língua nacional. Pois, se pretende, ao meu ver erradamente, começar o estudo da língua pelos clássicos, autores brasileiros, tratando as coisas brasileiras, não poderiam fornecer relevantes passagens? E Santa Rita Durão, e Caldas, e Basílio da Gama, e os poetas da gloriosa escola mineira, e entre os modernos João Lisboa, Gonçalves Dias, Sotero dos Reis, Machado de Assis e Franklin Távora, e ainda outros, não têm páginas que, sem serem clássicos, resistiriam à crítica do mais meticuloso purista? (Veríssimo apud Zilberman e Lajolo, I988, pp. 27I-2).

Como se vê, Leitura manuscripta corresponde aos anseios do crítico, com 45 autores entâo modernos tendo seus textos reproduzidos nessa obra: professores e escritores, sendo muitos deles poetas, romancistas, jornalistas, juristas, diplomatas, polí- 
ticos, entre outras profissóes, todos voltados a uma produção escrita para adultos. Desse modo, à exceção dos autores professores que escreviam livros didáticos voltados à infância - Arnaldo de Oliveira Barreto, Antonio Gomes Cardim, Barão de Macaúbas, Hilário Ribeiro, Romão Puiggari e Ramon Rocca Dordal - e que têm textos reproduzidos em Leitura manuscripta, os outros não têm em vista a especificidade da infância, mas são autores renomados, sobretudo representantes dos movimentos literários em voga e atuantes em diversas esferas da sociedade brasileira, como intelectuais, entre os quais, destacam-se: Álvares de Azevedo, Castro Alves, Escragnole Taunay, José Bonifácio, Gonçalves Dias, Fagundes Varela, Machado de Assis, Manuel Antonio de Almeida, Pedro Dinis, Raimundo Corrêa e Vicente de Carvalho.

É importante ressaltar que, no início do século XX, quando veio a lume a primeira edição de Leitura manuscripta, a produçáo literária para crianças era, em geral, composta por traduçôes e adaptaçóes (Lajolo e Zilberman, I99I), não havendo um número muito expressivo de autores que se ocupassem de escrever diretamente para a criança. Isso parece justificar a presença de autores voltados ao público adulto nas páginas do livro. E foi na relação com a escola e o ensino de leitura e escrita que a literatura infantil brasileira começou a tomar corpo e pôde, gradativamente, tornar-se um gênero autônomo. ${ }^{\text {I2 }}$ Assim, a partir da compreensão da infância como parte diferenciada da vida humana e do valor formativo do livro e da leitura, os autores passaram a se ocupar da especificidade da produção escrita diretamente para a criança.

\footnotetext{
I2 A constituição da literatura infantil brasileira não se deu sem impasses ou problemas. Diversos estudos que traçam um histórico do gênero apontam para as relaçôes entre literatura e ensino como um problema de origem. Nessa direçâo, ver Lajolo (1982); Lajolo e Zilberman (I99I); Zilberman e Lajolo (1988).
} 
Ainda sobre os autores, é necessário questionar por que, à exceção de Suzanina Cornaz e da marqueza de Alorna, todos eram homens, cabendo reflexôes tanto sobre o lugar e o papel das mulheres no cenário literário e social como o das meninas na instituição escolar.

Quanto aos textos compilados, podem ser divididos em duas categorias: uma que corresponde a textos de caráter mais informativo e outra de caráter mais ficcional. No entanto, a maioria apresenta inflexóes entre uma e outra categorias, havendo apenas prevalência de uma natureza sobre a outra. Em uma tentativa de categorização, os textos informativos foram quantificados no quadro a seguir.

Quadro 3.3 Textos com caráter informativo no livro Leitura manuscripta: liçóes colligidas

Tipos de texto

Quantidade

\begin{tabular}{lc}
\hline Diálogos & 2 \\
\hline Biografias & 7 \\
\hline Narração & 7 \\
\hline Descrição & IO \\
\hline Máximas & 2 \\
\hline Total & $\mathbf{2 8}$ \\
\hline
\end{tabular}

Fonte: Informaçôes retiradas de Leitura manuscripta: lições colligidas e organizadas pela autora.

Os ficcionais, por sua vez, estão relacionados no quadro a seguir.

Quadro 3.4. Textos com caráter ficcional no livro Leitura manuscripta: liçōes colligidas

Tipos de texto

Quantidade

\begin{tabular}{ll}
\hline Poemas & I6 \\
\hline Carta & I \\
\hline Narração & 8 \\
\hline
\end{tabular}


Tipos de texto

Quantidade

\begin{tabular}{ll}
\hline Descrição poética & 3 \\
\hline Trecho de romance & I \\
\hline Fábulas adaptadas & 2 \\
\hline Fábulas em verso & 2 \\
\hline Fábulas em versos parafraseadas & I \\
\hline Narrativa épica & I \\
\hline Apólogo & 2 \\
\hline Total & 37 \\
\hline
\end{tabular}

Fonte: Informaçôes extraídas de Leitura manuscripta: liçôes colligidas e organizadas pela autora.

Observa-se, nos Quadros 3 e 4, que, em alguns casos, os mesmos tipos de textos oscilam entre uma categoria e outra, apenas prevalecendo a natureza, em uma espécie de hibridismo. Esse aspecto remete à característica fluida das origens de uma literatura especialmente voltada a crianças no Brasil, qual seja, a de proporcionar ensinamento útil por um meio agradável. Assim, informação e ficção permeiam os textos dirigidos ou adaptados para crianças, uma vez que grande parte deles - em especial no livro em análise - foi escrita e publicada para circular no âmbito escolar, conforme já apontado em relação à origem do gênero denominado literatura infantil e à sua estreita ligação com a escola.

Arroyo (1968) foi o primeiro estudioso a admitir essa vinculação histórica não como a causa dos males da literatura infantil, mas como constitutiva dela. ${ }^{13}$ Já Zilberman e Lajolo (1988) indicam que esse modo de conceber a literatura infantil associou-a aos problemas da escola. Seja um ponto de vista, seja outro, o importante é compreender que, desde os fins do século XIX, a literatura infantil brasileira apresentou os seguintes aspectos: foi produzida e criticada sobretudo por professores ou intelectuais engajados em projetos educacionais; associou o aspecto estético à formação

13. O estudo da contribuição de Leonardo Arroyo para a literatura infantil brasileira pode ser consultado em Assis (2016). 
de valores para as crianças, concebendo-as como seres a "vir a ser"; e submeteu-se ao processo de escolarização de aprendizagem da leitura e da escrita, ou seja, esteve vinculada à instituição escolar.

Além do aspecto híbrido, é notória a diversidade textual que compóe o livro Leitura manuscripta. Notam-se, no Quadro 3.3, cinco diferentes tipos de textos informativos e, no Quadro 3.4, dez diferentes tipos de textos de ficção.

Nesse contexto, compreende-se que o ensino da leitura manuscrita correspondia também a uma gama de textos com diferentes fins e que, por essa razão, pressupunham a aprendizagem de diferentes leituras, diferença que não se circunscreve apenas à diversidade das letras. Como já ressaltado, a presença de textos oriundos da literatura é uma grande novidade, caracterizando uma literatura manuscrita nas leituras para a infância brasileira, o que diferencia esse livro de outros paleógrafos, embora também se encontrem narrativas de fatos históricos, biografias, descriçóes objetivas, entre outros.

Desse modo, não se pode categorizar Leitura manuscripta como integrante do gênero literatura infantil, mas é possível, pelo esforço de ficcionalização da leitura voltada a crianças, levando-se em conta a prevalência de textos com essa natureza (28 informativos e 37 de ficção), conceber esse livro de leitura como representativo também da leitura recreativa, e não somente da leitura com caráter pedagógico, como, à primeira vista, pode-se compreender um livro de leitura. Tanto é assim que os 37 textos de ficção correspondem a gêneros cuja função estética ocupa o primeiro plano. Portanto, esses textos presentes em um livro de leitura escolar correspondem também ao que se considerava leitura auxiliar, cujo cerne consistia em emocionar, predominantemente, e não somente servir como leitura de classe, destinada ao ensino de conteúdo escolar, como se observa no texto "As duas mães", de Bulhão Pato (s.d, p. 30). 
Numa igreja se encontraram

Duas mães em certo dia,

Uma entrava: nesse instante,

Toda cheia de alegria.

Orgulhosa e triunfante,

Levava chegado ao peito,

Um filhinho a baptizar.

Outra, a infeliz que sabia,

Levava um filho também,

Oh! Mas essa pobre mãe

Levava o filho a enterrar!

Cruzaram-se a poucos passos

A que trazia nos braços

Cheio de vida e conforto,

O filho dos seus encantos,

E a triste lavada em prantos,

Que seguia o filho morto.

Trocaram ambas o olhar,

Nisso a mãe afortunada

Foi que rompeu a chorar,

Enquanto a desventurada,

Que o filho tinha perdido,

Oh! maravilhas do amor!

No meio da sua dor

Sorriu ao recém-nascido!

Dada a natureza dos textos que compóem esse livro de leitura, é possível afirmar que houve um esforço de levar a leitura pedagógica e recreativa para o ensino da leitura manuscrita, prevalecendo 
um caráter muito mais de formação de valores morais e pedagógicos do que de conteúdo escolar. Por essa razão, a ideia de levar ensinamento útil de modo agradável prevaleceu nos protocolos de leitura do texto, seja de seus autores, seja de seus editores, com a presença da literatura em letra manuscrita. É importante lembrar que, à época de circulação desse livro, muitas eram as obras de leitura que se voltavam para a tônica de ensinar conteúdo por meio dos livros escolares destinados ao ensino da leitura. Leitura manuscripta, ao contrário desse modelo, fundava-se em um projeto de formação da criança não por meio de conteúdo escolar, mas de propagação de valores emocionais, morais e patrióticos, subsumidos nos textos que o compunham, dado seu caráter ficcional, exercendo, pois, função ao mesmo tempo educativa e formativa.

\section{Consideraçóes finais}

Neste estudo, buscamos examinar os textos e autores presentes no livro Leitura manuscripta: liçóes colligidas a partir da percepção de que os livros de leitura podem ser considerados uma fonte profícua para a história da leitura e do leitor. Logo, essa análise revelou características que permitem compreender o que se oferecia às crianças para a leitura na escola brasileira na primeira metade do século XX:

I. Os autores eram modernos e renomados, sendo, em sua maioria, brasileiros, homens e contemporâneos à publicação do livro Leitura manuscripta, o que resultava em textos atuais, de qualidade e prestígio para a época;

2. A natureza híbrida dos textos, oscilando entre textos informativos e de ficção, imprimia diversidade textual ao livro, mas, sobretudo, denotava preocupação com a formação de uma leitura escolar também conformada pela leitura auxiliar;

3. A função dos textos era, portanto, tanto pedagógica como de recreação, porém, no primeiro caso, não era o conteúdo escolar 
o objetivo do livro, mas os valores emocionais, morais e patrióticos, o que se garantia também com os textos de ficção.

Assim, conclui-se que Leitura manuscripta: liçôes colligidas traz um projeto de formação da infância brasileira em situação escolar, rompendo com o suporte dos materiais de leitura e, ao mesmo tempo, propondo um modo de ler que formou gerações de leitores na escola brasileira, por mais de meio século.

Esse modelo de formação não era exclusivo do livro em análise, porém o exame de seus textos aponta para singularidades que caracterizaram o que se entendeu por muito tempo como um (bom) livro de leitura (manuscrita).

Nesse sentido, estudar livros de leitura pode ser um caminho para a compreensão do que se oferecia às crianças brasileiras como leitura na escola, ou seja, o que se projetava para sua formaçáo.

\section{Referências}

ACADEMIA. “Sílvio Romero”. Disponível em: http://www.academia.org.br/ academicos/silvio-romero/biografia.

. "José Veríssimo". Disponível em: http://www.academia.org.br/academicos/jose-verissimo/biografia.

ARROYO, Leonardo. Literatura infantil brasileira: ensaio de preliminares para sua história e suas fontes. São Paulo: Melhoramentos, 1968.

ASSIS, Vivianny Bessão. A contribuição de Leonardo Arroyo (1918-1985) para a história da literatura infantil brasileira (tese). Universidade Estadual Paulista, 2016.

BATISTA, Antônio Augusto Gomes. "Papéis velhos, manuscritos impressos: paleógrafos ou livros de leitura”. In ABREU, Márcia e SHCAPOCHNIK, Nelson (orgs.). Cultura letrada no Brasil: objetos e práticas. Campinas: Mercado de Letras/Associação de Leitura no Brasil; São Paulo: Fapesp, 2005, pp. 87-II6. 
. "Dos papéis velhos aos manuscritos impressos: paleógrafos ou livros de leitura manuscrita”. In BATISTA, Antônio Augusto Gomes e GALVÃO, Ana Maria de Oliveira. Livros escolares de leitura no Brasil: elementos para uma história. Campinas: Mercado de Letras, 2009, pp. I53-78.

BERNARDES, Vanessa Cuba. "Arnaldo de Oliveira Barreto (I869-I925): atuação e produção para o ensino da leitura”. In MORTATTI, Maria do Rosário Longo et al. (orgs.). Sujeitos da história do ensino de leitura e escrita no Brasil. São Paulo: Unesp, 2015, pp. 93-102.

BPR. Leitura manuscripta: liçóes colligidas. Rio de Janeiro: Livraria Francisco Alves, s.d.

CHARTIER, Roger. A história cultural: entre práticas e representaçôes. Trad. Maria Manuela Galhardo. Lisboa: Difel; Rio de Janeiro: Bertrand Brasil, I990. CORRÊA, Rosa Lydia Teixeira. "O livro escolar como fonte de pesquisa em história da educação". Caderno Cedes, Campinas, n. 52, pp. II-24, nov. 2000.

DARNTON, Robert. O beijo de Lamourette: midia, cultura e revolução. São Paulo: Companhia das Letras, 2010.

HALLEWELL, Laurence. O livro no Brasil: sua história. 2 ed. São Paulo: EDUSP, 2005 .

HANSEN, Patrícia. “Autores, editores, leitores. O que os livros cívicos para crianças da Primeira República dizem sobre eles?”. História, São Paulo, v. 30, n. 2, pp. 5I-80, ago./dez. $201 \mathrm{I}$.

LAJOLO, Marisa. Usos e abusos da literatura na escola: Bilac e a literatura escolar na República Velha. Rio de Janeiro: Globo, 1982.

e ZILBERMAN, Regina. Literatura infantil brasileira: história e histórias. 5 ed. São Paulo: Ática, I99I.

PASQUIM, Franciele Ruiz. "Ramon Roca Dordal (I854-I938) e Carlos Alberto Gomes Cardim (I875-1938)”. In MORTATTI, Maria do Rosário Longo et al. (orgs.). Sujeitos da história do ensino de leitura e escrita no Brasil. São Paulo: Unesp, 2015, pp. 77-92.

PATO, Bulhão. "As duas mães”. In BPR. Leitura manuscripta: liçóes colligidas. Rio de Janeiro: Livraria Francisco Alves, s.d. p. 30. 
PFROMM NETO, Samuel et al. O livro na educação. Rio de Janeiro: Primor/ INL, 1974 .

RAZZINI, Márcia de Paula Gregório. "O poder dos livros de leitura no início do século XX". In MORTATTI, Maria do Rosário Longo e FRADE, Isabel Cristina Alves da Silva (orgs.). História do ensino de leitura e escrita: métodos e material didático. São Paulo: Unesp; Marília: Oficina Universitária, 20I4, pp. 29I-3I3.

ROMERO, Sílvio. "O professor Carlos Jansen e as leituras das classes primárias”. In ZILBERMAN, Regina e LAJOLO, Marisa. Um Brasil para crianças: para conhecer a literatura infantil brasileira. 2 ed. São Paulo: Global, 1988.

SANTOS, Luana Grazielle dos. "Cartilha da infancia, de Thomaz Galhardo". In MORTATTI, Maria do Rosário Longo et al. (orgs.). Sujeitos da história do ensino de leitura e escrita no Brasil. São Paulo: Unesp, 2015, pp. 23-33.

SOARES, Magda. "Um olhar sobre o livro didático". Presença Pedagógica. Belo Horizonte, v. 2, n. I2, pp. 53-63, nov./dez. 1996.

. "O livro didático como fonte para a história da leitura e da formação do professor-leitor”. In MARINHO, Marildes (org.). Ler e navegar: espaços e percursos da leitura. Campinas: Mercado de Letras; Belo Horizonte: Ceale, 200I. (Coleção Leituras no Brasil.)

VERÍSSIMO, José. "A educação nacional”. In ZILBERMAN, Regina e LAJOLO, Marisa. Um Brasil para crianças: para conhecer a literatura infantil brasileira. 2 ed. São Paulo: Global, 1988. 


\title{
4 \\ OTico-Tico: espaço de entretenimento e representação da prática escolar republicana ${ }^{1}$
}

\author{
Aline Santos Costa \\ Cíntia Borges de Almeida
}

Os estudos mais recentes no campo de História da Educação apresentam como proposta uma revisão dos trabalhos que focavam na institucionalização escolar, marcada, principalmente, a partir de meados do século XIX, como o "único" espaço educativo e de representação das práticas pedagógicas. No Brasil, principalmente no período citado, é que se inicia a construção de uma configuração histórica particular em termos de processo de institucionalização da escola primária, considerando "um espaço físico-arquitetônico e as temporalidades múltiplas nela vivenciadas" (Faria Filho e Vidal, 2000, p. 2I). A forma escolar de socialização foi importante e significativa no processo de organização da estrutura e da sociedade brasileira, mas, concomitantemente a ela, outros espaços educativos se expressaram e contribuíram para a organização social citada.

Entre eles, destacam-se os impressos: livros, jornais e revistas que atenderam a públicos diferenciados e ainda disseminaram o ideal civilizatório e de formação nacional. Tomados pelo discurso pedagógico, seus interlocutores agiram, direta e indiretamente, de acordo com as demandas educacionais. A escola passa a ocupar um espaço importante e de relação com outros espaços sociais.

I Este texto foi publicado na revista Teias, v. I6, n. 4I, 20I5, e atualizado para este livro. 
Dessa feita, a forma escolar, conforme apontam Vincent, Lahire e Thin (1994), pode ser compreendida como uma configuração sócio-histórica particular associada a uma reorganização do campo político e religioso, à instauração de uma ordem urbana, que exigia o estabelecimento de novas formas de relaçáo social entre sujeitos de diferentes grupos sociais, bem como à aprendizagem de formas de exercício do poder. Nessa direção, ainda que se propusessem a outros objetivos, os impressos também recorriam a práticas e formas escolares para cumprir um ideal civilizatório. O Tico-Tico não se abstém desse compromisso.

Com a missão de "divertir, estimular e ser útil às petizadas do Brasil", o "jornal das crianças" de I7 de janeiro de 1906 preenchia suas páginas com uma "explicação pessoal" sobre a ausência da historinha envolvendo seu personagem Chiquinho no exemplar da semana anterior. Em resposta a seus inúmeros leitores que lhe escreveram pedindo esclarecimento pela falha, a redação se retratou através de uma "deliciosa" história do personagem:

Chiquinho - Ora mamãe, então logo hoje eu não saio?

Mamãe - Não. Você está tão levado da breca que até pode ser um mau exemplo aos leitores d'O Tico-Tico. No número passado você chegou a esborrachar a cara do copeiro. Hoje fica em casa de castigo [...] (O Tico-Tico, I7/I/1906, p. 5).

A interferência do leitor, a retratação do autor, bem como a participação dos personagens na vida das crianças e vice-versa, tudo isso nos mostra uma nova configuração da imprensa. Náo analisaremos a imprensa entendendo-a apenas como aliada do governo ou cumprindo uma função estritamente política, da forma como funcionava em meados do século XIX.

Por esse novo viés, compreendemos a imprensa a partir de sua evolução proposta pelo período republicano, de modo que deixe 
de ser "o órgão official, funcção homogênea" e opere com "o desenvolvimento da imprensa particular", cristalizando "o seu feitio typico de variedade de gênero". Nesse sentido, analisaremos a imprensa "moderna" com seus "potentíssimos apparelhos orgânicos de informação quotidiana, omnipresente e cabal", destinada a criar relaçóes com seus leitores, "noticiária, commercial, litterária, crítica, aberta aos annuncios, folhetins, poesias" (Bello, I908, p. I5I).

Destaca-se também o objetivo de pesquisar O Tico-Tico sob seu cunho social, refletindo acerca do discurso em torno da "diversão e do encantamento de seus leitores", ainda que as escritas das notícias, ao contrário do lema afirmado, permitam-nos depreender uma preocupação civilizatória em suas páginas.

A revista $O$ Tico-Tico configura-se como um instrumento para se pensarem a expansão da imprensa, a modernização dos meios de comunicação e as estratégias para se divulgarem ideias, pensamentos e projetos de sociedade, mais do que "simplesmente noticiar um desejo oficial". Sem, necessariamente, subordinar-se aos interesses do governo, a redação e a administração dos jornais do início republicano expandiam seus interesses e cumpriam variadas funçóes, formando um "jornal moderno e mais aprimorado" (Idem, I908, p. I5I).

Ainda em meados do século XIX, com a crescente valorização da cultura impressa, os periódicos passam a desempenhar papel significativo na formaçáo de leitores brasileiros. Assim como os livros alcançam lugar privilegiado e preferência nos círculos letrados, o jornal e as revistas despertam a atenção de diversas camadas sociais, por meio de suas narrativas plurais, mais sintetizadas, o que possibilitava uma leitura de modo "extensivo", por meio da qual o leitor lê mais textos e consegue atingir um maior número de informaçóes em menor espaço de tempo. 
A popularização da palavra impressa foi ampliada, apesar dos elevados índices de analfabetismo. ${ }^{2}$ Ao contrário disso, é possível observar diferentes veículos impressos desempenhando papel alfabetizador. Não se trata de processos de alfabetização que substituam o lugar da escola, mas cumprindo um papel, ainda que informal, no processo educacional da sociedade. Com O Tico-Tico, não é diferente.

\section{I Formar para o indivíduo ou para a sociedade?}

A primeira edição d'O Tico-Tico disponível na Fundação Biblioteca Nacional data de 22 de novembro de $1905 .{ }^{3}$ A partir dela, analisamos as intençóes dos editores e autores das notícias do impresso e refletimos sobre as representaçóes feitas pelos leitores a partir das correspondências enviadas à publicação, seja em forma de pedidos, seja em forma de agradecimentos, poemas, participação em concursos, entre outros instrumentos que nos permitem compreender suas leituras.

$\mathrm{Na}$ edição I, encontramos alguns indícios que nos apontam para seus fundadores, para sua materialidade, levando-nos também aos seus objetivos revelados: "divertir, estimular e ser útil às petizadas". No cabeçalho da revista, temos, de antemáo, seu público-alvo: "jornal das crianças", bem como a data de distribui-

2 De acordo com Manoel Bonfim, em discurso pronunciado para as professoras da Escola Normal em 1902, 90\% da população brasileira era composta por analfabetos (Escola Normal, 1904, pp. 59-60). Esses dados alarmantes podem ser observados no jornal mineiro, ao alertar para o fato de que "a instrucção, quase na totalidade de seus estados, póde se dizer: é nulla" (Correio de Minas, 8/II/I906, p. I). Tâo grave quanto o panorama da instruçấo brasileira, consistia a situação do Distrito Federal. Em in de maio de 1915, o jornal $O$ Imparcial afirmava, em uma de suas matérias, que "a capital, em I913, com uma população em torno de I.200.000 habitantes e 63.997 alunos de ambos os sexos, tinha uma população escolar equivalente a $5 \%$ ” ( $O$ Imparcial, II $/ 5 / 1915, \mathrm{p} .3$ ).

3 A data de criação da revista $O$ Tico-Tico encontra-se divulgada no Cinquentenário de O Tico-Tico, retrospecto da vida de O Tico-Tico, da sua fundação até os nossos dias. Noticiário e homenagens diversas a tradicional publicação. Rio de Janeiro: Sociedade Anonyma O Malho, 1956. 
ção semanal (quartas-feiras). No rodapé, vemos o jornal $O$ Malho como responsável por sua redação e administração, além da informação do número de tiragem ( 27 mil exemplares semanais) e o valor de venda do número avulso (200\$ réis).

Esses pontos permitem levantarmos indícios da circulação da revista e de seu alcance. Quem seria seu público-alvo? "Um jornal feito para crianças", mas comprado por adultos, leva-nos a refletir sobre seu objetivo. Como os pais avaliariam o conteúdo da revista se não o lessem a priori? E o que podemos inferir a partir de sua associação com $O$ Malho?

Tais questionamentos nos levam aos objetivos de diversão, encantamento e serviço de utilidade ao leitor. Em notícia publicada no $O$ Tico-Tico de novembro de 1905 , seus redatores reforçam a informação da participação da empresa d'O Malho na publicação do jornal para crianças, endossando a colaboração de escritores e artistas de "nomeada" em sua execução (O Tico-Tico, 22/II/1905, p. 3). ${ }^{4}$ A fim de "instruir e deliciar as crianças", os redatores enfatizam que os marmanjos já possuem seus jornais, sendo este "exclusivamente para os pequeninos, os innocentes, os simples" (Idem, p. 3). No entanto, quem se preocupa com a participação de sujeitos de prestígio e "nomeada"? Uma criança estaria interessada na assinatura de um autor? Acreditamos que tais preocupaçóes provêm de seus responsáveis, que, ao comprarem a revista, estão interessados em oferecer uma formação satisfatória a seus filhos. Trata-se, pois, de discursos endereçados aos pais, aos adultos.

4 Luiz Bartolomeu de Souza e Silva, proprietário de $O$ Malho, recebeu a ajuda de alguns intelectuais na concepçấo de O Tico-Tico: Manoel Bonfim, Renato de Castro e Cardoso Jr. estiveram ao seu lado na criação do periódico que se tornaria referência na imprensa brasileira. Além deles, "um grande número de cartunistas já conhecidos pelo trabalho em $O$ Malho e em outras revistas ilustradas da época - Ângelo Agostini, J. Carlos, Leônidas, Kalixto - participaram ativamente de O Tico-Tico" (Gonçalves, 20II, p. I5). 
Mas como seria essa formação? Podemos pensar em boa e má-formação a partir de quais elementos? Em termos de leitura, a "boa” leitura dizia respeito ao conteúdo adequado especificamente aos interesses de uma sociedade - uma preocupação com a formação da nação civilizada, ordeira, moderna e escolarizada -, que se estendia para além do indivíduo.

Em seu programa, O Malho se propunha, como o próprio nome indica, a "destruir a praxe". "Tudo que passar a seu alcance será a bigorna" ( $O$ Malho, 20/9/1902, p. 4). Em prol de cumprir com "um bem social", o jornal "concorria efficazmente para o melhoramento da raça humana [...]. Pondo em contribuição ao desenvolvimento do riso, temos prestado ao homem serviço" (Idem, p. 4), oferecendo informação com audácia, alegria, mordacidade e irreverência, ainda que seja "às custas de todos" (O Malho, 20/9/1902, p. 4). A educação foi uma das pautas debatidas no jornal, 5 ainda que as notícias/os artigos viessem em forma de crítica ou em solicitação por seu cumprimento.

Entretanto, a transformação social esbarrava nos interesses particulares, nos diferentes posicionamentos expostos no periódico. A educação e a frequência obrigatória, por exemplo, já defendidas pelos articulistas do jornal $O$ Malho, foram atacadas por um governante municipal. Os redatores utilizavam o espaço do periódico para criticar a opiniáo e reforçar seus posicionamentos acerca da importância da instruçáo escolar. De acordo com o jornal, o deputado Ferreira Braga ${ }^{6}$ apresentou à Câmara um projeto de lei que condenava o ensino obrigatório com a seguinte justificativa:

\footnotetext{
5 Ver as notícias: 20/9/1902, pp. 3-4; 3/1/1903, p. 4; 24/1/1903, p. 9; 12/5/1906, p. 4; 16/6/1906, p. I2; entre outras.

6 Professor de Matemática da Escola Militar e da Escola Politécnica na última década do século XIX e no início do XX. Iniciou na política como deputado federal de São Paulo entre 1903-5, pela legenda do Partido Republicano Paulista. Disponível em: http://cpdoc.fgv.br/sites/default/ files/verbetes/primeira-republica/BRAGA,\%20Francisco\%2oFerreira.pdf. Acesso em: I jun. 2017.
} 
Gallileu estudou na frequência obrigatória? Não.

Keppler teve frequência obrigatória? Não.

Pythagoras submetteu-se à frequência obrigatória?Não.

Linneu, Laplace, Aristoteles, Raunier, Coulon, Douvzy, Torre Eiffel, Simonetti e outros sábios estudaram com frequência obrigatória? Não.

Logo, a frequência obrigatória é uma inútil e espalhafatosa pachouchada (O Malho, 29/11/1903, p. 9).

Em resposta à intervenção do deputado para o descumprimento do ensino obrigatório, os articulistas rebateram o pensamento do político: "Muitos deputados, à parte: — o nobre deputado, um sábio também, também não teve frequência obrigatória. Looooooogo... batatas" (Idem, p. 9).

Os artigos trazidos à tona sugerem interesses diversos por parte dos redatores e colaboradores d' O Malho, notadamente o de levantar a bandeira educacional e utilizar as páginas do periódico como um espaço legitimador do discurso que se intentava disseminar. Partindo desse pressuposto, encontramos pistas que nos levam a considerar também a revista $O$ Tico-Tico um instrumento de divulgação dessa formação "adequada” que se esperava da sociedade republicana, com vistas à modernidade.

Uma sociedade que vislumbrava o progresso náo aceitaria, em seu seio, traços de "ignorância" que a reportariam a um passado não muito remoto, considerado atrasado, pouco evoluído, chamado por alguns historiadores de "trevas". ${ }^{7}$ Oferecer a instrução para a população seria, então, o mesmo que levar luzes às trevas.

7 O livro Educação, poder e sociedade no Império brasileiro ajuda-nos a problematizar a disputa dos projetos políticos educacionais pensados, ainda no período imperial, bem como a tensão envolvida nas práticas educativas do início da República, tentando "sufocar" ou apagar as experiências do século XIX (Gondra e Schueler, 2008). Sobre a memória republicana construída, ou melhor, forjada a partir do silenciamento das iniciativas do século XIX, as autoras Alessandra Schueler e Ana Ma- 
O processo de escolarização e de formação social fazia parte do projeto de modernização pensado por vários intelectuais nas primeiras décadas republicanas. Com a criação da revista $O$ Tico-Tico, abria-se mais uma possibilidade de disseminação das ideias desses agentes sociais que atuavam na imprensa. Veja-se o conto "Nina", à guisa de esclarecimento:

Nina dispuzera-se a ensinar a ler ao seu Petit [...].

A um canto da sala de jantar installara a escola, pondo o Petit sobre uma cadeira de braços e deante delle uma carta de a, b, c, a mesma em que ella própria, iniciava os seus estudos.

A mamãe, ao princípio, quis demover a menina do seu intuito.

Que? Nina, uma moça educada, da sociedade, podia lá ter um cão estúpido? Havia de educa-lo também, de ensina-lo, de dar-lhe o maior preparo scientifico litterario possível.

E poz-se à obra [...] Docilmente, Petit ia-se sujeitando ás imposiçôes da menina, suportando as suas impertinências [...]

Houve um momento em que Nina teve de deixar o discípulo sozinho na aula. Ao voltar, encontrou-o sentado noutra cadeira [...]. A menina ia zangar-se, mas teve uma ideia que a comoveu. Pensou que o pobrezinho estava, talvez, fazendo algumas reflexôes. Exclamou:

Coitado! Também eu me nego, quando penso que tenho de aprender tudo aquilo, fico triste às vezes... mas depois me animo e alegro pensando na importância que a instrucção dá a gente! ( $O T i$ co-Tico, II/4/1906, p. 3).

A historinha publicada em O Tico-Tico permite inferirmos algumas representaçóes possíveis a partir de seu texto. Nina, a aluna educada e da sociedade, transmite-nos a ideia do valor moral e

galdi (2009) reafirmam a necessidade de se reverem as produçôes no campo da História e da História da Educação, que, supostamente, "inauguram" a República como marco zero e subjugam o Império, a ideia e a representação de atraso, de precariedade, de "trevas" (p. 37). 
da conduta que se queria construir entre as crianças. $O$ destaque para a necessidade de "um maior preparo scientifico litterario" leva-nos a refletir acerca do papel da educação na sociedade. Observe as imagens que seguem a história de Nina e seu cachorro Petit:

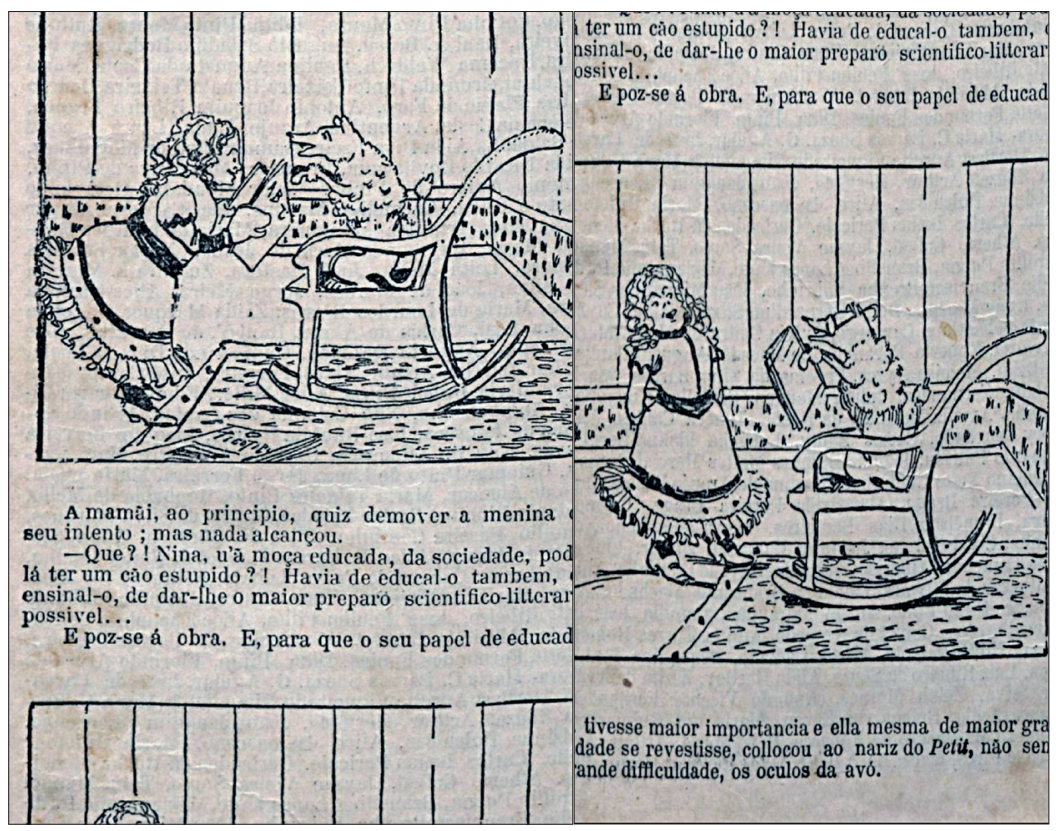

Figuras 4.I e 4.2. Imagens de Nina ensinando Petit a ler.

Fonte: $O$ Tico-Tico, II/4/1906, p. 3.

Como refletir acerca do jogo de imagem proposto pelo jornal seguido pela história de Nina? A nosso ver, há, claramente, uma tentativa de ressaltar a importância da escolarização, bem como a forma e a prática escolar.

Na primeira imagem, observamos Nina apoiando-se em alguns recursos, como livros e o próprio jornal O Tico-Tico, para ensinar seu cachorro Petit a ler. Além do suporte material, Nina também 
assume uma postura de professora. Inicialmente, comporta-se como uma professora dedicada ao aprendizado de seu "aluno" e, posteriormente, conforme evidenciado na segunda imagem, atua com mais autoridade. As imagens nos sugerem a relação aluno/ professor. Todavia, o texto que compóe a matéria do jornal anuncia náo somente a prática docente, como também sugere ao leitor a importância da escola, ao tentar relacionar as supostas "ignorância" e "indisciplina" de Petit à sua falta de consciência sobre o papel da instrução escolar na vida social.

Nessa direção, qual era a função d'O Tico-Tico ao disseminar a importância da escola? Pensamos que essa resposta perpassa o entendimento dos jornais como um mecanismo de propagação dos ensinamentos de boa conduta, civilidade e "adequação" social, configurando ainda um espaço de legitimação das práticas e formas de escolarização.

\subsection{Práticas de leitura para entretenimento e formaçáo escolar}

São fortes as evidências acerca das influências de pensamento proposto pelos articulistas das publicaçôes $O$ Malho e $O$ Tico-Tico. No entanto, elas não aparecem apartadas das apropriaçóes e dos modos de leitura que o público da revista O Tico-Tico fazia. Veja a poesia do menino Djalma Assis de Andrade enviada à redação da revista:

Mãi
Quem nas horas de tristezas,
Nos vem sempre acalentar,
Com um sorriso de anjo,
Que ninguém sabe imitar?
Quem nos ensina a ser bons, 
Para com a humanidade?

Quem nos ensina a falar,

Desde nossa tenra idade?

É a mãi, este ser sublime,

Que devemos sempre amar,

Si quisermos ser felizes,

Neste mundo de penar (O Tico-Tico, I2/9/1906, p. I3).

A "doce poesia" enviada para publicação aponta-nos para uma preocupação recorrente entre a sociedade republicana: o amor pela família. Entretanto, esse valor não é o único que podemos notar no texto do leitor Djalma. Convicçôes religiosas, educacionais e de bondade também podem ser observadas na poesia. Em seu desfecho, outra pista nos é transmitida pelo termo penar. O leitor, ao mencionar as penalizaçôes do mundo, sugere ter-se apropriado de conhecimentos acerca de práticas sociais que, ao serem transgredidas, acarretam punição e penalização por seu descumprimento.

É possível que os articulistas não desconhecessem esse tipo de apropriação. Pelo contrário, a nosso ver, isso fazia parte dos objetivos velados da publicação. Assim, para fazerem circular o impresso, eles convocavam a participação de seus leitores e até mesmo solicitavam suas opiniōes e críticas. Talvez essa seja uma estratégia para se aproximar deles e auferir recepçôes e simpatias.

Acreditamos, portanto, que o ato de ler é mais que uma "habilidade", tratando-se de um "conjunto de condiçóes histórico-sociais variáveis" (Darnton, I992, p. 2I8). Diante disso, percebe-se que a leitura não é estática, muito menos passiva. É um movimento de perspectivas, não linear, não podendo ser "ingênua, pré-cultural, longe de qualquer referência exterior a ela; pois ler é dar sentido de conjunto" (Goulemot, I996, p. I07). Assim, seguimos 
nosso exame para algumas colunas que podem apontar-nos outros indícios sobre as representaçóes nesse tipo de impresso.

Após a sua capa, a primeira matéria encontrada em O Tico-Tico registra histórias em quadrinhos, muito bem ilustradas, com cores fortes e desenhos marcantes, acompanhadas de textos curtos e frases simples. Em sua edição I, a história do personagem Frei Thomaz ocupa a primeira página, de modo a chamar a atenção dos leitores da publicação. Apesar de a revista apresentar-se deteriorada, é possível observar os recursos empregados pelos editores, gráficos e impressores, que servem para expressar a qualidade do material gráfico publicado e em circulação no começo do século XX. Tais elementos contribuem para entendermos melhor o investimento editorial e discursivo de O Tico-Tico em sua capacidade de atrair o público-leitor pretendido. 


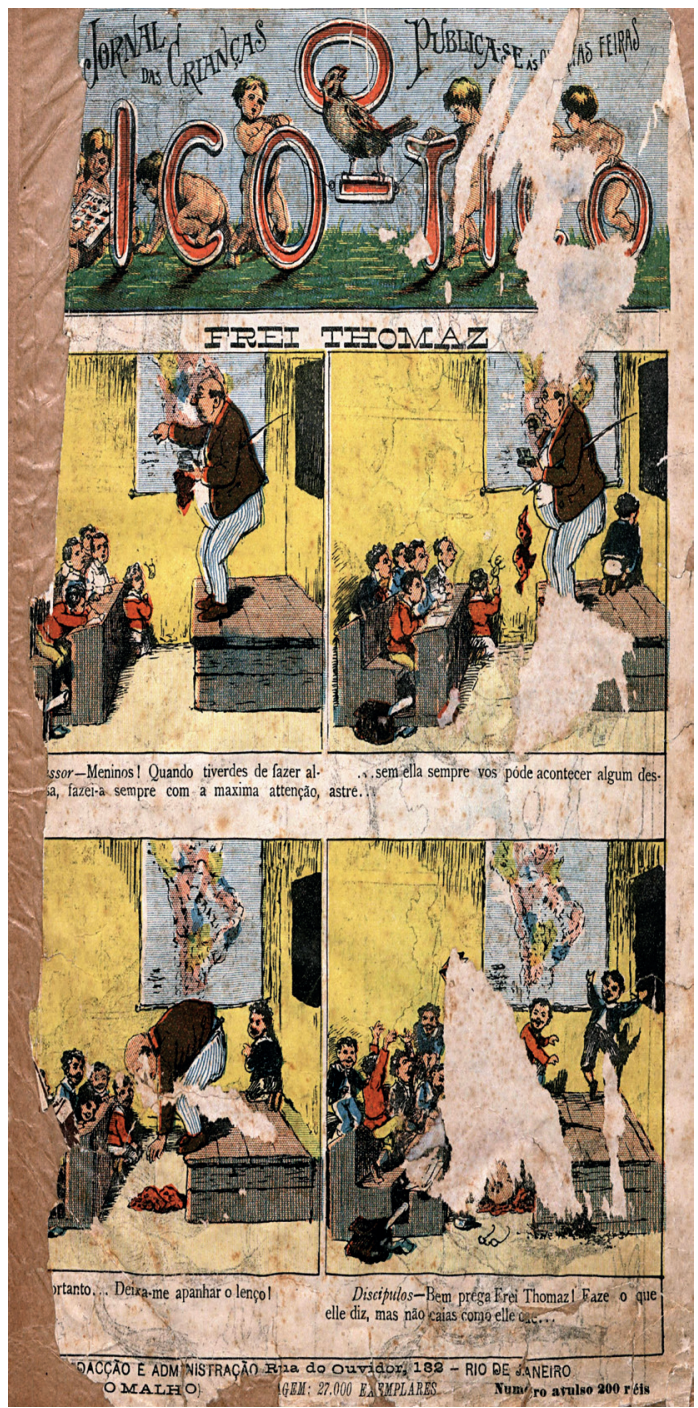

Figura 4.3. Primeira matéria encontrada no periódico O Tico-Tico. Fonte: O Tico-Tico, 22 de novembro de 1905. 
A história de Frei Thomaz descreve a situação rotineira de uma sala de aula no início do período republicano. $\mathrm{O}$ professor, em posição privilegiada e destacada, dá uma lição a seus alunos acerca da importância de se prestar atenção durante suas ações. No entanto, o quadrinho apresenta uma cena inusitada em que o professor expóe sua fala e, logo em seguida, leva um tombo, permitindo que seus alunos interpretem o evento como uma incoerência entre discurso e prática. Além da lição que a história claramente veicula, o material sugere índices subliminares não ditos pelos autores, os quais também transmitem informaçôes significativas. Observe-se que há uma criança de castigo no tablado mais elevado, onde o professor está posicionado. Assim como o professor se encontra em destaque, a criança, nesse mesmo lugar, também fica em destaque, embora ajoelhada e de costas para os outros alunos.

A cena ilustrada na publicação transmite uma mensagem clara acerca da disciplina e das puniçóes para quem desobedecesse às regras e não seguisse o comportamento imposto naquele ambiente. Os autores Júlia Varela e Alvarez-Uria remetem-nos para o processo de transformação proposto pelas instituiçóes disciplinadoras e pelos demais mecanismos de formação educacional. A educação desempenha o papel de fabricar sujeitos instruídos e cultos, mas também tem a função de "inculcar-lhes a virtude da obediência, modelando comportamentos" (Varela e Alvarez-Uria, I992, p. I3). Assim, quaisquer que fossem os meios de transmissão de cultura, o agente deveria atuar mais como "disseminador de uma mentalidade moralizante que como um difusor de conhecimento" (Villela, 2000, p. I26).

Entendendo o impresso como um meio de transmissão de cultura e do projeto de sociedade já mencionado, a título de materialidade, vale destacar o suporte oferecido a seu público. A aparência leve, colorida e divertida da revista pode ser considerada um me- 
canismo para despertar a atenção dos leitores, o que, a nosso ver, contribui para o almejado processo de aquisição de leitura. As imagens associadas aos pequenos textos proporcionavam aos leitores da revista $O$ Tico-Tico não somente momentos de diversão, embora esse fosse o elemento mais perceptível; elas possibilitavam também maior entendimento do texto. Portanto, há uma interferência na produção de sentidos por parte dos leitores em formação.

De modo "divertido", conforme os exemplos analisados indicam, as crianças recebiam as mensagens transmitidas pelos autores, agregando encantamento, aprendizado e valores morais. Alessandra El Far (2006) sugere-nos que as imagens podem imprimir mais impacto às cenas. Examinando seu uso nos jornais, a pesquisadora adverte para o fato de que a imagem facilita o exercício da leitura, deixando o texto mais leve e prazeroso. El Far esclarece ainda que a fotografia chegou na virada do século XIX para o século XX, e sua inserção se deu, em um primeiro momento, de maneira tímida. Não demorou muito, porém, para que passasse a fazer parte das notícias de destaque nos periódicos. Essa foi a maneira que os editores encontraram de oferecer uma pequena pausa aos leitores, em meio a uma profusão de textos. A nosso ver, significou mais do que isso. As imagens seriam instrumentos facilitadores e componentes indispensáveis para a alfabetização dos leitores, na medida em que poderiam favorecer a interpretação da linguagem verbal.

Deve-se, portanto, entender a formação do leitor, a partir das matérias de O Tico-Tico, no contexto da Primeira República e de um projeto de nação que se intentava colocar em prática. Assim, a transmissão das histórias não se dava de maneira desinteressada ou aleatória. Tampouco podemos pensar que isso também acontecesse com seus receptores.

Ler, envolver-se, participar das atividades lúdicas propostas pelo periódico, tudo isso revela a complexidade existente na lei- 
tura e na produção de sentidos. $\mathrm{O}$ ato de ler apresenta grande complexidade, pois nele estabelecemos relaçóes entre texto e contexto, entre palavra e mundo. A leitura é uma prática social e uma relação direta com a vida. Assim, a partir desse pressuposto, entendemos que:

[...] a vida em sociedade requer inúmeras e imprevisíveis ações dos sujeitos leitores: ler para nos informarmos das notícias diárias, para exercer atividades rotineiras como tomar um ônibus, escolher direçôes da cidade; também para entretenimento, para acompanhar a charge do jornal diário, os quadrinhos ou as colunas sociais e notícias que, com frequência utilizam a piada, a ironia, de modo a colocar pelo avesso a realidade circundante (Silva e Martins, 20I0, p. 9).

Como os leitores viram essa realidade pelo avesso? Acreditamos que a resposta esteja em suas práticas de leitura. Configura-se, desse modo, o avesso a partir das formas de apropriação por eles inventadas (Silva, 20II).

É preciso notar que o público-leitor não tem uma atitude passiva na recepção do "jornal da criança”. Na coluna "Gaiola d' $O$ Tico-Tico", há contato direto entre autor e leitor. As crianças leitoras da publicação utilizam desse espaço para se inserir na trama do periódico. Elas dão suas opiniões, enviam cartas, escrevem poemas e ainda expóem suas impressóes acerca das histórias e dos personagens.

Nessa coluna, em in de setembro de 1906, publicava-se o poema escrito pelo correspondente João Galero de Pelotas (RS), que se dirigia a um dos principais personagens encontrados nas historinhas da publicação: o menino Chiquinho, que era, recorrentemente, retratado em uma história repleta de travessuras, peraltices, seguidas por correção física, disciplinar ou moral. Entretanto, 
como João se apropria da imagem de Chiquinho? Para uma observação mais acurada dessa relação, destacamos os versos a seguir:

Chiquinho, tu és travesso, Porém um bom estudante A se julgar pelo número De livros na tua estante.

Chiquinho, pelo retrato, Pequeno, como tu és.

Para chegares a meza

Corta-lhes os pés.

(O Tico-Tico, 19/9/1906, p. II).

O poema de João indica o modo como ele percebe o personagem. Não negando a principal característica de Chiquinho, o leitor argumenta que o menino é travesso. Porém, atribui, em acréscimo, valores sociais esperados e desejados em uma criança no período examinado. Note-se que Chiquinho é peralta e "um bom estudante". Nesse sentido, embora as notícias em O Tico-Tico construam um estereótipo específico para o personagem, as fotografias e as imagens associadas às histórias de Chiquinho possibilitavam ao leitor ter uma nova visão, receber outra mensagem. 


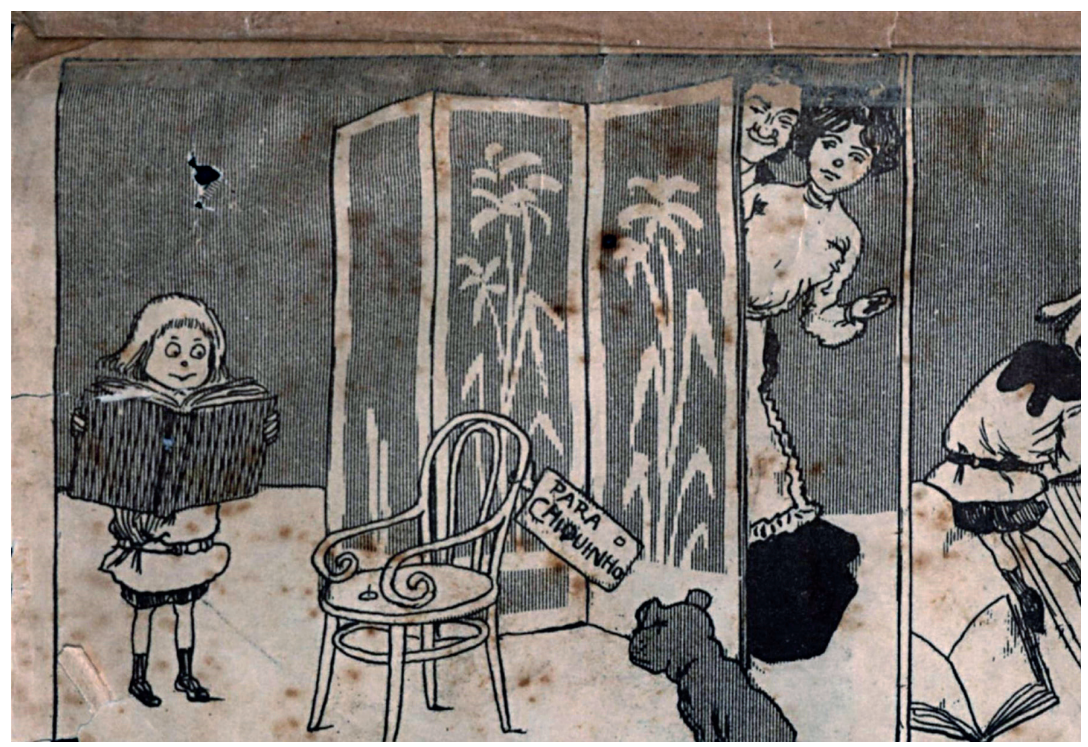

Figura 4.4. Imagem de Chiquinho lendo antes de iniciar suas peraltices. Fonte: O Tico-Tico, Io/1/1906, p. 5.

João conseguiu identificar outra característica a partir dos suportes oferecidos pelo autor. As cenas em que Chiquinho estava na escola, os enredos que apresentavam o menino com livros em sua casa, tudo isso contribuiu para o leitor formar sua opiniáo sobre o personagem, ultrapassando a transmissão do autor. É possível constatar essa afirmação, inclusive, a partir da representação feita por um segundo leitor, Laurindo Corrêa Malheiros, que desenha Chiquinho na escola, dedicando-se aos estudos matemáticos supostamente necessários à vida social. 


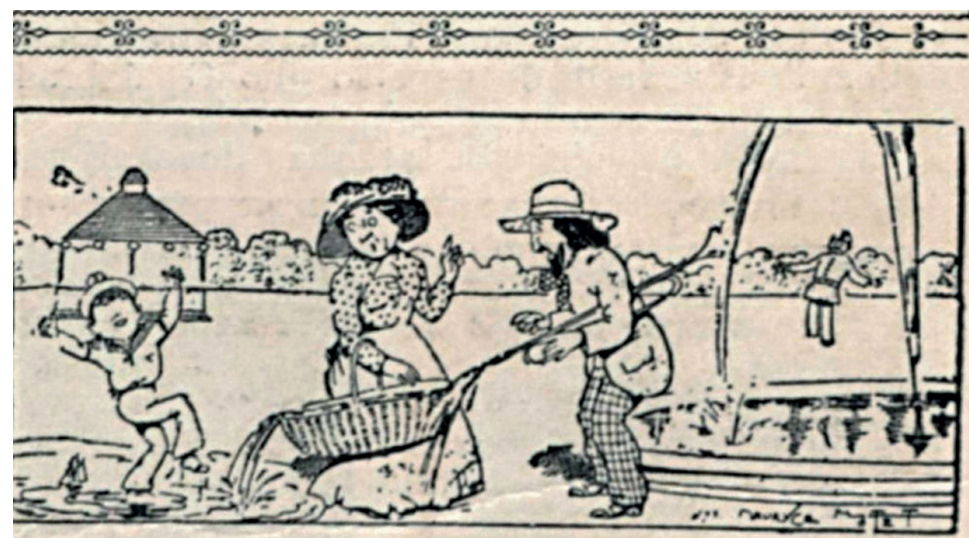

3) ... e que a agua, tocada pelo vento, passava pelo larim á cesta, molhando as compras e formando assim im excellente lago para o navio de Manduquinha...

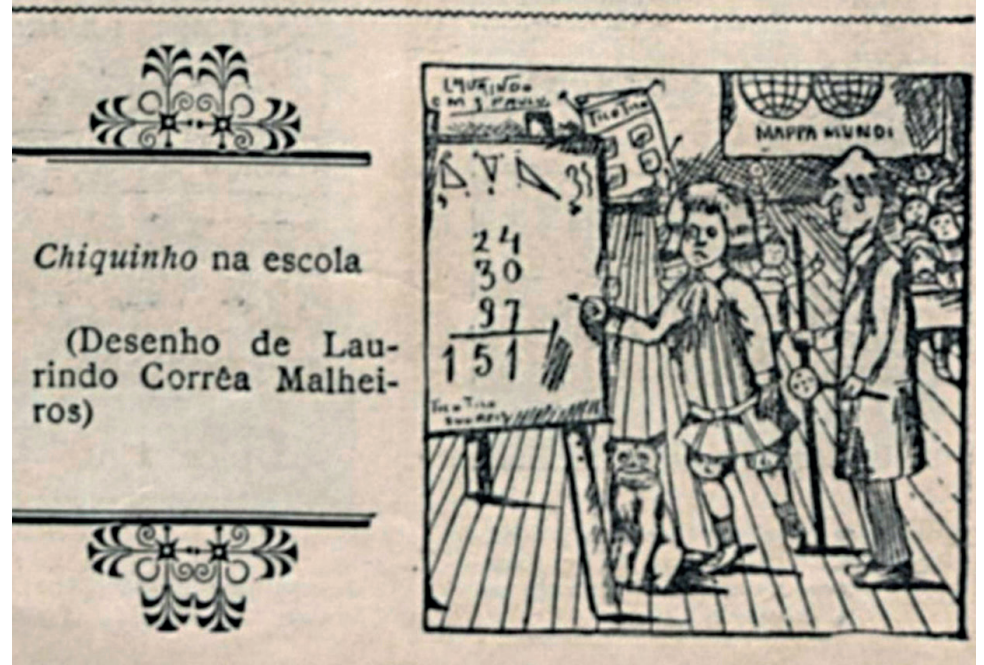

Figura 4.5. Representação de Chiquinho por um leitor. Fonte: O Tico-Tico, 2I/9/1910, p. 6. 
Para Roger Chartier (I999), a leitura "é sempre apropriação, invenção e produção de significados” (p. 77), e toda a história da leitura deve supor, desde o princípio, que o leitor tem a liberdade de deslocar e subverter o que o texto, de forma geral, pretende lhe impor.

Em diálogo com Certeau (I994), o que se pretende é justamente romper com o postulado clássico advindo da história social que coloca a imposição do sentido e o poder ideológico no texto quase como verdades axiomáticas no tocante à leitura, atribuindo aos autores a onipotência sobre todo o processo de ler e escrever. Para Certeau, a presença e a circulação de uma representação não indicam, de modo algum, o que ela é para seus usuários. É ainda necessário analisar "a sua manipulação pelos praticantes que não a fabricaram” (Certeau, I994, p. 40). Ou seja, Chiquinho não é o mesmo para seus autores e para João. O leitor observa o personagem como levado, mas também estudioso. A revista, portanto, reforça as peraltices de Chiquinho e sugere penalizaçóes por sua conduta "inadequada”. A consideração exposta permite pensarmos os signos atribuídos à leitura de João. Ele compreende a mensagem de indisciplina transmitida pelo jornal, mas também acrescenta uma nova representação do personagem a partir de seu olhar.

Em janeiro de 1907, a redação d'O Tico-Tico lançava a coluna "O Sr. X e sua página”. Nela, cumprimentando seus "leitorzinhos”, a fim de alcançar "a sympathia e o favor do seu amável público", o articulista solicitava a exposição de "habilidades, caricaturas, anecdotas, adivinhaçóes, enigmas, jogos e brincadeiras" (O Tico-Tico, 9/I/I907, p. II). 


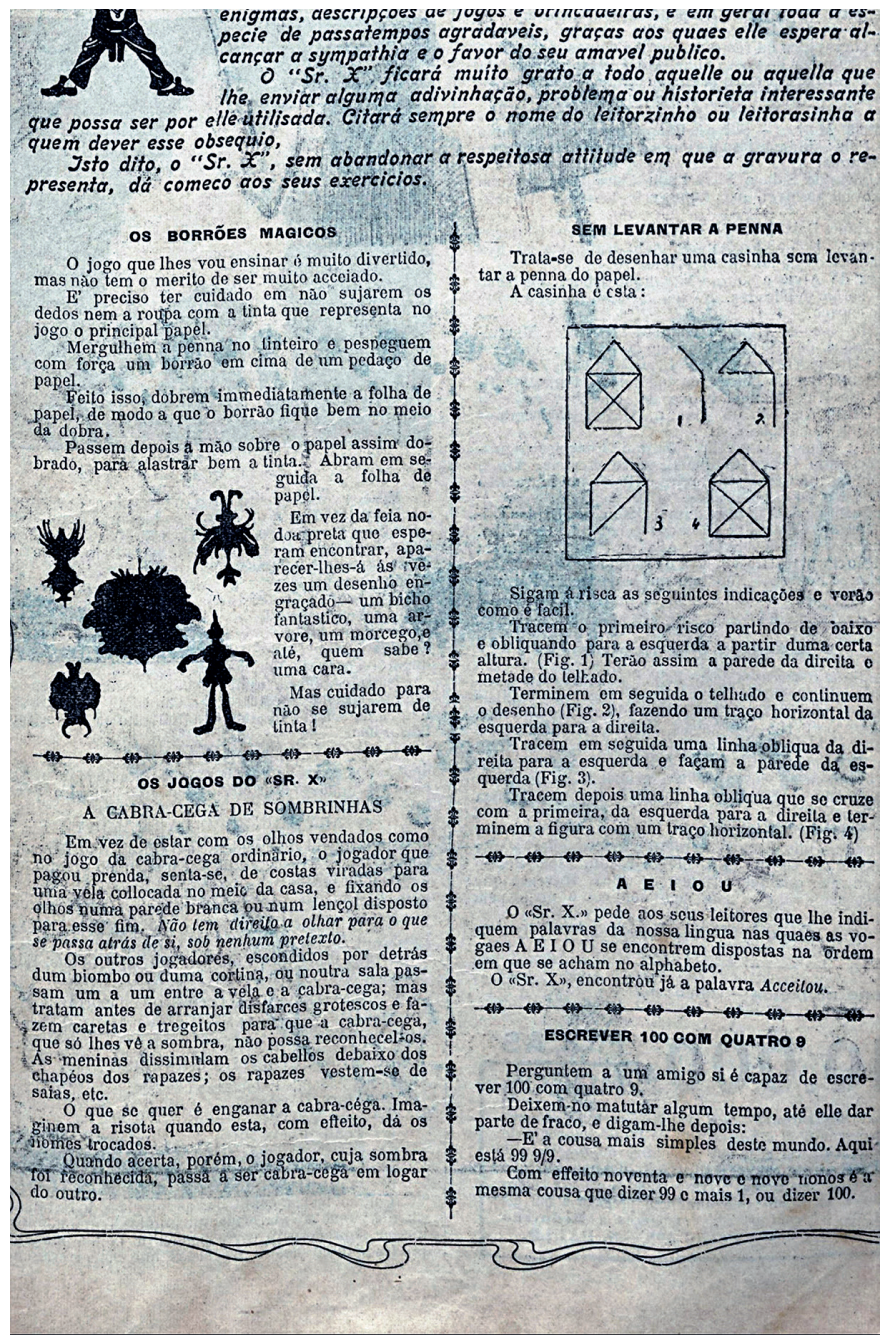

Figura 4.6. Coluna O Sr. X e a sua página.

Fonte: O Tico-Tico, 9/I/1907, p. II. 
De antemão, a forma escolar é perceptível na matéria destacada. Incentivo à leitura, coordenação motora, conteúdo curricular das disciplinas de português e matemática anunciam o olhar educativo e pedagógico do jornal, tanto nas práticas formais como nas informais, embora relacionadas ao espaço escolar. Contudo, verificamos outros interesses anunciados no jornal. Por meio dos desafios propostos aos leitores, os articulistas não somente conseguiam intervir na aprendizagem das crianças, como também convidar as crianças para que continuassem a ler os exemplares seguintes, aguardando as respostas às questóes. Ao convocar a participação delas, a redação estabelecia uma relação autor-leitor, estimulava os novos leitores e recorria a esse artifício para vender mais jornais, aumentando, assim, sua circulação e disseminando seu interesse pela formação social.

As estratégias obedecem a um balanço de relação de forças, empreendido por um sujeito que detém algum tipo de poder e que "postula um lugar capaz de ser circunscrito como um próprio e, portanto, capaz de servir de base a uma gestão de suas relaçôes com uma exterioridade distinta" (Certeau, 1994, p. 46). Visa, assim, produzir, mapear e impor adágios e opinióes em torno de uma influência que se almeja inculcar.

No entanto, não obstante as estratégias desenvolvidas a partir da escrita de um autor, observa-se também uma relação não menos significativa entre as palavras escritas e as inimagináveis formas de leitura e interpretação de uma história. A intensidade de um texto surge quando os olhos estabelecem contato com as marcas da escrita. Nos mais variados suportes, um texto pode ser considerado incompleto sem a existência do leitor. A escrita faz do escritor um inventor de mensagens ou até mesmo um criador de signos. Isso serve para refletirmos sobre a escrita e as intencionalidades de seu autor, porém também nos leva a pensar que 
os textos, os signos ou as mensagens precisam de alguém que os decifre, que lhes dê voz.

Outra estratégia notável por parte dos articulistas consistia na publicação de fotos e correspondência de seus leitores. Essa veiculação não acontecia por acaso. Acreditamos que há uma intencionalidade a mais na ação, uma vez que esse fato sugere, eventualmente, uma sensação de vínculo, de compromisso e, até mesmo, de familiaridade entre autor e leitor. Tratava-se de práticas recorrentes no periódico que poderiam produzir efeito na recepçáo e na apropriação por parte das crianças e de seus responsáveis.

A constatação pode ser corroborada pela participação em concursos promovidos pela revista. No concurso de Natal "Que é o que o menino ou a menina mais desejam no novo anno de 1906 ", um total de 556 leitores enviou resposta à questão solicitada (O Tico-Tico, 3/1/1906, p. 8). Esse número foi ampliado para mais de 960 participantes no concurso $n^{\circ} 24$, "que pedia aos leitores para escreverem demonstrando o seu sentimento profundo pela dolorosa tragédia da explosão daquelle couraçado brasileiro", pouco tempo depois $(O$ Tico-Tico, 2I/2/1906). Nesse último concurso, foram premiadas $4 \mathrm{I}$ "bravas petizadas", enquanto, no concurso no I69, "Proclamaçáo da República”, de 20 de novembro de 1907 , foram premiados I23 acertadores (Idem, 20/II/1907, p. I2). Constata-se, assim, que o aumento de participaçóes é expressivo, mas que também é expressiva a necessidade de o "jornal da criança" divulgar o nome dos envolvidos e dos ganhadores. Esses aspectos levam-nos a inferir duas questôes: a significativa divulgaçáo no sentido de atrair leitores e a participação desses leitores, inserindo-se ativamente no processo de leitura, no qual representam peça fundamental.

Esse processo, a propósito, merece maior reflexão. Roger Chartier (1990), ao descrever a noção de "apropriação", no sentido de uma abordagem cara à história cultural, propõe "uma história social das interpretações, remetidas para as suas determinaçóes 
fundamentais" (pp. 28-9). O autor compreende que a história deveria dirigir-se "[...] às práticas que, pluralmente, contraditoriamente, dão significado ao mundo" (idem, ibidem), guiando, assim, nossa análise para as múltiplas interpretaçôes, próprias das práticas culturais e sociais, que também são diversas e instáveis.

\section{3 $\mathrm{E}$ os leitores se tornam autores...}

Em seus cinco primeiros anos, O Tico-Tico publicou, na seção intitulada "Senhor X", diversos contos produzidos por seus leitores. Por meio desse exame, é possível vislumbrar as vozes desses leitores, bem como perceber o tipo de literatura que fazia parte da formação desses jovens e crianças.

Em geral, as crianças desses contos são sempre obedientes aos adultos, bondosas, gentis e estudiosas. Os personagens que destoam desses predicativos sofrem, em geral, algum tipo de punição ou lição de moral. Isso é o que se vê em "Exemplo Maternal", assinado pelo leitor Romeu de Lima Leal, de Io anos (O Tico-Tico, 3/3/1909, p. Io). O conto é pequeno, desenvolvido em algumas poucas linhas. Traz a história de um menino e de sua máe que, após a morte do pai, viviam em uma cabana pobre. Contudo, embora pobres, os personagens são descritos como felizes, pois o mais importante era o amor da mãe por seu filho. Certo dia, a fortuna bate à porta do casebre:

[...] Uma vez, casualmente, a fortuna entrou-lhe pela porta e disse, em tom irônico e zombeteiro: um filho bom e dedicado não deve viver na escuridão. Anda, partamos, abandona a tua mãe, luta pela vida e verás como em breve serás um pachá!

- Eu? Abandonar minha choupana singela para habitar em palácios e deixar isolado o meu anjo tutelar, isso nunca! Siga o teu caminho tortuoso e estreito, que a felicidade não consiste em castelos de már- 
mores dourados, não! Enganas-te! A felicidade é a paz, é o amor sublime que devemos ter aos nossos pais!! E hoje, quando passamos n'esse recanto e ouvimos o dobrar tristonho do sino da igreja, vimos aquele par ditoso caminhando alegremente, de mãos dadas, subir os degraus da capela para invocar à Virgem suas perpetuas felicidades!!! (O Tico-Tico, 3/3/1909, p. Iо).

Nessa passagem, é possível observar que, para o personagem, o importante era o sentimento de amor familiar, pois dele derivava a felicidade. $\mathrm{O}$ personagem (descrito como um bom filho) tem, no amor pela mãe, sua verdadeira felicidade. Esse, contudo, não é o único conto em que o amor pelos familiares (em geral, a família apresentada é a nuclear burguesa, com mãe, pai e filhos) aparece acima dos interesses pessoais.

Alguns contos escritos para a mesma seção apresentam características semelhantes. Outro exemplo é o escrito por E. Wanderley, intitulado "Amor Filial". No conto, o personagem Agostinho, um menino pobre, recebe a medalha de melhor aluno do ano (O Tico-Tico, I2/I/I9ıo, pp. I6-7). Todavia, com sua mãe doente, a criança tenta penhorar a medalha para comprar os remédios de que ela, adoentada, necessita. Após algumas dificuldades, o menino não só consegue o dinheiro para o remédio, como também fica com a medalha, como recompensa por sua abnegação.

Em estudo sobre a história da literatura infantil brasileira, Lajolo e Zilberman trazem uma análise do contexto nos anos iniciais do século XX. Segundo as autoras, esses primeiros anos da República foram marcados por projetos que visavam formar os novos cidadãos. Dessa feita, concomitantemente à ampliação das escolas públicas, houve necessidade de criar materiais que pudessem ajudar no processo de formação desses jovens e crianças (Zilberman e Lajolo, 2009, p. 2I). 
Os livros escritos nesse período (I900-I920) caracterizam-se por preocupaçóes explícita ou implicitamente pedagógicas, tanto por apresentar histórias com crianças de comportamento exemplar (exaltando a obediência aos adultos e sentimentos socialmente valorizados, como caridade, amizade e justiça) como por trazer textos com linguagem formal, semelhante àquela aprendida nas escolas. Essas representaçôes da infância estavam relacionadas a um projeto político-social mais amplo, cujo objetivo era formar os futuros cidadãos. Assim, tais livros, em sua maioria, eram lidos por crianças e jovens, e veiculavam determinadas representações sobre uma infância que "deveria ser". O amor à família e à pátria, a prática de boas açóes e, sobretudo, o sacrifício dos interesses pessoais pelo coletivo eram preocupaçóes recorrentes.

De modo velado ou não, nesse período os livros dedicados às crianças têm a preocupação de prepará-las, desde a mais tenra idade, para a vida adulta. Por isso não é incomum que, nos livros de literatura infantil com apelação nacionalista, como Através do Brasil (I9Io), de Olavo Bilac e Manuel de Bonfim, e Contos pátrios (1904), de Olavo Bilac e Coelho Neto, apareçam personagens em sua fase infantil, que, a partir dos II ou I2 anos, adquirem um comportamento socialmente atribuído aos adultos, como, por exemplo, a preocupação com o trabalho e com a família (Zilberman e Lajolo, 2009, p. 30).

Vale ressaltar que esse tipo de literatura aponta para uma concepção de infância desenvolvida ao longo do século XVIII, desde a ascensão da burguesia. A criança passou, então, a ser percebida como o ser do "devir", ainda em formação, e que necessitava de açôes educativas específicas. Diante disso, desde o século XVIII, o livro infantil "configurou-se como aliado deste projeto burguês de educação, preocupado com a perpetuação de valores e representaçôes sociais" (Silva, 20II, p. 37). Assim, pequenas histórias com essas características são uma constante nas ediçóes analisadas de 
O Tico-Tico. É possível, portanto, vislumbrar o sistema de representação do ideal de infância que estava vinculado à literatura infantil na época. Esses contos publicados pela revista possibilitam-nos entrever as experiências dessas crianças como leitoras. Os livros escritos apontavam para uma preocupação com a formaçáo dos cidadãos, que deveriam privilegiar determinados comportamentos.

Roger Chartier (1999), ao examinar as práticas de leitura e o leitor ao longo da história, pondera que, não podendo o historiador conhecer o passado tal qual ocorreu, só lhe resta observar, por meio das fontes, as mudanças havidas nos sistemas de representação (p. 82). Dessa forma, não se sabe ao certo se, no caso dos livros infantis, as crianças passavam a se comportar de forma exemplar, mas, sem dúvida, esses padróes de comportamento eram valorizados nos personagens de livros e textos destinados a crianças.

A análise dos contos enviados à publicação pelos jovens leitores se faz oportuna. Nessas histórias, as vozes das crianças se fazem presentes, e, com elas, é possível observar alguns modos como essas crianças se apropriaram dos discursos educativos e moralizantes veiculados pelos livros infantis do período. Aproximando-se, consideravelmente, das práticas escolares, por meio de textos e redaçôes, o jornal despertava, nas crianças, a vontade e a necessidade de se expressar com a linguagem escrita, principalmente por meio dos ideais civilizatórios. No entanto, também encontramos histórias que não seguiam essas características. Nelas, as crianças se expressavam sem a preocupação de construir personagens, histórias exemplares ou de se adequar aos padróes estabelecidos.

Entre os contos desprovidos dessa preocupação pedagógica, está aquele escrito por Amanda de Toledo, de I2 anos. A história gira em torno da destruição de sua boneca preferida por um menino da vizinhança. Rompendo com outros contos em que as 
crianças apresentam comportamento exemplar, a menina expóe sua reação ao deparar com a situação mencionada:

[...] Quando chegamos, era já tarde. O cruel, com a boneca na mão, ria, inconsciente. Havia retorcido as pernas e os braços da pobrezita e agora procurava arrancar-lhe os olhos e os cabelos.

Loucas de raiva, eu e Laura caímos sobre o patife e demos-lhe tanta pancada que o brutinho deitou a correr para a casa, com o nariz esguichando sangue, num berreiro infernal (O Tico-Tico, 25/8/1909, p. 20).

Nesse conto, é possível vislumbrar a voz da criança sem que manifeste a preocupação em atender àquilo que Sônia Salomão Khede (I986) chama de "expectativas adultocêntricas" (p. 25). Com essa expressão, Khede refere-se ao tipo de história ou de personagem que os adultos esperam integrar um livro para crianças. No caso da literatura infantil dos primeiros anos do século XX, esperava-se, em geral, que os contos infantis transmitissem valores morais (bondade, abnegação, obediência aos adultos e amor pelos estudos). Essas expectativas podem ser observadas tanto em contos escritos por adultos para crianças (como o caso de Através do Brasil, de Olavo Bilac e Manuel de Bonfim) como nas histórias criadas por crianças e enviadas a O Tico-Tico.

Além de não representar a si mesma no conto como uma menina exemplar, a jovem autora também cria um desfecho para sua história que rompe com a maior parte das histórias de leitores publicadas na revista. Ao longo das ediçóes analisadas, percebemos que tanto as histórias publicadas pelos redatores (histórias ilustradas, como as "Aventuras de Chiquinho" e "Contos Maravilhosos") como aquelas enviadas pelos leitores apresentam uma estrutura binária, maniqueísta. Assim, personagens que têm as qualidades esperadas sempre são recompensados no 
fim da história. Do mesmo modo, aqueles que agem de uma forma considerada errada, desonesta e fora dos padróes morais sempre são castigados. No conto escrito pela menina Amanda, contudo, há um rompimento com esse padrão, como podemos observar no trecho a seguir:

Cinco minutos depois entra a mãe de Julio, a nos dirigir investidas. O negócio se complicava.

Mamáe, que ouvira a voz da visinha, veio pedir-lhe explicaçóes. Repreendeu-nos, prometeu castigar-me, o que não fez, graças a intervenção de Laura, que, debulhada em lágrimas, pediu-lhe que me desculpasse (O Tico-Tico, 25/8/1909, p. 20).

No final da história, mesmo criando indisposição com a família vizinha por ter agredido o menino (o que a distanciava do modelo de criança e, sobretudo, de menina exemplar), a criança é perdoada. $\mathrm{O}$ castigo não se dá, segundo ela, pela interferência de uma amiguinha. As reflexôes de Walter Benjamin sobre a criança e o universo infantil se fazem oportunas. Segundo ele, as crianças também são sujeitos capazes de se apropriar do mundo adulto, criando novas lógicas. Elas "estão menos empenhadas em reproduzir as obras dos adultos do que estabelecer uma relação nova [...] com esses restos e materiais residuais" (Benjamin, 2009, p. 58). A nosso ver, a criança parece apresentar a capacidade de subverter uma lógica habitual ou esperada pelos adultos e criar outra, que agrada mais a ela. A lógica mais comum dos contos apresentados é que um comportamento impróprio (nesse caso, agredir o colega) deve ser castigado, o que, contudo, não ocorre.

As histórias escritas por crianças e publicadas na revista não são fortuitas. Além de apontar uma estratégia de aproximação com o público-leitor, vislumbra o projeto educativo vinculado pelos editores da revista. Além disso, o espaço aberto ao público infantil 
permite-nos analisar os modos de representação social das crianças leitoras da revista, bem como o tipo de literatura possivelmente lido por elas.

\section{Consideraçóes finais}

Criada no momento em que o Brasil tentava construir seu modelo republicano, a revista $O$ Tico-Tico pode ser entendida como um periódico a serviço de um projeto social. Como bem nos aponta Waldomiro Vergueiro (2008), o "jornal da criança" trouxe entretenimento e lazer, mas "náo o fez de maneira inocente, pois buscava formar um determinado tipo de cidadão e louvar um padrão de comportamento" (p. 23).

Enquanto a expansão da malha escolar consistia em uma preocupação social disseminada entre os discursos políticos e aqueles circulados na imprensa, a revista representava um espaço não formal de educação. No entanto, embora não formal, de algum modo ela estava próxima das novas ideias de formaçáo dos cidadãos, por meio da escolarização. Tal percepção vai ao encontro da afirmação de Zita Rosa (2002), ao refletir sobre as intenções dos responsáveis por O Tico-Tico: "em imprimir à publicação um caráter utilitário", levando-os "a acalentar um projeto pedagógico atrelado à ideia de progresso" (p. I08).

Nesse sentido, é possível perceber, a partir da análise traçada, que $O$ Tico-Tico exibe algumas representaçóes da escola primária proposta no Império e idealizada no início da República. A forma escolar republicana pode ser encontrada sob diferentes roupagens: na história de Frei Tomaz, em que aparece a configuração usual de uma sala de aula (disposição das carteiras, dos alunos, do professor e dos objetos didáticos); nos jogos, charadas e desafios lançados pela coluna "O Sr. X", que se assemelhavam aos exercícios trazidos nos livros de leitura e manuais de matemática adota- 
dos pelas escolas à época; na história de Nina e seu cachorro Petit, que reproduz um imaginário em torno das práticas pedagógicas.

Por forma escolar, entendemos a configuração apresentada pelas práticas educativas formais, mais comumente observadas na instituição escolar. Durante a República, buscou-se implementar uma nova organização escolar, que passou a conceber e projetar na escola a ideia e o simbolismo da modernidade, próprios da República. Embora outras formas de organização escolar possam ser observadas nesse período, como ponderam Alessandra Schueler e Ana Magaldi (2009), verificamos que a forma estabelecida no início do século XX foi de uma escola dita moderna, construída e organizada sobre preceitos higienistas, médicos e pedagógicos (constituída por séries que variavam de acordo com a idade dos alunos; com um tempo de funcionamento próprio, com disciplinas específicas etc.).

Esse imaginário escolar, propiciado pela ideia de modernidade, progresso e civilização, pode ser observado em algumas passagens trazidas nas matérias de O Tico-Tico. Ademais, algumas das histórias enviadas pelos leitores também apresentam indícios dessa escola republicana. No conto enviado por E. Wanderley, o personagem é descrito como o melhor aluno da classe, que recebe uma medalha pela aplicação aos estudos. $\mathrm{O}$ ato de premiar, no final do ano letivo, os alunos exemplares era uma característica de algumas escolas públicas primárias. Essa prática aparece nas biografias e nos estudos realizados, por exemplo, sobre a poetisa Cecília Meireles, que, em I9IO, recebeu do então diretor de Instruçáo Pública, Olavo Bilac, uma medalha por seu desempenho escolar. ${ }^{8}$ Nota-se, entáo, que os elementos da cultura escolar são apresentados e va-

8 Sobre a criação da Biblioteca Infantil Pavilhâo Mourisco, dirigida pela poetisa Cecília Meireles, Jussara Pimenta (20II) aponta-nos o episódio da vida escolar da poetisa e diretora da biblioteca em que, aos 9 anos, recebeu uma medalha como prêmio por seu desempenho escolar. 
lorizados (ao menos, aparentemente) até mesmo pelos leitores que enviavam contos para o "jornal da criança”.

Lançando mão de estratégias editoriais como, por exemplo, aproximação com seus leitores, histórias ilustradas, contos clássicos, matérias pedagógicas, informaçóes gerais e brincadeiras, O Tico-Tico apresentou, escamoteadas ou não, representaçóes de pensamentos comuns em uma sociedade em transformação e em pleno processo de modernizaçáo, bem como uma sociedade fortemente marcada pelas práticas e pela forma escolar. Além disso, inculcou hábitos moralizantes e condutas sociais "adequadas", proporcionando um novo jeito de divertir, educar e civilizar.

\section{Fontes}

\section{Periódicos}

Correio de Minas, 1906.

O Imparcial, I915.

O Malho, 1905.

O Tico-Tico, 1905-I9Io.

\section{Referências}

BELLO, Oliveira. Imprensa Nacional: apontamentos históricos. Rio de Janeiro: Imprensa Nacional, 1908.

BENJAMIN, Walter. Reflexōes sobre a criança, o brinquedo e a educação. São Paulo: Editora 34, 2009.

CERTEAU, Michel. A invenção do cotidiano: artes de fazer. Petrópolis: Vozes, v. I, I994.

CHARTIER, Roger. A história cultural: entre práticas e representaçôes. Rio de Janeiro: Bertrand Brasil, I990. 
. A aventura do livro: do leitor ao navegador. São Paulo: Fundação Editora da Unesp, 1999.

DARNTON, Robert. "Uma história da leitura". In BURKE, Peter. A escrita da história: novas perspectivas. São Paulo: Cia. das Letras, 1992.

EL FAR, Alessandra. O livro e a leitura no Brasil. Rio de Janeiro: Jorge Zahar Editor, 2006.

FARIA FILHO, Luciano Mendes e VIDAL, Diana. "Os tempos e os espaços escolares no processo de institucionalização da escola primária no Brasil”. Revista Brasileira de Educação, n. I4, 2000, pp. 19-34.

GONÇALVES, Roberta Ferreira. A escola disfarçada e brincadeiras: intelectuais e ideias na criação da revista O Tico-Tico (dissertação). UERJ, $20 I I$.

GONDRA, José Gonçalves e SCHUELER, Alessandra. Educação, poder e sociedade no Império Brasileiro. São Paulo: Cortez, 2008.

GOULEMOT, Jean Marie. "Da leitura como produção de sentido”. In CHARTIER, Roger. Práticas de leitura. São Paulo: Estação Liberdade, 1996.

KHÈDE, Sonia Salomão. Personagens da literatura infantojuvenil. São Paulo: Ática, 1990.

PIMENTA, Jussara Santos. Leitura, arte e educação: a biblioteca infantil do Pavilhão Mourisco (1934-I937). Curitiba: CRV Editora, 20II.

ROSA, Zita de Paula. O Tico-Tico: meio século de ação recreativa e pedagógica. Bragança Paulista: EDUSF, 2002.

SCHUELER, Alessandra e MAGALDI, Ana Maria de Mello. "Educação escolar na Primeira República: memória, história e perspectivas de pesquisa”. Tempo, 2009, v. 13, pp. 43-66.

SILVA, Márcia Cabral da. "A circulação de textos literários entre crianças e jovens na sociedade contemporânea”. Revista Fronteira Z, São Paulo, n. 6, abr. 2OII, pp. I-II.

. Infância e literatura. Rio de Janeiro: EdUERJ, 20II, pp. 20-39. . e MARTINS, Milena Ribeiro. "Experiências de leitura no contexto escolar”. In PAIVA, Aparecida et al. (orgs.). Literatura: ensino fundamental. Brasília: Ministério da Educação/Secretaria de Educação Básica, 2oı, v. 20, pp. 23-40. (Coleção Explorando o Ensino) 
132 Literatura, Leitura e Educação

VARELA, Júlia e ALVAREZ-URIA, Fernando. A maquinaria escolar: teoria e educação. Trad. Guacira Lopes Louro. S.1., I992, pp. I-I7.

VERGUEIRO, Waldomiro. "O Tico-Tico: uma análise da primeira revista brasileira de histórias em quadrinhos”. Comunicação \& Educação, maio/ ago. 2008, n. 2, ano XIII, pp. 23-34.

VILLELA, Heloisa. "O mestre-escola e a professora". In LOPES, Eliane Martha et al. (orgs.). 500 anos de Educação no Brasil. Belo Horizonte: Autêntica, 2000.

VINCENT, Guy et al. "Sobre a história e teoria da forma escolar". Educação em Revista, Belo Horizonte, n. 33, pp. 7-48, jun. 200 I.

ZILBERMAN, Regina e LAJOLO, Marisa. Literatura infantil brasileira: história \& histórias. São Paulo: Ática, 2007. 


\title{
5
}

\section{Estória do galo e do Candimba, de Leonardo Arroyo (1961): contradições e renovação na literatura infantil brasileira}

\author{
Vivianny Bessão de Assis
}

\section{Introdução}

Com o objetivo de contribuir para a produção de história, teoria e crítica específicas da literatura infantil e compreender o lugar ocupado por Leonardo Arroyo (I918-1985) em tudo isso, focalizamos, neste texto, ${ }^{\mathrm{I}}$ aspectos de sua produçáo escrita relacionada à produção de literatura infantil publicada na década de 1960, no Brasil.

Trata-se de uma pesquisa de abordagem histórica, que não visa a um julgamento de valor nem à assunção do ponto de vista defendido pelos sujeitos envolvidos. O objetivo deste texto é compreender as concretizaçóes e tematizaçóes (Mortatti, 2000) em relação à literatura infantil e juvenil, produzidas por um sujeito de outra época, influenciado pela produção sobre e de literatura infantil até então.

\footnotetext{
I Este texto resulta de pesquisa de doutorado (bolsa Capes), desenvolvida junta ao Programa de Pós-Graduação em Educação da Faculdade de Filosofia e Ciências, da Universidade Estadual Pau-

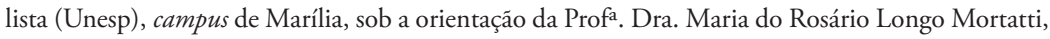
e vinculada ao Grupo de Pesquisa "História do Ensino de Língua e Literatura no Brasil" e ao Projeto Integrado de Pesquisa "História do Ensino de Língua e Literatura no Brasil” (PIPHELLB), ambos coordenados pela professora mencionada. O GPHELLB está em funcionamento desde 1994, cadastrado no diretório dos grupos de pesquisa do Brasil - CNPq e certificado pela Unesp.
} 
Assim, sem enquadrá-lo nos parâmetros do presente, buscamos compreender os aspectos envolvidos na produçáo de literatura infantil de Leonardo Arroyo, a partir de seu livro Estória do galo e do Candimba (196I), publicado na Coleção Verdes Anos, da Editora Melhoramentos (SP). Igualmente, procura-se compreender suas relaçóes com a época de produçáo, reconhecendo os sentidos que podem contribuir para o enfrentamento dos problemas do presente e construção do futuro da literatura infantil e juvenil em nosso país.

Com Estória do galo e do Candimba, Leonardo Arroyo (196I) contribui para a constituição de uma literatura infantil brasileira, produzida e publicada por uma editora que, à época, priorizava a publicação de livros voltados a crianças, empreendendo, de modo pioneiro, a difusão e a nacionalização de cartilhas, livros de leitura e de teorias educacionais, e investindo no aprimoramento gráfico e na ampliação do circuito de comercialização de livros.

Em 196I, ano em que o livro Estória do galo e do Candimba foi publicado, Manuel Bergströn Lourenço Filho estava à frente do trabalho editorial da Editora Melhoramentos (SP). Considerado especialista no assunto de leitura, literatura e crianças, emitia pareceres sobre livros de literatura infantil, participava como júri de concursos nessa área e dirigia a coleção "Biblioteca infantil", idealizada por Arnaldo de Oliveira Barreto, em I9I5, e coordenada por ele a partir de 1927 (Donato, 1990).

O período compreendido entre as décadas de 1940 e 1960 foi marcado pelo desenvolvimento da indústria editorial e pela expansão da escola brasileira. Desde então, aumenta-se a produçáo de livros para atender à demanda de necessidade de leitura pelos escolares. Foi nesse período também que, segundo Lajolo e Zilberman (1984), ocorreu a profissionalização do escritor e editor de livros de literatura infantil, momento marcado pela "[...] produção intensa e fabricação em série, respondendo de modo ati- 
vo à exigências crescentes do mercado consumidor em expansão" (p. 86). De acordo com essas autoras, os temas e espaços idealizados nos livros para crianças desse período eram sobretudo rurais, ao passo que a vida urbana foi ignorada. Assim, embora a produção de literatura infantil fosse quantitativamente maior, explorava "[...] filóes conhecidos e evitando a pesquisa renovada" (Idem, p. 87).

Esse padrão de temas e espaços mencionados pelas autoras também pode ser observado no livro Estória do galo e do Candim$b a$, de Leonardo Arroyo (I96I), pois a maior parte dos contos se passa no ambiente rural e na floresta. Até a década de 1960, as tematizaçôes que consolidaram o terceiro ciclo da literatura infantil brasileira foram a projeção de uma criança ideal, "[...] pautada pelas expectativas do adulto [...]" (Idem, p. I20). Diante disso, nos livros infantis, evidenciou-se a dependência da criança em relação aos mais velhos, "[...] a quem os mais frágeis devem se submeter para seu próprio bem" (Idem, p. I20).

No final da década de 1960, contudo, tem início, no Brasil, uma produção de vertente mais crítica e, com ela, tem-se a abertura de um novo ciclo na história de nossa literatura infantil. Nessa nova produção literária, é possível observar a inversão dos conteúdos típicos mencionados, por meio de uma tendência contestadora. Agora, as narrativas "[...] tematizam pobreza, miséria, injustiça, marginalidade [...]", autoritarismo, preconceito, entre outros (Idem, p. I40). Além disso, é possível observar uma mudança nos enredos e nas personagens, pois "[...] deixaram de ser exemplares do ponto de vista dos valores dominantes [...]” (Idem, p. I53).

Observa-se, portanto, que a década de 1960 trouxe várias mudanças de paradigma para a história da literatura infantil brasileira, pois, segundo Perrotti (1986), a produção nessa área sofreu uma "crise" que desencadeou uma nova tendência. Até 1960, Perrotti (I986) considera que tivemos o predomínio de um discur- 
so "utilitário" nos livros infantis e que, desse período em diante, teve início uma "[...] nova tendência discursiva dirigida a grupos infantis e juvenis no país [...]” (p. II), à qual denomina primado da estética. Surgem, então, escritores com uma "[...] consciência nova de seu papel social: reclamam a condição de artistas e desejam que suas obras sejam compreendidas enquanto objeto estético, abandonando, assim, o papel de moralistas ou 'pedagogos"” (Idem, ibidem).

Acreditamos que essa transposição de concepçôes em nossa literatura infantil pode ser observada nos contos do livro proposto, principalmente no plano do enredo, dos personagens e do conteúdo que se quer transmitir. Nele, observam-se diferentes concepções de literatura infantil, bem como sua relação com a época em que foi produzido.

Assim, com esta análise, buscamos compreender os seguintes aspectos: quais são as características da produção de literatura infantil de Leonardo Arroyo? O que mudou na literatura infantojuvenil das décadas de 1960 e 1970 em diante? Quais tendências se consolidaram? E quais delas foram historicamente abandonadas?

Para tal análise, recorremos aos conceito de "configuração textual", ${ }^{2}$ proposto por Mortatti (2000, p. 3I), que consiste em enfocar

[...] o conjunto de aspectos constitutivos de determinado texto, os quais se referem: às opções temático-conteudísticas (o quê?) e estruturais formais (como?), projetadas por um determinado sujeito (quem?), que se apresenta como autor de um discurso produzido de determinado ponto de vista e lugar social (de onde?) e momento histórico (quando?), movido por certas necessidades (por quê?) e propósitos (para quê), visando a determinado efeito

2 Para maiores informaçóes sobre o conceito de análise da configuração textual, ver Magnani (1997) e Mortatti (2000). 
em determinado tipo de leitor (para quem?) e logrando determinado tipo de circulação, utilização e repercussão.

\section{I Leonardo Arroyo: aspectos da formaçáo e da atuaçáo profissional}

O jornalista, escritor e historiador Leonardo Arroyo é neto de portugueses. Seus avós maternos vieram de Portugal entre i9io e I9II, fixando residência na cidade de Caieiras (SP). Arroyo nasceu na cidade de Sáo José do Rio Preto (SP), em 26 de fevereiro de I9I8, cidade na qual viveu boa parte de seu período escolar.

Entre 1938 e I940, concluiu o curso ginasial na cidade de Santos (SP) e, aos I8 anos, iniciou a carreira de jornalista no jornal $A$ Notícia, da cidade de São José do Rio Preto (SP). Entre os anos de I938 e I940, residiu na cidade de Santos (SP) e trabalhou no jornal A Tribuna, dessa cidade (Sant'ana, 2002, p. 27). Ainda nesse período, colaborou como redator da seção "Suplemento Literário" dos jornais A Tribuna (Santos, SP), Planalto (SP) e Gazeta Magazine (SP).

Em 1940, ingressou na Faculdade de Direito da Universidade de São Paulo, mas abandonou-a no segundo ano do curso para se dedicar ao jornalismo. Em 1942, passou a contribuir para a seção "Vida literária" dos jornais Folha da Manhã e Folha da Noite, antigos nomes da Folha de S. Paulo, permanecendo nesse periódico por mais de trinta anos.

Em virtude de seu prestígio social como escritor e jornalista no país, recebeu diversos prêmios e títulos, assumindo também alguns cargos no município de São Paulo (SP). Além de sua atuação como jornalista, Arroyo é autor de diversos livros de literatura, de literatura infantil, de abordagem histórica e de história e crítica literária. 
Leonardo Arroyo faleceu em I3 de agosto de 1985, aos 67 anos, no Hospital Sírio-Libanês, na cidade de São Paulo (SP), em decorrência de derrame cerebral e pneumonia.

\subsection{Apresentaçáo do livro 3}

Conforme mencionado, o livro em questáo foi publicado na Coleçáo "Verdes Anos", apresentada como "[...] narrativas que distraem e estimulam a inteligência das crianças através das peripécias de Pedro Malasartes, João Sabido, e de animais espertos, consagrados nas estórias ${ }^{4}$ de nosso folclore" (Melhoramentos, 1965, s.p.).

$\mathrm{Na}$ segunda orelha do livro, os contos são apresentados pela editora da seguinte maneira:

Êstes, pequenos amiguinhos, são exêmplos de desobediência e das graves conseqüências que ela gera. Espero, sinceramente, que nenhum de vocês corra tantos perigos para aprender a não desobedecer e não ser teimoso. Cuidado, que sempre o castigo espera os menininhos marotos que fazem má-criação e desobedecem (Melhoramentos, 1965 , s.p.).

O livro tem formato de $20,5 \mathrm{~cm} \times 17 \mathrm{~cm}$, contém 82 páginas e sete contos: "História do Galo"; "Didi, o mosquito"; "Dom Carretel e Dona Linha"; "O Ratinho teimoso"; "Candimba, a onça e a girafa"; "O poço vigiado"; e "A sabedoria do Candimba". De acordo com Coelho (2006), o "[...] termo 'Candimba' é de origem africana e significa 'coelho' [...]” (p. 417).

\footnotetext{
3 Não tivemos acesso à primeira edição desse livro, por isso os fragmentos aqui citados foram extraídos da terceira edição, publicada em 1965 .

4 Por se tratar de uma pesquisa histórica, mantivemos a ortografia original dos textos.
} 
Impressa em papel resistente e bastante colorida, a capa contém a ilustração dos principais personagens dos contos: uma girafa na lateral esquerda, um galo ao fundo, posicionado na lateral direita, e o coelho Candimba montado em uma onça. No centro da capa, consta o título em letras bastante destacadas. Essas ilustraçôes são de J. G. Villin e, no interior, constam, em média, duas ilustraçóes por conto nas cores preto e branco. Os quatro primeiros contos, "História do Galo", "Didi, o mosquito", "Dom Carretel e Dona Linha" e "O Ratinho teimoso", já haviam sido publicados em outro livro de literatura infantil de autoria de Arroyo, intitulado Histórias do galo (I950).5

Consideramos, portanto, que Estórias do galo e do Candimba é uma versão ampliada do outro livro, com a inserção de três novos contos que, segundo Coelho (2006), foram inspirados no folclore africano, recolhidos em uma comunidade rural no interior do estado do Maranhão pelo Professor Otávio da Costa Eduardo.

A obra teve quatro ediçóes diferentes, todas publicadas pela Melhoramentos (SP): a primeira em I96I; a terceira em 1965; e a quarta em 197I. Até o momento, não localizamos informaçóes acerca do ano em que a segunda ediçáo foi publicada, nem foi possível recuperarmos exemplares de qualquer uma das ediçóes mencionadas. $\mathrm{O}$ acesso ao exemplar da terceira edição, ora apresentado neste texto, foi obtido mediante consulta ao acervo da coleção de obras raras da Biblioteca Mário de Andrade, na cidade de São Paulo.

5 Para maiores informaçóes sobre o livro, ver artigo nosso intitulado "História do galo (I950), de Leonardo Arroyo, e um modelo de formação de leitor”, publicado na revista Interfaces da Educação (2015). 


\subsection{Aspectos do conteúdo}

Há um intervalo de II anos entre a produção escrita dos quatro primeiros contos, publicados no livro História do galo, em I950, e dos três últimos, que são inéditos. Esse intervalo gerou algumas mudanças no estilo de escrita de Arroyo, nas características dos personagens e no conteúdo dos contos. Assim, para se observarem essas mudanças, os contos sáo apresentados em dois conjuntos, respeitando-se esse intervalo. O primeiro conjunto é composto por "História do galo", "Didi, o mosquito", "Dom Carretel e Dona Linha" e "O Ratinho teimoso". O segundo conjunto, por sua vez, reúne: "Candimba, a onça e a girafa", "O poço vigiado" e "A sabedoria do Candimba".

O conto "História do galo" se passa no "país do galinheiro", onde galinhas, galos, patos e marrecos viviam satisfeitos. Os personagens principais são o Galo, a Franguinha Branca, o Marreco Preto e um homem e uma mulher que visitavam o galinheiro algumas vezes ao dia. A única interrupção na rotina do galinheiro era quando, de tempos em tempos, a mulher dizia ao homem a seguinte frase: "Aquela está boa". Após dizer isso, "alguém desaparecia" (Arroyo, 1965, p. 8).

Os animais eram conformados com essa rotina, até a chegada de um galo diferente no galinheiro, que, embora bem recebido pelos outros animais, comportava-se de modo "egoísta" e "arruaceiro":

Ao ver o milho espalhado por todos os lados o novo habitante entendeu que tudo deveria ser somente seu. Começou a distribuir bicadas a torto e a direito, gritando: - Saiam todos! Deixem-me comer sossegado! [...] — Quem ousa protestar? Quero saber para dar-lhe uma lição! (Arroyo, I965, p. I0). 
Devido a esse comportamento do novato, os demais habitantes do galinheiro reuniram-se em assembleia, e Marreco Preto teve uma ideia para deixar o Galo irritado a ponto de chamar a atenção dos humanos e "desaparecer" também. Desde esse dia, a paz voltou a reinar no galinheiro: "[...] os habitantes se respeitavam, todo mundo comia em paz, sem brigas, sem algazarra” (Arroyo, 1965, p. I8).

No segundo conto, "Didi, o mosquito", a história se passa no "país da cavalariça". Os personagens principais são Didi, Dom Mosquito, Dona Mosquito (pais de Didi) e um mosquito velho e "estrangeiro" que aparecera por lá. Didi era um mosquito teimoso, barulhento, um "diabinho em pessoa", que não ouvia os conselhos dos pais nem ia à escola: "Dona Mosquito ralhava com êle, Dom Mosquito vivia a dar-lhe bons conselhos, mas o travêsso não levava a sério o que êle dizia" (idem, p. I9). Certo dia, Didi encontrou o mosquito velho e "estrangeiro", que estava de passagem e seguia para o "país das casas". Didi, então, decidiu fugir com ele para esse novo lugar. Ao chegar lá, contudo, Didi desobedeceu ao mosquito velho, ao picar o nariz de um homem que dormia. Ao acordar, o homem encheu a casa de inseticida, Didi ficou "tonto" e quase foi apanhado. Entáo, com medo e saudade de casa, pediu ao mosquito velho que o levasse de volta para o "país da cavalariça". Didi arrependeu-se e desde "[...] êsse dia foi-se transformando. Tornou-se, afinal, obediente e ia à escola todos os dias. Ninguém mais o vira fazer travessuras" (Idem, p. 33).

No terceiro conto, "Dom Carretel e Dona Linha", a história se passa no "país do cêsto de costura" e os personagens principais são Dom Carretel, Dona Linha, tia Zefa e Dom Botão Preto, "filósofo" do país. Dom Carretel era orgulhoso, soberbo e vaidoso, enquanto Dona Linha era elegante, muito branca e sentia-se triste com os desaforos de Dom Carretel, que vivia reclamando por ter de "carregar" Dona Linha para todo canto. 
Dom Carretel não aceitava o "destino" de carregar Dona Linha, pois queria "liberdade". Após um dia inteiro de trabalho, tia Zefa deixou Dom Carretel em cima de uma cadeira, ele escorregou e saiu rolando pela sala de modo desgovernado, até se desvencilhar totalmente de Dona Linha. Dom Carretel, então, sentiu-se com muito medo e sozinho. Assim, somente após ter sido encontrado por tia Zefa e enrolado novamente em Dona Linha, voltou a se sentir bem: "Desde êsse dia, Dom Carretel vive em paz no país do cêsto de costura. E gosta muito de Dona Linha [...]" (idem, p. 40).

No quarto e último conto desse conjunto, "O ratinho teimoso", a história se passa na despensa da cozinha de um "velho casal". As personagens principais são Dom Rato, Dona Rata, Ratinho e o Gato Amarelo. Dom Rato era muito cauteloso e experiente, e "[...] não permitia estragos no país da despensa. Não deixava que Dona Rata e Ratinho roessem os sacos de mantimentos apenas pelo prazer de destruir nem que se atirassem às lingüiças e aos queijos de ralar, por esganaçáo" (Idem, p. 4I).

Ratinho, por sua vez, era desobediente, teimoso e esganado, e vivia visitando o local às escondidas. A chegada de um novo queijo deixou Ratinho com muita fome e com vontade de desobedecer. Um dia, enquanto seus pais dormiam, Ratinho foi até a despensa e começou a roer o queijo. E roeu tanto que fez um buraco no queijo e decidiu dormir lá dentro. Quando acordou, foi surpreendido pelo Gato Amarelo. Depois de sentir muito medo, Ratinho aproveitou um minuto de sono do Gato Amarelo para escapar e voltar para casa. Desse dia em diante, nunca mais desobedeceu.

No segundo conjunto de contos inéditos, constam: "Candimba, a onça e a girafa", "O poço vigiado" e "A sabedoria do Candimba”. 
No primeiro conto, Candimba quer se casar com a dona Girafa, mas ela já estava de casamento marcado com o camarada Onça. Candimba, então, se irrita e diz que dona Girafa estava fazendo uma péssima escolha, pois a camarada Onça era o seu "cavalo". Dona Girafa não acreditou naquela conversa e logo dispensou Candimba. No entanto, no dia do casamento, "[...] o coelho pegou a sua sela, a manta, as esporas e os estribos, e escolheu um lugar perto da estrada que levava à casa da dona Girafa" (Idem, p. 56). Sentou-se perto de onde todos passariam, mas disse que não iria ao casamento, pois estava com dor dente. Quando o noivo passou por ali, contou-lhe essa história e, com pena do coelho, o noivo ofereceu-lhe uma carona em seu lombo.

- Oh! o camarada Onça é muito gentil! Mas eu não posso ir ao casamento e deixar a minha manta aqui na estrada.

- Ôra Candimba, eu faço questão que você vá, bote a manta aqui em cima de mim. [...]

- Assim eu caio, choramingou o coelho, preciso amarrar a manta e colocar a sela. Ai, ai, meu dente (Arroyo, 1965, p. 57).

Assim, enganando o camarada Onça com seu discurso de doente, Candimba conseguiu convencê-lo a vestir todos os itens da montaria, aparecendo no casamento com seu "cavalo", como havia afirmado à dona Girafa. Após esse episódio, dona Girafa desiste do casamento e pede vingança. $\mathrm{O}$ camarada Onça procura um jeito de "pegar" Candimba. Então, Dom Jabuti chega com a informação de que Candimba vinha, toda noite, até a beira do rio para tomar água. A pedido do camarada Onça, Dom Jabuti cobre-se de cera e esconde-se perto de um monte de pedras. Assim, ao tocar "naquele vulto", Candimba fica preso e é pego pelo Onça. Candimba, então, pede desculpas, mas engana o camarada Onça mais uma vez, dizen- 
do que tinha uma recompensa maior: um boi bem gordo no pasto. Ao "buscar" a recompensa, o coelho foge sem deixar vestígio.

O segundo conto, "O poço vigiado", narra a história de um poço construído pelos animais da floresta para evitar a longa distância diária até o rio. Candimba foi o único entre os animais que não ajudou em sua construçáo, porque dizia estar com dor de dente. Diante disso, todos decidiram que Candimba não tomaria a água do poço. Mas, mesmo assim, todo dia à noite, Candimba enchia suas caçapas com água sem que ninguém o visse. Após muitas tentativas de outros animais em desmascará-lo, o camarada Onça consegue flagrá-lo e contrata o compadre Urubu para vigiá-lo. No entanto, Candimba também o engana, jogando areia em seus olhos e fugindo mais uma vez.

No último conto, "A sabedoria de Candimba", o coelho decide construir uma "tapagem" à beira do rio para pescar peixes. O camarada Onça, por sua vez, não conseguia pegá-los e estava com fome, então decidiu perguntar a Candimba como ele fazia. O coelho mostrou orgulhosamente sua construção, e o camarada Onça decidiu tirar vantagem da situação por meio de sua força. Tomou para si a construção, ficando com os peixes maiores e entregando os menores a Candimba. Um dia, Candimba teve uma ideia: correu para dentro da mata e começou a gritar, dizendo que precisava amarrar-se às árvores porque uma forte tempestade se aproximava. Assustado com os gritos do coelho, o camarada Onça pediu para ser amarrado primeiro. Após três dias, foi solto pelo mestre Macaco e escondeu-se na casa de Candimba, a fim de pegá-lo. Candimba, no entanto, voltou a enganá-lo e se salvou.

Em todos os contos, as ilustraçóes apresentam um caráter elucidativo e/ou referencial, ilustrando o poder de verdade da fantasia no texto literário. Atuam, portanto, como uma síntese do texto escrito, e não como uma extensão da leitura. 


\subsection{Personagens}

O coelho Candimba é o único personagem que transita entre os contos, fazendo-se presente em três do total de sete. Por isso, é possível observar um padráo de continuidade entre alguns contos, visto que as histórias se passam no mesmo ambiente - a floresta e na companhia e/ou no confronto dos mesmos animais. Curioso, nesse aspecto, é o fato de o personagem Galo aparecer apenas no conto intitulado "Histórias do Galo", já que também compóe o título do livro.

Outro aspecto digno de nota em relação aos personagens é que são todos animais e, assim como nas fábulas, apresentam características humanas, como sentimentos e comportamentos inteligíveis. A única exceção a esse padrão é o conto "Dom Carretel e Dona Linha”, em que os personagens são objetos.

No primeiro conjunto de contos, a maior parte dos personagens centrais está em idade infantil, portanto assemelha-se às crianças. Essa condiçáo é marcada por atitudes como mostrar-se egoísta, manifestar gula e teimosia, ser desobediente, não querer ir à escola, entre outras. De modo geral, os personagens infantis desobedecem a uma orientação dos mais velhos e são "castigados". Em seguida, arrependem-se e readquirem o equilíbrio. $\mathrm{O}$ estado final ${ }^{6}$ desses contos é apresentado, portanto, com a correção que vem dos personagens adultos ou com o pedido de desculpas dos personagens infantis. Assim, comportamentos como ser obediente, saber viver em comunidade, compartilhar o alimento sem desperdício, não demonstrar gula, sentir gratidão, não ter preguiça e não se arriscar são atitudes valorizadas na criança que aprende a lição no final dos contos. Nesse contexto, os animais em idade

6 Segundo Yves Reuter (2002), trata-se do modelo de narrativa composto por cinco estados de transformação: estado inicial; complicação ou força perturbadora; dinâmica; resolução ou força equilibradora; e estado final. 
infantil legitimam a imagem da criança em fase de desenvolvimento, que necessita da orientaçáo dos adultos. A literatura infantil, portanto, cumpre seu papel de "instrumento de educaçáo" (Lourenço Filho, 1943), como apregoado entre os livros publicados naquele período.

Nos quatros primeiros contos, os modelos narrativos se organizam numa sequência de eventos que se desenrolam em busca de um equilíbrio final para o desequilíbrio provocado. Desse modo, a narrativa centra-se na ação que busca a resolução do problema e na "lição" que pretende transmitir.

Em oposição a essa dinâmica, estão os três últimos contos, nos quais Candimba é o personagem principal: "Candimba, a onça e a girafa", "O poço vigiado" e "A sabedoria de Candimba". Nesses casos, a mensagem ou o instrumento de educação são outros: a esperteza e a inteligência, com frequência associadas à capacidade de enganar e de tirar vantagem do outro. Esses aspectos podem ser observados, principalmente, nos dois primeiros contos desse conjunto.

No segundo conjunto, não há diferenciação entre as idades dos personagens, portanto não há personagens adultos sustentando as açôes das crianças, ora para castigá-las, ora para auxiliá-las a sair de algum problema. Neles, o estado final não visa ao retorno do equilíbrio que havia no estado inicial, visto que o objetivo é que Candimba saia "ileso" às situaçóes de conflito provocadas, por ele mesmo, no início da narrativa. Desse modo, o equilíbrio ou a resolução do conflito decorrem de um desfecho inusitado, em geral representado pela "fuga" ou o "escape" da situação, conforme se observa nos seguintes fragmentos: 
Conto "Candimba, a onça e a girafa":

- Então, vá buscar o boi que eu espero aqui junto com o Jabuti. Candimba saltou e foi embora. O camarada Onça, conversando com o dom Jabuti, até hoje está esperando pelo esperto coelho. Está claro que Candimba não voltou com boi nenhum! (Arroyo, I965, p. 63).

Conto "O poço vigiado":

E levantou a voz pela terceira vez:

- Eh, minha casa!

E o camarada Onça escondido perto da porta (ai, que tonto o camarada Onça) respondeu numa voz grossa:

- U...U...U...

Candimba deu uma gargalhada enorme.

— Essa é boa! Onde se viu casa falar?

E correu para longe, a tôda velocidade! (idem, p. 82)

Outro aspecto da dinâmica desse conjunto de contos é que a trama se desenvolve até que Candimba consiga realizar o que disse no início da narrativa:

- Olha lá dona Girafa. Você recusou casar comigo, mas vai casar com meu cavalo!

- O que você disse Candimba? [...]

— Então não sabe? [...]

- Pois eu virei ao casamento montado no camarada Onça, que é meu cavalo! (Arroyo, 1965, p. 55)

O conto "A sabedoria de Candimba" é o único desse conjunto em que a esperteza do coelho é utilizada para livrá-lo de uma situação não provocada por ele. Sua inteligência o ajudou a sair 
de um conflito em que estava sendo explorado pelo "camarada Onça".

— [camarada Onça] Quem vai dividir os peixes de hoje em diante sou eu! [...]

O coelho ficou amedrontado, mas, no íntimo, jurou vingar-se do camarada Onça na primeira oportunidade (Arroyo, 1965, p. 74).

A narração se assemelha à tradição oral. Esse recurso garante uma linguagem que prende a atenção do leitor, pois intercala a narração com os diálogos entre os contadores e os ouvintes das histórias. Em todos os contos, o narrador é um observador objetivo, não conhece o que se passa na mente dos personagens e apenas relata os fatos, por meio da descrição, da ação dos personagens e dos diálogos (Reuter, 2002).

\subsection{Espaço e tempo}

A representação dos espaços é feita por ambientes comuns à literatura infantil, os quais lembram ambientes rurais, tais como: floresta, galinheiro, cesto de costura, estábulo de cavalos e despensa de uma cozinha. Esses ambientes conferem verossimilhança às histórias e permitem ao leitor identificar-se com o espaço representado.

As narrativas se passam em curtos espaços de tempo, configurando os eventos numa sequência cronológica e linear. Desse modo, não há complexidade no encadeamento das ações, podendo ser mensuradas por meio da alternância de dias e noites. 


\subsection{Momento histórico de produçáo}

Os anos I950, em linhas gerais, fomentaram o início de um processo de industrialização nacional, promovida pela abertura ao capital externo para investimento. Essa influência estrangeira decorreu principalmente do alinhamento político que o Brasil adotou junto a Inglaterra, França, Estados Unidos e Uniāo Soviética, contra os regimes nazifacistas da Alemanha, da Itália e do Japão (Lajolo e Zilberman, I986).

A década de 1960 foi um momento cultural eminentemente crítico e polêmico, com o endurecimento do regime a partir de 1964. A literatura para crianças e jovens não permaneceu imune às transformaçóes ocorridas na sociedade brasileira, e a produção de textos literários provocou a formação de novos padróes de desenvolvimento, com personagens mais críticos. Observam-se mudanças significativas nos sete contos que integram Estória do galo e do Candimba, principalmente quanto às características dos personagens e ao conteúdo das histórias.

Os primeiros quatro contos, publicados inicialmente em I950, apresentavam-se ligados à tradição que se instalara no gênero, articulando-se com as concepçóes educacionais, editoriais e psicológicas do período, que, de acordo com Lajolo e Zilberman (I986), valorizavam a produção de modelos de comportamento nas histórias infantis: "[...] atitudes ideais e crianças exemplares" (p. I29). E acrescentam:

[...] os autores dos anos 40 e 50 amansam o comportamento dos protagonistas, agora mais domésticos e dependentes, preocupados em demonstrar sua correçáo perante os adultos [...]. As crianças passam por várias aventuras, geralmente seguidas de sentimentos de culpa [...] (Idem, pp. I30-I). 
Seguindo essa tendência de produção literária, a criança leitora, para Arroyo, era considerada pela ótica da psicologia e da educação, o que acabava por limitar as opçôes literárias e estéticas. Assim, no livro em questáo, os aspectos desse projeto de educação são concretizados, e a formação pretendida se aproxima da transmissão de normas, realçando a égide familiar, o bom comportamento, o ensino e o trabalho.

Nos três últimos contos, todavia, há uma mudança de paradigma em relação aos demais apresentados, pois Candimba assume uma tendência contestadora e irreverente na literatura infantil, táo diferente dos demais, o que gera certa estranheza e reaçóes polêmicas do ponto de vista social. Com o personagem Candimba, sobressai-se a ideia de fazer da leitura de literatura infantil um elemento de formação estética, e não de difusão de civismo e patriotismo, de linguagem modelar e de ensino. Assim como Arroyo, muitos autores e obras passaram a representar "[...] a criança capaz de rebeldia e de ruptura com a normatizaçáo do mundo dos adultos. Enfraquece, assim, a velha prática de representar nos livros infantojuvenis apenas situaçóes não problemáticas" (Luft, 20IO, p. II3).

Perrotti (1986), contudo, afirma que o desejo de renovação resultou, em muitos casos, num conjunto de obras "equivocadas", reunidas sob o título "o utilitarismo às avessas" (p. 23), pois, embora fossem renovadas pelo fato de acolherem o ponto de vista da criança e não mais do adulto, sua dinâmica procurava impor um novo comportamento ao leitor. Esse fato criava novamente outro "[...] modelo de criança ideal [...]", o qual deveria ser seguido (idem, p. I23). No livro de Arroyo, as mudanças na concepção de literatura infantil saltam aos olhos ao se levar em conta o intervalo de II anos da publicação de um conjunto de contos para o outro.

É possível observar que esse esforço de renovação em Estória do galo e do Candimba também levou ao "utilitarismo às avessas" 
diagnosticado por Perrotti. De um lado, os personagens infantis são representados como aqueles que "erram" sempre e precisam hierarquicamente aprender a "lição" com os adultos. De outro lado, o personagem Candimba pode fazer tudo o que quiser, pois o importante é que sua vontade seja satisfeita. Desse modo, os contos desse livro apresentam oposiçóes drásticas entre si, quebrando o encadeamento e o equilíbrio, pois os campos estáo muito polarizados: nada posso sozinho (sem a companhia do adulto) versus tudo posso (pois somente a minha vontade importa).

Perrotti (1986) indaga: seriam os "[...] critérios estéticos suficientes para a apreensão do problema? Se forem, há ainda uma questáo que fica no ar: que estética? [...]" (p. 20). Reconhecer as reais tendências da literatura para crianças e jovens, bem como os modismos de determinada época, não é tarefa fácil, principalmente quando a cultura e a obra de arte tornaram-se comprometidas com o mercado.

Em Estória do galo e do Candimba (196I), as diferentes concepçôes de literatura infantil evidenciam o momento de "crise" de uma época e as mudanças que se consolidaram nas décadas de I960 e 1970 em diante. Não se pode perder de vista, ainda, que o valor de uma obra literária oscila com o tempo, dependendo dos sujeitos - autorizados - que a julgam. Assim, os sujeitos e as instituiçôes envolvidas na "cadeia produtiva" da literatura infantil - representada por autores, editoras, educadores, pesquisadores e o leitor previsto - interferem nas concepçóes de "boa literatura" que o gênero vem assumindo historicamente (Mortatti, 2008).

\section{Consideraçóes finais}

Por meio do livro analisado, é possível compreender aspectos importantes da produção de literatura infantil de Leonardo Arroyo, em consonância com as concepçóes desse gênero literário 
após meados do século XX no Brasil. Também foi possível compreender alguns aspectos de sua atuação profissional, pois, como escritor para crianças, contribuiu para a literatura infantil com esse livro, que teve quatro ediçóes em um período de II anos.

A análise histórica de Estória do galo e do Candimba permite-nos olhar do ponto de vista do presente, reconhecendo os lugares de origem de nossa literatura infantil, bem como compreendendo as relaçóes de cultura e poder que a mediaram e permanecem até os dias atuais.

Esse livro, portanto, sintetiza as contradiçôes entre a continuidade de uma tradição e o desejo de renovação cultural na infância brasileira. Trata-se de uma obra que permaneceu no tempo, impulsionada, talvez, por suas próprias contradiçóes e pelas contradiçóes de sua época, formando diferentes leitores, reescrevendo as “dobras" da literatura para a infância e para uma educação literária em nosso país.

\section{Referências}

ARROYO, Leonardo. Estória do galo e do Candimba. ed. São Paulo: Melhoramentos, I965.

DONATO, Hernâni. Ioo anos de Melhoramentos: I890-1990. São Paulo: Melhoramentos, 1990 .

LAJOLO, Marisa e ZILBERMAN, Regina. Literatura infantil brasileira: história \& histórias. São Paulo: Ática, 1984.

. Um Brasil para crianças: para conhecer a literatura infantil brasileira: história, autores e texto. São Paulo: Global, 1986.

LOURENÇO FILHO, Manuel Bergstrom. "Como aperfeiçoar a literatura infantil”. Revista Brasileira, Rio de Janeiro, v. 3, n. 7, pp. I46-69, 1943.

LUFT, Gabriela. "A literatura juvenil brasileira no início do século XXI: autores, obras e tendências". Estudos de Literatura Brasileira Contemporânea, n. 36. Brasília, jul./dez. 20IO, pp. III-30. 
MORTATTI, Maria do Rosário Longo. Os sentidos da alfabetização (São Paulo, I876-I994). São Paulo: Unesp; Brasília: Mec/Inep/Comped, 2000. . "Literatura infantil e/ou juvenil: a 'prima pobre' da pesquisa em Letras?". Revista Guavira Letras, Três Lagoas, n. 6, pp. 43-52, 3I mar. 2008.

PERROTTI, Edmir. O texto sedutor na literatura infantil. São Paulo: Ícone, 1986.

REUTER, Yves. A análise da narrativa: o texto, a ficção e a narração. Trad. Mario Pontes. Rio de Janeiro: Difel, 2002. 


\section{6 \\ "Literatura em minha casa": a seleção de livros para crianças ${ }^{1}$}

Célia Regina Delácio Fernandes

Flávia Ferreira de Paula

\section{I Literatura: nutriçáo do intelecto e da sensibilidade}

A literatura não é, como tantos supõem, um passatempo. É uma nutrição.

Cecília Meireles

A formação do leitor é complexa e envolve muitos fatores. Entre as instituiçôes envolvidas nesse processo, destaca-se a importância da escola, tendo em vista que é o local em que a maioria dos alunos tem seu primeiro contato com a leitura. $\mathrm{O}$ espaço para leitura se restringe, em boa parte, ao ambiente escolar, já que a quantidade de bibliotecas públicas e de fácil acesso é pequena. Além disso, os meios de comunicação em massa, em especial televisão, jogos virtuais e internet, ocupam boa parte do tempo livre das crianças e jovens. Assim, para que a leitura seja uma atividade agradável desde a infância, a escola precisa promover uma aproximaçáo entre crianças e livros. E essa aproximação demanda material de qualidade e biblioteca, além de profissionais qualificados, metodologia e planejamento. Azevedo (200I) esclarece que "textos didáticos são essenciais para a formação das pessoas, mas não formam leitores. É preciso que

I Este texto foi publicado na revista Teias, v. I6, n. 4I, 20I5, e atualizado para este livro. 
concomitantemente haja acesso à leitura de ficção, ao discurso poético, à leitura prazerosa e emotiva, para que isso aconteça (p. 3)".

Nessa perspectiva, a literatura infantojuvenil desempenha, nas séries iniciais, papel essencial na formação de novos leitores, porque as crianças gostam de imaginar, criar histórias e entrar no mundo da fantasia. Como bem aponta Lajolo (2005): "Para começar, a escola precisa de livros. Muitos e bons" (p. I4) e também precisa incentivar o uso da biblioteca, criar salas de leitura.

Em entrevista concedida a Nascimento (2003, p. 52), Marisa Lajolo destaca que "a relação entre literatura infantil, literatura juvenil e escola vem desde o nascimento desses gêneros e está cada vez mais entrelaçada”. Grande parte dos livros produzidos pelas editoras é comprada pelo governo e enviada às escolas públicas. Para isso, acontece uma seleção criteriosa. É fundamental, nesse cenário de compras de acervos a serem enviados às escolas, levantar dados referentes às políticas públicas de leitura e aos programas governamentais de incentivo à leitura escolar no Brasil, assim como mapear e analisar os critérios levados em consideraçáo pelas instâncias governamentais na escolha dessas obras literárias.

Dada a importância de se analisar o que vem sendo apontado como literatura de "boa qualidade" ${ }^{2}$ na seleção das obras para as compras governamentais nos últimos anos, este capítulo é o resultado de um estudo do projeto "Literatura em minha casa", do Programa Nacional Biblioteca da Escola (PNBE), nos anos de 2001, 2002 e 2003, em especial as obras destinadas às quarta e quinta séries ${ }^{3}$ do ensino fundamental, somando um total de I2O.

\footnotetext{
2 Não se pretendeu, aqui, discutir o que é literatura boa ou ruim, mas tão somente fazer um estudo sobre alguns aspectos das obras escolhidas para os acervos em questáo, ou seja, as obras consideradas "boas" pelo Programa Nacional Biblioteca da Escola (PNBE) nos anos de 200I, 2002 e 2003. 3 As nomenclaturas se referem às séries da época do projeto, que correspondem, hoje, aos quinto e sexto anos do ensino fundamental.
} 
Com base na hipótese de Fernandes (2007) de que existem autores e obras consagrados pela crítica que formam um cânone literário infantojuvenil, em detrimento do critério de diversidade estabelecido nos editais de convocação para a inscrição de coleçôes de obras do PNBE (Brasil, 200I; 2002; 2003), procuramos analisar os critérios de seleçáo para as compras, as repetiçóes de obras nos acervos, os autores e ilustradores mais recorrentes, bem como identificar as editoras contempladas, as temáticas mais frequentes, a pluralidade cultural presente nos livros e ainda eventuais imagens de regionalismo e do regional do Mato Grosso do Sul no cânone literário infantojuvenil nos anos em foco.

A relevância acadêmica desta pesquisa se deve não somente à importância das políticas públicas de compra e distribuiçáo de livros para a formação de leitores na sociedade, como também ao desconhecimento de grande parte da população sobre o Programa Nacional Biblioteca da Escola (PNBE) e sobre o projeto "Literatura em minha casa" (Paula, 20IO; Paula e Fernandes, 20IO; 2016). Além disso, o tema regionalismo na literatura infantojuvenil é uma novidade, já que não foram encontradas pesquisas nessa área. Também levamos em consideração a importância social de se buscarem representaçóes de pluralidade cultural nas obras um dos temas transversais dos Parâmetros Curriculares Nacionais (Brasil, 1998) - que digam respeito à valorização de características étnicas e culturais de diferentes grupos sociais que convivem no território nacional.

\subsection{O projeto "Literatura em minha casa"}

Chegando em casa, não comecei a ler. Fingia que não o tinha só para depois ter o susto de o ter. Horas depois abri-o, li algumas linhas maravilhosas, fechei-o de novo, fui passear pela casa, adiei ainda mais indo comer pão com manteiga, fingi que náo sabia onde 
guardara o livro, achava-o, abria-o por alguns instantes. Criava as mais falsas dificuldades para aquela coisa clandestina que era a felicidade. $[\ldots]$

Clarice Lispector

Criado em 1997, sob a gestão do Fundo Nacional de Desenvolvimento da Educação (FNDE), o Programa Nacional Biblioteca da Escola (PNBE) tem como principal objetivo apoiar o cidadáo no exercício da reflexáo, da criatividade e da crítica, por meio da distribuição de obras de literatura, pesquisa e referência.

Garantir o acesso à informação e à cultura, além de estimular a formação do leitor na escola e na comunidade, foram os elementos motivadores para a criação desse programa, que vem distribuindo livros para as escolas e a comunidade. Assim, sua finalidade consiste em viabilizar a diversidade das fontes de informação das escolas públicas brasileiras, contribuindo para o aprimoramento da consciência crítica dos alunos, professores e comunidade em geral (Paula e Fernandes, 20I4).

A partir de 200I, o Programa Nacional Biblioteca da Escola (PNBE) modificou a sistemática anterior, deixando de enviar livros às bibliotecas escolares, como nos anos anteriores, para distribuí-los diretamente aos alunos. Assim, os alunos teriam acesso direto às coleçôes, com obras representativas da literatura nacional e estrangeira, de modo que pudessem levar os livros para casa, o que favorecia a troca em casa e entre colegas. Assim, o projeto, intitulado "Literatura em minha casa", buscou incentivar os aprendizes a ler, deixando-os na condição de proprietários dos livros e, assim, permitindo também o contato de suas famílias com a leitura.

$\mathrm{Na}$ época, muitas foram as críticas à questão da posse privada dos livros em detrimento da posse pública, fazendo do livro propriedade do aluno, e não mais da comunidade escolar. É relevante, nessa perspectiva, refletir a respeito da importância de o 
aluno - leitor em formação - ter o livro em casa e como sua propriedade.

Resultados da pesquisa "Retratos da leitura no Brasil" (Instituto Pró-Livro, 2008) apontam dados importantes no que se refere ao fato de os entrevistados possuírem ou náo livros em casa e às práticas de leitura dentro de casa, entre os membros da família. Nesse contexto, entre os não leitores (quem declarou não ter livro nenhum livro nos últimos três meses), $86 \%$ revelaram nunca terem sido presenteados com livros na infância, enquanto, entre os leitores (quem declarou ter lido pelo menos um livro nos últimos três meses), esse índice caiu para $49 \%$. Além disso, entre os não leitores, $68 \%$ afirmaram que nunca ou raramente viam os pais lendo. No que se refere aos leitores, $60 \%$ declararam que viam os pais lendo sempre ou de vez em quando.

No que concerne à posse de livros no Brasil, a pesquisa mostra que I46,4 milhóes de brasileiros ( $85 \%$ da população analisada) afirmam possuir pelo menos um livro em casa, com uma média de 25 livros por residência. Observa-se que três em cada cinco livros pertencem ao entrevistado, enquanto os demais ou são de outras pessoas da família, ou são emprestados, ou ainda pertencentes a programas governamentais.

A terceira edição da pesquisa "Retratos da leitura no Brasil" (Instituto Pró-Livro, 2012) corrobora esses dados, ao mostrar que, entre os não leitores (quem declarou não ter lido nenhum livro nos últimos três meses, mesmo que tenha lido algo nos últimos I2 meses), 87\% responderam nunca terem sido presenteados com livros; por sua vez, entre os leitores (quem declarou ter lido pelo menos um livro, inteiro ou em partes, nos últimos três meses), esse índice caiu para 60\%. Registra-se ainda, nessa edição, que, entre os leitores, 93\% afirmaram costumar ler livros em casa, ao passo que I2\% declararam ler em bibliotecas. 
A edição mais recente de "Retratos da leitura no Brasil", datada de 2015 (Instituto Pró-Livro, 20I6), expóe alguns resultados melhores, ao cotejarmos com a edição de 20 II: o número de leitores aumentou, proporcionalmente, de $50 \%$ para $60 \%$. No que diz respeito à posse, $79 \%$ declararam nunca terem sido presenteados com livros; entre os leitores, contudo, esse índice caiu para 53\%. Ainda no que tange às principais formas de acesso ao livro, apesar das alterações nas opçôes de resposta, é possível compararmos o item "Distribuídos pelo governo ou pelas escolas": $15 \%$ em 20 II e $9 \%$ em 20I5. Chama a atenção essa diminuição no quesito, o que aponta para uma queda nos resultados das políticas públicas exatamente quando o PNBE estava suspenso. No entanto, essa eventual causa demandaria mais investigação.

Diante desses dados estatísticos, podemos concluir que a posse de livros é de grande importância para o leitor durante a infância, período em que ainda está adquirindo o hábito de leitura. Os livros em mãos são motivo de bastante entusiasmo para as crianças, tal como descreve a personagem de Felicidade clandestina, de Clarice Lispector (2002). Ter livros à disposição ou náo dos aprendizes, seja em casa, seja na escola, é fator determinante para a formação do leitor. Daí a relevância de se discutirem as políticas públicas de leitura, como o PNBE, e também os projetos que incentivam a leitura junto à família, como o "Literatura em minha casa", que distribuiu livros aos alunos das escolas públicas.

Com início em 200I, o projeto teve seu material de divulgação enviado às escolas na forma de folder, cujas ilustraçóes ficaram a cargo do escritor e cartunista Ziraldo. Em seu texto, o Ministério da Educação deixa claros seus objetivos: 


\section{LIVRO É GÊNERO DE PRIMEIRA NECESSIDADE.}

Livro é para levar pra casa.

É pra criança ler com a mamãe, o papai, a vovó, a família toda! É um objeto pra ser amado pela criança. Pra ela dormir abraçada, escrever seu nome nele, colorir suas figuras, usufruí-lo...

DEIXE A CRIANÇA VIVER COM O LIVRO! (MEC, folder do projeto "Literatura em minha casa")

No primeiro ano do projeto "Literatura em minha casa", foram distribuídas obras de literatura infantojuvenil aos matriculados nas quartas e quinta séries do ensino fundamental. Nesse ano, o acervo contou com trinta títulos, organizados em seis coleçóes de cinco volumes (poesia de autor brasileiro, conto, novela, clássico da literatura universal e texto de tradiçáo popular brasileira ou peça teatral). Com um total de mais de oito milhóes e quinhentos mil livros distribuídos para quase 6I milhóes alunos beneficiados, cada uma das I39.II9 mil escolas contempladas recebeu quatro acervos, com 24 coleçóes, totalizando um investimento de $\mathrm{R} \$$ 57.638.015,60.

Em 2002, o programa distribuiu novamente a coletânea "Literatura em minha casa". Compostas de cinco obras literárias (poesia de autor brasileiro, conto, novela, clássico da literatura universal e texto de tradição popular brasileira ou peça teatral), as oito coletâneas foram entregues apenas aos alunos da quarta série das escolas públicas do ensino fundamental, em virtude da redução dos recursos destinados ao programa. Um total de 21.082.880 livros distribuídos, 3.841.268 alunos beneficiados em I26.692 escolas e um investimento de $\mathrm{R} \$ 19.633 .632,00$.

Em 2003, o programa foi executado em cinco diferentes açóes: I) "Literatura em minha casa”; 2) Palavras da gente - educação de jovens e adultos; 3) Casa da Leitura; 4) Biblioteca do professor; 5) Biblioteca escolar. Nesse ano, foram I8.0IO.40I alunos contempla- 
dos, em I4I.266 escolas beneficiadas, com um total de 49.034.192 livros distribuídos e de $\mathrm{R}_{\$}$ II0.798.022,00 investidos. O acervo para a quarta série - que interessa à presente pesquisa - foi, como em 200I e 2002, composto por dez coleçóes, com cinco volumes cada.

\subsection{Critérios de seleçáo das obras}

Para que se forme um leitor de maneira democrática, as instituiçôes envolvidas precisam contar com estratégias confiáveis de avaliação, compra e distribuição. Assim, é essencial, nos estudos referentes às políticas públicas de leitura e aos programas governamentais de incentivo à leitura escolar no Brasil, que se levantem dados a respeito dos critérios considerados legítimos pelas instâncias governamentais na escolha das obras literárias que compóem os acervos do PNBE (Fernandes, 2017; Fernandes e Cordeiro, 20I2).

O edital de 200I definiu as regras para a inscrição de coleçôes de obras de literatura, incorporando quatro anexos, consistentes em partes indissolúveis. São eles: I) Especificações técnicas; II) Critérios de avaliação e seleção; III) Triagem; IV) Declaração de titularidade. Merece destaque a repetição, no acervo de 200I, de obras presentes nos acervos dos anos anteriores, tais como Bisa Bia, Bisa Bel, de Ana Maria Machado; A formiguinha e a neve, adaptada por João de Barro; Minhas memórias de Lobato, que consta como adaptação de Monteiro Lobato no PNBE/r999, embora registrada sob a autoria de Luciana Sandroni no PNBE/20oI; e $A$ arca de Noé, de Vinicius de Moraes, todas integrantes do acervo do PNBE/I999. Tais repetiçóes - que poderiam ter sido evitadas pelas editoras, caso houvesse alguma recomendação no edital -, é importante sublinhar, reforçam a canonização desses autores consagrados pela crítica (Fernandes, 2007, p. 7I). 
O edital para o $\mathrm{PNBE} / 2002$ apresentou poucas alteraçóes em relaçáo ao conteúdo e à forma do edital de 200I, com alguns pequenos acréscimos. No que diz respeito aos critérios de seleção, a principal mudança consistiu em privilegiar autores "representativos da produção literária brasileira e universal". Outro aspecto foi a exclusão das obras que compunham as coleçôes do PNBE/20or. Também foi esclarecido o que se esperava das ilustraçôes, acrescentando-se, ao final, um item sobre o projeto editorial na avaliação das coleçôes. Portanto, é possível constatar um aprimoramento em seus aspectos, com maior clareza na redação, em comparação ao edital do ano anterior. Destacamos, contudo, a repetição de obras como $A$ bolsa amarela, de Lygia Bojunga, As aventuras de Alice no pais das maravilhas, de Lewis Carroll, e A terra dos meninos pelados, de Graciliano Ramos, distribuídas pelo PNBE/1999, novamente reforçando a canonização de autores consagrados pela crítica (Fernandes, 2007, p. 73).

Em 2003, o edital apresentou poucas modificaçóes em relaçáo ao edital do ano anterior, ampliando algumas especificaçóes das coleçóes para a oitava série e a Educação de Jovens e Adultos (EJA). No que tange à seleçấo das obras, o edital manteve o critério de representatividade dos autores escolhidos como fator relevante para a escolha do acervo. Destacamos dois livros do mesmo autor e com os mesmos personagens. Trata-se de dois livros de Mark Twain: Tom Sawyer e Tom Sawyer detetive. A primeira obra, uma adaptação de Ruth Rocha, faz parte da coleçáo da Editora Objetiva, narrada em terceira pessoa. A segunda, por sua vez, adaptada por Carlos Heitor Cony, integra a coleçáo da Quinteto Editorial, narrada em primeira pessoa pelo amigo de Tom Sawyer, Huck Finn. A qualidade das obras e sua boa receptividade ao público infantojuvenil são inquestionáveis, mas a repetição atenta contra o critério da diversidade, exposto no edital. 
Os critérios de seleção para as compras nos anos em questão, conforme verificamos nos editais de convocação de obras de literatura para as coleçóes (Brasil, 200I; 2002; 2003), contaram com aspectos que, basicamente, podem ser resumidos em duas exigências: diversidade (de gêneros, assuntos, títulos e autores de diferentes épocas e regióes) e materialidade da obra (projeto gráfico e ilustraçôes que levam em consideração o público-alvo em questão, como, por exemplo, tamanho da letra e fonte).

\subsection{Editoras contempladas: o mercado editorial do projeto "Literatura em minha casa"}

Em estudo intitulado "Livros para a educação infantil: a perspectiva editorial”, Magda Soares (2008) afirma que

[...] a atividade editorial tem sido pouco contemplada como objeto de estudo nas pesquisas sobre literatura infantil, que têm se voltado sobretudo para a análise de livros, de autores, de ilustradores, para a atuação da escola e das bibliotecas na promoção e orientação da leitura infantil, para as reaçôes das crianças à leitura de literatura infantil (pp. 2I-2).

Assim, com base na ideia de que "a resposta das editoras às demandas das políticas de incentivo à leitura de crianças e jovens, políticas que vêm se ampliando nas últimas décadas, permite identificar alguns aspectos da atividade editorial na área de literatura infantil" (Idem, pp. 2I-2), buscamos esses aspectos nos acervos de 2001, 2002 e 2003 do PNBE, tanto no que tange às editoras contempladas nessas ocasiôes, com a respectiva localização, como aos autores e ilustradores mais recorrentes nas obras estudadas. 
O estudo sobre as editoras que abastecem o mercado de literatura infantojuvenil brasileira em três anos do PNBE indicou que a maioria das editoras está localizada na Região Sudeste do país (Figura 6.I), exclusivamente em São Paulo ( $48 \%$ do total) e no Rio de Janeiro (38\%). Apenas uma editora (Newtec) se situa em outra regiáo - a Regiáo Sul -, no estado do Rio Grande do Sul (4\%). Esses estados correspondem, como apontamos, respectivamente, ao primeiro, ao segundo e ao quarto PIBs mais altos do país (IBGE, 2007). Também destacamos o fato de o projeto " $\mathrm{Li}$ teratura em minha casa" haver contemplado apenas editoras grandes, já que as obras eram escolhidas apenas por coleçóes, não se tratando de obras individuais, o que levou à exclusão das editoras pequenas. Além disso, os autores consagrados, em sua maioria, pertencem às editoras de maior porte.

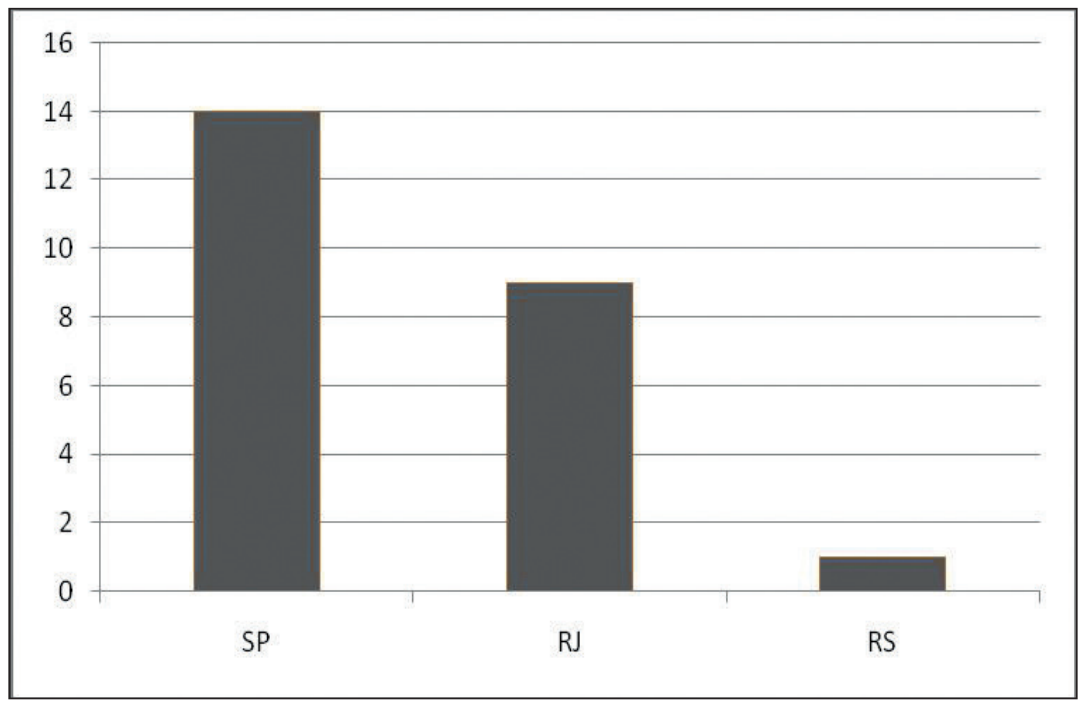

Figura 6.I. Gráfico das editoras do projeto "Literatura em minha casa" por estados. 


\subsection{Autores e ilustradores recorrentes nos acervos: o cânone estabelecido}

Em estudo já citado a respeito da perspectiva editorial dos livros voltados à educação infantil, Magda Soares (2008) faz um levantamento dos autores com maior número de livros inscritos para o PNBE/2008. Soares constata que autores nacionalmente reconhecidos e de prestígio consolidado - Ana Maria Machado, Ziraldo, Tatiana Belinky, Mary e Eliardo França, Sylvia Orthof, Elias José, Ruth Rocha, Eva Furnari e Maria Clara Machado - têm um maior número de livros inscritos, independentemente das editoras que os inscrevem (Idem, p. 26). Nosso trabalho difere do de Soares na medida em que analisa as obras escolhidas para compor os acervos do PNBE nos anos do projeto "Literatura em minha casa" após a seleção por especialistas.

Nossa hipótese inicial, acerca da existência de um cânone literário infantojuvenil estabelecido, com autores, ilustradores e obras consagradas, que estariam acima dos critérios de diversidade previstos nos editais do PNBE nos anos de 200I, 2002 e 2003, foi confirmada, com um grande número de autores canônicos tanto da literatura de menor idade como da literatura adulta brasileira (Tabela 6.I). Verificamos que autores como Sylvia Orthof, Ana Maria Machado, Olavo Bilac, Cecília Meireles e Machado de Assis são numerosos nos livros e nas antologias de poemas e contos. A qualidade dos textos desses autores - representativos da produçáo literária brasileira, conforme previam os editais de convocaçáo das obras - e a boa receptividade em relação aos leitores, vale a pena lembrarmos, são inquestionáveis. Entretanto, essa recorrência pode criar no leitor iniciante a ideia de que apenas algumas obras, de alguns autores, são literárias. 
Tabela 6.I. Autores mais recorrentes no projeto "Literatura em Minha Casa"

\begin{tabular}{|c|c|c|}
\hline Ranking & Autor & $\begin{array}{l}\text { Número } \\
\text { de livros }\end{array}$ \\
\hline $\mathrm{I}^{\mathrm{o}}$ & Sylvia Orthof & I4 \\
\hline $2^{\circ}$ & Ana Maria Machado & $\mathrm{I} 2$ \\
\hline $3^{\circ}$ & Olavo Bilac & IO \\
\hline \multirow[t]{2}{*}{$4^{\circ}$} & Cecília Meireles & \multirow[t]{2}{*}{8} \\
\hline & Machado de Assis & \\
\hline \multirow[t]{3}{*}{$5^{\circ}$} & Moacyr Scliar & \multirow[t]{3}{*}{7} \\
\hline & Pedro Bandeira & \\
\hline & Ruth Rocha & \\
\hline \multirow[t]{6}{*}{$6^{\circ}$} & Carlos Drummond de Andrade & \multirow[t]{6}{*}{6} \\
\hline & Henriqueta Lisboa & \\
\hline & José Paulo Paes & \\
\hline & Leo Cunha & \\
\hline & Manuel Bandeira & \\
\hline & Mário Quintana & \\
\hline
\end{tabular}

Ressaltamos ainda que tanto no estudo de Soares (2008), a respeito dos autores com maior número de obras inscritas para o acervo do PNBE/2008, como em nossa análise dos autores mais recorrentes nas obras escolhidas para os acervos do PNBE em 200I, 2002 e 2003, destacam-se os nomes de Ana Maria Machado, Sylvia Orthof e Ruth Rocha, ${ }^{4}$ consagradas escritoras de literatura infantojuvenil.

Com a análise do total de i9i dos autores, brasileiros e estrangeiros, os resultados apontaram para I4,I4\% de escritores estrangeiros ou naturalizados brasileiros; $56,54 \%$ (mais da metade) ori-

\footnotetext{
4 É relevante destacar que Ana Maria Machado recebeu, entre outros prêmios importantes, a medalha internacional Hans Christian Andersen, em 2000, considerado o Nobel da Literatura para Crianças e Jovens. Sylvia Orthof, por sua vez, foi ganhadora, também entre outros, do Prêmio Jabuti, em 1997. Ruth Rocha já foi premiada quatro vezes pela Câmara Brasileira do Livro, por seu trabalho de ficçấo em literatura infantil, entre outras premiações.
} 
ginários da Região Sudeste; 8,90\% nascidos na região Sul; 2,62\% da região Centro-Oeste; 2,62\% da Região Norte; e, finalmente, I5,I8\% originários da Região Nordeste (Figura 6.2).

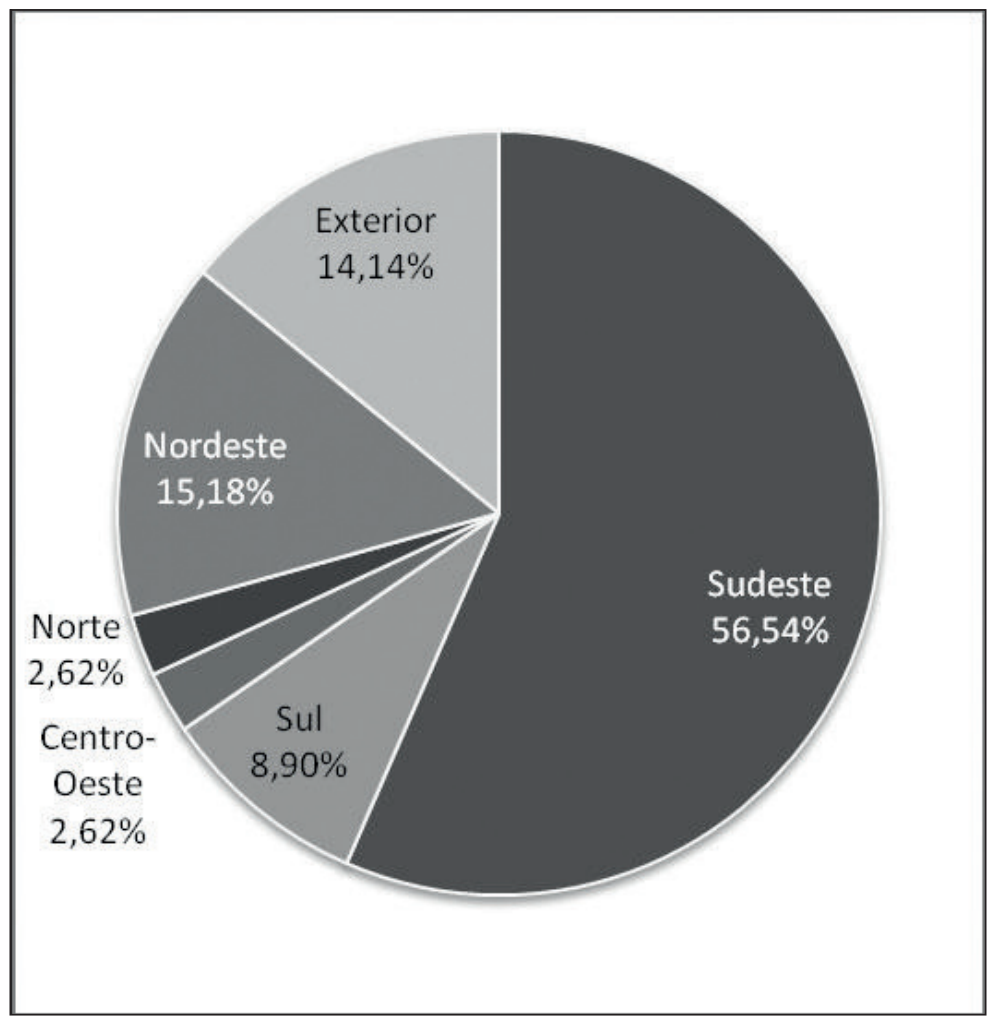

Figura 6.2. Local de nascimento dos autores do projeto "Literatura em Minha Casa” por regiōes do Brasil e do exterior.

Entre os ilustradores, constatamos menor repetição em relação à análise dos autores (Tabela 6.2): o número máximo de livros por ilustrador é seis (apenas $5 \%$ do acervo). 
Tabela 6.2. Ilustradores mais recorrentes no projeto Literatura em Minha Casa

\begin{tabular}{llc} 
Ranking & Ilustrador & Números de livros \\
\hline $\mathrm{I}^{\mathrm{o}}$ & Cláudia Scatamacchia & 6 \\
\cline { 2 - 2 } & Glenda Rubinstein & \\
\cline { 2 - 3 } & Orlando Pedroso & 5 \\
\hline $2^{\circ}$ & Pinky Wainer & \\
\cline { 2 - 3 } & Graça Lima & \\
\hline
\end{tabular}

Os resultados dos locais de origem apontaram para mais de 66 nascidos na Regiáo Sudeste do Brasil (Figura 6.3).

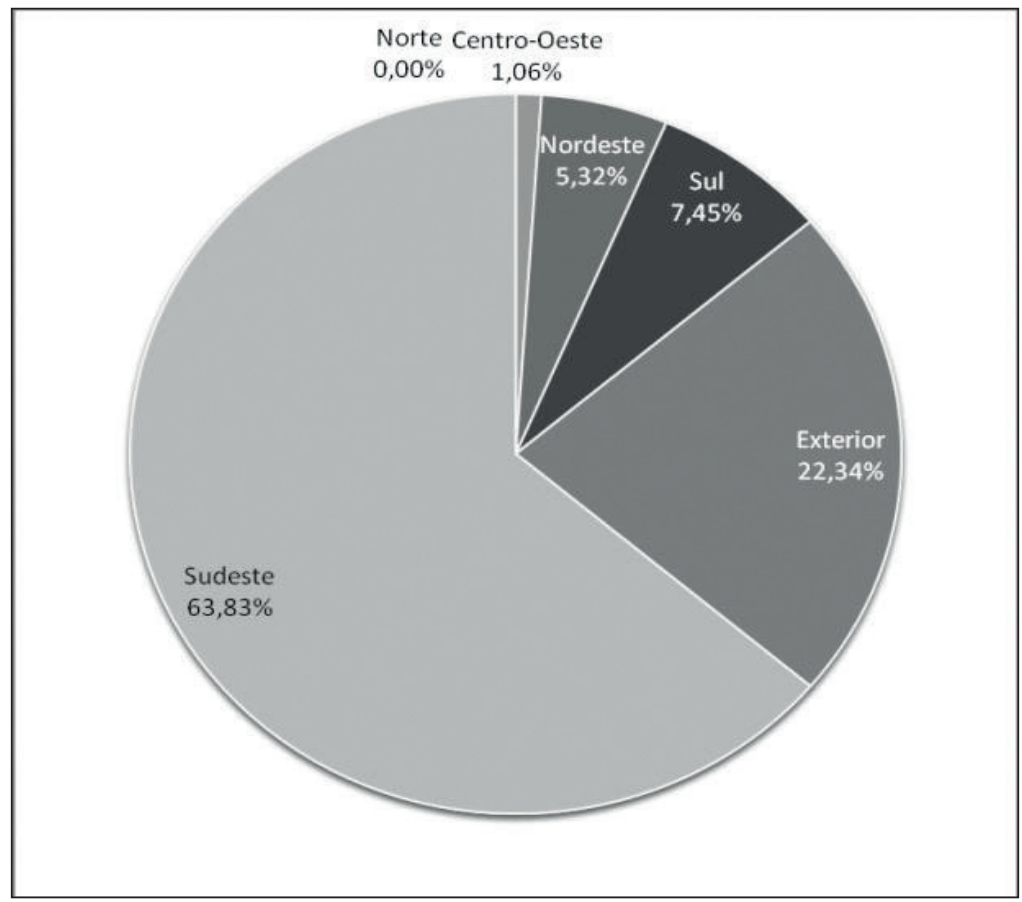

Figura 6.3. Local de nascimento dos ilustradores do projeto "Literatura em minha casa” por regiôes do Brasil e exterior 
Como vemos, sessenta ilustradores $(63,83 \%)$ dos livros em questão são nascidos na Região Sudeste do Brasil; 2I (22,34\%) são estrangeiros ou brasileiros naturalizados; sete $(7,45 \%)$ são nascidos na Regiāo Sul do país; cinco (5,32\%), na Região Nordeste; e apenas um (I,06\%) na Região Centro-Oeste. Dessa maneira, autores de diversas regióes - como previam os editais - e ilustradores (também objeto de nossa análise) não foram registrados em nossos resultados.

\subsection{Sobre o que fala a literatura infantojuvenil: temáticas}

Para abordar as temáticas, usamos a divisão tripartite proposta por Paiva (2008) em seu artigo "A produção literária para crianças: onipresença e ausência das temáticas". A autora discute as temáticas abordadas pelas obras de literatura infantil brasileira nos livros inscritos para o PNBE/2008. Aqui, em contrapartida, levantamos as temáticas recorrentes nas obras das coleçôes selecionadas para três anos do programa "Literatura em minha casa", que abarcam livros nacionais e estrangeiros, de diferentes épocas e regióes. A exemplo da autora das categorias propostas, e como já esclarecido, não temos pretensão de exaustividade nem de exclusividade em relação aos grupos propostos. As categorias propostas por Paiva (2008) são as seguintes:

I. A fantasia como tradiçáo: podem fazer parte dessa categoria livros de contos de fadas, fábulas, histórias de animais, fazendas, parques, circos, enfim temas que, por serem consagrados na literatura infantil, são os que mais agradam as crianças.

2. O conteúdo como opçáo: trata-se dos temas transversais, crescentes na produção literária voltada ao público infantil, apreciados por escolas e professores. Seus temas mais comuns são: ecologia, meio ambiente, inclusão social, questóes etnicorraciais etc. 
3. A realidade como aposta: aqui, estão obras que abordam temas de experiências cotidianas, vivenciadas por qualquer ser humano, independentemente da idade. Sáo questóes como morte, medo, abandono e separação, bem como sentimentos como amor, raiva, angústia, tristeza, ciúme, posse e perda.

Destacamos ainda que, em nossa análise, no caso das coletâneas de contos e poesias que compóem os acervos estudados, consideramos a maioria dos temas presentes na coletânea por inteiro, em número de textos, para a classificação dos livros.

Nossos resultados apontaram para aproximadamente $73 \%$ de títulos analisados com temáticas ligadas à fantasia; 6\% ligados a temas transversais; e 21\% ligados à realidade (Figura 6.4).

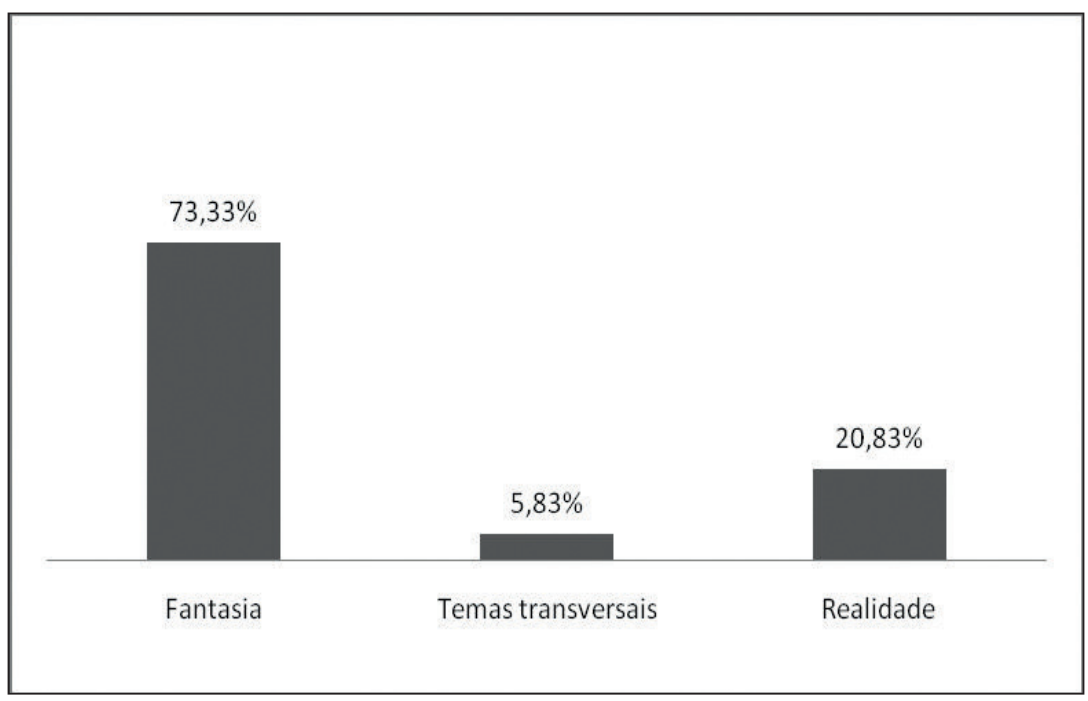

Figura 6.4. Distribuição em porcentagem das temáticas das obras que compõem os acervos do projeto "Literatura em minha casa" 
Verificamos, assim, que a literatura infantojuvenil, no corpus analisado, manteve a tradição das temáticas ligadas à fantasia tanto por serem consagradas na literatura infantil como por serem as que mais agradam as crianças (Paiva, 2008, p. 40) -, mas incorporou obras que abordam temas transversais e realidade.

\section{7 $\mathrm{O}$ local em que se passam as histórias infantojuvenis}

Buscamos mapear onde se passam as histórias dos livros escolhidos para as coleçôes do projeto "Literatura em minha casa". Para essa tarefa, dividimos os lugares em três categorias: lugar indefinido, Brasil e exterior. A segunda categoria (Brasil) ainda se divide nas regiôes do país: Sudeste, Sul, Nordeste, Norte e Centro-Oeste. Classificamos aqui os livros em que o local da história fica explícito, seja no texto, seja na ilustração. Salientamos ainda que, no caso das coletâneas, os livros com mais de uma história com lugares definidos (Brasil ou exterior) ou indefinidos foram contados mais de uma vez.

O gráfico a seguir aponta para os resultados gerais em proporção: com 60,63\% das histórias em lugares indefinidos; I4,I7\% na Região Sudeste do país; II,8I\% em países diversos; 6,30\% na Região Nordeste; 3,15\% na Regiấo Sul; 2,36\% na Região Norte; e I, $57 \%$ do total de livros com histórias que se desenrolam na Regiâo Centro-Oeste do Brasil. 


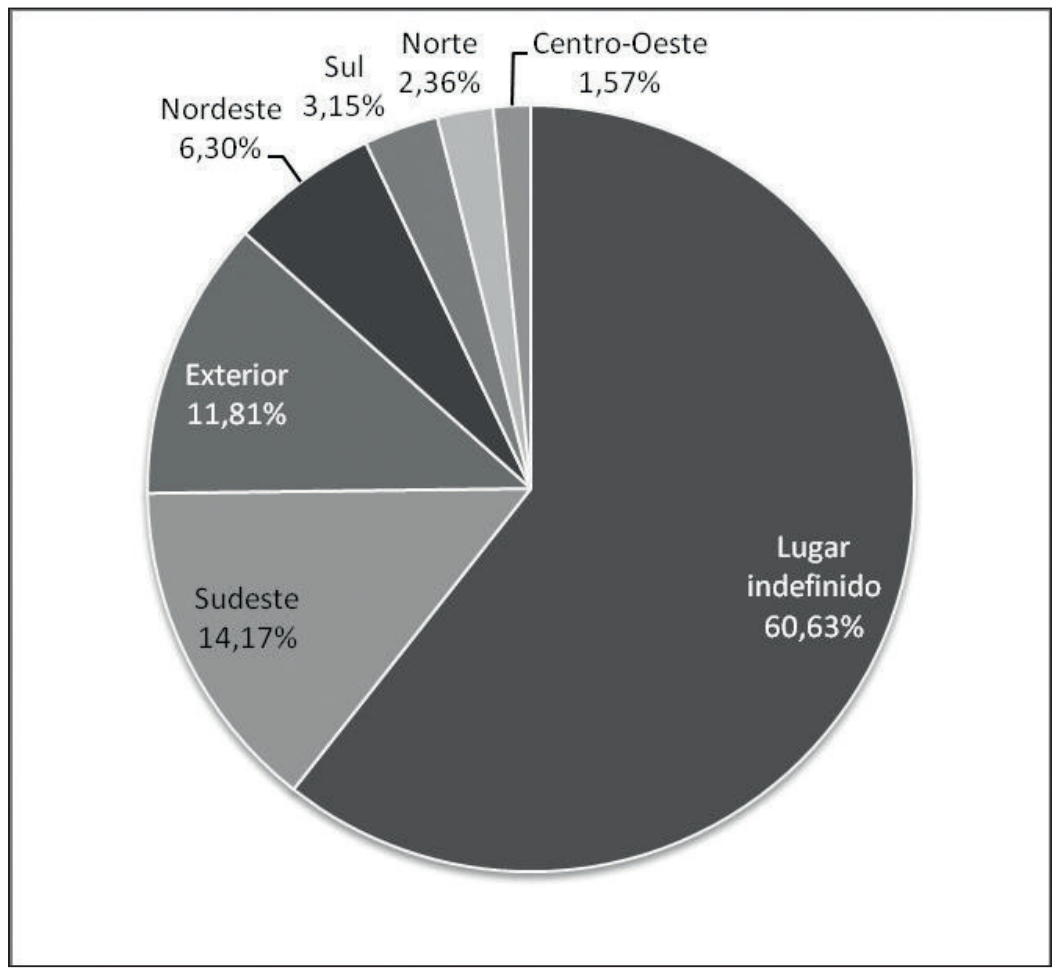

Figura 6.5. Histórias do projeto "Literatura em Minha Casa” que se passam em lugar indefinido, em regióes do Brasil ou no exterior.

As histórias das obras-alvo de nosso estudo se passam em lugares indefinidos (com frequência, fabulosos ou encantados, o que converge com a grande parte das histórias, que, em sua maioria, aborda temáticas ligadas à fantasia) $6 \mathrm{I} \%$ das vezes; aproximadamente $28 \%$ delas acontecem no Brasil; e I2\% se desenrolam em outros países. Entre os livros cujas histórias se situam no Brasil, grande parte se concentra na Região Sudeste. 


\subsection{Representaçáo e identidade: pluralidade cultural em questáo}

A pluralidade cultural é um dos temas transversais dos Parâmetros Curriculares Nacionais (Brasil, 1998), referindo-se ao desafio de respeitar os diferentes grupos étnicos e as diferentes culturas que compóem tanto a população brasileira como a mundial, a fim de que se conviva com grupos distintos e que essa característica se transforme em fator de enriquecimento cultural e de valorizaçáo da própria identidade cultural e regional.

Nesta pesquisa, objetivamos buscar as representaçóes ${ }^{5}$ de diferentes grupos brasileiros, no que se refere a etnia, cultura e regionalismo, nas obras do projeto "Literatura em Minha Casa", em especial aquelas destinadas às quartas e quintas séries do ensino fundamental, com base nos editais de convocação para a inscrição das obras do projeto. Esses editais prescreviam que as coleçôes deveriam "apresentar-se como um pequeno retrato da cultura brasileira” (Brasil, 200I; 2002; 2003), a qual é marcada pela diversidade.

Nosso estudo a respeito da pluralidade étnica dos personagens dos acervos mostrou que a quantidade de obras que contêm essa pluralidade (no total, 17 ) parece pequena em relação ao número daquelas distribuídas nos três anos (I20 obras). Ainda de acordo com os resultados, o espaço para personagens brancos, negros, índios e japoneses parece garantido na literatura infantojuvenil, embora nem sempre representem os mesmos papéis nem apareçam na mesma proporção. $O$ fato é que, sem dúvida, o aspecto da diversidade étnica é importante não só para que leitores de diferentes etnias se vejam representados nos livros e nas histórias que

5 Entendemos representação da mesma forma que Stuart Hall (1997). Para o autor, a representação liga o significado e a linguagem à cultura. Assim, representar é usar a língua/linguagem para dizer algo significativo ou representar o mundo de forma significativa. 
leem, mas para que também passem a respeitar e conviver com essas diferenças.

No que concerne à pluralidade cultural e às imagens de regionalismo, constatamos a presença de variados aspectos culturais e regionais de diferentes regióes do Brasil. Destacamos ainda a grande influência da cultura indígena no que concerne aos aspectos culturais do país. Essa diversidade, contudo, poderia ser ainda maior, já que foram localizadas apenas II obras com essa característica nos três acervos analisados, escolhidos a partir de um edital que previa que as coleçóes se apresentassem como um pequeno retrato da cultura brasileira.

No que diz respeito aos autores sul-matogrossenses e às imagens do regionalismo de Mato Grosso do Sul, encontramos aspectos naturais do Pantanal nas poesias do matogrossense Manoel de Barros presentes em três das antologias analisadas. No entanto, as temáticas abordadas pelo poeta nas obras em questão (Palavras de encantamento, do acervo de 200I; $A$ poesia dos bichos, do acervo de 2002; e Fazedores do amanhecer, do acervo de 2003) abordam assuntos universais. Evidenciamos aqui a lacuna nos acervos no que se refere a autores do Mato Grosso do Sul e imagens do regional sul-matogrossense, já que apenas três antologias apresentam representaçóes desse estado.

\subsection{Consideraçóes sobre alguns aspectos dos acervos selecionados}

A motivação inicial para a realização deste trabalho foi estudar a literatura infantojuvenil que circula nas escolas. Dessa maneira, cientes de que o governo é o maior comprador do gênero, buscamos verificar quais livros literários têm sido comprados e enviados às escolas públicas de todo o país, a fim de averiguar o que 
tem sido apontado como "boa literatura" pelo governo nos últimos anos.

Nessa perspectiva, tendo o projeto "Literatura em minha casa" como objeto de estudo, analisamos não só os autores, os ilustradores mais recorrentes e os critérios de seleção das compras, mas também as temáticas mais frequentes, o espaço físico em que se passam as histórias, a presença de imagens de pluralidade étnica, cultural, imagens de regionalismo e, por fim, do regional sul-matogrossense.

Em suma, as coleçôes do projeto "Literatura em minha casa" contemplaram obras de diferentes gêneros literários: poesia, conto, novela, texto de tradição popular, clássico universal e peça teatral. Os critérios de seleção foram, de modo geral, três: um primeiro, que diz respeito à triagem (referentes à análise da estrutura editorial); um segundo, que diz respeito aos critérios de avaliação e seleção (tipologia, temática, seleção de títulos e autores, textualidade, projeto gráfico e ilustraçóes e projeto editorial); e um terceiro, relativo às especificaçôes técnicas mínimas (formato, capa, miolo e acabamento). Também registramos repetiçóes nos acervos, com obras repetidas do acervo de 1999 em 200I e 2002, e obras repetidas (não obras iguais, mas do mesmo autor e com os mesmos personagens) no acervo de 2003, o que atenta contra o aspecto da diversidade proposta nos editais.

Somada aos dados referentes ao mercado editorial do projeto "Literatura em minha casa", a análise dos autores e ilustradores, bem como de seus locais de origem, reforça os resultados iniciais, no sentido de que a Regiáo Sudeste predomina não somente na produção editorial dos livros dos anos em questáo, como também na escrita e na ilustração das obras escolhidas. Nesses acervos, não se encontrou diversidade de autores e ilustradores de diferentes regiốes, conforme previam os editais de convocação para 
a inscrição das obras de literatura nos três anos do projeto "Literatura em minha casa".

Verificamos, ainda, a recorrência de autores consagrados, tanto da própria literatura de menor idade como da literatura adulta brasileira, formando uma espécie de cânone nos três acervos estudados. No que se refere aos ilustradores, constatamos que náo há uma repetição tão grande quanto a de autores nas coleçóes analisadas.

A literatura infantojuvenil, no corpus analisado, manteve a tradição das temáticas ligadas à fantasia, mas incorporou obras que abordam temas transversais e realidade. Também confirmamos que, em sua maioria, as histórias dos livros se passam em um lugar indeterminado. Comprovamos também que, entre os livros cujas histórias se passam no Brasil, grande parte se concentra na Região Sudeste.

No que diz respeito à pluralidade étnica, verificamos a presença de personagens brancos, negros, índios e japoneses, embora estes últimos nem sempre tenham o mesmo espaço ou representem os mesmos papéis. Em relação à pluralidade cultural e às imagens de regionalismo, encontramos imagens de diferentes culturas e aspectos regionais de diferentes partes do país, que, entretanto, aparecem em pequena proporção nos três acervos estudados. Por fim, nas poesias de Manoel de Barros que compóem apenas três antologias (destaca-se a lacuna de autores do Mato Grosso do Sul), constatamos a presença de poemas que, embora destaquem os recursos naturais do Pantanal matogrossense, abordam assuntos universais.

A desproporção entre as obras que retratam a diversidade étnica, cultural e regional do Brasil e o total daquelas que compóem os acervos estudados parece apontar para dificuldades de representação dessas características plurais de nosso país na literatura infantojuvenil, seja pela ausência de obras que abordem tais repre- 
sentações, seja em função da predominância e da canonicidade de alguns autores nos três acervos analisados.

Se, por um lado, esses resultados apontam para alguns aspectos das obras do gênero que circulam nas escolas hoje, por outro, nosso estudo apresenta representaçóes étnicas e culturais que, como já dito, não se esgotam na presente pesquisa e que podem ser retomadas em estudos posteriores, inclusive com pesquisas de campo, para que se averigue a recepção dos leitores das diversas regióes do país que se veem ou não representados nas obras.

Para finalizar, esperamos ter contribuído para o melhor entendimento não só de alguns aspectos da literatura infantojuvenil que circula nas escolas públicas de nosso país, como também da importância das políticas públicas de leitura, especialmente os programas de compras de livros literários, para a formação de leitores. Retomando a fala de Meireles (1984), esses programas visam garantir aos alunos não só passatempo, mas também a nutrição do intelecto e da sensibilidade.

\section{Referências}

AZEVEDO, Ricardo. "Aspectos da literatura infantil no Brasil, hoje". Revista Releitura, Belo Horizonte, n. I5, abril de 200I. Disponível em: <http:// www.ricardoazevedo.com.br/Artigoo3.htm>. Acesso em 30 jan. 2017.

BRASIL. Parâmetros Curriculares Nacionais: pluralidade cultural. Brasília: Ministério da Educação e Cultura/Secretaria de Educação Fundamental, 1998. Disponível em: <http://www.dominiopublico.gov.br/download/texto/ meoooo42.pdf $>$. Acesso em 3 fev. 2017.

. Edital de convocação para inscrição de coleçōes de obras de literatura no processo de avaliação e seleção para o Programa Nacional Biblioteca da Escola, PNBE/200I. Brasília, 29 de agosto de 200 . 
- Edital de convocação para inscrição de coleçóes de obras de literatura no processo de avaliação e seleção para o Programa Nacional Biblioteca da Escola, PNBE/2002. Brasília, 24 de abril de 2002.

. Ministério da Educação. Edital de convocação para inscriçãa de coleçôes de obras de literatura para alunos de $4^{a}$ e 8 a séries do ensino fundamental e de literatura de informação para alunos da Educação de Jovens e Adultos (EJA), no processo de avaliação e seleção para o Programa Nacional Biblioteca da Escola (PNBE/2003). Brasília, 9 de maio de 2003.

FERNANDES, Célia Regina Delácio. Leitura, literatura infantojuvenil e educaçâo. Londrina: EDUEL, 2007.

. "A seleçáo de obras literárias para o Programa Nacional Biblioteca da Escola - PNBE 2006-20I4". Estudos de literatura brasileira contemporânea, n. 5I, pp. 22I-44, maio/ago. 2017.

e CORDEIRO, M. B. da S. "Os critérios de avaliação e seleção do PNBE: um estudo diacrônico". Revista Educação (PUC-RS, online), v. 35, pp. 319-28, 2012.

HALL, Stuart. "The work of representation". In (org.). Representation: Cultural Representation and Cultural Signifying Practices. Londres: Thousand Oaks/Nova Déli: Sage/Open University, I997.

IBGE: INSTITUTO BRASILEIRO DE GEOGRAFIA E ESTATÍSTICA. Contagem da População 2007. Disponível em <http://www.ibge.gov. br/home/estatistica/populacao/contagem2007/contagem_final/tabelai_I. pdf $>$. Acesso em 30 de janeiro de 2017.

. Contas Regionais do Brasil 2003-2007. Disponível em: <http://www. ibge.gov.br/home/estatistica/economia/contasregionais/2003_2007/tabelao2.pdf>. Acesso em 30 de janeiro de 2017.

INSTITUTO PRÓ-LIVRO. Retratos da leitura no Brasil 2. Disponível em: $<$ http://www.prolivro.org.br/ipl/publier4.o/dados/anexos/48.pdf>. Acesso em 30 jan. 2017.

. Retratos da leitura no Brasil 3. Organização de Zoara Failla. São Paulo: Imprensa Oficial do Estado de São Paulo, 2012. 
. Retratos da leitura no Brasil 4. Organização de Zoara Failla. Rio de Janeiro: Sextante, 2016.

LAJOLO, Marisa. Meus alunos não gostam de ler: o que eu faço? Campinas: CEFIEL, 2005.

LISPECTOR, Clarice. "Felicidade clandestina”. In __ et al. Em família. Rio de Janeiro: Nova Fronteira, 2002, v. 2, pp. 38-42. (Coleção Literatura em Minha Casa.)

MEIRELES, Cecília. Problemas da literatura infantil. 3 ed. Rio de Janeiro: Nova Fronteira, 1984.

NASCIMENTO, I. "A leitura como moeda de trânsito social: entrevista com Marisa Lajolo”. In __. Politicas e práticas de leitura no Brasil. São Paulo: Ação Educativa, 2003, pp. 46-57.

PAIVA, Aparecida. "A produção literária para crianças: onipresença e ausência de temáticas". In __ e SOARES, M. Literatura infantil: politicas e concepçôes. Belo Horizonte: Autêntica, 2008, pp. 35-52.

PAULA, Flávia Ferreira de. Literatura infantojuvenil e politicas públicas de leitura: um estudo do projeto Literatura em minha casa (dissertação). Universidade Federal da Grande Dourados, 20Io. II6f.

e FERNANDES, C. R. D. "Políticas públicas de leitura e formação de leitores: um estudo do projeto 'Literatura em Minha Casa'. Seminário de teses em andamento, 20II, Campinas. Anais..., 2010, v. 5, pp. 383-99.

e ___ . "Literatura infantojuvenil, políticas públicas de leitura e formação de leitores". Revista de Políticas Públicas, v. I8, pp. 587-60I, 2014. e . "Pluralidade cultural na literatura infantojuvenil brasileira: projeto 'Literatura em minha casa' em questáo”. Acta Scientiarum. Language and Culture. Maringá, v. 38, n. 3, pp. 233-4I, jul.-set., 2016.

SOARES, Magda. "Livros para educação infantil: a perspectiva editorial". In PAIVA, A. e SOARES, M. (orgs.). Literatura infantil: políticas e concep̧̧óes. Belo Horizonte: Autêntica, 2008, pp. 2I-34. 


\section{7 \\ Literatura juvenil brasileira: espaço e representação social em acervo do PNBE $^{1}$}

Mirian Hisae Yaegashi Zappone

\section{I Problematizando a representaçáo na literatura brasileira: duas pesquisas}

Em 1985, Fúlvia Rosemberg publicava Literatura infantil $e$ ideologia, texto no qual apresentava resultados de uma pesquisa analisando 168 livros infantojuvenis brasileiros editados ou reeditados entre os anos de 1955 e 1975 e que circulavam no mercado editorial brasileiro. Recorrendo a uma abordagem quali-quantitativa, a pesquisadora tinha por objetivo estudar a relação entre adultos e crianças, examinando a bipolarização dominador-dominado a partir da observação de categorias relacionadas a idade, sexo, cor e etnia dos personagens dos livros. Suas unidades de análise foram as personagens presentes na ilustração, no texto e em seus comportamentos.

Os achados de Rosemberg (I985) figuraram, na década de I980, como um dos primeiros panoramas sobre representação social da literatura infantojuvenil. A partir de dados qualitativos, a autora observou que, na esfera da produção, a maior parte dos agentes eram homens atuando como autores, ilustradores ou diagramadores. Do total de narrativas, observou que 90\% delas haviam sido produzidas no eixo Rio-São Paulo, evidenciando

I Este texto foi publicado na revista Teias, v. I6, n. 4I (20I5), e adaptado para este livro. 
que os maiores centros tendem a "impor os produtos culturais que lhes são específicos a outras populações que possuem traços próprios, fazendo eclodir, ou mesmo destruindo suas peculiaridades" (p. 46). Quanto à autoria, verificou-se que era frequentemente masculina (78\% autores versus $28 \%$ autoras), com predominância de autores maduros (com idades entre 40 a 59 anos), nascidos antes de 1920 .

$\mathrm{Na}$ análise das personagens, outros pontos chamaram a atenção: as mulheres eram minoria dentro das histórias e apareciam, quase sempre, como coadjuvantes, pois as aventuras eram frequentemente vivenciadas por meninos. Sobre a cor e a raça das personagens, a autora chama a atenção para as estratégias discriminatórias e veladas que estavam presentes nas narrativas estudadas e sobre a discriminação sofrida por grupos minoritários como negros e índios.

Chamava a atenção o caráter modelar da maioria das personagens que atuavam no sentido de construir uma narrativa didatizante em que o maniqueísmo da equação bem versus mal servia à pedagogia do exemplo aos leitores em formação. Por isso, temas como sexo ou morte não apareceram nas histórias estudadas. $\mathrm{O}$ panorama apresentado pela autora evidenciava, naquele momento, o pouco prestígio da produçáo literária voltada à infância e à juventude quando ainda não se via nela o grande filão mercadológico em que se transformaria ao longo das décadas de i980 e I990, alavancado, no século XXI, pelas compras governamentais.

Anos depois, outro estudo de caráter quali-quantitativo seria realizado por Regina Dalcastagnè, tendo, entretanto, como corpus investigativo, o romance brasileiro contemporâneo. Também com o objetivo de estudar a personagem, a pesquisa de Dalcastagnè abarcou 285 romances publicados por casas editorais representativas no campo literário brasileiro, produzidos no período de 1994 a 2009. Essa pesquisa resultou no levantamento de I.245 persona- 
gens - aquelas de importância maior na trama, sem, contudo, reduzir-se às protagonistas.

Embora as duas pesquisas possuam um intervalo temporal de mais de 30 anos, os resultados encontrados apresentam muito mais semelhanças do que diferenças. Segundo Dalcastagnè (2007), a produção literária continua a ser uma atividade predominantemente masculina, pois a autoria feminina não chega a $30 \%$, contra os $72,7 \%$ de autoria masculina. Além da homogeneidade em relação ao gênero, chama a atenção o fato de 93,3\% dos autores serem brancos e com escolarização superior, além de estarem estabelecidos, quase todos (90,3\%), nas grandes capitais.

Em relação às narrativas, Dalcastagnè (2007) mostra que o espaço das histórias é frequentemente a metrópole $(82,6 \%)$, em detrimento dos espaços rurais (I4,3\%) e das cidades médias (37,2\%). Quanto ao sexo, houve predominância de personagens masculinos $(62,1 \%)$ contra apenas $37,8 \%$ de personagens femininos. Quando esses dados são analisados em relação à posição dos sexos na narrativa, fica evidente a maior importância dispensada aos personagens masculinos: 71,1\% dos protagonistas são homens e apenas $28,9 \%$, mulheres. Com relação à orientação sexual, ou seja, "à direção do desejo da personagem" (p. I7), a heterossexualidade foi maciça, abarcando $8 \mathrm{I} \%$ dos personagens, sendo a homossexualidade observada apenas em 3,9\% dos casos.

Em relação à cor da personagem no romance brasileiro contemporâneo, $79,8 \%$ dos personagens sáo brancos, $7,9 \%$, negros, 6,I\%, mestiços e I, $2 \%$ indígenas, evidenciando uma presença muito pequena das comunidades não brancas, muito embora, no Brasil, sejam a maioria.

Esses dados são apresentados aqui não apenas por inventariar pesquisas quali-quantitativas sobre a literatura brasileira, mas também pelos achados que nelas problematizam uma questão ainda maior: a da representação. Na pluralidade das representa- 
ções de mundos e de seres, a literatura pode preencher nossa necessidade de ficção e levar, como aponta Candido (1992), a um conhecimento do mundo e do ser ao representá-los na forma de um romance, por exemplo. Entretanto, a palavra representação, tanto no caso da literatura juvenil como no da literatura em geral, deve ser aqui problematizada. Representar, segundo o Dicionário Aurélio, significa "ser a imagem ou a reprodução de" (Ferreira, I995, p. 564), significado semelhante ao do termo imitação, referido por Aristóteles ao comentar, em sua Poética, a natureza das composiçôes literárias. Para esse pensador, o traço distintivo das composiçóes literárias seria o modo pelo qual patrocinavam a imitação das coisas ou sua representação (Aristóteles, I98I, p. I9). Assim, a literatura imita a realidade, representando, por meio de figuraçôes miméticas distintas, os diversos elementos de tal realidade - espaço, tempo, pessoas, situaçóes, modos de pensar e de conceber a realidade etc.

A crítica literária esteve, por bastante tempo, ocupada exatamente com os modos da imitação, ou seja, com as diferentes técnicas empregadas pelos autores para criar suas obras. Assim, o grande tema dos estudos literários foi a descrição dos procedimentos de criação literária, ou seja, os modos de representação ou de imitação que a literatura efetuava. Em poucas situaçôes, houve preocupação com os seres, situaçóes ou realidades representados nos livros e romances. No entanto, uma questáo que se apresenta para a crítica literária e que, neste texto, revela-se como um problema de pesquisa não é apenas a estético ser pensada em termos de parâmetros distintos, mas também em que medida a literatura, especialmente a literatura juvenil brasileira, tem conseguido representar as diferentes realidades e os diferentes grupos sociais que configuram a sociedade brasileira. Sobre essa questão, Dalcastagnè (2008) pondera: "O que se coloca hoje não é simplesmente o fato de que a literatura fornece determinadas representaçóes da 
realidade, mas sim que essas representaçôes não são representativas do conjunto das perspectivas sociais" (p. 4).

Essa preocupação parece ser bastante pertinente quando cotejamos as pesquisas de Rosemberg (1985) e Dalcastagnè (2008), em que se desenham os mesmos cenários: um mundo urbano com mais proeminência de homens do que de mulheres, branco, de classe média e heterossexual, o que leva a inferir que o romance brasileiro, tanto o adulto como o juvenil, apresenta um recorte enviesado da sociedade, bastante atrelado à perspectiva de seus produtores.

De acordo com Chartier (1990), a representação é "instrumento de um conhecimento mediador que faz ver um objeto ausente através da substituição por uma imagem capaz de o reconstituir em memória e de o figurar como ele é" (p. Io). Assim, a coisa ou o ser representado revelam o modo como seu criador os vê. Segundo Compagnon (2006), para Aristóteles, a representação visava não ao estudo das relaçôes entre literatura e realidade, mas à ação, à produção da ficção poética verossímil. Portanto, a mimesis aristotélica, para o autor, "seria a representação de açôes humanas pela linguagem [...] e o que lhe interessa é o arranjo narrativo dos fatos em história" (p. IO4). Modernamente, os estudos da mimesis não a aceitam mais como uma simples cópia da realidade; ela constitui uma forma especial de conhecimento do mundo humano que inclui o tempo do reconhecimento. A mimesis, ou representação, passa a ser problematizada pela teoria literária de modo a se dispensar atenção à realidade, ao referente construído por aquele que produz a obra literária e também ao modo como os públicos podem conceder-lhe significados.

Representar em literatura é, entáo, criar um mundo segundo a ótica do criador e, portanto, também "falar em nome do outro", como salienta Dalcastagnè. Ao se manifestar pelo outro, o discurso de um interlocutor acaba por legitimar a presença daquele com 
maior competência, o que causa, na maioria das vezes, o silêncio de quem é representado. Apenas o discurso com reconhecimento social acaba por ter valor. De acordo com Dalcastagnè (2008), em geral, na imposição de um discurso, a legitimação acontece em razão da justificativa do maior esclarecimento, da maior eficácia social deste sobre o outro, sobre aquele que é silenciado. Com relação à representação, ainda segundo a pesquisadora, uma única forma de olhar a sociedade pode não representar, de modo condizente, os diferentes grupos que a formam. Surge, assim, a questáo da legitimidade: quando um texto literário ou qualquer outra manifestação simbólica representam um grupo ou um indivíduo por formas socialmente reconhecidas, as identidades desses grupos e indivíduos passam a ser legitimadas: ou seja, a representação não só patrocina a mímese, como também ajuda a constituir a própria realidade - afinal, a linguagem constrói o mundo. Por essa razão, é importante discutir a ausência ou a presença de determinados grupos sociais nas expressóes artísticas, especialmente de textos literários que podem circular na escola, tais como aqueles dos acervos do Programa Nacional Biblioteca na Escola (PNBE).

Numa sociedade multifacetada por traços raciais, por diferentes condiçôes econômicas, por crenças religiosas plurais e outros, cabe problematizar levando em conta o valor da literatura juvenil brasileira como bem cultural significativo na formação de leitores. Além disso, é preciso efetuar um levantamento sobre como as narrativas da literatura juvenil brasileira contemporânea lida e difundida na e pela escola têm efetuado a representação dos grupos sociais que compóem nossas cultura e população, e sobre as implicaçóes dessa representação no caso da formação de leitores que recebem essa literatura como um conjunto de textos de valor, mas com o qual, muitas vezes, pode não se identificar ou se identificar muito pouco. 


\subsection{Delineando o corpus da pesquisa: literatura juvenil e o PNBE}

Em 1997, o Fundo Nacional de Desenvolvimento da Educação (FNDE) criou o Programa Nacional Biblioteca na Escola (PNBE), como uma das açôes da política de fomento da leitura elaboradas pelo Ministério da Educação. Tendo em vista a baixa posse de livros nos lares brasileiros e as poucas bibliotecas escolares e públicas, como demonstram pesquisas como "Retratos da leitura” (Instituto Pró-Livro, 20II; 20I3), o programa tem por objetivo o acesso da comunidade escolar e náo escolar à informação e à cultura, seja por meio de acervos de obras de referência, seja de obras para a formação de professores, seja ainda de periódicos e de obras de literatura em geral. Anualmente, por meio de portaria ministerial, um colegiado formado por representantes do Conselho Nacional de Secretários da Educação, da União Nacional de Dirigentes Municipais de Educação (Undime), do Programa Nacional de Incentivo à Leitura (Proler), de intelectuais e de especialistas das áreas de leitura, literatura e educação de universidades públicas e do Ministério da Educação atua para avaliar as obras inscritas no programa. Após essa avaliação, que abarca quesitos como qualidade gráfico-editorial, material, estética e temática das obras, são divulgadas as listas com as obras selecionadas para o programa e que seráo enviadas às escolas.

Por sua consistência e duração, o PNBE se configura como uma das mais bem organizadas políticas de incentivo à leitura, ao menos em termos operacionais, levando-se em conta que náo existem estatísticas no site do FNDE sobre a real apropriação dos textos pelos alunos, e poucos são os estudos realizados sobre sua recepção nas escolas, seja por parte de professores, seja por parte de alunos. Chamam a atenção os números e as cifras do programa, que procura atender escolas brasileiras de ensino básico, ge- 
rando cifras que chegam a milhóes. Os dados dos últimos quatro anos do programa ${ }^{2}$ apontam que os anos finais da educaçáo básica foram contemplados com acervos literários, respectivamente, em 2OII e 20I3. Especificamente em 20I3, foram adquiridos mais de cinco milhôes de livros distribuídos em 50.556 escolas do ensino fundamental. Embora seja um programa dispendioso, o PNBE se consolidou, ao longo dos anos de sua execução, como política de Estado, por uma razão especialmente significativa: sua abrangência junto ao público visado - alunos de todas as escolas brasileiras do ensino básico.

Ao considerar a noção de campo literário, tal como Bordieu (20I3) formula, como espaço simbólico em que atuam crítica acadêmica, autores, público e demais instâncias mediadoras (editores, editoras, agentes literários etc.), compondo um campo de força que visa ao reconhecimento e ao prestígio - campo no qual seja possível assegurar não apenas suas predileçóes artísticas e seu conjunto de valores, como também o próprio direito de manifestá-las na qualidade de autoridade competente para tanto -, não seria impertinente considerar o PNBE uma instância de legitimação significativa no contexto de um subcampo da literatura juvenil brasileira.

Por essa razão, ao se pensar no problema da valoração na literatura juvenil contemporânea, os acervos de literatura do PNBE passam a ter um caráter bastante representativo, já que sua seleção é duplamente avalizada: tem a fiança da academia, pois os avaliadores das obras são professores universitários especialistas na área e, ao mesmo tempo, recebe a chancela governamental, como um patrimônio cultural digno de figurar como "clássico", ou seja, bem cultural que pode circular na classe, na sala de aula.

2 Os dados específicos sobre a quantidade de livros adquiridos, escolas beneficiadas e valores investidos podem ser encontrados em: <http://www.fnde.gov.br/programas/biblioteca-da-escola/biblioteca-da-escola-dados-estatisticos $>$. Acesso em I2 maio 2015 . 
Considerando, pois, a importância dos acervos do PNBE no campo literário em que se circunscreve a literatura infantil e juvenil, objetivou-se realizar, em moldes similares ao das pesquisas de Rosemberg (1985) e de Dalcastagnè (2008), um estudo sobre os personagens da literatura juvenil contemporânea, com vistas a verificar, de modo diacrônico, como são representados os personagens. Nesse sentido, selecionou-se para o corpus o acervo PNBE 2013 destinado aos anos finais do ensino fundamental, por ser o acervo mais recente de obras literárias e por abarcar textos voltados ao público juvenil. Tal acervo contava com I8o textos, dos quais foram selecionadas apenas as narrativas longas (novelas ou romances), uma vez que havia outros gêneros (poesia, quadrinhos, biografias, memórias, contos e novelas).

Feita a seleção do corpus, foram totalizados 56 textos contemporâneos, todos produzidos a partir de $1980^{3}$ e estudados tomando por base uma metodologia quali-quantitativa, com a confecção de fichas para os personagens proeminentes, o que resultou num total de 235 personagens, todos analisados conforme a metodologia proposta por Dalcastagnè $(2007,2008) .{ }^{4}$

3 Adotamos a proposiçấo de Ceccantini (2000), no sentido de considerar contemporânea a produção realizada a partir de I980, não só por seu aspecto literário, mas também por coincidir com um momento histórico significativo na história brasileira: a derrubada do regime militar.

4 Ressaltamos que essa metodologia foi elaborada por Regina Dalcastagnè e aplicada, inicialmente, a romances da literatura brasileira contemporânea. Em seus trabalhos, a pesquisadora elabora questionários aplicados a personagens proeminentes, cujos dados são submetidos ao software Sphinx Léxica 5.o, que possibilita sua tabulação e seu cruzamento. Em função da importância das pesquisas de Dalcastagnè no contexto dos estudos da literatura brasileira contemporânea, bem como por sua contribuição metodológica para estudos que visam a levantamentos, valemo-nos, neste projeto, dos mesmos instrumentos de pesquisa por ela elaborados. Cf. Dalcastagne, 2007, pp. I-38. Disponível em: < http://cronopios.com.br/anexos/regina_dalcastagne.swf >. Acesso em O2/03/2OI2. 


\subsection{Narrativa juvenil contemporânea no acervo PNBE 20I3 e os contornos da cidade}

Entre as 56 narrativas estudadas, um dado que inicialmente chamou a atenção foi o aumento significativo da autoria feminina: diferentemente do panorama observado por Rosemberg, em 1985, 42,8\% dos textos do corpus foram produzidos por mulheres e $57,2 \%$, por homens. Embora ainda se note uma atuação mais efetiva dos homens, houve um crescimento significativo da autoria feminina, da ordem de quase $50 \%$, se compararmos esses dados com os da década de 1980 e até mesmo com as pesquisas de Dalcastagnè (2008) sobre o romance brasileiro contemporâneo, em que a autoria feminina representa apenas $27,2 \%$. Assim, no corpus observa-se uma visibilidade maior da produçáo literária de mulheres.

No que diz respeito ao tempo das histórias narradas, $60,7 \%$ delas foram ambientadas no contexto contemporâneo, ou seja, da década de 1980 aos dias atuais. Dez delas situaram-se em outros períodos históricos (notadamente no passado, como Atrás do paraiso, de Ivan Jaff, ou Sortes de Villamor, de Nilma Lacerda); oito, em períodos indefinidos; e quatro abarcaram o período da ditadura militar ( $O$ gênio do crime, de João Carlos Marinho; $O$ Golem do Bom Retiro, de Mário Teixeira; Quarto de despejo, de Carolina Maria de Jesus, e Anita Garibaldi, a estrela da tempestade, de Heloísa Prieto).

É interessante observar que a literatura juvenil brasileira do corpus opta pelo presente como tempo a ser representado, o que sinaliza uma preferência pela representação do universo circundante do leitor e pode facilitar não apenas o trato com a linguagem, mas também a apresentação de temáticas e problemas da vida contemporânea, como os conflitos emocionais de adolescentes diante dos dramas familiares e sociais, a exemplo de textos 
como A distância das coisas, de Flávio Carneiro, Um na estrada, de Caio Ritter, Jogo da memória, de Laura Bergalo, ou A mocinha do mercado central, de Stella Maris Rezende.

Nesse sentido, embora a tematização de tempos longínquos e indefinidos seja característica da literatura infantojuvenil, que está associada ao uso da fantasia, notou-se, no corpus estudado, maior prevalência de textos que preferem uma abordagem mais realista ao uso da fantasia. Assim, os textos distanciaram-se, por exemplo, do que observou Colomer ${ }^{5}$ (2003) sobre a literatura infantojuvenil contemporânea espanhola, tipicamente marcada pelo uso da fantasia (seja por meio do uso de animais humanizados, seja por meio de outros recursos) em detrimento da ficção realista, que, no corpus da autora, representou apenas $18,4 \%$.

As histórias contadas no corpus acontecem, em sua maioria, nas regióes Sudeste e Sul do Brasil, com 3I ocorrências ao todo, abarcando 55,3\% das histórias; Nordeste, seis ocorrências; Centro-Oeste, duas; e Norte, nenhuma. Esses últimos são cenários bem menos explorados, sendo suplantados até mesmo pela ambientação em regiốes estrangeiras (I4 ocorrências). Tal homogeneidade no trato da representação geográfica dos espaços das histórias pode, em parte, ser explicada pela inserção geográfica dos escritores brasileiros, que, em sua maioria, como demonstraram os estudos de Dalcastagnè (2008), concentram-se no Rio de Janeiro, em São Paulo, no Rio Grande do Sul e em Minas Gerais, o que faz com que suas histórias tendam a retratar essas regióes. Por se tratar de uma questáo sintomática, essa representação do espaço geográfico aponta para uma homogeneidade nada desejável na

\footnotetext{
5 Teresa Colomer (2003) realizou uma pesquisa sobre a literatura infantojuvenil espanhola, observando suas características constitutivas (em um recorte estruturalista) e suas temáticas. Para tanto, selecionou um conjunto de mais de mil títulos entre três seleçôes institucionais, a partir das quais procedeu "à escolha das obras que eram mais citadas nas listas de seleçôes ou que tinham obtido mais prêmios", o que resultou em um total de II8 títulos.
} 
caracterização do espaço na literatura juvenil, sobretudo no Brasil, onde as distinçôes culturais, linguísticas, sociais e geográficas são ricas e plurais.

Ainda reflexo da inserção de seus autores, as narrativas do corpus evidenciaram a proeminência dos espaços de grande porte com destaque para a cidade grande - e de médio porte. Contrariando certa tradição da literatura infantojuvenil brasileira, que, até aproximadamente a década de 1950, centrava suas histórias no campo ou em espaços fantásticos e maravilhosos, como assinalaram Zilberman e Lajolo (I985), a literatura juvenil contemporânea, seguindo o ritmo do desenvolvimento pós-industrial, adotou a cidade grande como locus privilegiado. Tratando-se de um aspecto importante para a construção das histórias, é preciso demarcar que a espacialidade não se restringe à caracterização geográfica ou arquitetônica do espaço; ela é também um vetor da cultura, que nela se instala e nela se refrata. Por essa razão, a espacialidade ganha um caráter social e também político mais amplo, o que, no caso do corpus estudado, parece fazer muito sentido, pois é um dos elementos que podem conter a chave de explicação do mundo representado nas narrativas, uma vez que nelas se observa a hegemonia cultural da cidade, nos moldes destacados por Fortuna e Silva (20II):

As cidades, desde então [desenvolvimento da industrialização], não apenas assistiram ao adensamento da residência, dos locais de oferta de trabalho e de consumo, como, concomitantemente, sofreram profundas alteraçôes nas condições e modos de vida social, política e institucional que albergam. Estas alteraçóes autorizam que caracterizemos o século XX como o tempo de consumação de um processo longo de urbanizaçáo da cultura, que traduz e consagra a plena hegemonia da cultura gerada nas cidades face a outras expressóes culturais não urbanas (pp. 43I-2). 
Entre as narrativas estudadas, $57 \%$ foram ambientadas em espaços urbanos de grande porte, $25 \%$ em espaços urbanos de médio porte, restando $25 \%$ para espaços campestres e pouco mais de I $4 \%$ para narrativas em espaços fantásticos/maravilhosos e de pequeno porte. Nota-se, pois, de modo efetivo, uma representação, nas narrativas estudadas, da hegemonia cultural dos grandes centros urbanos, fruto do desenvolvimento pós-industrial de molde liberal, fato já observado na literatura brasileira adulta, como alude Pechman (20I4) ao afirmar que "se constituiu entre nós essa literatura que fez da cidade, e mais do que isso, da experiência urbana e, até mais ainda, da convivialidade na cidade, o palco, o sujeito e o objeto de sua criação" (p. 90).

Como já assinalado, a espacialidade apresenta um traço cultural, sendo demarcada por questóes políticas e sociais. Refletindo sobre aos traços sociais presentes no corpus, observou-se que a hegemonia cultural da cidade consistir em um dado explicativo quando se analisa o estrato socioeconômico dos personagens. Conforme mostra a tabela a seguir, boa parte do universo humano pertence à classe média, que consiste em praticamente $50 \%$ das ocorrências, sendo minoritária a presença de pobres e da elite:

Tabela 7.I.

\begin{tabular}{lcc}
$\quad$ Estrato socioeconômico & Frequência. & \% \\
\hline Casse média & II 6 & $49.4 \%$ \\
\hline Elite & 45 & $\mathrm{I} 9.2 \%$ \\
\hline Pobre & 38 & $\mathrm{I} 6.2 \%$ \\
\hline Sem indício & 27 & $\mathrm{II} .5 \%$ \\
\hline Miserável & 4 & $\mathrm{I} .7 \%$ \\
\hline Mobilidade econômica ascendente & 4 & $\mathrm{I} .7 \%$ \\
\hline Náo resposta & $\mathrm{I}$ & $0.4 \%$ \\
\hline Mobilidade econômica descendente & $\mathrm{O}$ & $0.0 \%$ \\
\hline TOTAL OBS. & 235 & $\mathrm{I} \% 0$ \\
\hline
\end{tabular}

Fonte: Pesquisa Literatura juvenil contemporânea no acervo PNBE 2013: um estudo das representaçóes sociais, Universidade Estadual de Maringá. 
A presença maciça da classe média, longe de ser uma mera predileção dos autores ou mesmo de um aspecto de sua autorrepresentação, aparece nos textos como uma das consequências do processo de urbanização e do desenvolvimento econômico, o qual fez diminuir o contingente das classes minoritárias (ricos e pobres) $e$ ampliar os espaços da classe média, conferindo maior amplitude à sua cultura e a seu modus vivendi.

A moderna cultura urbana atenua as barreiras entre a "cultura do povo" e a "cultura de elite" que mantinham separadas e incomunicáveis as principais classes sociais do ancien régime. Em alternativa a esta polarização, gradualmente, assistiu-se à instauração de uma vida urbana, cultural e institucional mais agregadora e abrangente socialmente, de que ressalta o crescimento das classes médias que, neste contexto, ilustram uma espécie de convergência ao centro das classes sociais polares e das respectivas expressóes e produtos culturais típicos (Pechman, 20I4, p. 432).

Assim, o mundo representado nas narrativas é, sobretudo, o das classes intermediárias ou o da classe média brasileira $(76,6 \%$ dos personagens são brasileiros, contra apenas II, $9 \%$ de estrangeiros), cujo desenho familiar é fartamente apresentado. Afastando-se do sentido inicial de mero lugar da ação social ou da interação harmônica entre seus partícipes, o conceito de cidade, na contemporaneidade, deixa entrever fraturas, sobretudo aquelas ligadas ao modo como os sujeitos se movem nela: "a cidade é espaço do trânsito dos indivíduos que, influenciados pela lógica do capital, buscam a satisfação pessoal imediata de suas necessidades, valorizam o individualismo e a privacidade/domesticidade" (Fortuna, 20II, s.p.). É por essa razáo que grande parte das histórias narradas no corpus detém-se na construção de dramas pessoais, vivenciados a partir do núcleo familiar, numa espécie de fechamento do mun- 
do privado, fazendo crer como verdadeira, para essas narrativas, a afirmação de Pechman, no sentido de que "os atuais personagens da ficção urbana parecem completamente descompromissados com a cidade, e todo o caudal de urbanidade e sociabilidade que ela induz" (Idem, p. 9I). Nesse sentido, é sintomático constatar que o espaço restrito mais frequentado pelos personagens é o doméstico $(79,2 \%)$, com $50 \%$ a mais de ocorrências do que o segundo espaço mais frequentado - ruas e praças $(37 \%)$-, seguido de mata/campo/floresta (26\%), o que leva a se inferir que há uma de retração do espaço público e a consequente ampliaçáo do privado nas narrativas.

Entre os temas trabalhados nas 56 narrativas, observou-se a recorrência de alguns que foram englobados nas seguintes categorias: temas sociais (sete ocorrências), tais como preconceito racial, vida de classes pobres e miseráveis, disputa pela terra, processos de urbanização; temas familiares (dez ocorrências), como relacionamento entre pai e filho, relacionamento familiar, relação entre avô e neto, vivência conflituosa na família, novas configuraçôes familiares; temas do universo adolescente (com I5 ocorrências), em que se abordam, basicamente, os relacionamentos amorosos, o amadurecimento emocional do jovem e os conflitos familiares na adolescência. Além desses três temas, foram encontrados outros temas isolados: temas policiais ou detetivescos (cinco), leitura como processo criativo, história do Brasil, história das grandes navegaçóes, de quilombos e biografia romanceada.

Se a cidade grande é o espaço privilegiado nas narrativas estudadas, com sua arquitetura, suas ruas e suas praças, ou seja, a corporeidade material da cidade, ela cede lugar para a espacialidade social: é o local em que transitam grupos sociais específicos, entre os quais se destacam, no corpus estudado, o universo adolescente da classe média, cujo mundo circundante mais próximo é a família e, eventualmente, a escola. 
Entre as histórias que envolvem, de modo mais enfático, o núcleo familiar, estão Jogo da memória, de Laura Bergallo, em que uma família de ascendência italiana, particularmente o garoto Lucca, precisa enfrentar a doença do avô, Pietro, que sofre de Alzheimer. Em meio à trama, sobressaem cenas como almoços em família e retomadas históricas da imigração da família de classe média, que, diante de sua limitação econômica, precisa cotizar-se para enviar o pai em viagem à Itália.

Ainda no ambiente familiar de classe média, situa-se a história de Pedro, um garoto de I4 anos que perde o pai e a mãe (professora de literatura), em $A$ distância das coisas, de Flávio Carneiro. Tutelado pelo tio, o garoto é proibido de visitar o túmulo da mãe, o que o leva a buscar respostas para o comportamento do tio, entrando, assim, em um processo de amadurecimento emocional.

Em Um sonho no caroço de abacate, de Moacyr Scliar, as famílias de Mardoqueu, um garoto judeu, e de Carlos, um jovem negro, passam a se relacionar, pondo em evidência questóes sobre preconceito e bullying na escola.

Em O mundo de Camila, de Márcia do Canto, a família constitui o núcleo dramático central, em que os novos arranjos familiares são apresentados pela narradora, a garota Camila, que convive com tios homossexuais, pais divorciados e meios-irmãos.

Retratando ainda aspectos da família de classe média de um modo menos ou mais enfático, elencam-se as narrativas Tá falando grego, de Ricardo Hofstetter, Antes que o mundo acabe, de Marcelo Carneiro da Cunha, Isso ninguém me tira, de Ana Maria Machado, $O$ outro passo da dança e Um na estrada, ambos de Caio Riter, Pó de Parede, de Carol Bensimon, e O enigma de Iracema, de Rosana Rios.

Ainda atestando a centralidade da família nas tramas, destaca-se o fato de que os papéis afetivos desempenhados pelos personagens são os de filho (7I de 235 ocorrências), irmão/ã (22), mãe 
(20), pai (I8) ou parentes (I8), contrapondo-se personagens que náo integram as relaçóes familiares, como amigos (83), ou personagens sem nenhum vínculo familiar (34). Enfim, o que se nota é que, numa somatória, as relaçóes familiares aparecem em maior frequência (com 149 ocorrências) do que as relaçôes não familiares (II7).

Em meio à configuração social da cidade, que, no caso do corpus, é marcadamente familiar e de classe média, sobrelevam-se os dramas adolescentes. Fazendo coro com a tradição da literatura juvenil, em que se destacam as narrativas em forma de bildungsroman ou romances de formação, o universo adolescente é amplamente tematizado no corpus, de modo a ressaltar formas de aprendizado de vida e amadurecimento, favorecendo valores morais que se baseiam na compreensão das relaçóes humanas, na tolerância e na crença na resolução reflexiva dos conflitos pessoais. Essa centralidade da vida adolescente é atestada pelo número de personagens adolescentes/jovens presentes no corpus $(32,7 \%$, ou 77 ocorrências), superior ao de outras faixas etárias (adultos, 30,2\%, e crianças, $14,9 \%)$.

Com frequência, o drama adolescente se situa justamente em relação à família, seja pelas relaçôes difíceis com adultos problemáticos (alcoolismo, negligência, intransigência) ou pela falta dessas mesmas relaçóes, no caso de ausência ou abandono dos pais. São bons exemplos: Fala comigo, pai, de Júlio Emílio Braz; O outro passo da dança, de Caio Riter; A primeira vez que vi meu pai, de Márcia Leite; Pão feito em casa, de Rosana Rios; Um na estrada, de Caio Riter; e $A$ distância das coisas, de Flávio Carneiro. Em outros casos, associados aos problemas familiares, os adolescentes precisam superar conflitos internos gerados por situaçôes da própria vida e que os levarão a formas de maturação, como é o caso de Tuna, em Fala comigo, Pai; de Gabi, em Isso ninguém me tira; de Maria, em $A$ mocinha do mercado central; de Pedro, em 
A distância das coisas. Nesses textos, prevalece a ideia de que as pessoas podem avaliar seus problemas, verbalizá-los e buscar formas conciliatórias entre seus valores internos e o mundo circundante, perfazendo um caminho na direção da tolerância, da busca pela felicidade, da autonomia e da aceitação de si mesmo. A análise dos desfechos das narrativas corrobora essas afirmaçóes, já que 42,I\% dos personagens concluem sua trajetória numa situação de equilíbrio positivo, sendo que, analisadas essas situaçóes positivas, $24,7 \%$ referiam-se a resoluçóes de problemas/conflitos; $15,3 \%$, a conhecimento de si mesmo; e I3,6\%, a conhecimento de mundo.

Se o mundo retratado é o da cidade, focalizando a família de classe média e, nessa, a vida adolescente, o que é possível dizer sobre a cor e os gêneros representados no corpus? Certamente, trata-se de um mundo muito mais masculino do que feminino: das 235 personagens, 197 são homens e apenas 92 são mulheres. Muito embora se tenha observado no corpus aumento na autoria feminina, a questão dos gêneros ainda aponta para desigualdades: as mulheres carecem ainda de uma representação mais significativa, já que a presença dos homens é mais do que 50\% superior à de mulheres. Quando observados os papéis desempenhados na trama, o protagonismo masculino aparece em $60 \%$ dos casos dos 75 personagens que desempenharam papéis preponderantes, ao passo que os papéis femininos abarcam apenas $38 \%$.

A atuação feminina também aparece fragilizada quando se analisam as questôes de inserçáo no mundo do trabalho. Dos 63 personagens que têm trabalho formal, apenas $22(34,9 \%)$ são mulheres, enquanto quarenta $(63,5 \%)$ são homens. Essa representação oblíqua das relaçóes de gênero no mundo do trabalho pode ser observada nas profissóes mencionadas para homens e mulheres: foram arroladas 54 profissóes diferentes para homens e apenas i8 para mulheres, sendo que, no caso dos homens, as profissóes com maior ocorrência foram estudante, surfista, detetive, professor, ad- 
vogado, comerciante, empresário e agricultor, ocupaçôes de maior relevância social e econômica, ao passo que, no caso das mulheres, observaram-se profissóes de estudante, professora, dona de casa, aposentada, dona de pensão e escritora, fatos que evidenciam um imaginário sobre a mulher e sobre o trabalho realizado que muito se distancia da realidade social brasileira, na qual as mulheres não só têm maior escolaridade, como também representam um grande contingente de trabalhadoras em todos os campos.

Ainda no que diz respeito à discussão dos gêneros, é importante destacar que a pesquisa sobre a orientaçáo sexual das personagens apontou para a representaçáo maciça de uma afetividade heterossexual, com a ocorrência de apenas um caso de homoafetividade em personagem secundário, o que atesta que, mesmo em tempos de emergência de minorias, a literatura juvenil brasileira ainda vê os temas ligados à sexualidade como não apropriados aos leitores mirins, além de se alinhar a uma perspectiva ainda convencional e pouco problematizadora da questáo, o que também se comprova pelo fato de as práticas sexuais não serem mencionadas ou serem inexistentes ou até mesmo raras na vida dos personagens de todas as faixas etárias estudadas.

A homogeneidade da paisagem da grande cidade, que se descortina no corpus, contudo, não se refere apenas à preponderância do universo masculino em face às difíceis relaçóes de gênero, mas também à adoção de suas cores: $80 \%$ das personagens são brancas (I88 ocorrências), 22\% são pardos e amarelos (cinco), 7,2\% são negras (I7 ocorrências) e os índios são absolutamente ausentes. Tais dados evidenciam grandes lacunas no corpus estudado. Os personagens em que não foi possível inferir dados sobre a cor totalizam 9,8\%. Ao observar as questôes de pertença social, sexual, etária e étnica, os dados até aqui apresentados parecem contrapor-se à ideia de cidade moderna como locus de heterogeneidade e de 
disputas sociais e culturais, na perspectiva apontada por Fortuna e Silva (20II):

A cidade de hoje é marcada por uma cultura de fracturas e distâncias que a distingue de uma outra qualquer comunidade regida por princípios de partilha, comunhão de interesses e equidade social. Não se tratando de uma cultura de consagração da harmonia ou do consenso social, estipula condiçóes desiguais de acesso a direitos e revela uma cidadania disputada, objecto de conflitos sociais e políticos dispersos. Como qualquer entidade cuja unidade resulta da fragmentação dos seus elementos, a cidade e a cultura urbana são realidades incoerentes, recheadas de subcidades e subculturas (p. 432).

Ao elegerem o mundo da classe média e os conflitos adolescentes, predominantemente de homens brancos, heterossexuais e inseridos na grande metrópole, as narrativas tendem a uma representação homogênea da cidade contemporânea só ameaçada quando se observam as poucas exceçóes que refletem algumas das "fracturas" antes aludidas. Essas exceçóes é que tingirão de cores mais fortes as histórias e permitiráo que se matize a perspectiva social vivida das personagens, trazendo à tona, ainda que de um modo pouco recorrente, a cidadania disputada de que fala Fortuna.

Nesse sentido, é isso que se nota nos livros $O$ livreiro do Alemão, de Otávio Júnior, narrativa romanceada de um jovem negro que desenvolve um programa de estímulo à leitura na favela do Alemão, no Rio de Janeiro; em $O$ homão e o menininho, de Luís Pimentel, em que as relaçóes entre filhos e pais ou adultos e crianças extremamente pobres são descritas numa novela bem-humorada cujos elementos de continuidade, típicos do gênero, são exatamente os espaços de periferia e os personagens miseráveis; no excelente Quarto de despejo, de Carolina Maria de Jesus, e em sua 
história consagrada de uma mulher negra e favelada que se torna escritora; em Um sonho no caroço do abacate, de Moacyr Scliar, em que um jovem judeu de classe média se enamora de uma moça negra de elite; em Sortes de Villamor, de Nilma Lacerda, que narra a história da velha negra Ismê Catureba, que acolhia crianças negras órfẫs na Salvador do século XIX; ou no simbólico Tem um morcego no meu pombal, de Moisés Liporage, que fala do preconceito racial das famílias do morcego negro Samuca, que se apaixona pela pombinha branca Didi.

Essas "fracturas" também estão presentes nas relaçôes preconceituosas discutidas em $O$ golem do Bom Retiro, de Mário Teixeira, e na violência de $O$ outro passo da dança, de Caio Riter. Nessas narrativas, é possível ouvir, ainda que timidamente, as fraturas da hegemonia da classe média e os sussurros de algumas "subcidades" e suas "subcidadanias", habitadas, sobretudo, por negros, mulatos e pobres. Nesses textos, que náo ultrapassam $15 \%$ do corpus, o espaço urbano que se delineia é outro: favelas, ruas em que trabalham crianças vendedoras de miudezas e feiras livres, como em alguns episódios da novela $O$ homáo e o menininho:

De segunda a sábado o carrinho era o ganha-pão de Bidu, com ele fazendo carretos nas feiras-livres, transportando frutas, legumes, folhas e até peixes para os moradores das imediaçôes (Pimentel, 20IO, p. 7).

[...]

A menina estendeu a mão para o ônibus em Brás de Pina e entrou pela porta traseira [...]. Desceu na estaçẫo que fica ao lado do cinema e reabriu a caixa de goiabada no sinal. Vendia a vinte centavos cada; três por cinquenta (Idem, p. 25).

Também estáo presentes nos barracos de favela, desprovidos de cidadania, justiça, cultura, dignidade e dinheiro, mas cerca- 
dos por violência e insegurança, como em $O$ livreiro do Alemão, de Otávio Júnior, ou Quarto de Despejo, de Carolina Maria de Jesus:

Amanheceu chovendo. Tenho só treis (sic) cruzeiros porque emprestei 5 para Leila ir buscar a filha no hospital. Estou desorientada, sem saber o que iniciar. Quero escrever, quero trabalhar, quero lavar roupa. Estou com frio. E náo tenho sapato para calçar. Os sapatos dos meninos estão furados [...]. Todas as crianças de favela sabem como é corpo de uma mulher. Porque, quando os casais que se embriagam brigam, a mulher, para não apanhar, sai nua para a rua (Jesus, 20I3, p. 45).

Acho que poucos ouviram o primeiro tiro, mas o estampido me deixou preocupado. Os tiros foram se sucedendo e as crianças começaram a ficar apavoradas. Olhavam, assustadas, para os lados e pela janela (Júnior, 20II, p. IO).

[...]

Naquele mesmo dia, no começo da noite, uma chuva muito forte acabou com a luz no morro e em nossa casa. Minha mãe acendeu duas velas, o suficiente para iluminar o único cômodo que servia de sala, quarto e cozinha (Idem, p. 22).

Não fossem esses poucos livros dissonantes em relação à homogeneidade presente no corpus, a cidade grande, desenhada nas linhas das narrativas aqui estudadas, seria bem pouco plural em relação à representação da sociedade brasileira. Segundo Fortuna e Silva (20I4), "a cidade é sinônimo de heterogeneidade social e cultural, de relativização de perspectivas e de diversidade de estilos e de comportamentos sociais" (p. 423). Por ser arena de conflitos, a preservação dessas diferenças e das identidades variadas que podem emergir na cidade acaba sendo influenciada pela negociação e pelo contato com o diverso, o que pressupóe arranjos políticos, 
culturais e disputas pela cidadania. Entra-se, assim, no terreno do ideológico, em que a linguagem, sobretudo aquela do mundo letrado - a língua escrita -, constitui elemento de legitimação.

J. Culler (I999), ao discutir o aspecto performativo da linguagem a partir das teorias de J. L. Austin, afirma que a linguagem não é apenas referencial (representa ou nomeia coisas), mas também performativa, no sentido de criar a própria realidade, de fazer uma realidade existir: "Ela é performativa no sentido de que não apenas transmite informação, mas realiza atos através de sua repetição de práticas discursivas ou de maneiras de fazer as coisas estabelecidas" (p. 99). Por essa razão, para o autor, a literatura "não é uma pseudodeclaração frívola, mas assume seu lugar entre os atos de linguagem que transformam o mundo, criando as coisas que nomeia" (Idem, p. 97).

Ora, se a linguagem e, por extensão, a literatura (sobretudo os textos literários socialmente valorizados, como aqueles aqui discutidos) podem contribuir para a construçáo de diferente(s) realidade(s)/identidades, nada mais desejável que reflitam a pluralidade das perspectivas sociais, fazendo com que possam vir ao centro da cultura e da sociedade todos aqueles que ainda estáo nas margens, questionando, inclusive, as formas estereotipadas com que alguns grupos têm sido historicamente representados, tanto na literatura como no mundo das práticas sociais efetivas.

É evidente que náo se espera que a literatura, na qualidade de criaçáo do imaginário por meio do estético, seja mera cópia da realidade e dos seres. Se assim fosse, teriam valor para o leitor apenas os textos que falassem de sua vivência imediata. Tendo como uma de suas finalidades a expansão do universo cognitivo, emocional e social do jovem, a literatura juvenil brasileira contemporânea contribuiria com mais densidade para a emancipação do leitor na medida em que pudesse incorporar realidades múltiplas, confrontando a diversidade étnica, econômica, racial, sexual e so- 
cial que cerca o adolescente e que constitui o mundo urbano, no qual as sociedades contemporâneas, inescapavelmente, estão inseridas. Contribuiria, assim, para sua passagem ao universo adulto de uma forma que pudesse observar e talvez até mesmo questionar as amarras ideológicas com que o mundo por ele desejado - o dos adultos - tem sido construído.

\section{Referências}

ARISTÓTELES et al. A poética clássica. São Paulo: Cultrix, I98I.

CANDIDO, Antonio. "A personagem do romance". In ROSENFELD, A. et al. A personagem de fiç̧ão. São Paulo: Perspectiva, 1992.

CHARTIER, Roger. A história cultural. Rio de Janeiro: Bertrand, I990.

COLOMER, Teresa. A formação do leitor literário: literatura infantil e juvenil atual. Trad. de Laura Sandroni. São Paulo: Global, 2003.

COMPAGNON, Antoine. O demônio da teoria: literatura e senso comum. Belo Horizonte: UFMG, 2006.

CULLER, Jhonatan. "Linguagem performativa”. In Teoria literária: uma introdução. São Paulo: Beca Produções Culturais Ltda, 1999, pp. 95-Io6.

DALCASTAGNÈ, Regina. "A personagem do romance brasileiro contemporâneo: 1990-2004". Cronópios, pp. I-38, maio de 2007. Disponível em: $<$ http://cronopios.com.br/anexos/regina_dalcastagne.swf>. Acesso em o2 mar. 2012.

. "Vozes nas sombras: representação e legitimidade na narrativa contemporânea”. In Ver e imaginar o outro: alteridade, desigualdade, violência na literatura brasileira contemporânea. Vinhedo: Horizonte, 2008, pp. 78-I07.

FORTUNA, Carlos e SILVA, Augusto Santos. "A cidade do lado da cultura: espacialidades sociais e modalidades de intermediação cultural”. In SOUZA SANTOS, Boaventura (org.). A globalização e as ciências sociais. São Paulo: Cortez, 20II, pp. 419-68.

GOLDMANN, Lucien. Sociologia do romance. Trad. de Álvaro Cabral. São Paulo: Paz e Terra, I990. 
INSTITUTO PRÓ-LIVRO. "Fomento e acesso ao livro. Retratos da leitura (2OII, 20I3)”. Disponível em: http://prolivro.org.br/home/index.php/atuacao/25-projetos/pesquisas/39oo-pesquisa-retratos-da-leitura-no-brasil-48>. Acesso em 07 abr. 2015.

LAJOLO, Marisa e ZILBERMAN, Regina. Literatura infantil brasileira: histórias e histórias. São Paulo: Ática, 1985.

PECHMAN, Robert. "Desconstruindo a cidade: cenários para a nova literatura urbana”. In KUSTER, Eliana e PECHMAN, Robert (orgs.). O chamado da cidade: ensaios sobre a urbanidade. Belo Horizonte: Ed. da UFMG, 20I4, pp. 89-IOI.

ROSEMBERG, Fúlvia. Literatura infantil e ideologia. São Paulo: Global Editora, 1985 . 


\title{
8 \\ Infância e literatura: entre conceitos, palavras e imagen ${ }^{1}$
}

\author{
Patrícia Corsino
}

\begin{abstract}
[...] tudo é uma Literatura só. A dificuldade está em delimitar o que se considera como especialmente no âmbito infantil. São as crianças, na verdade, que o delimitam, com sua preferência. Costuma-se classificar como Literatura Infantil o que para elas se escreve. Seria mais acertado, talvez, assim classificar o que elas leem com utilidade e prazer. Não haveria, pois, uma Literatura Infantil a priori, mas a posteriori.
\end{abstract}

Cecília Meireles

Cecília Meireles, nos anos I950, questiona-se sobre o que poderia ser delimitado como literatura infantil. Propóe, assim, que o limite fosse dado pelas próprias crianças. Coloca, pois, nas crianças a liberdade de escolha. E isso acaba por interpelar os adultos diante da grande produção editorial voltada ao público infantil. $\mathrm{O}$ que seria literatura infantil? $\mathrm{O}$ que se pode considerar literatura? A literatura como arte vale-se de limites etários definidos? Haveria uma arte infantil?

Este artigo tem por objetivo refletir sobre infância e literatura na perspectiva de compreender a literatura infantil como arte e o livro infantil contemporâneo como espaço de articulação entre três campos: a arte da palavra/literatura, as artes visuais e a arte de design gráfico editorial.

\footnotetext{
I. Texto publicado na revista Teias, v. I6, n. 40, 20I5, Proped, UERJ. Disponível em: http://www. periodicos.proped.pro. Atualizado para este livro.
} 
Inicialmente, discutem-se os conceitos de infância e literatura, tomando como pressuposto o fato de que são historicamente produzidos e que a literatura infantil está em articulação com ambos os conceitos. Em um segundo momento, aborda literatura como arte e sua especificidade, trazendo o livro Raposa, de Margaret Wild e Ron Brooks, para dialogar com as seis propostas de Italo Calvino (1990) e o direito à literatura defendido por Candido (20II). Finaliza refletindo sobre a consistência de que uma literatura-arte pode dar sentido à própria existência.

\section{I Infância e literatura}

Infância e literatura são dois conceitos que foram inventados e reinventados ao longo do tempo, variando conforme a época, o lugar, os grupos sociais e seus valores. A literatura adjetivada como infantil é produzida no seio de uma cultura que define o que é ou năo literatura e também o que é ou não infantil ou próprio das/para as crianças.

A infância como uma categoria social é uma construção da modernidade. O que hoje entendemos como infância é um conceito que foi historicamente elaborado no mundo ocidental. Sarmento (20II) aponta quatro eixos estruturantes desse processo: i) a família nuclear, que, gradativamente, foi substituindo os outros agrupamentos familiares e foi se constituindo como um lugar de vinculação e pertença afetiva da criança; ii) a escola pública, criada no século XVIII, que se constituiu como um espaço institucional de crianças; iii) a construção de um conjunto de saberes institucionalizados sobre a "criança normal", que institui a ideia de criança como ser biopsicológico em processo de maturação e crescimento; iv) a administração simbólica, com a definição implícita e explícita de regras de inclusão, interdição, compulsão e reconhecimento das crianças. Assim, "o conjunto de injunçóes decorren- 
tes desses quatro pilares associados contribuiu desde há cerca de dois séculos e meio para consignar à criança um lugar social próprio, cujo desenho e cuja topografia correspondem à representação social dominante da infância” (p. 586). As crianças e a infância passaram a ser objeto de estudo de diferentes campos científicos, os quais foram aprofundando e ampliando os conhecimentos, ao lhes conferirem cientificidade.

Assim, no final do século XIX e no início do século XX, em toda parte do mundo ocidental, a infância era tanto um princípio social como um fato social (Postman, 1999, p.65), mas os conhecimentos começaram a ser sistematizados sob a lógica de construção do homem moderno, cujo "programa do esclarecimento era o desencantamento do mundo e cuja meta era dissolver os mitos e substituir a imaginação pelo saber" (Adorno e Horkeimer, 1985, p.19). A ciência, vista como verdade, teria a responsabilidade de explicar, organizar e catalogar o "real" e o "ser" em sua totalidade. A ciência e a racionalidade trouxeram a ideia de progresso como domínio do homem sobre a natureza, de evolução, de causa e efeito, de linearidade temporal, de controle e previsibilidade. Nesse projeto, a preocupação inicial com a educação das crianças teve por objetivo a construção do homem de amanhã, cuja maturidade seria identificada com a chegada à razão. A moralização e a disciplinarização impostas às crianças por pais e mestres faziam parte do projeto de abreviar o tempo da ignorância e apressar uma etapa da vida vista como menor, transitória e passageira.

$\mathrm{Na}$ perspectiva do progresso, o desenvolvimento humano foi concebido como uma sucessão de etapas ou estágios. A noção de desenvolvimento assume características próximas e derivadas da noção biológica de evolução, ou seja, da transformação de formas de se comportar e de pensar ao longo de um tempo linear e cumulativo, em que o homem adulto é o ponto de chegada. Ao descrever e organizar o desenvolvimento infantil em etapas, perío- 
dos ou fases, esse enfoque mostra cientificamente o processo de maturação da criança. O elenco de características próprias de cada momento torna-se, então, o parâmetro para organizar os conteúdos e as atividades consideradas próprias para cada faixa etária ou série escolar, enquadrar as crianças em comportamentos esperados, bem como avaliá-las e classificá-las segundo as etapas que já percorreram ou não.

Com um lugar social constituído, a infância passa a ter produçôes culturais distintas das dos adultos, e essas também passam a se valer dos estudos sobre o desenvolvimento infantil para atender a um público cada vez mais setorizado. Livros, brinquedos, filmes, entre outros, são produzidos e recomendados para determinada faixa etária ou série escolar, como se a infância fosse um conceito abstrato, genérico e universal, e como se a idade das crianças, em que pesem os contextos culturais, étnicos, religiosos e classes sociais, fosse uma categoria homogênea. As crianças são descontextualizadas de suas condiçôes sócio-históricas e culturais e afetivo-volitivas, tornando-se um nicho de mercado cada vez mais promissor. Souza (1996) adverte para esse processo crescente, que coloca a criança a serviço das imposiçóes de uma racionalidade "modeladora das formas específicas de subjetividade, cuja matriz é a situação histórica e social do homem moderno, submerso nas exigências de um ideal de sujeito produtivo e consumidor" (p. 46).

Para Castro (2013, p.I7), a cronologia do curso da vida torna-se um aspecto relevante, especialmente nas sociedades industriais modernas, em que a ordenação dos momentos da biografia direciona as oportunidades de participação dos indivíduos no mundo do trabalho, e a faixa etária serviria para a elaboração de um conjunto de normas de comportamento, com vistas a definir seu lugar social. Nesse cenário, a concepção de criança apresentou-se como uma fase de preparaçáo para a vida produtiva, determinan- 
do "um dever-ser desses sujeitos como indivíduos ainda não prontos, imaturos e ainda não socializados para participar integralmente da vida em sociedade" (Idem, ibidem). Afirma também:

Assim, a idade constituiu não apenas o índice que serviu para denotar a diferenciação [entre a infância e a vida adulta], mas o princípio temporal que a organiza. Ainda que se critique o uso essencialista dessas noções, as definiçóes sobre o que é ser criança permanecem até hoje atreladas à lógica evolutiva/diferencialista do curso da vida humana, principalmente se considerarmos o seu uso nos campos do direito e da educação. Mesmo admitindo-se deslocamentos em relação à concepção linear, cumulativa e progressista do ciclo da vida humana, parece difícil abrir mão da noção de preparação enraizada na percepção das novas geraçôes como "novatos" que chegam ao mundo que a eles preexiste (Idem, pp. 17-8).

Walter Benjamin (I993a e I993b) critica a concepção evolucionista de história como um tempo contínuo que caminha irremediavelmente para o futuro, que, em nome do progresso, descarta o passado, considerando-o velho ou obsoleto. Ao analisar criticamente a modernidade, relaciona o progresso e o desenvolvimento ao empobrecimento da experiência humana e à alienaçáo da linguagem.

Nessa perspectiva, Benjamin (I993b) traz outras possibilidades para se pensarem o tempo histórico e também as crianças. Em seus escritos "Rua de mão única", "Infância berlinense" e "Imagem e pensamento", não se limita a trazer recordaçôes de sua infância, mas, ao dar voz ao menino, traz a forma como ele via e sentia o mundo, falando também de um momento histórico e de uma sociedade. Nesse contexto, tal objetividade permite ao leitor o despertar de sua própria infância, quebrando-se, nessa rememoração, a ideia de tempo linear e ampliando-se o sentido 
de coletividade. O menino Walter fala de si, de seu momento histórico e de sua inserção social e cultural, trazendo uma história que é, ao mesmo tempo, individual e coletiva, história que pode ser continuada e ressignificada dentro de cada um de nós a partir da experiência de ser criança. História que também continua na experiência de ser criança em diferentes tempos e espaços. Os textos e fragmentos do autor, como uma mônada que contém na parte a totalidade, dáo voz à criança totalmente inserida na história, integrante da cultura e produtora de cultura. Benjamin, assim, recupera o mundo da cultura dos pais e, ao mesmo tempo, recupera a maneira de ver da criança, sua sensibilidade, seus hábitos, desejos, afetos e valores, evidenciando a agência ${ }^{2}$ infantil com toda a sua competência e a capacidade de agir e transformar.

Esse deslocamento na forma de pensar a infância antecipa o que vem sendo reivindicado pelos estudos contemporâneos, especialmente os da sociologia da infância, que trazem a noção de competência como distintiva de uma nova posição da criança no mundo, caracterizando-se pela capacidade de "co-construção da própria infância, como também da sociedade. Esse paradigma da competência faz das crianças agentes sociais plenos, cujo agir modifica as estruturas sociais em que se encontram, dando-lhes outros sentidos (Castro, 2013, p. I8).

Ainda que o paradigma da competência e da agência infantil busque seu espaço nas sociedades contemporâneas, como Castro elucida, parece difícil, ainda hoje, abrir mão da ideia de preparo das crianças. Náo se pode afirmar um consenso sobre essas concepçôes e que elas sejam universalmente aceitas. Assim, coexistem diferentes concepçôes de crianças e infâncias, que se apresentam, com frequência, de forma contraditória nos tempos e espaços em

2 Corsaro (20II) considera agentes aqueles que produzem a própria cultura, enquanto, simultaneamente, contribuem para a produção da sociedade, enquanto o termo agência [agency] diz respeito à ação de um agente e à açấo coletiva articulada com as transformaçōes sociais. 
que as crianças circulam, nos produtos e nos artefatos que portam e consomem, nos serviços e instituiçóes a elas direcionados. Desse modo, tanto a produçáo de literatura infantil como as formas de os adultos lerem para e com as crianças vão oscilando entre paradigmas distintos.

Também o conceito de literatura tem-se apresentado de formas diversas ao longo da história. Compagnon (2009), ao indagar o que seria literatura, chama a atenção para o fato de que o termo literatura data do início do século XIX. Anteriormente, literatura eram as inscriçóes, a escritura, a erudição ou o conhecimento das letras, o equivalente a cultura. No entanto, no sentido moderno de literatura, compreendem-se o romance, o teatro e a poesia, retornando-se à tríade pós-aristotélica dos gêneros épico, dramático e lírico. E, nessa veia, o critério de valor e a ideia de cânone, de grandes escritores, passaram a identificar a literatura com a literatura culta, excluindo tudo que fosse literatura popular, mas, como o sistema é dinâmico e cada nova obra movimenta o todo, operam-se novas configuraçóes e rearranjos da tradiçáo como totalidade. Assim, Compagnon argumenta que, após o estreitamento da literatura do século XIX, no século seguinte uma parte dos territórios perdidos foi novamente incorporada, e o termo literatura passou a ter novamente uma extensão mais ou menos vasta "dos clássicos escolares à história em quadrinhos, sendo difícil justificar sua ampliação contemporânea. O critério de valor que inclui tal texto não é em si mesmo literário nem teórico, mas ético, social, ideológico, de qualquer forma extraliterário" (Idem, p. 34).

Eagleton (2003), ao propor a mesma indagaçáo, questiona a ideia de literatura como uma categoria objetiva. Refuta a concepção de literatura como uma escrita imaginativa, como uma forma especial de linguagem em contraste com a linguagem comum, como algo sem finalidade prática imediata, trazendo também os julgamentos de valor como ponto fundamental para defini-la. Em 
outras palavras, valores que se referem não apenas ao gosto particular, mas também aos pressupostos pelos quais certos grupos sociais exercem e mantêm o poder sobre outros. Nessa perspectiva, considerar um texto literário ou não literário significa assumir um ponto de vista partilhado por um grupo que, por sua vez, tem suas concepçóes ideologicamente sustentadas.

É ainda Compagnon (20I2) que identifica quatro explicaçóes sobre o valor dado à literatura ao longo da história: i) na perspectiva clássica, a literatura seria um meio de instruir deleitando; ii) na perspectiva iluminista, a literatura seria um remédio para libertar os indivíduos de sua sujeição às autoridades, contestar a submissão ao poder e também um antídoto para a fragmentação da experiência subjetiva; iii) em um terceiro movimento, a literatura seria um remédio, mas não mais para os males da sociedade, e sim para a inadequação da língua, tornando os sujeitos mais inteligentes, por ensiná-los a não serem enganados pela língua: "Só a literatura trapaceando com a língua, trapaceando a língua, salvava a língua do poder da servidão" ( $\mathrm{p}$. 50, citando Barthes); iv) em um quarto momento, ocorre uma recusa a qualquer poder da literatura, que passa a ser entendida como um passatempo, "respiro" que estaria fora de compromisso instrumental ou de suplência - pedagógica, ideológica ou linguística. Assim, esses quatro movimentos situados pelo autor também coexistem e não se pode afirmar que sua adesão seja universal. Entretanto, apresentam concepçóes que conferiram e conferem - à literatura lugares ou valores sociais partilhados. Ocorrem permanências e recusas de posição.

A literatura infantil surge na injunção dos pilares que sustentaram a constituição da infância como uma categoria social. Aliando-se à família nuclear e à escola, tornou-se um caminho de moralização e ensino, lugar fértil para instruir as crianças divertindo. Os registros de contos de tradição oral, os quais eram exemplares 
não apenas para as crianças, foram os primeiros textos selecionados como leitura para e pelas crianças.

Para Benjamin (I993a), contudo, os contos de fadas, mesmo com cunho moralizante, podem ser considerados os primeiros conselheiros das crianças, por terem uma característica que os distingue dos textos meramente educativos: a cumplicidade da natureza com o homem e sua libertação do pesadelo mítico. É justamente essa possibilidade de o ouvinte/leitor dos contos de fadas vencer o mundo místico com astúcia e coragem que confere à moralizaçáo o status de conselho. A centralidade dessas narrativas na mensagem e no herói provoca o imaginário à continuidade da história pela ambiguidade que se abre no leitor, e não apenas nos fatos narrados. Nos contos de fadas, a voz autoritária do adulto sobre a criança se dilui nessa ambiguidade que se instaura, pois vencer o mito implica também a libertação do narrador cúmplice e partícipe de uma infância da própria humanidade.

Foi a partir do século XX, com a realizaçáo de pesquisas de cunho psicanalítico e pedagógico voltadas para a criança, que a linguagem dos textos infantis se desloca da mensagem para fazer prevalecer a função pedagógica. A literatura infantil passa, então, a ser confundida com a pedagogia. Dessa forma, a informação, e não exatamente o conselho, passa a ser predominante. $\mathrm{O}$ reflexo dessa concepçáo no texto aparece na forma como a narrativa é conduzida: é a voz de um adulto, que sabe e conhece, que transmite uma mensagem para um menor que recebe, compreende e copia.

Benjamin lança um olhar crítico para essas produçóes, que evidenciam a intenção de moralização e disciplinarização das crianças, e que apresentam um distanciamento do que as crianças são capazes de problematizar perante o mundo: 
Trata-se de um preconceito segundo o qual as crianças são seres tão diferentes de nós, com uma existência tão incomensurável à nossa, que precisamos ser particularmente inventivos se quisermos distraí-las. No entanto, nada é mais ocioso que a tentativa febril de produzir objetos - material ilustrativo, brinquedos ou livros - supostamente apropriados às crianças. [...] Em seu preconceito, eles não veem que a terra está cheia de substâncias puras e infalsificáveis, capazes de despertar a atenção infantil (Benjamin, I993a, p. 237).

$\mathrm{O}$ autor considera ociosa a tentativa de os adultos produzirem objetos destinados às crianças conforme sua visão adultocêntrica, pois as crianças, diante das produçôes culturais, criam, alteram e transformam. Para Benjamin, as cores, a atmosfera onírica dos livros, por exemplo, convidam as crianças a um diálogo para além do texto. Assim, ficam mais envolvidas e interessadas com o fantástico, com as ilustrações, do que propriamente com a função moralizante dos textos. Benjamim faz uma critica ácida aos pedagogos que têm como tarefa inculcar em crianças e jovens princípios e valores imperativos, questionando a pedagogia burguesa ao afirmar: "a burguesia vê sua prole enquanto herdeiros; mas, aos deserdados, enquanto apoio, vingadores ou libertadores" (Benjamin, I984, p. 89).

Para Benjamin (I993a), a literatura produzida em sua época era "uma criação sem raízes, por onde circula uma seiva melancólica, que nasceu do solo de um preconceito inteiramente moderno" (p. 237), preconceito relacionado à concepção de infância baseada na falta, na incompletude, na minoridade, na imaturidade, na improdutividade, na dependência em relação ao adulto. No entanto, tal concepção também foi questionada ao longo dos anos que nos separam de Benjamin.

São muitas as tensôes e as contradiçôes subjacentes às obras destinadas às crianças. Hoje, há um número significativo de livros 
que instigam as crianças, fazendo com que se desloquem, se surpreendam e se emocionem. Existem autores, ilustradores e editores que apostam na capacidade das crianças, que sabem quanto elas são indomáveis em sua forma peculiar de significar os textos; que estáo atentos à qualidade do texto verbal, das ilustraçôes, da abordagem dialógica dos temas que perpassam a vida, e não apenas a um suposto universo infantil. Tais autores conseguem colocar no mercado obras que são fruto de uma visão crítica de infância e de luta, na contramão de um empobrecimento da linguagem. Todavia, há aqueles que insistem em manter a tutela e em não fazer da tradição algo produtivo e transformador. Há outros ainda que se rendem às facilidades da cultura de massa, ao empobrecimento da experiência humana e à alienação de uma linguagem rasa e das abordagens banais.

A escolarização, que se instituiu como um direito de todas as crianças à educação, foi e tem sido um nicho do mercado editorial que produz toda a sorte de livros infantis: didáticos, informativos, não ficcionais, de autoajuda, brinquedo, literários, entre outros. Muitas são as categorias possíveis e seus hibridismos. Neste texto, nossa proposta consiste em discutir os livros infantis literários. Mas, em que pesem a extensão dessa categoria e as divergências de concepçáo, para tecer nosso ponto de vista, tomamos como pressuposto a literatura como arte, independentemente da classificação - se infantil ou não - e as teorias de Bakhtin e de seu círculo (Voloshínov, 1926), bem como as de Vigostski (200I), que também abordam a literatura nessa perspectiva.

Bakhtin (1926) - e o Círculo de Bakhtin/Voloshínov - entende a arte como um elemento eminentemente social:

O meio social extra-artístico, afetando de fora a arte, encontra resposta direta e intrínseca dentro dela. Não se trata de um elemento estranho afetando outro, mas de uma formação so- 
cial, o estético, tal como o jurídico ou o cognitivo, é apenas uma variedade do social (p. I).

$\mathrm{O}$ autor faz uma crítica a dois pontos de vista.

$\mathrm{O}$ primeiro, que define a fetichização da obra artística como artefato, uma atitude que restringe a obra de arte a si própria. No caso da literatura, o verbal não como um fenômeno sociológico, mas como um fenômeno linguístico abstrato, compreendido independentemente da situação social que o engendra.

$\mathrm{O}$ segundo, que restringe a arte ao estudo da psique do criador ou do contemplador, resumindo-a às experiências da pessoa contemplando/lendo ou da pessoa criando/escrevendo.

Assim, para o autor, ambos os pontos de vista pecam pela tentativa de descobrir o todo na parte: "O artístico é uma forma especial de inter-relação entre criador e contemplador fixada em uma obra de arte" (Idem, p. 3). A arte se torna arte na interação entre criador e contemplador; fora disso, é um mero artefato ou exercício linguístico.

Bakhtin (1926) - e o Círculo de Bakhtin/Voloshínov — sustenta a ideia de que a forma de um enunciado artístico é a expressão direta de avaliaçôes sociais. Julgamentos de valor determinam a seleção de palavras do autor, bem como a respectiva recepção dessa seleção por ouvinte/leitor. Para o autor, cada expressão selecionada é um ato avaliativo orientado em duas direçôes — na direção do ouvinte e na direção do herói: "Ouvinte e herói são participantes constantes do evento criativo, o qual não deixa de ser, nem por um instante, um evento de comunicação viva envolvendo todos os três" (Idem, p. II). Assim, embora a forma esteja fixada num material, a significação da forma tem relação não com o material, mas com o conteúdo. A seleção do conteúdo e a seleção da forma constituem um ato único, estabelecendo a posição básica do criador; e, nesse ato, uma e a mes- 
ma avaliação social encontra expressão. $\mathrm{O}$ artista, pela mediação da forma artística, assume posiçáo ativa no que diz respeito ao conteúdo. Nesse sentido, forma e conteúdo são indissociáveis e marcam a posição do criador. Assim, autor, herói e ouvinte/leitor são elementos constitutivos da obra, determinantes da forma e do estilo desde o seu interior.

O ouvinte/leitor é um participante imanente, um fator intrínseco da obra, e não coincide com o público-leitor, localizado fora da obra, cujos gostos e exigências podem ser conscientemente levados em conta. No entanto, para Bakhtin, "se o fato de levar conscientemente em conta o público-leitor vem ocupar uma posição de alguma importância na criatividade do poeta, essa criatividade inevitavelmente perde sua pureza artística e se degrada a um nível social mais baixo" (Idem, p. I2). O ouvinte/leitor não pode ser confundido com uma pessoa real. O interesse externo do autor aponta para a perda do ouvinte/leitor imanente e para a cisáo do todo social, determinando, intrinsecamente, os julgamentos de valor e a forma artística de seus enunciados poéticos. Para o filósofo da linguagem, a forma de um enunciado artístico é determinada pelos seguintes elementos: o valor hierárquico do herói ou evento funcionando como o conteúdo do enunciado; seu grau de proximidade com o autor; e o ouvinte e sua inter-relaçáo com o autor, de um lado, e com o herói, de outro. A concepçáo de infância do autor é, portanto, fator determinante para a obra. $\mathrm{Na} \mathrm{li-}$ teratura infantil, são considerados autores o escritor, o ilustrador e o designer gráfico, pois todos eles imprimem suas marcas na articulação entre os discursos verbal e visual.

A concepção bakhtiniana de arte provoca, assim, algumas questôes quanto às obras de literatura infantil. Ao analisar cada produção, cabe indagar: como se estabelece a relação entre autores, herói e ouvinte/leitor? Com que julgamento de valor os autores constroem o herói em correlação com o ouvinte/leitor infantil? 
Vigotski (200I) tece algumas considerações sobre a arte que dialogam com as discussóes de Bakhtin. Seu enfoque estético tem fundamento psicossocial, ou seja, a arte deve combinar as vivências individuais com a recepção do produto estético percebido como produto social e cultural. Bezerra (200I), na introdução do livro Psicologia da arte, de Vigotski, afirma: "A arte é o social em nós. Mesmo que o seu efeito se registre em um indivíduo à parte, isso não nos autoriza a afirmar que as raízes e a essência da arte sejam individuais, assim como seria ingênuo imaginar o social apenas como coletivo "(p. xii). Além dessa dimensão social, Vigotski destaca a importância da emoção na arte tanto na produção da obra como na apreciação. A arte deve ser capaz de abordar emoçôes contraditórias, de modo a construir um deslocamento, um "curto-circuito emocional" no apreciador.

Vigotski e Bakhtin entendem o artístico nas inter-relações entre criador, contemplador e obra. Cada um desses três elementos é constitutivamente social. O social expresso na própria obra e no que ela desencadeia no outro e o social constitutivo tanto do artista-criador como do contemplador-apreciador: sujeitos históricos, socialmente situados.

\subsection{Literatura infantil: artes em convergência}

A literatura, como toda arte, como assinala textualmente o poeta Fernando Pessoa, é a "confissão de que a vida não basta". E a vida não basta para adultos e crianças. Partimos, então, do seguinte ponto: tratar a literatura infantil contemporânea naquilo que "não basta".

Elegemos uma obra para tecer nossos argumentos, entendendo-a como mônada, parte que dialeticamente contém o todo. Uma obra de literatura infantil que, em sua singularidade, reflete "tudo em si e está refletida em tudo" - um elemento cultural que 
participa da cultura humana (Bakhtin, I998, s.p.). Trata-se do livro Raposa, de Margaret Wild, com ilustraçóes de Ron Brooks e tradução de Gilda Aquino.

A escolha para a análise dessa obra decorreu dos seguintes critérios: i) qualidade reconhecida por um grupo de especialistas recebeu o Prêmio da Fundaçáo Nacional do Livro Infantil e Juvenil na categoria tradução e adaptação em 2006 e foi selecionada pelo PNBE-2006 para os anos iniciais do ensino fundamental; ii) pertence a um gênero clássico - a fábula - com um viés contemporâneo, o que favorece comparaçóes e referências; iii) é um livro classificado como picturebook, ou livro ilustrado, cuja principal característica é a interdiscursividade que se estabelece entre o discurso verbal e o visual. Nesse contexto, embora Raposa não seja o tipo de livro que surgiu apenas na atualidade, tem estado cada vez mais presente nas produçôes contemporâneas; iv) há registros de evento de pesquisa de campo realizada em uma turma de crianças de 5 a 6 anos, com a leitura desse livro, que compóe o corpus de um dos estudos de caso da pesquisa "Infância, linguagem, escola: a leitura literária em questão", por nós coordenada e que resultou na dissertação de mestrado de Soares (20I4).

Nesse livro, como em muitos outros do gênero, as artes da palavra e a arte visual são interdependentes. Dessa maneira, é necessário ler e ver, pois tanto uma coisa como outra dizem algo. E a narrativa é conduzida pelas duas linguagens simultaneamente. Para Belmiro (20I2), é preciso "superar a dicotomia ver versus ler, adicionando ao ver o estatuto de ler alguma coisa, e, ao ler, as condiçóes de poder ver alguma coisa. O que nos une é o dizer, e isso solicita uma discursividade que recupera a presença dos interlocutores e seus atos de fala" (p. 127).

Calvino (1990), ao discutir o futuro da literatura no milênio em que vivemos, confia em que "há coisas que só a literatura com seus meios específicos nos pode dar" (p. II). Entendemos 
que esses meios específicos se articulam às considerações de Candido (20II), ao conceber a literatura como direito de todos e um bem incompressível, ou seja, indispensável ao ser humano. Mas quais seriam as qualidades, as especificidades da literatura? Calvino apresenta seis propostas que estendemos à literatura sem adjetivos: leveza, rapidez, exatidão, visibilidade, multiplicidade e consistência.

$\mathrm{Na}$ leveza, entre outras imagens, mitos e lendas, Calvino (I990) apresenta "o salto ágil e imprevisto do poeta-filósofo que sobreleva o peso do mundo, demonstrando que sua gravidade detém o segredo da leveza" (p. 34). A literatura daria a possibilidade do voo, não como devaneio ou fuga, mas como libertação. Seria a possibilidade de fabulação, que Candido (2OII) considera uma "manifestação universal de todos os homens em todos os tempos" (p. I76). Em outras palavras, seria na vigília o que o sonho é no sono, indispensável à pessoa humana.

A leveza do voo em literatura infantil, contudo, é frequentemente entendida como falta de consistência e densidade. Visão simplificada e/ou adocicada dos dramas humanos, como se a criança não participasse deles ou não os sofresse na própria pele. A leveza é o contraponto do peso. A literatura, ao trazer ao leitor questóes da vida, permite o encontro do eu com o outro, numa alteridade constitutiva. Nessa via, a literatura proporcionaria ao sujeito uma ampliação de sua compreensão do mundo, de si mesmo e do outro. Passamos, então, ao diálogo com a obra eleita para análise.

Raposa é uma fábula contemporânea que discute lealdade, amizade, inveja e traição. Após um incêndio na floresta, Cão, um cachorro cego de um olho, salva Gralha, que teve a asa queimada. Ambos estreitam seus laços afetivos e passam a se complementar mutuamente: Cão torna-se as asas de Gralha, e esta, os olhos de Cão. Mas, "depois das chuvas, quando os brotos aparecem por 
toda parte, uma raposa surge na mata. Raposa com seus olhos ferinos e pelo grosso avermelhado. Ela se esgueira entre as árvores como uma língua de fogo, e Gralha treme de medo" (Wild, 2005, p. I5).

A raposa reúne-se eles. Entretanto, está sempre à espreita, e "seu cheiro parece penetrar na caverna - um cheiro de raiva, inveja e solidáo" (Idem, p. I8). Ardilosa, Raposa tenta gradativamente convencer Gralha a dar um passeio, montada em suas costas, e, de maneira sutil, tenta arruinar a relação de carinho e afeto entre Cão e Gralha.

Nesse livro, a leveza é dada pela estética provocada pela articulação entre o verbal e o visual. A estética provoca o deslocamento da dureza da inveja e da traição, possibilitando o "salto do peso do mundo".

As ilustraçôes transbordam de uma página a outra, e as texturas, cores e traços criam ritmos visuais. Os tons terrosos, que vão do laranja ao marrom, predominam e sugerem o clima de excitação e perigo da narrativa. As palavras se integram às imagens e deslocam-se de um lugar a outro, potencializando a ideia de movimento e aumentando o poder das sequências e, com isso, o leitor é obrigado a mudar a posiçáo do livro (Soares, 20I4, p. I3I).

Como salientado, a obra apresenta intensa interlocução entre o discurso verbal e o visual. As cores, os traços, as linhas, a técnica eleita pelo ilustrador, as letras, sua tipologia e suas diferentes posiçôes e tamanhos nas páginas, tudo isso forma um conjunto integrado que se dá a ler e que também vai propondo outra forma de o leitor se posicionar. Há um jogo de virar o livro e/ou de virar o corpo para ler o texto escrito, que é mais um elemento visual, pois se encontra em diferentes posiçôes da página. Esse jogo, de algu- 
ma forma, pelo movimento do leitor ao buscar o texto, cria outra cadência narrativa.

A narrativa e os diálogos entre os animais da história são concisos, com frases curtas, que deixam espaço para pausa, reflexão e abertura, a fim de que o leitor reflita sobre os acontecimentos de cada página. Os nomes próprios dos personagens são seus nomes comuns: o Cão, a Gralha e a Raposa, como nas fábulas tradicionais. São também comuns as características apresentadas nas próprias açóes dos personagens:

Gralha tenta avisar Cão sobre Raposa:

— Ela não tem amigos, não ama ninguém.

Mas Cão responde:

— Deixa pra lá! Não se preocupe!

Naquela noite, enquanto Cão dormia, Raposa sussurrou para Gralha:

- Eu corro mais depressa do que Cão. Mais depressa do que o vento. Deixe Cão e venha comigo.

Gralha respondeu:

- Nunca deixarei Cáo. Sou o olho que lhe falta e ele é as minhas asas (Wild, 2005, pp. 20-I).

Em cada página, as cenas das ilustraçôes, com os personagens e outros elementos, formam uma composição que também é aberta. Há figuras e fundo, espaços vazios e espaços preenchidos com grafismos. As duas folhas se integram, ora são duas, ora um único palco. A palheta de cores a cada cena varia em tons da mesma nota, com pequenos destaques que se destacam. Todos esses recursos de composição de palavras e imagens apresentam, de forma precisa, a temática abordada. $\mathrm{Na}$ exatidão da forma, os autores imprimem o conteúdo: os sentimentos humanos, que, pela voz dos animais, concentram momentos afetivos e criam um iso- 
lamento da realidade necessário e indispensável à impressão estética. Para Vigotski (200I, p. I20), "a convencionalidade desses heróis garante o isolamento necessário para o efeito artístico", e nós vamos encontrar essa mesma propriedade posteriormente, em todas os personagens da literatura.

Calvino apresenta a rapidez como mais uma proposta da literatura. A rapidez diz respeito ao tempo narrativo, tempo de espera do que se sucederá, tempo do discorrer, da velocidade que impóe ao pensamento, provocada pela concisão de gêneros e estilos. $O$ tempo presente na palavra organizada que não é cronológico, mas apresenta sucessão, simultaneidade e ordem. Para Candido (20II), "quer percebamos claramente ou não, o caráter de coisa organizada da obra literária torna-se um fator que nos deixa mais capazes de ordenar a nossa própria mente e sentimentos, e, em consequência, mais capazes em organizar a visão que temos do mundo" (p. I79). E esse poder organizador se efetiva pelas características que Calvino apresenta como a exatidáo:

I) um projeto de obra bem definido e calculado; 2) a evocação de imagens visuais nítidas, incisivas, memoráveis [...]; 3) uma linguagem que seja a mais precisa possível como léxico e em sua capacidade de traduzir as nuanças do pensamento e da imaginaçáo (Idem, p. 7I).

Tirar as palavras do nada e dispô-las como um todo organizado seria, para Candido (20II, p. I79), o primeiro nível humanizador da literatura. A maneira como o conteúdo é organizado impressiona, faz pensar e amplia as formas de ver e de sentir.

Voltando ao livro Raposa, depois de convencer a Gralha,

Raposa corre pelas colinas, por planícies poeirentas e pelas caatingas, até chegar ao deserto vermelho e quente. Ela para de repente. 
Entre ambos, só há silêncio. Ninguém se move e ninguém diz nada. Então Raposa sacode Gralha de cima de suas costas, como se tirasse uma pulga, e sai andando. Ela se vira, olha para Gralha e diz: "Agora você e Cão saberão o que é solidão". E então ela some. Em meio ao silêncio, Gralha ouve um grito ao longe. Ela não sabe se é um grito de vitória ou de desespero. Gralha junta suas penas, que planam no ar quente. Ela se sente queimando no meio do nada. Seria tão fácil morrer aqui no deserto. Mas, então, Gralha pensa em Cão acordando, descobrindo que ela se foi. E, lentamente, cambaleando, ela começa seu longo caminho de volta (Wild, 2005, pp. 27-34).

Uma fábula que deixa a moral implícita. Faz imaginar um final. O destino da Gralha e suas possibilidades. O final aberto ao pensamento das crianças. A convergência entre ciência, arte e vida traz a unidade de sentido (Bakhtin, 2003). Crianças que não são subestimadas, que são chamadas a viver e a pensar a vida e suas agruras.

Calvino (1990) relaciona a visibilidade à imaginação e à capacidade que a literatura tem de evocar imagens e nos provocar. $\mathrm{O}$ autor distingue dois tipos de processo imaginativo: "O que parte da palavra para chegar à imagem visiva e o que parte da imagem visiva para chegar à expressão verbal" (p. 99). O livro de literatura infantil apresenta esses dois processos simultaneamente, em especial quando deixa espaços indeterminados, inacabados, abertos ao leitor, tanto pela via palavra como pela via da ilustraçáo. As artes têm essa capacidade de nos fazer ver o que, com frequência, não percebemos ou percebemos sob outro ângulo. A arte dá a ver o invisível e o imperceptível.

Se, para Candido (20II), há uma necessidade inerente ao homem de representar a própria vida de forma distinta da realidade cotidiana, para Vigotski (2009), "a imaginação não é um divertimento ocioso da mente, uma atividade suspensa no ar, mas uma 
função vital necessária” (p. 20). A atividade criadora humana é toda e qualquer ação em que se cria algo novo, independentemente de ser mental ou material.

Vigotski afirma que a imaginação é a base de toda e qualquer atividade criadora, sendo comum a todos os homens; ela está por toda parte e em todo lugar, sempre que o sujeito "imagina, combina, modifica e cria algo novo, mesmo que esse novo se pareça com um grãozinho, se comparado às criaçôes dos gênios" (Idem, p. I5). A capacidade imaginativa é também humanizadora, na medida em que nos faz pensar sobre o novo, o possível e até mesmo a utopia. Soares (20I4, p. 135) relata um diálogo que se sucedeu à leitura do livro:

Após a leitura, um menino sussurra:

José Renato: Eu queria que a raposa fosse do bem.

A professora reproduz a enunciaçáo do menino ao grupo:

Professora: Olha, o José Renato disse que queria que a raposa fosse do bem. E vocês, o que acham?

Clarice: Eu acho que ela não era do bem.

Maria Luiza: É, ela era má.

A conversa termina aí, pois a professora de Informática espera pela turma na porta da sala. Apesar disso, duas crianças disputam o livro. Uma delas desiste e acompanha o grupo, a outra senta-se a uma mesa e folheia as páginas do livro. Ela passa as páginas rapidamente e parece procurar por alguma parte da história. Ao se deparar com a imagem da Gralha em cima da Raposa, para, observa... E diz, olhando na minha direção:

Luana: Viu como ela é má?

Depois, fecha o livro rápido e sai da sala para juntar-se ao grupo (Caderno de campo, 21/5/2013). 
Essa fala traz a perplexidade das crianças diante da maldade do personagem, levando Luana a buscar a cena da Gralha nas costas da Raposa para confirmar: "Viu como ela é má?". A maldade ali de olhos reluzentes, amedrontando, mas que se vai ao fechar a página do livro. $\mathrm{O}$ arrebatamento da criança pelo ficcional, mas também sua certeza de que aquela raposa má à espreita pode desaparecer no virar das páginas.

\subsection{Algumas Consideraçóes}

Bakhtin (2003) considera que a arte "me dá a possibilidade de vivenciar, em vez de uma, várias vidas, e assim enriquecer a experiência de minha vida real, comungar de dentro com outra vida em prol desta, em prol de sua significação vital" (p. 74).

Esse enriquecimento também humaniza. Viver outra vida é viver uma rede de possíveis. Sair de si, chegar mais perto do outro. Ser um e muitos. Multiplicidade. Mais uma proposta de Calvino para a literatura. A multiplicidade é parte e exigência do contemporâneo. E, para dispensar os limites, depende dos processos imaginativos de cada um. Esse inacabamento é justamente o que abre as possibilidades do múltiplo: multiplicidade de gêneros, abordagens, estilos, suportes. Se há uma estrutura que sustenta a literatura, há uma arquitetura que recria, reinventa e surpreende.

Ao contrário da natureza, o mundo da cultura é produto da criação humana, e é exatamente essa atividade criativa que possibilita ao homem náo ser um mero reprodutor do passado, mas alguém capaz de alterar o curso do tempo contínuo e escovar a história a contrapelo (Benjamin, I993a). E contamos com cada nova geração para esse projeto. É a consistência, a palestra que náo pode ser finalizada, que fecha as propostas de Calvino para a literatura. Talvez boa parte daquilo a que nos referimos como proposta da literatura, do cinema e de outras artes também possibi- 
lite isso. Entretanto, a literatura destinada a crianças, dentro dos novos paradigmas de infância e literatura, pode ser um espaço de formação e liberdade, de conhecimento de si, do outro e do mundo, de deslocamentos e ampliaçóes, de sensibilidade e humanização. Tudo isso dá mais sentido e consistência à existência. Como diz Bakhtin (2003), "o poeta deve compreender que sua poesia tem culpa pela prosa trivial da vida, e é bom que o homem da vida saiba que sua falta de exigência e a falta de seriedade das suas questóes vitais respondem pela esterilidade da arte" (p. xxxiv).

\section{Referências}

ADORNO, Theodor W. e HORKHEIMER, Max. Dialética do esclarecimento. Rio de Janeiro: Jorge Zahar Editor, 1985.

BAKHTIN, Mikail (Volochinov). Marxismo e filosofia da linguagem. São Paulo: Hucitec, 1992.

- Questôes de literatura e de estética. Sáo Paulo: Unesp,I998.

. Estética da criação verbal. Trad. de Paulo Bezerra. 4 ed. São Paulo: Martins Fontes, 2003.

BARROS. Manuel de. Memórias inventadas: a infância. São Paulo: Planeta, 2003.

BENJAMIN, Walter. Obras escolbidas I: magia e técnica, arte e politica. São Paulo: Brasiliense, 1993a.

. Obras escolhidas II: rua de mão única. São Paulo: Brasiliense, 1993b.

CALVINO, Italo. Seis propostas para o próximo milênio. São Paulo: Companhia das Letras, 1990.

CANDIDO, Antônio. "O direito à literatura". Vários escritos. Rio de Janeiro: Ouro sobre Azul, 2oIr.

CASTRO, Lúcia Rabello de. O futuro da infância e outros escritos. Rio de Janeiro: 7 Letras, 2013 .

COMPAGNON, Antoine. O demônio da teoria. 2 ed. Belo Horizonte: Ed. UFMG, 20IO. 
Literatura para quê? Belo Horizonte: Ed. UFMG, 2009.

CORSARO, Willian. Sociologia da infância. Porto Alegre: Artmed, 201.

EAGLETON, Terry. Teoria da literatura: uma introdução. São Paulo: Martins Fontes, 2006.

MEIRELES, Cecília. Problemas de literatura infantil. Rio de Janeiro: Nova Fronteira, 1984.

POSTAMAN, Neil. O desaparecimento da infância. Rio de Janeiro: Graphia, I999.

SARMENTO, Manuel. "A reinvenção do ofício de criança e de aluno". Atos de pesquisa em educação, Furb, v 6, n. 3, pp. 58I-602, $201 \mathrm{I}$.

SOARES, Carolina Monteiro. Viagens literárias por palavras e imagens: o livro ilustrado e a leitura na escola: uma experiência na educaçáo infantil do Colégio Pedro II (dissertação). UFRJ, 2014.

SOUZA, Solange Jobim e. "Re-significando a psicologia do desenvolvimento: uma contribuição crítica à pesquisa da infância”. In KRAMER e LEITE (orgs.). Fios e desafios da pesquisa. Campinas: Papirus, I996, pp. 39-55.

VIGOTSKI, Lev Semenovitch. Psicologia da arte. Trad. de Paulo Bezerra. São Paulo: Martins Fontes, 200I. . Imaginação e criação na infância. Trad. de Zoia Prestes. São Paulo: Ática, 2009. 


\title{
9 \\ Leituras literárias em grupo: experiências, desafios e objetivos
}

Neide Luzia de Rezende

Gabriela Rodella de Oliveira

\author{
A Richard Marcello \\ (in memoriam)
}

\begin{abstract}
"O que sucede com o leitor quando sua leitura dá vida aos textos ficcionais?”
\end{abstract}

WOLFGANG ISER

Neste artigo, procuramos estabelecer uma ponte com a entrevista realizada com Annie Rouxel para a revista Teias (Rezende e Oliveira, 2015). A entrevista, embora assentada no contexto francês, dispóe de elementos que, comuns tanto à situação brasileira como à educação literária, permitem trazer à tona questóes fundamentais para repensar nosso ensino de literatura. Assim, ainda que existam grandes diferenças dos pontos de vista social e cultural, uma problemática metodológica em relação a esse ensino se apresenta quando a entrevistada fala do contexto histórico do início de suas pesquisas, nos anos I980:

$\mathrm{O}$ acesso ao ensino médio se abre às crianças oriundas de meios modestos, ao passo que antes esse nível de ensino era frequentado sobretudo por jovens dos meios privilegiados, "os herdeiros", como os denominou Bourdieu. Esse fenômeno de massificação, de democratização, se ampliou progressivamente e transformou profundamente 
o público escolar. A distância cultural que separava esses "novos colegiais" dos textos estudados na escola levava a repensar o ensino da literatura (Rezende e Oliveira, 20I5, p. 28I).

Esse fenômeno de democratização do ensino médio levou os educadores franceses a repensar alguns aspectos da didática da literatura que, desde então, têm sido objeto naquele país tanto de intervenção oficial como de confronto no interior das instituiçôes educativas e das publicações voltadas à educação. ${ }^{\mathrm{I}}$

Contemporaneamente, uma vertente importante que Annie Rouxel $^{2}$ integra detém-se no denominado "sujeito-leitor", ${ }^{3}$ o qual supõe "formar um leitor implicado, que é o que considero o valor da leitura subjetiva [...]. O que interessa, no momento atual, é a singularidade da recepção e o processo de leitura, e não mais a conformidade a uma norma ou a uma resposta esperada" (Idem, p. 282).

Investigar a singularidade da recepção em situaçóes de educação formal no Brasil, sob os pressupostos ligados à recepção, a partir dos textos da Estética da Recepção de Hans Robert Jauss e também da corrente americana do Reader Response Criticism (em especial, Wolfgang Iser e Stanley Fish), tem delineado um caminho que percorremos já há alguns anos. Por isso, consideramos uma contribuição valiosa nessa linha os aportes teóricos e práticos trazidos pelo grupo do Sujeito-Leitor, voltado essencialmente

I Entre as publicaçôes, destacamos o artigo de Jean Verrier, publicado na revista Educação e pesquisa (2007), sobre a crise instalada na educação a propósito do ensino de literatura, quando a abertura para leituras do universo juvenil na escola instaurou enorme discussão no início dos anos 2000, polêmica traduzida pela mídia como "uma escolha binária: ensino light ou cursus clássico".

2 Representantes importantes desse grupo encontram-se no livro traduzido por nosso Grupo de Pesquisa Linguagens na Educação, em ROUXEL, Annie et al. (orgs.), 2013.

3 "O sujeito-leitor não é reduzível ao indivíduo, mas à parte do indivíduo que se manifesta quando ele se engaja na leitura: é um sujeito móvel, cambiante, cuja identidade não é estável, ao contrário, 'nâo cessa de se fazer e desfazer' ao longo das leituras" (Rezende e Oliveira, 20I5). 


\section{à didática da literatura, à leitura literária e à formação do leitor} na escola.

Neste artigo, colhemos três situaçóes de leitura em grupo para discutir as possibilidades de se construir um percurso que leve à emergência e à manifestação do sujeito-leitor, indo do engajamento afetivo - que todo leitor vivencia quando lê um texto literário - às significaçóes mediante o ato interpretativo ${ }^{4}$ (Iser, 1996). Esperamos, ao final, apresentar possibilidades coletivas de trabalho com a literatura, com vistas à formação de um leitor em situação de aprendizagem.

Os exemplos a seguir são situaçóes de leitura realizadas com grupos que congregam indivíduos com aspectos em comum (idade, grupo social, profissão, interesses etc.), o que poderia configurar aquilo que Stanley Fish chama de "comunidades interpretativas", um conjunto de pessoas que partilham estratégias de leitura, apreendidas em suas interaçóes sociais. ${ }^{5}$ Acreditamos que as refe-

4 Para Iser, "o texto de ficção existe por causa do efeito que ele provoca em nós", assim em lugar de "decifrar o sentido, [a interpretação], deve explicitar os potenciais de significação do texto" (Iser, 1996, v. I).

5 'No ensaio 'Interpreting the Variorum [Interpretando o Variorum]', Fish afirma que um texto não tem significado fora de um conjunto de conjecturas culturais, as quais ditam o que significam as palavras e como devem ser interpretadas. Tais conjecturas podem ou não incluir as intençôes do autor, embora nunca se limitem a elas. O teórico norte-americano defende que o nosso modo de ler e interpretar está diretamente ligado à comunidade à qual pertencemos, pois ela é responsável por nos dar as formas específicas, as estratégias de leitura, com as quais lemos. Depreende-se de Fish que uma estratégia de leitura é um mapa, o qual indica um certo conjunto de direçôes variáveis, mas que sempre conduzirá a um ponto de chegada, pois a estratégia também inclui os significados do texto. No entanto, não se deve entender tal lugar como interpretação única, e sim como um número possível de ocorrências no interior de um perímetro delimitado pelo contexto cultural no qual os intérpretes se inserem." Esse trecho explicativo foi extraído do relatório de qualificação de Mestrado de Richard Marcello, falecido em Is de dezembro de 2009, seis meses após a sua qualificação. O objetivo da dissertação era refletir sobre a leitura literária na escola, "concebendo as interaçôes entre leitor e texto a partir de certas concepçốes do chamado Reader Response Criticism norte-americano, sobretudo as noções de indeterminação de Wolfgang Iser e a de comunidades interpretativas de Stanley Fish, indagando-se sobre as semelhanças e/ou diferenças no preenchimento das lacunas textuais fundamentais à interação nas leituras de prazer e nas leituras de co- 
rências em comum possibilitam ao mediador prever e traçar, até certo ponto, um caminho que estimule a discussão e engaje os participantes, de modo a construir um saber sobre a literatura, um saber sobre si e sobre o mundo, no contato com esse outro que é o texto literário, o que Iser denomina "efeito estético".

\section{I Na licenciatura}

Os estudantes de licenciatura no Brasil são muito diferentes. Nas salas de aula da Faculdade de Educação da USP, por exemplo, na disciplina de Metodologia de Língua Portuguesa, do curso de Licenciatura, ${ }^{6}$ encontram-se leitores com uma trajetória literária já bastante consolidada em termos de formação, de recursos teóricos analíticos e de definiçáo de gostos, sujeitos capazes de refletir sobre o atual estado do ensino de literatura nas escolas, levando em conta as açôes dos alunos e dos professores, que observam nas salas de aula em que desenvolvem seus estágios.

Mesmo assim, existem depoimentos que apontam para uma sensação de falta, memórias que sugerem uma suposta dívida em relação à cultura letrada ou erudita, também observando em si a precariedade do repertório literário, em se tratando de um estudante de Letras oriundo da FFLCH-USP. Contudo, conhecem um bom número de textos canônicos da história literária brasileira e conhecem bem os textos teóricos de especialistas da área sobre eles.

Já em uma universidade instalada na periferia da Bahia, fundada como inclusiva e voltada a uma comunidade cujas origens são

\footnotetext{
nhecimento". Funcionalizá-lo aqui também permite prestar homenagem a um pesquisador que, professor de inglês, era um ávido leitor de Fish e introduziu este autor no Grupo de Pesquisa Linguagens na Educação.

6 Neide Luzia de Rezende é professora da disciplina há vinte anos e Gabriela Rodella de Oliveira ministrou-a durante o ano de 2015 .
} 
bem menos favorecidas do ponto de vista socioeconômico, encontram-se estudantes da área de Linguagens que igualmente se ressentem da falta de leitura, mas que náo sabem por onde começar: o que ler, como ler, quando ler, por que exatamente ler; desconhecem o que seria um cânone escolar, o que poderia ser o ensino de literatura na escola ou mesmo o que seria o jogo de forças dentro do campo da literatura ${ }^{7}$ no Brasil. Esse desconhecimento de uma cultura escolar convencionada dificulta ou mesmo impede a problematização do ensino de literatura nas escolas, o que leva esses jovens a identificar o desinteresse dos alunos observados em seus estágios como o principal fator do fracasso do ensino dessa disciplina.

Nessa universidade (Universidade Federal do Sul da Bahia), como atividade da primeira aula do componente curricular Ensino de Literatura e Leitura Literária a estudantes com dois ou quase três anos de experiência em curso superior na Licenciatura Interdisciplinar em Linguagens, procedeu-se uma conversa acerca de seus hábitos de leitura. Quando interpelados sobre quais livros se lembravam de ter lido na escola, uma estudante citou um de que havia gostado muito, A Ladeira da Saudade, de Ganymédes José (publicado em 1983), romance sobre o amor de uma adolescente de Ouro Preto no século XX e sobre preconceito racial. Outra estudante comentou que se lembrava de ter tido uma experiência intensa de leitura com a saga Crepúsculo fora da escola. Outro autor citado foi Augusto Cury, conhecido escritor de autoajuda muito presente no campo da educação, cuja obra passou a fazer parte inclusive do currículo do

\footnotetext{
7 Acionamos aqui o conceito de campo como o define Pierre Bourdieu (1990): espaços relacionais dentro dos quais as pessoas (os agentes) têm interesses comuns, competências mais ou menos semelhantes, estruturas mentais mais ou menos semelhantes, bem como ilusóes comuns (estados de paixão). Os sujeitos que participam de um campo compartilham o interesse pelos mesmos objetos e disputam as mesmas coisas, o que faz do campo um espaço de batalha, luta de forças, jogo.
} 
Ensino Fundamental II de uma escola particular bem conceituada na regiáo. Quando questionados de quais autores do cânone escolar se lembravam, nunca haviam nem ouvido falar de alguns, como João Guimarães Rosa, Carlos Drummond de Andrade, João Cabral de Melo Neto e Manuel Bandeira. Lembravam-se de Machado de Assis, de José de Alencar (citando, inclusive, os nomes de alguns romances), de Mário de Andrade (a cuja adaptaçáo fílmica de Macunaima haviam acabado de assistir na aula da professora com a qual estavam estagiando). Clarice Lispector e Oswald de Andrade, eles conheceram na universidade: haviam lido um conto da primeira em um dos componentes cursados e, em outra ocasiāo, o Manifesto Antropófago, do segundo.

Em trabalhos finais do componente curricular de Estágio Supervisionado, duas estudantes relataram a frustração de uma professora de português do ensino médio de uma escola pública por não conseguir a adesão de seus alunos à apresentação de trabalhos sobre Fernando Pessoa, mesmo depois de haver cedido uma aula para a preparação de seminários sobre os heterônimos do poeta. As estudantes consideraram que o desinteresse e, talvez, certa vergonha (que elas mesmas costumam sentir em atividades propostas na universidade) fossem a causa dessa desistência ou da resistência à apresentação dos seminários. A sala especial agendada e preparada para a atividade ficara vazia. Quando inquiridas sobre o que fora realizado em sala de aula antes da proposta dessa atividade de pesquisa e do planejamento do seminário, elas náo tinham o que dizer, pois haviam acompanhado a professora apenas nas terças-feiras à noite; lembraram-se de que esta copiara um poema de Pessoa no quadro e de que solicitara aos estudantes que resolvessem as questôes de um livro didático sobre a obra. À pergunta sobre se a atividade havia interessado aos alunos, responderam 
que muitos haviam ficado em seus celulares, conversando baixinho pela sala, do que se deduziu que náo houve engajamento. ${ }^{8}$

Partiu-se, então, para uma conversa sobre a saga Crepúsculo. Apesar de ser um romance sobre lobisomens e vampiros, a estudante explicou que tudo parecia ser verdadeiro, que tudo se encaixava na narrativa e náo havia nada fora do lugar, nada que destoasse, que a narrativa a prendia e ela náo conseguia parar de ler. A partir desse comentário e daquilo que trouxeram como características que as levavam a acreditar na verdade das narrativas lidas, discutiram-se a concepçáo de enredo e a importância do conceito de verossimilhança para a literatura, as relaçóes entre ficção e realidade, a fantasia, as personagens híbridas - meio homens, meio monstros - o grotesco, o horror, o terror.

A conversa derivou para uma reflexáo sobre $A$ metamorfose, de Kafka, romance que as estudantes haviam começado a ler a pedido de outro professor, mas que ainda não haviam conseguido finalizar. Uma inquietação sobre como seria possível um homem acordar e ter-se transformado em um inseto foi trazida por elas. Depois de discutir em sala a importância da coerência interna do texto, mediante o conceito de verossimilhança, indagamos o que poderia significar essa transformação, premissa básica da narrativa kafkiana. Divagando, a situação de se ter um inseto enorme fechado dentro de um quarto foi comparada à de um filho que, por

\footnotetext{
8 A imagem construída da leitura literária na escola - de obrigação, tédio, experiência sem prazer - tem tido, nos últimos anos, quando os estudos sobre o ensino de literatura se tornaram mais frequentes, múltiplas tentativas de análise e respostas. Por isso evitamos aqui buscar explicaçôes para essa imagem, uma vez que seria preciso analisar o contexto e também as nossas próprias expectativas sobre o que e como ensinar literatura. Muito já se disse sobre a inocuidade de certos procedimentos: prender-se à rotina com o livro didático e suas atividades; pedir para que os estudantes façam seminários em que apresentam o que pesquisaram na Internet sobre um autor ou um poema; levar os estudantes à adaptação cinematográfica de uma obra de ficção, na intenção de substituir uma coisa por outra. Destacamos esses três exemplos porque, em geral, são os relatados com mais frequência pelos estagiários.
} 
algum motivo, se torna um estorvo para a família. Levantaram também a proximidade das palavras metamorfose e metáfora, indagando se essa aproximaçáo seria pertinente. Nesse momento, uma das estudantes comentou sobre seu desejo de voltar a ler o romance e de terminá-lo.

\subsection{No cursinho pré-vestibular}

Um segundo exemplo foi extraído de um trabalho realizado por nós e comentado em artigo publicado na revista Diadorim, da Universidade Federal do Rio de Janeiro (Rezende e Oliveira, 20I6). Trata-se de um debate interpretativo ocorrido em sala de aula de um cursinho pré-vestibular oferecido a estudantes da rede pública paulista pela reitoria da USP. 9

A proposta consistia em abordar, em aulas regidas por licenciandos da Faculdade de Educação da USP, os livros de literatura da lista da Fuvest de 20I4. Em um debate iniciado em sala sobre Vidas secas, de Graciliano Ramos, com a leitura do primeiro capítulo em sala de aula, os alunos evidenciaram a dificuldade e a lentidão como efeitos na recepção da obra. Tais sensaçôes, aliadas a uma dificuldade na leitura em voz alta do capítulo feita em sala, só puderam ser trabalhadas com o apoio de uma discussão acerca dos livros que os estudantes haviam lido e dos quais gostaram.

Entre as características listadas do que podemos denominar leituras anárquicas (Petrucci, 1999), realizadas fora da escola, foram citados heróis ou heroínas com os quais os leitores podiam iden-

9 Trata-se do Programa Preparatório para o Vestibular da USP (PPVUSP), criado em julho de 2013, com o objetivo de aumentar as possibilidades de bons alunos da rede pública ingressarem na universidade. Foi um projeto-piloto de curso pré-vestibular ministrado por alunos de licenciatura da USP, sob a supervisão de docentes e pós-graduandos. Ficamos responsáveis pela supervisão geral da área de Língua Portuguesa (Neide Luzia de Rezende), bem como por sua coordenação pedagógica (Gabriela Rodella de Oliveira), tendo sido as aulas ministradas em diferentes unidades da USP. 
tificar-se, dinamismo de ação, capítulos curtos com ganchos narrativos, diálogos constantes e formalmente marcados - de resto, preferências comuns de jovens leitores, como aparece na pesquisa longitudinal realizada com alunos do ensino médio na França, divulgada no livro da equipe do sociólogo Christian Baudelot (Baudelot et al., 1999), em que os autores concluem que, embora resistam à leitura indicada pela escola, pourtant ils lisent! (... no entanto, eles leem!).

A discussão propiciada por esse levantamento dentro da sala do "cursinho" levou os jovens aspirantes à USP a pensar no que lhes dava prazer no ato de ler ficção - chegando ao questionamento, por comparação, de qual poderia ser a função de uma literatura diferente desta à qual estavam acostumados (e que alguns autores como José Paulo Paes, Umberto Eco, Hans R. Jauss denominam experimental, erudita, em contraposição à literatura de entretenimento, gastronômica, culinária, de massa..., mas que também conhecemos, respectivamente, por complexa, adulta, universal ou, simplesmente, literatura...) - ao que responderam: a reflexão.

Assim, por meio do debate sobre os textos que costumam ler e aquele proposto para a leitura em sala de aula, os estudantes se aproximaram da distinção proposta por Umberto Eco (1989) entre obras que visam ao prazer do "leitor-vítima", que busca apenas se entreter com o enredo e é presa fácil das armadilhas do texto, e aquelas que visam ao prazer do "leitor crítico", que se interessa também pelo "como" a história é narrada. $\mathrm{Ou}$, de acordo com as formulaçôes de Iser, obras que se diferenciam pela presença ou ausência de "lugares vazios", quando, "omitindo suas referências, forçam o leitor a se desfazer de parte de suas expectativas habituais e o induzem "a encontrar a relação não formulada" (Iser, I999, v. 2).

A partir de então, a leitura de Vidas secas pôde ser problematizada e ganhou sentido, construído, de modo compartilhado, a 
partir da análise de questôes formais, para as quais foram atribuídos significados, o que aqui estamos denominando debate interpretativo. Transpomos, a seguir, trecho do relato que escrevemos para a revista Diadorim, de modo a esclarecer o tipo de trabalho capaz de estabelecer pontes entre a literatura dos jovens e a literatura mais complexa e estudada na escola.

No debate, foi possível constatar que a inexistência de diálogos explícitos era, na verdade, um obstáculo para a leitura dos alunos. $\mathrm{O}$ discurso indireto livre, marca do narrador de Graciliano, não havia sido compreendido por eles, o que causava um ruído na recepção e a sensação de que a leitura não avançava. Questionados sobre as razóes que teriam levado o autor a utilizar esse recurso, uma das alunas aventou a hipótese de que as personagens do romance não conseguiam falar. A partir daí, os posicionamentos sobre as razóes dessa impossibilidade de fala, o uso de um narrador que "fala pelas personagens", a dificuldade de leitura que se cria em função desse modo de apresentação e as diferenças entre as questóes formais dos livros que eles estavam acostumados a ler e Vidas secas fizeram avançar com consistência a discussão. Paulatinamente, mais alunos procuravam se posicionar em relação à leitura proposta e hipóteses interpretativas foram surgindo.

Perceber que os colegas também haviam passado por dificuldades na leitura, a oportunidade de discuti-las em sala e a abertura para a construção de uma interpretação conjunta ofereceram aos alunos um espaço de liberdade e autonomia para se manifestarem tanto sobre uma interpretação mais madura, requerida pelo trabalho de ensino, quanto para a apreensão mais subjetiva da obra, fundamental para construir o saber mais especializado. A questão social presente na obra ganhou força e o fato de o texto ser "lento" apareceu como qualidade: "É que ele fica mais perto da realidade" (Rezende e Oliveira, 2016, pp. 167-8). 
O que pode e o que náo pode ser dito dentro de uma sala de aula? O que pode ou não pode ser assumido em termos de práticas de leitura nas situaçóes formais de educação?

\subsection{No grupo de vivências}

Dessa vez, o outro exemplo de prática de leitura literária foi posto em prática em uma instância de formaçáo diferente, gerada da prática de letramento Pensar Alto em Grupo, de professores-pesquisadores do Grupo de Estudos da Indeterminação e da Metáfora (Geim), vinculado à PUC-SP.

Para responder aos objetivos de sua tese, na área da Linguística Aplicada, cujo tema central era investigar as possibilidades das múltiplas leituras do texto literário, Ariane Mieco Sugayama (20I7) constituiu um grupo de vivências de leitura literária de quatro integrantes: uma bibliotecária de um dos Centros Educacionais Unificados (CEUs-SP); uma professora de um curso de especialização sobre literatura infantil e juvenil em uma instituição educativa e cultural privada; uma produtora cultural na área da dramaturgia infantil em uma unidade do Serviço Social do Comércio (Sesc-SP); e uma doutoranda na área da tradução, cujo objetivo era investigar a recepção por parte de crianças inglesas dos poemas infantis de Cecília Meireles, traduzidos do português para o inglês. A finalidade pensada para o grupo era: (I) investigar as múltiplas leituras da linguagem figurada e das lacunas/silêncios do conto $A$ moça tecelâ, de Marina Colasanti, e (2) analisar os processos sociocognitivos envolvidos nessas interpretaçóes. ${ }^{\text {Io }}$ Segue a descrição da proposta feita às leitoras por Ariane:

Io Vamos nos deter aqui às falas das participantes resultantes das projeçôes permitidas pela leitura do conto, deixando de lado os processos sociocognitivos. 
Dados os informes iniciais, comecei a coordenação da vivência do Pensar Alto em Grupo, entregando a cada uma das participantes uma cópia colorida e digitalizada do livro $A$ moça tecelâ, de Marina Colasanti. Com o texto em mãos, disse às leitoras que teriam um tempo para realizar uma leitura solitária e introspectiva. Comuniquei também que não precisavam se preocupar, caso surgissem problemas no momento da leitura individual, pois poderiam ser discutidos e solucionados no grupo. Além disso, orientei as participantes a fazer anotaçóes sobre aspectos do texto que mais lhes chamaram a atenção, caso desejassem. Por esse motivo, nesse momento de leitura individual, entreguei-lhes sulfites em branco e canetas para escreverem o que quisessem. Destarte, passado esse primeiro momento do Pensar Alto em Grupo, após todas terem lido o conto de forma individual e introspectiva, avisei às leitoras que iniciaríamos, portanto, o segundo momento dessa prática de letramento, no qual seriam compartilhadas, no grupo, suas observaçôes individuais, assim como refletiríamos sobre o texto colaborativamente. Em relação ao segundo encontro, repeti novamente essas orientaçóes sobre o funcionamento da prática Pensar Alto em Grupo e logo após a leitura individual e introspectiva, disse às participantes que elas poderiam expressar novas leituras, inquietaçóes pessoais e reflexóes, caso tenham surgido após a primeira vivência (Sugayama, 2017, p. 159).

Para a análise acerca das leituras realizadas, Sugayama selecionou excertos das interaçóes com as participantes das duas ediçóes das vivências, segundo ela a partir de uma "metodologia qualitativa de orientação interpretativista", "I porém o que nos levou a trazer tal experiência para a discussáo neste artigo foi o percurso feito

II De acordo com Moita Lopes (1994, pp. 329-38). 
pelas participantes. Assim, ao pensar alto em grupo, com a mediação da professora Ariane, inicialmente elas trouxeram para a conversa elementos do texto associados à vida pessoal ou às suas ideologias. Em seguida, pelo efeito da mediação e da intersubjetividade, reconduziram o trajeto até alcançar uma interpretação mais consensual, mediante o entendimento dos recursos metafóricos e da construção alegórica do conto. ${ }^{12}$

A narrativa de $A$ moça tecelâ se constrói, a exemplo do que diz Iser (1996), de vazios e silêncios, "necessitando, portanto, que as leitoras se posicionassem de forma ativa e responsiva para construir leituras" (Idem, ibidem). Segundo Sugayama, o trabalho proporcionou observar "a convivência mútua de visões diferentes, revelando uma polifonia de vozes mobilizadas por subjetividades que são únicas, mas não autônomas uma em relação à outra" (Idem, p. 218).

Para responder à dimensão e aos objetivos deste artigo, não é possível transcrever mais do que algumas falas, o que realmente lamentamos, uma vez que a transcrição, no âmbito das vivências, feita na tese mostra projeçóes riquíssimas realizadas pelas participantes.

Eu tô vivendo agora um processo de separação... e aí vêm todas essas questôes

mesmo né... de...destecer (Camila). ${ }^{13}$

\footnotetext{
I2 Para o desenvolvimento das análises, Sugayama afirma ter procurado "estabelecer um diálogo contínuo entre os dados que emergiram das duas vivências de Pensar Alto em Grupo e as diversas abordagens teóricas e estudos — a Teoria da Mesclagem Conceptual (Fauconnier e Turner), a Teoria da Parábola (Turner); a Teoria da Metáfora Conceptual (Lakoff e Johnson; Lakoff e Turner) e os estudos de Zanotto e Moura e Zanotto.

I3 "Após detalhar melhor o que queria dizer, Camila prosseguiu na interpretaçáo do conto, refletindo sobre a metáfora do tecer/destecer o marido" (Sugayama, 2017, p. I73)
} 
[...] foi a leitura da "volta à essência" a que calou mais fundo em mim, que mais fez sentido pra mim. De certa forma, ao aceitá-la, voltei à minha essência, pois acredito, a despeito das forças contrárias ao "essencialismo", que todos temos, sim, uma "essência", e que, mesmo perdida, pode ser reencontrada, um dia. Ou talvez não seja bem uma essência, mas uma aspiração: quase como uma "missão", ou um "destino" a ser cumprido. Acreditar nisso é algo que me faz feliz (Diário de Talita, negrito da autora). ${ }^{\mathrm{T}}$

Eu acho que é uma narrativa que fala muito do poder do feminino também, mas ao mesmo tempo das fragilidades (Carla, negrito da autora).

A discussão, a partir da manifestação de Carla, abriu-se intensamente para as questóes do feminino e de seu empoderamento contemporâneo.

Logo em seguida, o grupo começou a discutir sobre o fato de a protagonista estar presa a esse tipo de casamento opressor, a partir da reflexão de elementos no conto fonte, como "torre" e a figura opressora do marido, estabelecendo um diálogo intertextual com o conto de fadas Barba Azul (Sugayama, 2017, p. 167).

A composição do grupo, de mulheres letradas com profissóes ligadas também às letras e à educação, permitia o estabelecimento de relações intertextuais com obras contemporâneas e mitos (por

\footnotetext{
I4 Após as vivências, algumas participantes fizeram um "diário de leitura", que Sugayama utilizou para análise, assim como as conversas gravadas. Sobre a proposta metodológica dos diários de leitura, é possível entendê-la como um procedimento formativo de registro de reflexôes, questóes e problemas advindos da leitura de um texto, como propóe Anna Rachel Machado (1998), ou um espaço para a coleta de excertos que compóem uma identidade literária do sujeito-leitor, complementados ou não por comentários subjetivos e espontâneos não excludentes de saberes discutidos em situaçôes formais de ensino, como propóe Annie Rouxel (2013).
} 
exemplo, O filho de mil homens, de Valter Hugo Mãe, e o mito de Perséfone e Hades).

As situaçóes foram diferentes com um público igualmente diverso: I. alunos do ensino superior no curso de licenciatura, com pouco conhecimento de textos clássicos; 2. alunos do ensino médio em situação de cursinho pré-vestibular, com bastante informação sobre a lista canônica do vestibular da USP, mas que praticamente não haviam lido nada dessa lista; 3 . profissionais diversos em situação de pesquisa, com práticas e repertórios desconhecidos, mas leitores críticos.

O primeiro (I) e o segundo (2) exemplos trazem objetivos, em tese, mais ou menos semelhantes, não obstante constituam diferentes etapas de aprendizagem. Os alunos da universidade, num estágio superior de escolaridade, têm, aparentemente, dificuldades que se aproximam daquelas dos alunos aspirantes à universidade. Entretanto, existem particularidades de ambos os grupos que, se identificadas e bem avaliadas, são capazes de direcionar o trabalho do professor. Ou seja, essas particularidades advêm dos objetivos — não só aqueles a que se propóe o educador, mas também aqueles obrigados pela situação de ensino.

Esse foi o caso do componente curricular do curso de licenciatura da UFSB, cujo objetivo geral, descrito na ementa, é o de "promover a reflexão crítica sobre o ensino de literatura (baseado na história da literatura) atualmente em vigor nas escolas e fomentar novas abordagens da literatura por meio da leitura literária”. Para alcançar tal meta, pressupôs-se o conhecimento de certo cânone literário escolar em língua portuguesa, de modo a problematizar sua permanência e repensar o método. Diante da ausência de um saber prévio consolidado desse cânone, deu-se ênfase à leitura e à análise, em sala de aula, de obras literárias do universo da 
dita "cultura juvenil", ${ }^{15}$ por meio de debates interpretativos. Nesse caso, o docente torna-se um mediador, pois não impóe seu saber de especialista e, assim, não silencia os estudantes leitores, mas constrói, junto com eles, problematizaçóes que funcionam como uma chave para novas leituras de textos mais complexos, como base para a reflexão sobre seu futuro papel na formação de alunos do ensino básico. Como diz Max Butlen (apud Bueno e Rezende, 20I5), embora se suponha classicamente que o professor ajude o aluno a descobrir o texto do autor, "não é incomum que seja um obstáculo para a aparição do texto do leitor, até finalmente impor uma leitura magistral" (p. 560).

O mais importante é conseguir fazer com que esses indivíduos possam construir esse saber no diálogo coletivo. Na verdade, a manifestação de cada um, as lembranças e os fragmentos de leitura e de impressóes de leitura que afloraram na sala foram acontecimentos que antecederam o debate interpretativo, uma vez que, de início, o que se vê no relato da conversa é ainda a emergência de percepçóes muito individualizadas, como se, naquele momento, diante dos questionamentos do professor, os jovens tomassem consciência de suas leituras; segundo Iser (I996, v. I), "a obra é a constituição do texto na consciência do leitor”.

Assim, as memórias de leitura, como manifestação a posteriori do sujeito-leitor - quando este já se encontra distante no tempo da interação imediata com a obra e de suas implicaçôes afetivas -, propiciam que o conteúdo dessas lembranças seja percebido a partir da história do indivíduo. Sensaçóes e questóes da vida presente agem para reelaborar essa história e adaptá-la a um discurso possível para aquele momento escolar - quando o estudante é

I5 Usamos aqui a expressão entre aspas por considerar que, embora recorrente nos documentos oficiais recentes, é necessário tecer mais discussão a esse respeito, uma vez que pode cobrir um amplo leque de manifestaçôes culturais, sem que, de fato, se saiba como seria sua presença no universo escolar. 
instado, em face de seus colegas, a se posicionar -, construindo uma posição de leitor que possivelmente desconhecia e que não se manterá igual, pois, como diz Annie Rouxel, trata-se de "um sujeito móvel, cambiante, cuja identidade não é estável, ao contrário, 'não cessa de se fazer e desfazer' ao longo das leituras" (Rezende e Oliveira, 2015, p. 286).

E, no trabalho que respeita e acolhe essa instabilidade das identidades de leitores, lembramos aqui uma questão levantada por Max Butlen (Bueno e Rezende, 2015), citando Pierre Bayard: "Na medida em que o 'texto se constitui de uma parte importante de reaçóes individuais de todos aqueles que o encontram e o animam com sua participação', como organizar e gerir em sala de aula essa polifonia interpretativa dos leitores?” (p. 560).

Como possível resposta a essa questão, defendemos que o ato interpretativo, ou, no coletivo da sala de aula, o debate interpretativo, torna possível entender como procedimentos estéticos conduzem à significaçáo, como o aspecto verbal dirige a interpretação. Expostas as impressôes de leitura, o professor, apreendendo, aproveitando as dúvidas e o entusiasmo da aluna que leu Crepúsculo, passa a inquirir sobre os aspectos que considerou necessários para os saberes que pretendia introduzir sobre literatura, trazendo questôes relativas à verossimilhança, percurso fundamental para a articulaçáo da experiência afetiva e verbal, uma vez que ensina o fabuloso poder do simbólico: "Em lugar de ser o contrário da realidade, a ficção nos comunica algo a respeito da realidade" (Iser, I999, v. 2).

No grupo de estudantes de licenciatura do sul da Bahia, a maioria trazia em comum a ausência de um repertório de leituras "legitimadas" e de uma postura crítica e distanciada, de um exercício racional que levasse ao ato interpretativo. Entretanto, a mobilização das leituras que faziam por conta própria, que utilizavam para si (Rouxel, 2013), a fim de responder às necessida- 
des afetivas de seu universo pessoal, e que eram também leituras compartilhadas com amigos e redes sociais, funcionou como ponte necessária para estabelecer relaçóes intersubjetivas, negociar e compartilhar significados.

A discussão sobre suas práticas pessoais de leitura, seguida da leitura de um texto literário e do debate interpretativo sobre ele, bem como de atividades que se deram em grupo e na sala de aula, garantiu a construção de um saber literário compartilhado e legítimo. Dessa forma, os estudantes percebem que podem ocupar o espaço formal da educação a partir de suas indagaçóes e questóes pessoais.

Do mesmo modo, os vestibulandos do PPVUSP lançaram mão de seu universo de conhecimento prévio para alcançar significados mais "sociais" exigidos na compreensão e na interpretação do livro Vidas secas, o que realizaram à luz de um repertório de leituras menos complexas, com textos marcados por um grau mínimo de indeterminaçáo e pelo preenchimento das lacunas entre texto e leitor. Tais obras, dirigidas a um público amplo e global, estabelecem protocolos mais próximos de uma cultura comum, que, hoje, cada vez mais tem-se tornado homogênea, em face das aproximaçôes promovidas pela comunicação, sobretudo a digital.

A expectativa que se tinha da disciplina de Literatura para esse cursinho vestibular (com a duraçáo de três meses) deveria ser a de aproximar os jovens das obras listadas no manual da Fuvest, a exemplo do que fazem instituiçôes que comumente preparam para o vestibular. Entretanto, por ser ofertado dentro de uma universidade (que tem como um de seus eixos a pesquisa), optou-se por uma abordagem livre, desenvolvida no âmbito das pesquisas sobre o ensino de literatura, as quais se opóem ao método de ensino de história literária traduzida na linha do tempo e baseada em causas e consequências da sequência de obras de um cânone escolarmente instituído. 
Nesse contexto, optou-se por selecionar poucas obras para discussão em sala (Vidas secas, Memórias de um sargento de milícias, dois poemas de Sentimento do mundo, Viagens na minha terra) e aprofundar sua leitura, para entender como nelas aparecia a História (Barthes, 2008), e como eram formalmente construídas, sobretudo em relaçáo a categorias de análise que fazem parte dos programas de ensino médio, mas sobre as quais, de fato, os estudantes tinham pouco conhecimento. Como exemplo, temos o estudo e a compreensão efetiva do discurso indireto livre, fundamental para a narrativa moderna e para a construçáo do romance de Graciliano Ramos.

Diferentes foram as finalidades da pesquisa, a qual utilizou a prática de letramento Pensar Alto em Grupo - tanto utilizada pelos professores-pesquisadores do GEIM em seus trabalhos acadêmicos como apresentada aos docentes que desejam transformar suas açôes didáticas de leitura, a partir da realizaçáo do curso de especializaçáa "Construindo uma prática de letramento para formação do leitor", da Cogeae, na PUC-SP.

A intenção da autora em sua pesquisa era vasculhar em profundidade as leituras possíveis de um texto bastante lacunar, cuja alegoria abria para interpretaçóes múltiplas, mas que remetiam, em última instância, a questôes do feminino. Então, o grupo de profissionais da área de humanas, com curso superior, constituía uma comunidade que permitia que as intervençôes encontrassem eco nos discursos tanto subjetivos como ideológicos e se ampliassem com a contribuição das relaçóes intertextuais, uma vez que formavam um mosaico cujas peças se encaixavam em interfaces multifacetadas. A prática da intertextualidade é um exercício rico e fecundo, quer se trate de diálogos entre obras de uma mesma natureza, como aqui a narrativa literária, quer entre gêneros muito diversos, como, por exemplo, aqueles que os jovens podem estabelecer (atualmente, entre os mitos e games). 


\subsection{Sobre o valor dos percursos coletivos de leitura literária}

Esses três exemplos têm em comum leituras de textos literários e sua discussão em grupo. Ou seja, a implicação dos leitores a partir do debate interpretativo, da emergência mais ou menos controlada das subjetividades. A experiência compartilhada de leitura e de debate acerca de um texto leva os participantes a se apropriar, de modo conjunto, de um repertório também compartilhado de textos. Dessa forma, o sentido do texto literário não se reduz a uma suposta intenção do autor, operando-se uma abertura para múltiplas interpretaçóes possíveis. Como explica Marlène Lebrun (20I3):

Ler é investir em um lugar de leitor, quer dizer, em um texto, é apropriar-se dele. $\mathrm{O}$ investimento e a apropriaçáo seráo facilitados pelo ato de trocar e compartilhar no interior da comunidade interpretativa constituída em sala de aula. A leitura torna-se entáo um prazer de gourmet, ainda mais apreciada por ser convival (p. 134).

Dos três exemplos, o que podemos destacar é o fato de que deixar emergir o sujeito-leitor fornece, sem dúvida, material rico para entender o potencial de um texto literário e vislumbrar do que se trata quando se fala em polissemia. Como diz Antonio Candido, em "O direito à literatura", são três as dimensôes da literatura: uma forma de conhecimento, uma construção estética e uma visão de mundo (Candido, 2004 [1988], p. 176). Entendemos que a forma de conhecimento refere-se ao leitor, à construção estética ao texto e à visão de mundo ao autor. Seria muito profícuo para o leitor em formação a possibilidade de vivenciar essas três dimensóes. Sabe-se, há muito, que isso não ocorre em sala de aula, sendo um discurso sobre a literatura o objeto que ocu- 
pa esse lugar de formação de leitor, justamente eliminando-se o texto, o leitor e as relaçóes que se estabelecem entre eles.

Considerando a instância do leitor como estruturante do texto, acionando, assim, o conceito de "leitor implícito" (Iser, 1996), desenha-se um leitor, inscrito no texto, que materializa um conjunto de pré-orientaçôes oferecidas como condiçôes de recepção para os leitores reais. Isso significa compreender a obra literária como constituída de lugares vazios, com blocos da trama interrompidos ou sucedidos por acontecimentos náo previsíveis, exigindo do leitor o esforço de encontrar a relação não formulada pelo texto, preenchendo, assim, essas lacunas. Por essa perspectiva, a leitura empírica se dá por meio de uma relação dialética entre a expectativa sobre o que vai acontecer e a memória e o registro daquilo que já aconteceu.

Então, ao mesmo tempo que é preciso considerar a emergência desse sujeito-leitor, estudante em formação, e a construçáo de sentidos, também se deve considerar a natureza do texto literário. Trata-se de um ato de extrema complexidade, como sintetiza Richard Marcello em seu relatório de qualificação:

O papel do leitor se configura como estrutura do texto, que representa um conjunto de visóes esquematizadas do mundo que visam a um ponto comum de referências constituídas com caráter instrucional, e como estrutura do ato, pois as referências e suas ausências ativam a imaginação, despertando a diversidade referencial das perspectivas e as reunindo sob um horizonte de sentidos que se amplia e se reduz ao longo do processo de leitura (Marcello, 2009, digitado). 


\subsection{Sobre o valor didático das leituras subjetivas}

A subjetividade do leitor sempre foi negada na escola, considerada um caminho muito "psicológico", muito individual, ao mesmo tempo que as leituras realizadas por gosto, fora da escola, sempre foram consideradas ilegítimas, sem valor para a formação do leitor, com toda a atenção voltada para o texto e para o que diziam dele os especialistas.

A exclusão, ou ao menos a marginalização, da subjetividade do leitor é habitualmente apresentada como uma condição de êxito na leitura literária escolar e universitária. Um exemplo, entre nós, tomado de um documento institucional recente: "Para construir uma interpretação, é necessário superar as reaçóes pessoais restritas e parciais, semeadas de erros, confusas em razão do jogo múltiplo das conotaçôes". Assim, por mais presentes e ativos que sejam, em toda experiência de leitura literária, os distúrbios, as emoçôes, os devaneios, as associaçóes de ideias ou mesmo vinculaçóes espontâneas, que têm suas raízes na personalidade profunda, na história pessoal, nas recordaçóes literárias ou lembranças de momentos vividos do indivíduo que lê, são considerados elementos parasitas que falseiam, embaçam e emaranham a recepção de uma obra a ponto de lançá-la para fora do campo da literatura (Langlade, 20I3, p. 25).

Com os estudos voltados à recepção e, posteriormente, ao sujeito-leitor, essa posição de negação da cultura do jovem não tem mais sua razão de ser, como temos defendido em várias de nossas pesquisas ao longo da última década. ${ }^{16}$

Os estudos provenientes da Educação têm contribuído para abrir novas fendas nessa pedagogia de especialista de texto, tra-

I6 Dissertaçôes e teses sob a orientação de Neide Luzia de Rezende podem ser acionadas pelo Banco de Teses da USP. http://www.teses.usp.br/ 
dicionalmente disseminada pelo livro didático. Contudo, o ensino de literatura na escola básica brasileira ${ }^{17}$ resiste e tem sido a retransmissáo daquilo que os licenciandos aprendem no ensino superior, e isso quer dizer basicamente o estudo do texto, a partir de parâmetros críticos há tempos estabelecidos. Annie Rouxel (Rezende e Oliveira, 2015) discorre sobre as trilhas formais previstas para o trabalho com o literário, percorridas com o apoio de ferramentas de análise, que deixam de fora os sujeitos-leitores e travam a interpretação, criticando essa abordagem formalista no ensino básico. Em geral, o que temos é um fantasma dessas trilhas: características de época que devem ser encontradas em fragmentos de romances e poemas, encaixados, a todo custo, em períodos estéticos.

Ora, assim como o ensino da língua, antes centrado em uma perspectiva metalinguística, o ensino da literatura tem sido, de modo quase exclusivo, o da metaleitura, realizada de maneira extremamente superficial. Como analisar um sistema linguístico sem o exercício da língua e como avaliar um texto literário sem a leitura dos textos? Essa problemática, embora pareça evidente no caso da literatura, não tem avançado na mesma proporçáo das propostas do ensino de língua, com a contribuição dos estudos das correntes linguísticas mais contemporâneas.

É hora, portanto, de trazermos a leitura do texto literário para o centro da aula e de desenvolvermos práticas diversas de leitura compartilhada, por meio das quais a apropriaçáo dos textos e a construçáo de representaçóes sociais e estéticas possam efetivamente acontecer. Para tanto, é necessário que se proceda a novas abordagens das obras literárias, respeitando-se, obviamente, os direitos do texto, mas considerando-se também os direitos do leitor (Tauveron, 20I3). Como aponta Max Butlen, muitos são os cami-

I7 Importante frisar que nosso campo de referências é a escola pública. 
nhos que podem ser percorridos nessa busca por um ensino de literatura que faça sentido para o leitor em formação:

Pistas pedagógicas fecundas foram abertas nesses últimos anos e se inscrevem num vasto campo de renovação da aprendizagem da leitura e do ensino da literatura, mesmo que ainda devam ser aprofundadas. Entre elas, quero citar a prática da intertextualidade, que se traduz didaticamente pela organização de leituras em redes, o debate interpretativo, os círculos de leitores - ambos susceptíveis de favorecer a emergência do sujeito leitor —, a leitura em voz alta (reconsiderada em suas funçôes escolares), o diário de leitura. Diretamente provenientes das pesquisas, essas proposiçóes serão certamente retrabalhadas, redefinidas, enriquecidas nos próximos anos. Sua eficácia dependerá essencialmente da associaçáo a uma pedagogia da compreensão, preocupada em ensinar as estratégias de leitura e ajudar os alunos a construírem os saberes culturais, cognitivos e metacognitivos indispensáveis para superar as dificuldades na leitura, no tratamento da informação e na realização de inferências tanto textuais quanto extratextuais (Bueno e Rezende, 20I5, p. 56I).

Contudo, para que essas novas práticas possam chegar à escola, o sujeito-leitor precisa ser considerado nos cursos de formação de professores, ou seja, os sujeitos e suas práticas de leitura precisam ter um espaço de escuta, para que tenham confiança naquilo que leem, segurança no que constroem como interpretação compartilhada em sala de aula e para que possam ousar quando se transformarem, eles mesmos, em mediadores das leituras de seus futuros estudantes. 


\section{Referências}

BARTHES, Roland. Sobre Racine. Trad. de Ivone Castilho Benedetti. São Paulo: Martins Fontes, 2008, pp. 185-2II.

BAUDELOT, Christian et al. Et pourtant ils lisent... Paris: Seuil, 1999.

BOURDIEU, Pierre. Coisas ditas. São Paulo: Brasiliense, I990.

BUENO, Belmira O. e REZENDE, Neide L. "Formador de leitores, formador de professores: a trajetória de Max Butlen”. Educ. Pesqui., São Paulo, v. 4I, n. 2, pp. 543-64, abr./jun. 2015.

CANDIDO, Antonio. Vários escritos. Rio de Janeiro: Ouro sobre Azul/São Paulo: Duas Cidades, 2004, pp. I69-9I.

ECO, Umberto. Sobre os espelhos e outros ensaios. São Paulo: Nova Fronteira, 1989 .

ISER, Wolfgang. $O$ ato da leitura: uma teoria do efeito estético. Trad. de Johannes Kretschmer. São Paulo: Editora 34, I996, vv. i e 2.

LANGLADE, Gérard. "O sujeito leitor, autor da singularidade da obra". In ROUXEL, Annie et al. (orgs.). Leitura subjetiva e ensino de literatura. Sáo Paulo: Alameda, 20I3.

LEBRUN, Marlène. "A emergência e o choque das subjetividades de leitores do maternal ao ensino médio graças ao espaço . interpretativo aberto pelos comitês de leitura”. In ROUXEL, Annie et al. (orgs.). Leitura subjetiva e ensino de literatura. São Paulo: Alameda, 2013.

MACHADO, Anna Rachel. O diário de leituras: a introdução de um novo instrumento na escola. São Paulo: Martins Fontes, 1998.

PAES, José Paulo. A aventura literária: ensaios sobre ficção e ficçôes. São Paulo: Companhia das Letras, 200I.

PETRUCCI, Armando. "Ler por ler: um futuro para a leitura”. In CAVALLO, Guglielmo e CHARTIER, Roger. História da leitura no mundo ocidental. São Paulo: Ática, I999, v. 2.

REZENDE, Neide Luzia e OLIVEIRA, Gabriela Rodella de. "Um sujeito leitor para a literatura na escola. Entrevista com Annie Rouxel". Revista Teias, v. I6, n. 4I, 2015. 
$\mathrm{e}$ "Entre a identificação e o distanciamento: práticas e impressôes de leitura ficcional dos jovens e o ensino de literatura”. Revista Diadorim, v. I8, n. I, 2016.

ROUXEL, Annie. "A tensão entre utilizar e interpretar na recepção de obras literárias em sala de aula: reflexão sobre uma inversão de valores ao longo da escolaridade". In et al. (orgs.). Leitura subjetiva e ensino de literatura. São Paulo: Alameda, 2013.

SUGAYAMA, Ariane Mieco. Múltiplas leituras: novas perspectivas teóricas e metodológicas para um letramento literário (tese). PUC-SP, 2017.

TAUVERON, Catherine. "Direitos do texto e direitos dos jovens leitores: um equilíbrio instável”. In ROUXEL, Annie et al. (orgs.). Leitura subjetiva e ensino de literatura. São Paulo: Alameda, 2013.

VERRIER, Jean. "Vãs querelas e verdadeiros objetivos do ensino da literatura na França”. Educação e Pesquisa, São Paulo, v. 33, n. 2, pp. 207-I3, maio/ ago. 2007. 


\title{
10 \\ Por uma poesia para a infầncia
}

\author{
Ninfa Parreiras
}

Sabemos, por meio da cultura clássica greco-romana, da qual herdamos a literatura, que os primeiros escritos literários foram feitos sob a forma poética, a exemplo de Ilíada e Odisseia, de Homero. Desse modo, o surgimento da poesia coincide com o da literatura.

A poesia não está presente somente nas produções clássicas e consideradas letradas, mas também nas produçôes de origem popular, como a literatura de cordel, os acalantos, as letras de cançôes da música popular brasileira, surgindo, muitas vezes, na contramão da cultura, como uma forma de protesto.
A ciência inteira
Acabava de concluir
Que o universo nunca
Parou de se expandir
Que seres extraterrestres
São inteligentes mestres
Que um dia hão de vir...
(Santa Helena, 2003, p. 5)

Nem tudo que está escrito em versos é poesia. Não bastam as estrofes e as rimas. É necessário algo mais, que vá além, que traga ritmo, melodia, tristeza ou riso, uma sonoridade própria. Uma nova linguagem que alguns poetas conseguem criar, uma língua visual e sonora. 
Afinando o violino

Todo Lino
Viofino
Toco vio
Fonolino
Vio toco
Linofino
Toco fino
Violino
(Caparelli, 2003, p. I06)

Os poemas têm uma linguagem sintetizada, aglutinada, híbrida e simbólica, como a do sonho. A criação poética e a criação onírica falam a língua de nosso inconsciente, as coisas de um mundo com sentidos pouco lógicos e racionais. A poesia também tem uma aproximaçáo com o sagrado, no sentido de ambos nos colocarem em contato com o sublime, o inexplicável.

Se Monteiro Lobato, em I922, com a obra $A$ menina do narizinho arrebitado (hoje publicada como Reinaçóes de Narizinho), inaugura uma obra em prosa com feiçóes nacionais e também povoada de fantasia, Cecília Meireles, em 1964, traz em Ou isto ou aquilo o que pode ser considerado a primeira obra em versos com o uso de ludicidade e de imaginação. O grande talento de Cecília é a quebra dos padróes morais. Seus poemas brincam com as palavras, com as coisas, com as formas, e fogem de ensinamentos.

Em primeiro lugar, vamos falar dos poetas que vieram antes dela. Henriqueta Lisboa, com seu $O$ menino poeta, de I943, faz um belo uso de metáforas e de imagens. Mas ainda não rompe com o compromisso moral e cívico, uma marca do final do século XIX (a exemplo de Olavo Bilac). 


\section{O menino poeta \\ não sei onde está. \\ Procuro daqui \\ Procuro de lá}

Tem olhos azuis

ou tem olhos negros?

Parece Jesus

ou índio guerreiro?

Tra-la-la-la-li

tra-la-la-la-la

Mas onde andará

que ainda não vi?

Nas águas de Lambari,

nos reinos do Canadá?

Estará no berço

brincando com os anjos,

na escola travesso

rabiscando bancos?

O vizinho ali

disse que acolá

existe um menino

com dó dos peixinhos.

Um pescou por pescar

um peixinho de âmbar

coberto de sal.

Depois o soltou [...]

(Lisboa, 2003, n.p.) 
Boa parte daquela produçáo provinha de encomenda ou tinha fins educacionais. $O$ menino poeta náo foi publicado por editora de livros didáticos nem trazia uma apresentação focada em escolas. Mantinha uma voz adulta voltada à infância, que, nos poemas de Henriqueta, ganham vigor estético.

Antes ainda, os poetas Gonçalves Dias e Casimiro de Abreu dedicaram poemas às crianças, incluídos em livros destinados a adultos. Vejam-se os versos de Gonçalves Dias:

\section{Canção do exílio}

Minha terra tem palmeiras,

Onde canta o Sabiá;

As aves, que aqui gorjeiam,

Não gorjeiam como lá.

Nosso céu tem mais estrelas,

Nossas várzeas têm mais flores,

Nossos bosques têm mais vida,

Nossa vida mais amores.

Em cismar, sozinho, à noite,

Mais prazer eu encontro lá;

Minha terra tem palmeiras,

Onde canta o Sabiá.

Minha terra tem primores,

Que tais não encontro eu cá;

Em cismar — sozinho, à noite -

Mais prazer eu encontro lá;

Minha terra tem palmeiras,

Onde canta o Sabiá. 
Não permita Deus que eu morra,

Sem que eu volte para lá;

Sem que desfrute os primores

Que não encontro por cá;

Sem qu'inda aviste as palmeiras,

Onde canta o Sabiá.

(Calcanhoto, 20I4, p. I2)

\section{E agora vejamos "A boneca", de Olavo Bilac:}

\section{A boneca}

Deixando a bola e a peteca,

Com que inda há pouco brincavam,

Por causa de uma boneca,

Duas meninas brigavam.

Dizia a primeira: "É minha!"

— "É minha!" a outra gritava;

E nenhuma se continha,

Nem a boneca largava.

Quem mais sofria (coitada!)

Era a boneca. Já tinha

Toda a roupa estraçalhada,

E amarrotada a carinha.

Tanto puxaram por ela,

Que a pobre rasgou-se ao meio,

Perdendo a estopa amarela

Que lhe formava o recheio.

E, ao fim de tanta fadiga, 
Voltando à bola e à peteca, Ambas, por causa da briga,

Ficaram sem a boneca...

(Calcanhoto, 20I4, p. 22)

De volta a Ou isto ou aquilo, observamos o uso de figuras de linguagem, como as metáforas, e elementos que caracterizam a presença de imagens, som e ritmo. Ao ler os poemas, vemos e sentimos as coisas mais simples das quais fala a poetisa: a rua, o colar, a bolha, a morte, a flor...

Jogo de bola

A bela bola

Rola:

A bela bola de Raul.

Bola amarela,

A da Arabela.

A do Raul,

Azul.

Rola a amarela

E pula a azul. [...]

(Meireles, 2004, n.p.)

Cecília propõe uma brincadeira de bolas, nomes e palavras. É o grande valor do poema: ser um brinquedo aos olhos de quem o lê. O leitor sente a bola e vê a imagem de Raul e de Arabela. São coisas aparentemente simples, mas de complexidade estética: uma bola que rola, outra que pula; uma azul, outra amarela... A autora 
retoma a beleza das coisas cotidianas e a importância do brinquedo. O poema, por si só, tem uma musicalidade gostosa. Há um deslocamento provocado pelo jogo sonoro das palavras.

A Arca de Noé, de Vinicius de Moraes, é uma obra clássica. Não por ser antiga, mas porque os poemas são vivos e ficaram no imaginário de muitas geraçóes. Vinicius capta, com sensibilidade, as características de cada animal, trabalha a sonoridade das palavras e dos bichos e das coisas que explora.

\section{A galinha-d'angola}

Coitada

Da galinha-

D'angola

Náo anda

Regulando

Da bola

Não pára

De comer

A matraca

E vive

A reclamar

Que está fraca:

- "Tou fraca! Tou fraca"

(Moraes, 2005, p. 37)

Em cada criação, o autor imprime uma marca de simplicidade e de musicalidade. Os versos cantam e ecoam o jogo de palavras. Versos lúdicos, cheios de ritmo e brincadeira. E ainda a presença do jogo, importante para a poesia, que flutua entre o ritmo e a imagem. Trata-se de algo fundamental para a criança, que encontra, no brinquedo e no jogo, uma ponte de comunicaçáo com o mundo. 
Nas décadas que se seguiram à obra de Vinicius, surgiram importantes autores de poesia para crianças e adolescentes: Sérgio Caparelli é um deles. Em sua obra III poemas para crianças, há uma reuniấo de poemas que recorrem ao cotidiano, aos bichos e ao tempo:

\section{Manhã}

O canto

Do galo

Abre as cortinas

Do dia.

(Caparelli, 2003, p. 134)

José Paulo Paes, além de sua obra para o público adulto, deixou-nos uma produção voltada às crianças. Em Um passarinho me contou, ele trabalha a lógica das coisas e o humor é a marca de seu trabalho:

\section{Metamorfose}

Me responda você

Que parece um sabichão:

Se lagarta vira borboleta

Por que trem não vira aviāo?

(Paes, 1996, n.p.)

Elias José, autor de literatura para a infância e a juventude, legou-nos uma obra diversificada com muitos livros de poemas. Em Disque poesia, dividido em cinco partes ("Para estes números: tecle"; "Animais: tecle"; "Gente: tecle"; "Tempo: tecle" e "Jogo de palavras: tecle"), o poeta brinca com a contemporaneidade e a ironiza: 
o teclar, o discar e o uso de aparelhos eletrônicos. Usa sonoridades e nonsense, e brinca com as palavras, os sentidos, os sons e as formas poéticas.

A caligrafia de Dona Sofia, de André Neves, é um belo tratado de poesia. O autor apresenta a história de uma personagem apaixonada pelos versos, uma professora aposentada bastante afetiva. Depois de encher as paredes de sua casa com poemas, ela passa a enviar cartóes aos moradores do local. E o que trazem? Poemas! Os versos de vários poetas nacionais e estrangeiros foram citados $\mathrm{e}$ desenhados. É um livro que corporifica a poesia. Mostra o movimento dos atos de fazer e ler poesia.

A arte dos versos é importante como expressão do corpo, dos movimentos. Ela habita o território do nonsense, do absurdo, do que não tem sentido, e isso nos potencializa, acompanhando nossa vida desde a infância. $\mathrm{O}$ bebê é embalado com cantigas que são pequenos poemas folclóricos, os acalantos. Isso faz parte da cultura de muitos países, em especial do Brasil, com uma herança folclórica diversificada, proveniente de povos que nos legaram tantas tradiçóes populares.

Mais tarde, cantigas de roda, trava-língua, quadrinhas, adivinhas, parlendas e outras modalidades de poemas da oralidade são transmitidas às crianças de pouca idade, ora na família, ora na escola. E até mesmo em espaços de socialização: na rua, nas praças e nas áreas de lazer.

Se isso não acontece na vida familiar, há uma perda para a criança em relaçáo ao contato com a musicalidade das palavras. E uma perda da afetividade que um adulto experimenta ao cantar, ao declamar versos para a infância. Os poemas transmitidos pela oralidade trazem o trabalho com as palavras, com peso para a musicalidade dos versos. Interessa brincar com sons e ritmos, o uso de nonsense e coisas irracionais, como uma vaca que toma guaraná de canudinho, um vampiro que gosta de açaí, e não de sangue. 
Seja lírico, seja bem-humorado, o poema transita em um território de fantasia e sonho. E quem vive sem isso?

Quando a criança vai para a escola, a poesia marca presença em atividades lúdicas, com a recitação de versos, cantigas etc. Há brincadeiras para os grupos de alunos, que lidam com as partes do corpo, o aparecer/desaparecer de objetos e seres. Sons de animais e de fatos da vida cotidiana marcam o emprego da onomatopeia, que muito agrada à criança.

À medida que ela vai crescendo, contudo, há certo distanciamento da poesia. Por que a poesia não faz parte das leituras das famílias? E por que os professores sentem dificuldade de ler poemas para e com as crianças? Adquirem-se muito mais livros em prosa do que em verso para as bibliotecas escolares. Além disso, são poucas as editoras que publicam poesia comercialmente. A maioria das editoras de literatura concentra sua produçáo em prosa: romances, novelas, contos, crônicas, ensaios etc. E a maioria dos prêmios literários se destina aos romances.

Se seguirmos oferecendo versos às crianças e aos adolescentes, de forma lúdica, sem cobrança, eles vão apreciar. Basta pensar na relação do jovem com o funk, o rap, o samba, o rock. Eles gostam do embalo, do ritmo e da melodia. Isso é importante para a consolidação dos valores identitários, como, por exemplo, a aceitação da mudança na voz, o corpo em crescimento, as alteraçôes na pele e no cabelo. Também é importante para se lidar com as diferenças entre as pessoas e as transformaçóes subjetivas que enfrentamos. A poesia (diferente da prosa) está mais ligada aos sentidos, às percepçóes, ao lado irracional e inconsciente.

Quando lemos os poemas de Fernando Pessoa e de seus heterônimos, experimentamos algo que nos conecta com os muitos eus que nos constituem. Para o adolescente, esse brincar de ser outra pessoa, o jogo de ser ora um, ora outro, é o jogo da própria vida, com suas contradiçóes e ambiguidades. Isso sem falar na 
importância do jogo e da brincadeira na vida de uma criança. Ela não viveria sem isso. É por meio do brinquedo que a criança se realiza como pessoa. $\mathrm{O}$ tocar, o experimentar, o fazer de conta são experiências que a poesia oferece ao adolescente e à criança.

Para escrever literatura, é necessário convocar a nossa criança. Simbolicamente, é ela quem solta a voz do escritor, que o conecta com a fantasia, o imaginário, o sonho. A escrita literária difere de outras porque nela há características de polissemia, verossimilhança, intertextualidade. Ela é lapidada, não se tratando de uma escritura bruta. Importam a musicalidade, o ritmo, as figuras de linguagem (em especial, as metáforas e as metonímias). O texto náo é linear; ele atrai o leitor pela forma, e não pelos conteúdos e assuntos.

A poesia, em especial, é rica em imagens, sonoridades e nonsenses, ou seja, é uma livre associação de ideias, desprovidas de ligaçáo semântica ou conceitual. A poesia é uma dança de palavras.

Sigmund Freud (1856-1939), o pai da psicanálise, comparou o poeta à criança. Em um importante trabalho de 1907-8, registra:

Escritores criativos e devaneios:

$\mathrm{O}$ escritor criativo faz o mesmo que a criança que brinca. Cria um mundo de fantasia que ele leva muito a sério, isto é, no qual investe uma grande quantidade de emoção, enquanto mantém uma separação nítida entre o mesmo e a realidade. [...] A irrealidade do mundo imaginativo do escritor tem, porém, conseqüências importantes para a técnica de sua arte, pois muita coisa que, se fosse real, não causaria prazer, pode proporcioná-lo como jogo de fantasia, e muitos excitamentos que em si são realmente penosos, podem tornar-se uma fonte de prazer para os ouvintes e espectadores na representação da obra de um escritor (p. I50). 
A origem da poesia se aproxima do nascimento da própria linguagem. E para que serve essa arte milenar? Na vida recheada de competição, tecnologia, agilidade nas comunicaçóes, o que leva a poesia a sobreviver? Ela precisa ser lida, declamada. Por que, então, a poesia ainda? Porque ela é alimento. Alento. A poesia nos acolhe em um mundo que valoriza a produçáo, os números, as aparências. E nos faz olhar para dentro, fazendo-nos calar. Traz um silêncio que nos provoca a associação de imagens e de ideias.

Poética é a arte que estuda a poesia e suas obras, considerando o que elas têm de específico, aquilo que lhes é próprio: o poético, o qual, por sua vez, é constituído dos elementos fundamentais do poema. O poético é a matéria da poesia, é tudo de que ela pode falar e o modo como fala em um poema. $\mathrm{O}$ objeto inventado pela poesia é o poema, de modo que este vem a ser um artefato, o produto acabado que resulta do fazer artístico. Poema é a obra de arte verbal realizada concretamente.

Ezra Pound (I882-I972), poeta norte-americano, ensinou-nos que existem três elementos fundamentais que podem caracterizar a arte dos versos: a melopeia (o som), a fanopeia (as imagens) e a logopeia (as ideias). Quando a criança escuta um poema, conecta-se, principalmente, com a sonoridade (os sons) e as ideias (fantasias). Os adolescentes e os adultos se conectam com os três elementos apontados por Pound.

No Brasil, temos uma equipe valiosa de poetas que escreveram para crianças: Henriqueta Lisboa, Cecília Meireles, Vinicius de Moraes, José Paulo Paes, Elias José, Sérgio Caparelli, Roseana Murray, Leo Cunha, entre tantos outros. E há ainda os poetas consagrados que nos deixaram um reconhecido acervo também para a infância: Carlos Drummond de Andrade, Ferreira Gullar, Mário Quintana, Manuel Bandeira, Manoel de Barros. Suas obras são alimento para todos nós, que criamos e trabalhamos com língua e literatura. $\mathrm{Ou}$ tros tantos poetas escreveram e eternizaram a poesia: Olavo Bilac, 
Castro Alves, Casimiro de Abreu, João Cabral de Melo Neto, Adélia Prado, Cora Coralina, para citar alguns.

Quando escrevemos em versos, não devemos pensar em um leitor, nem em uma coisa específica. Deve-se deixar sair livremente as palavras que chegam, a partir de uma foto, de uma cena, de um ruído fotografado com os sentidos. Em seguida, deve-se fazer uma releitura, passar a limpo, cortar ou substituir palavras. Passado um tempo, outra leitura novamente, agora em voz alta. A familiaridade da poesia com a música precisa ser preservada. Por isso, ao ler poesia, não precisamos entender os poemas, mas sentir os versos.

A obra organizada pelo poeta Leo Cunha, Poesia para crianças, conceitos, tendências e práticas, reúne seis artigos de cinco autores sobre a poesia para a infância. O livro traz capítulos autônomos que podem ser lidos separadamente, mas que abordam conteúdos que estão relacionados à poesia na vida da criança. Logo, um capítulo pode completar outro.

A poetisa Ângela Leite de Souza abre o primeiro capítulo com uma reflexão sobre os conceitos de poesia, poético e infantil. Isso pode ser esclarecedor para os professores e educadores, e instigar uma reflexão sobre o fazer poético.

No segundo capítulo, o poeta e professor Carlos Augusto Novais nos dá uma aula sobre aspectos da arte dos versos, como rima, métrica e figuras de linguagem, os elementos constitutivos de um poema. Assim, esclarece o que caracteriza a poesia e a distingue da prosa.

O terceiro capítulo, a cargo do organizador da obra, o escritor Leo Cunha, aborda as dificuldades do livro de poesia no mercado editorial brasileiro. Leo ainda tece comentários sobre as principais manifestaçóes poéticas presentes na produção de nosso país. E indaga: Por que é difícil publicar textos em versos? Como a escola é a grande compradora de livros para a infância e a juventude, existem certos 
obstáculos no trabalho com os versos. Isso porque, com frequência, espera-se que o aluno entenda e interprete o poema, o que se revela uma tarefa quase impossível. A poesia não serve para isso, mas para ser desfrutada sem muitas explicaçóes.

O Capítulo 4, assinado pela poetisa Glaucia de Souza, traz algumas atividades a serem realizadas em sala de aula. Souza defende três pilares para o trabalho: percepção, discussão e criação. $\mathrm{Ou}$ seja, a poesia não é para ser interpretada, mas para ser vivida com leitura e sensibilidade.

Os dois últimos capítulos, de autoria da professora Maria Antonieta Cunha, trazem um olhar sobre a prática. Por um lado, ela propóe alternativas para o professor aprofundar a relação com o texto poético. Por outro, apresenta critérios para se selecionarem as obras de poesia. Não são as rimas que unicamente caracterizam a poesia. Escolher um livro de poemas demanda reconhecer, nos versos, as imagens, os sons e um rol de associaçóes sensitivas.

A primeira obra publicada exclusivamente sobre poesia infantil de uma estudiosa brasileira de que temos notícia é Poesia infantil, da professora gaúcha Maria da Glória Bordini, publicada em 1986. Sucinto, o livro introduz o leitor no mundo da poesia para a infância. Foi uma referência para estudantes de Letras e Pedagogia por muito tempo, bem como para professores, educadores e mediadores de leitura, além de escritores e poetas.

Em 2002, foi publicado o livro Poesia infantil: o abraço mágico, da catarinense Eloí Elisabete Bocheco. Com menos divulgação, infelizmente, essa obra não se tornou tão conhecida nem no meio acadêmico, nem no meio escolar. Sua leitura é válida por se tratar de obra de referência na área da poesia infantil, ao colocá-la no patamar de reconhecimento da prosa. Também em 2002, tivemos a publicaçáo $A$ poesia na escola: leitura e análise de poesia para crianças, livro organizado por Ana Elvira Gebara. O destaque des- 
sa obra é o estudo feito sobre a obra do poeta José Paulo Paes, que nos deixou poemas de qualidade estética para a infância.

Em seguida, em 2003, o poeta mineiro Elias José publicou $A$ poesia pede passagem: um guia para levar a poesia às escolas. Com muita afinidade com a poesia, uma vez que Elias publicou dezenas de livros com poemas para crianças, jovens e adultos, sua obra transita com informalidade na escola. Derruba certos padrôes, como, por exemplo, o de utilizar a poesia para ensinar gramática, e propóe o uso menos didático dos versos. Na cidade onde Elias morou, Guaxupé, foi criado o Instituto Cultural Elias José, por Silvia Monteiro (sua viúva). Trata-se de um espaço aberto para receber escolas, grupos e desenvolver atividades de leitura voltadas a crianças. Assim, a poesia desse consagrado autor, falecido em 2008, continuará a ser lida e conhecida por muitas geraçóes.

Em 2007, o professor Hélder Pinheiro sistematizou, em Poesia na sala de aula, uma série de sugestôes de atividades com os versos, de jogos dramáticos a varais poéticos.

Neusa Sorrenti, compositora e poetisa, publicou, em 2010, $A$ poesia vai à escola: reflexöes, comentários e dicas de atividades, obra com reflexões e sugestões para o trabalho com versos na escola.

Em 20II, Gloria Kirinus publicou Synthomas de poesia na infância. Nessa obra, a criatividade da criança, tão comprometida na contemporaneidade, é discutida pela autora, que propóe a poesia para aguçar o senso de sensibilidade e de criação na infância.

Com isso, percebemos que a poesia foi abordada, pontualmente, em alguns livros de referência, ao passo que existem centenas de livros que discutem a prosa destinada a crianças. Com certa dificuldade, temos um livro dedicado exclusivamente a esse gênero. Nesse contexto, a obra organizada por Leo Cunha representa um marco na história da literatura infantil brasileira. Vencedora do Prêmio de Livro Teórico da Fundação Nacional do Livro Infantil 
e Juvenil (FNLIJ) em 20I3, essa obra foi adquirida pelo governo federal para o PNBE do Professor 2013, sendo distribuída nas escolas públicas de todo o país.

Sem dúvida, precisamos de estudos de e sobre poesia infantil que possam ser publicados e divulgados nas escolas e nas instituiçóes educacionais e culturais, bem como às famílias. Além disso, é preciso que os estudos acadêmicos possam igualmente ser conhecidos pelos profissionais que lidam com as crianças. Afinal, a poesia traz possibilidades de entretenimento, de jogo, de associaçóes e de contato com o não explicável, com o não racional que caracteriza nossa vida.

Em relação à poesia lida e escrita pelo adolescente e pelo jovem, observamos amplo interesse desses grupos pela poesia marginal que despontou nos anos 1970 e que está sendo revitalizada na contemporaneidade.

O mimeógrafo era uma espécie de impressora que usava papel estêncil e álcool para reproduzir as cópias. Isso ficava mais em conta do que publicar um livro em gráfica, além de traduzir um sentimento de contramão da cultura, do fazer artesanal, transgressor. Algo avesso ao capitalismo selvagem e ao autoritarismo, que já caracterizavam aqueles tempos. Assim, os poetas criavam seus livros manualmente e os vendiam, de mão em mão. Essa poesia nasceu na rua, nas praças, na PUC-Rio, no Baixo Leblon, nos bares. No Rio de Janeiro e em muitas outras cidades. Cada livro feito à mão era impresso em poucas cópias. Foi um movimento que trazia a língua falada, a informalidade, o pensamento não organizado para a poesia. Do Rio de Janeiro, podemos citar Ricardo Chacal e Ana Cristina Cesar. De Minas Gerais, Cacaso e Francisco Alvim. Em seguida, vieram poetas de outras partes do país, como, por exemplo, Paulo Leminski, de Curitiba.

Ana Cristina Cesar chegou com uma intimidade surpreendente a esse cenário. Era a Ana Cristina C, um nome muito carioca. 
Parece que estamos no quarto com ela lendo os poemas, as cartas, os diários. Temos a impressão de que há uma narrativa por trás de cada poema. É tudo bem simples, um entrar nos rascunhos, no fazer, algo na pele do papel, no esqueleto da tinta e do lápis. E também certo atrevimento com a escrita:

\author{
(sem titulo) \\ Quando entre nós só havia \\ uma carta certa \\ a correspondência \\ completa \\ o trem os trilhos \\ a janela aberta \\ uma certa paisagem \\ sem pedras ou \\ sobressaltos \\ meu salto alto \\ em equilíbrio [...] \\ (Cacaso et al., 2006, p. 2I)
}

Ana Cristina escrevia coisas que imaginamos pensadas, e não escritas. Nossos sentimentos ficam traduzidos ali, sem conjunçóes. A identidade, o acaso, a tentativa de um descobrir-se. Veio, entâo, Cacaso, de Minas Gerais, com algo peculiar às lembranças. Brincava com os sons, com a polissemia, com delicadeza poética. Um desdobrar-se em segredos e intimidades, sentimentos que náo damos conta de entender. Sua vida foi breve como sua poesia. Ela expunha uma memória afetiva em seus versos. Amor e humor juntos. Um sopro lírico: 
(sem título)

Se o porco é espinho

caço e asso

se o corpo é sozinho

traço e passo

(Cacaso et al., 2006, p. 22)

E o Leminski? Sua poesia trazia formas concisas, a precisão. E desenhos, imagens feitas com/de palavras:

(sem titulo)

aqui

nesta pedra

alguém sentou

olhando o mar

o mar

não parou

pra ser olhado

(Leminski, 20I4, n.p.)

De vocabulário comum, parecia ir fundo no avesso e na roupagem das palavras: as novas e as velhas. Revestia-as de beleza sonora, de um sem-número de sentidos. Irreverência e surpresa a cada verso. A poesia dele renasce a cada leitura.

Após, veio Francisco Alvim. Seus versos traçavam um painel da sociedade da época. Um brincar com palavras. Um falar, desfalar, desfolhar, pelo olhar lírico: 


\author{
Discordância \\ Dizem que quem cala consente \\ eu por mim \\ quando calo dissinto \\ quando falo minto \\ (Cacaso et al., 2006, p. 49)
}

Com o Chacal, chega uma poesia irônica, irreverente e pop. Seus versos chegam a desconcertar o leitor, com uma velocidade musical que fala da poesia associada às coisas mais banais.

\author{
Rápido e rasteiro \\ vai ter uma festa \\ que eu vou dançar \\ até o sapato pedir pra parar. \\ aí eu paro, tiro o sapato \\ e danço o resto da vida \\ (Chacal, 2007, p. 353)
}

Chacal é imortal. Criou e organizou saraus e vários movimentos com a poesia no Rio e pelo Brasil, como, por exemplo, CEP 20.000 e Nuvem Cigana. Organizou revistas e tem lutado pela poesia, com a poesia. Escreveu muitos poemas para leitores de todas as idades. Sua criação poética pedala, brinca e passeia por objetos, ruas, pessoas, acontecimentos... Ele costuma tomar um acontecimento cotidiano e transformar a experiência em poesia, questionando a nossa existência: 


\section{Meio assim}

tava atrasado.

o metrô ia sair.

corri.

a porta se fechou.

metade de mim foi.

outra ficou.

uma que já era,

ficou mais ensimesmada.

olhando o relógio.

falando no celular.

a outra, tagarela,

levantava leviana

a saia das moças,

uivando intempestiva. [...]

(Chacal, 20I2, p. 28)

As redes sociais, a política, um dia bonito de sol, até mesmo o Facebook, tudo isso está em seus versos. O poeta brinca, faz pensar. Cutuca o que parece ser aceito pelos padróes convencionais. A informalidade, a musicalidade, as gírias, a escrita feita como a fala, o uso de minúsculas, as abreviaçôes: vc. Uma reprodução direta da fala, sem exageros ou rebuscamentos. Uma poesia na contraordem: a letra minúscula para iniciar o verso.

$\mathrm{Na}$ atualidade, o rap e os saraus de poesia/música têm movimentado bastante a expressão cultural dos jovens. Assim, eles postam versos nas redes sociais, apresentam-se em eventos abertos ao público, com desafios (palavras/temas), e escrevem em letras minúsculas, com bastante informalidade, na língua coloquial. 
As coisas que importam são a sonoridade, o ritmo e a cadência presentes nos versos. O protesto, a opção por uma vida simples e um olhar sobre grupos minoritários caracterizam essa criação tão intimista que está em curso nos colégios e nas faculdades. Seguem alguns versos náo publicados em livro, mas postados no Facebook:

\author{
fui escrever pro noticiário \\ mas tinha papel não \\ de um salário precisava \\ eu não tinha papeláo \\ ter arma não te faz bandido \\ só te faz mais um réu \\ vejo muitos querendo isso \\ sem precisar, tu já tem papel... \\ a condição de vida condiciona \\ muitos, outros condicionados \\ a ser cópias apenas \\ somos seres sem lógica \\ ar-condicionado do busão parece europa \\ sem síndrome de vira lata, amo meu país \\ tem uns virando lata e não respeita raiz \\ não sabe viver, troca de fase \\ a vida não é um jogo, mas quem sabe jogar \\ cresce tipo metástase \\ de dia corrigindo minhas frases \\ não sei onde tem crase \\ entenda: cópia não é paráfrase \\ diariamente vivendo o horror \\ tenho um diário na minha mente, isso me causa dor \\ arranjo problemas semanalmente e náo sei o causador
}


toda semana ela mente, sinto pena do namorado me ajuda, doutor, a dor não para de me namorar eu sou namorador, sô namorador, sô... (Ícaro Parreiras, não publicado)

A linguagem mágica e o despojamento das palavras na poesia contemporânea retomam os ideais de busca de liberdade e de protesto aos padróes impostos de décadas atrás. Os versos mostram o avesso, debocham da realidade e reinventam formas de existência que valorizam a subjetividade, além de reforçarem o valor da literatura como arte das palavras. O espaço da poesia como expressão lúdica da fantasia, como corpo de contestação e de transgressão aos padrôes normativos. A poesia sobrevive ao capitalismo, ao descarte exacerbado dos bens de consumo, permanecendo como uma arte a ser reinventada na esquina, na praça, na escola, em casa. A arte das palavras e dos sons.

\section{Referências}

BOCHECO, Eloí Elisabete. Poesia infantil: o abraço mágico. Chapecó: Argos, 2002.

BORDINI, Maria da Glória. Poesia infantil. São Paulo: Ática, 1986.

CACASO et al. Poesia marginal. São Paulo: Ática, 2006, v. 39. (Para gostar de ler).

CALCANHOTTO, Adriana. Antologia ilustrada da poesia brasileira para crianças de qualquer idade. Ilustraçōes da autora. Rio de Janeiro: Ediçōes de Janeiro, 2014.

CAPARELLI, Sérgio. III poemas para crianças. Ilustraçôes de Ana Gruszynski. Porto Alegre: L\&PM, 2003.

CHACAL. Belvedere. Sáo Paulo: CosacNaify, 2007. . Murundum. São Paulo: Companhia das Letrinhas, 2012.

CUNHA, Leo (org.). Poesia para crianças, conceitos, tendências e práticas. Curitiba: Piá, 2012. 
FREUD, Sigmund. "Escritores criativos e devaneios". In Obras psicológicas. Rio de Janeiro: Imago, I988, v. IX.

GEBARA, Ana Elvira (org.). A poesia na escola: leitura e análise de poesia para crianças. Sáo Paulo: Cortez, 2002.

JOSÉ, Elias. A poesia pede passagem: um guia para levar a poesia às escolas. São Paulo: Paulus, 2003.

. Disque poesia. Ilustraçóes de Angelo Abu. Belo Horizonte: Compor, 2008.

KIRINUS, Gloria. Synthomas de poesia na infância. São Paulo: Paulinas, 201 .

LEMINSKI, Paulo. O bicho alfabeto. Companhia das Letrinhas, 2014.

LISBOA, Henriqueta. O menino poeta. São Paulo: Global, 2003.

LOBATO, José Bento Monteiro. Reinações de Narizinho. Ilustrações de Manoel Victor Filho. São Paulo: Brasiliense, I989.

MEIRELES, Cecília. Ou isto ou aquilo. Ilustraçóes de Thaís Linhares. Rio de Janeiro: Nova Fronteira, 2002.

MORAES, Vinícius de. A Arca de Noé. Ilustrações de Nelson Cruz. São Paulo: Companhia das Letrinhas, 2004.

MURALHA, Sidônio. A televisão da bicharada. Ilustrações de Fernando Lemos. Rio de Janeiro: Nórdica, 1962.

NEVES, André. A caligrafia de Dona Sofia. Ilustraçóes de André Neves. São Paulo: Paulinas, 2006.

PAES, José Paulo. Um passarinho me contou. Ilustraçôes de Kiko Farkas. São Paulo: Ática, I996.

PARREIRAS, Ícaro. Poema não publicado. Disponível em: https://www.facebook.com/icaro.guimaraes.56. Acesso em II jul. 2017.

PINHEIRO, Hélder. Poesia na sala de aula. Campina Grande: Bagagem, 2007. POUND, Ezra. $O A B C$ da literatura. São Paulo: Cultrix, I970. . A arte da poesia; ensaios escolhidos. São Paulo: Cultrix, I988.

SANTA HELENA, Raimundo. O menino que viajou num cometa. Xilogravuras de Erivaldo. Rio de Janeiro: Entrelinhas, 2003.

SORRENTI, Neusa. A poesia vai à escola: reflexóes, comentários e dicas de atividades. Belo Horizonte: Autêntica, 2010. 


\section{Sobre os autores}

\section{Aline Santos Costa}

Doutora em Educação pelo Programa de Pós-Graduação em Educação/ProPEd, da Universidade do Estado do Rio de Janeiro (UERJ). Desenvolve pesquisas sobre história da literatura infantil e história da formação de leitores no Brasil, com ênfase no período republicano pós-I930. Integra o grupo de pesquisa "Infância, Juventude, Leitura, Escrita e Educação" (GRUPEEL) e o "Grupo de Estudos Interdisciplinares em Educação: História e Memória” (MNEMOS).

\section{Célia Regina Delácio Fernandes}

Doutora em Teoria e História Literária (2004) pela Universidade Estadual de Campinas (UNICAMP) e Pós-Doutora em Letras (2016) pela Universidade Estadual de Maringá (UEM). Professora associada da Universidade Federal da Grande Dourados (UFGD), onde atua como docente da graduação e do programa de pós-graduação em Letras. Líder do grupo de pesquisa "Centro de Estudos em Ensino, Leitura, Literatura e Escrita" (CEELLE) da UFGD. 


\section{Cíntia Borges de Almeida}

Doutora em Educação pelo Programa de Pós-Graduação em Educação/ProPEd, da Universidade do Rio de Janeiro (UERJ). Atualmente, é professora dos cursos de Pedagogia e História da Faculdade de Belford Roxo e professora da Prefeitura do Rio de Janeiro. Pesquisadora Capes, desenvolve pesquisas em História da Educação e integra o grupo de pesquisa “Infância, Juventude, Leitura, Escrita e Educação” (GRUPEEL).

\section{Estela Natalina Mantovani Bertoletti}

Professora adjunta da Universidade Estadual de Mato Grosso do Sul (UEMS). Mestre e doutora em Educação pela Universidade Estadual Paulista (Unesp). Pós-doutorado em Educação Escolar pela Unesp e pós-doutorado em Educação pela Universidade do Estado do Rio de Janeiro (UERJ). Coordenadora do "Grupo de Estudos e Pesquisas em História e Historiografia da Educação Brasileira”, junto com o professor Ademilson Batista Paes.

\section{Fernando Rodrigues de Oliveira}

Professor adjunto da Escola de Filosofia, Letras e Ciências Humanas da Universidade Federal de São Paulo (Unifesp). Mestre e doutor em Educação pela Unesp, Marília; Graduado em Letras pela Faculdade da Alta Paulista e graduado em Pedagogia também pela Unesp, Marília. Integrante dos grupos de pesquisa "História do Ensino de Língua e Literatura no Brasil" e "Alfabetização no Brasil: estado do conhecimento".

\section{Flavia Ferreira de Paula}

Mestre em Letras e graduada em Letras pela Universidade Federal da Grande Dourados (UFGD). Atualmente é doutoranda em Linguística Aplicada pela Universidade Federal de Minas Gerais (UFMG). Membro do grupo de pesquisa "Centro de Estudos em Ensino, Leitura, Literatura e Escrita” (CEELLE) da UFGD. 


\section{Gabriela Rodella de Oliveira}

Professora adjunta da Universidade Federal do Sul da Bahia (UFSB). Mestre e doutora em Educação pela Universidade de São Paulo (USP). Vice-líder do grupo de pesquisa "Linguagens na Educação" (FE, USP).

\section{Márcia Cabral da Silva}

Professora associada da Universidade do Estado do Rio de Janeiro (UERJ). Mestre em Educação pela Pontifícia Universidade Católica do Rio de Janeiro e doutora em Teoria e História Literária pela Universidade Estadual de Campinas (Unicamp). Coordena o grupo de pesquisa "Infância, Juventude, Leitura, Escrita e Educação” (GRUPEEL).

\section{Maria do Rosário Longo Mortatti}

Professora titular da Universidade Estadual Paulista (Unesp). Graduada em Letras (FFCL Araraquara), mestre e doutora em Educação (Unicamp). Atua no curso de Pedagogia e no Programa de Pós-Graduação em Educação da Unesp, Marília. É coordenadora do grupo de pesquisa "História do Ensino de Língua e Literatura no Brasil”. Presidente emérita da Associação Brasileira de Alfabetização.

\section{Mirian Hisae Yaegashi Zappone}

Professora associada do Departamento de Teorias Linguísticas e Literárias e do Programa de Pós-Graduação em Letras da Universidade Estadual de Maringá. Doutorado em Literatura e outras manifestaçóes culturais pela Universidade Estadual de Campinas. Atualmente, realiza estágio de pós-doutorado na Universidade de Brasília, sob a supervisão da Profa. Dra. Regina Dalcastagnè. 


\section{Neide Luzia de Rezende}

Professora da Universidade de São Paulo (USP). Mestre em Letras (Teoria Literária e Literatura Comparada) e doutora em Educação pela USP. No programa de pós-graduação da Faculdade de Educação (USP), coordena o grupo de pesquisa "Linguagens na Educação”.

\section{Ninfa Parreiras}

Mestre em Literatura Comparada (USP), graduada em Letras e Psicologia (PUC-Rio), psicanalista titular da Sociedade de Psicanálise Iracy Doyle, escritora de obras literárias e de ensaios, pesquisadora e curadora dos eventos: Festa Literária de Santa Teresa (Flist), Poesia no Parque/Poesia no Castelo. Professora do Centro Educacional Anísio Teixeira (Ceat), da Estação das Letras e de cursos de literatura para professores da Secretaria Municipal de Educação - RJ.

\section{Patrícia Corsino}

Professora da Faculdade de Educação e do Programa de Pós-Graduação em Educação da UFRJ. Integra a linha de pesquisa “Currículo, Docência e Linguagem”, desenvolvendo pesquisa nos campos da infância, linguagem, alfabetização, leitura, escrita e literatura infantil.

\section{Vivianny Bessáo de Assis}

Professora adjunta do curso de Pedagogia da Universidade Federal de Mato Grosso do Sul (UFMS), campus de Naviraí (MS). Doutora em Educação pela Faculdade de Filosofia e Ciências (FFC) da Universidade Estadual Paulista (Unesp), campus de Marília (SP). Mestre em Letras pela Universidade Federal de Mato Grosso do Sul (UFMS), campus de Três Lagoas (MS), e graduada em Pedagogia pela mesma universidade. Integrante, desde 20I2, do grupo de pesquisa "História do Ensino de Língua e Literatura no Brasil”. 


\section{Série Pesquisa em Educação}

Políticas de integração curricular

Alice Casimiro Lopes

A formação de professores no Brasil: de 1996 a 2006 Henrique Garcia Sobreira

Discursos, tecnologias, educação

Raquel Goulart Barreto

Memórias e patrimônios: experiências em formação de professores

Carmen Lúcia Vidal Pérez

Maria Tereza Goudard Tavares

Mairce da Silva Araújo

Uma história da formação do leitor no Brasil

Márcia Cabral da Silva

Etnografia e educação: relatos de pesquisa

Carmen Lúcia Guimarães de Mattos

Helena Amaral da Fontoura 
Sentidos da cidadania: políticas de educação de jovens e adultos

Marcia Soares de Alvarenga

Percepção transdisciplinar - uma construção coletiva Organização: Elza Neffa e Antonio Carlos de Azevedo Ritto

Inclusão escolar de alunos com necessidades especiais Organização: Rosana Glat e Marcia Denise Pletsch

A metamorfose do trabalho docente no ensino superior: entre $o$

público e o mercantil

Maria Emília Pereira da Silva

Leitura, pesquisa e ensino

Márcia Cabral da Silva 